UNIVERSIDADE DE BRASÍLIA

FACULDADE DE EDUCAÇÃO

PROGRAMA DE PÓS-GRADUAÇÃO EM EDUCAÇÃO

LUCIANA CARVALHO CARRILHO

TRAJETÓRIAS ANIMADAS NA FORMAÇÃO DO PENSAMENTO CONCEITUAL NO ENSINO DE CIÊNCIAS

BRASÍLIA 
Ficha catalográfica elaborada automaticamente, com os dados fornecidos pelo(a) autor(a)

CARRILHO, Luciana Carvalho

Trajetórias animadas na formaçăo do pensamento conceitual no Ensino de Ciências / Luciana Carvalho CARRILHO; orientador Maria Helena da Silva CARNEIRO. - - Brasília, 2015.

$246 \mathrm{p}$.

Tese (Doutorado - Doutorado em Educaçå) - Universidade de Brasília, 2015.

1. Desenho Animado. 2. Ecossistema. 3. Ensino de Ciências . 4. Formação de conceito. 5. Vigotski. I. CARNEIRo, Maria Helena da Silva, orient. II. Título. 


\title{
TRAJETÓRIAS ANIMADAS NA FORMAÇÃO DO PENSAMENTO CONCEITUAL NO ENSINO DE CIÊNCIAS
}

\begin{abstract}
Tese de Doutorado apresentada à banca examinadora da Faculdade de Educação da Universidade de Brasília, sob a orientação da Prof $^{a}$. Dr ${ }^{\mathrm{a}}$. Maria Helena da Silva Carneiro, como requisito parcial para a obtenção do título de Doutora em Educação, na Área de Concentração de Educação em Ciências e Matemática na linha de pesquisa de Processos de Ensino e Aprendizagem dos Conhecimentos Científicos e Tecnológicos.
\end{abstract}




\section{TRAJETÓRIAS ANIMADAS NA FORMAÇÃO DO PENSAMENTO CONCEITUAL NO ENSINO DE CIENAIAS}

Tese de Doutorado apresentada à banca examinadora da Faculdade de Educação da Universidade de Brasília, sob a orientação da Profa. Dra. Maria Helena da Silva Carneiro, como requisito parcial para a obtenção do título de Doutora em Educação, na Área de Concentração de Educação em Ciências e Matemática na linha de pesquisa de Processos de Ensino e Aprendizagem dos Conhecimentos Científicos e Tecnológicos.

BANCA EXAMINADORA:

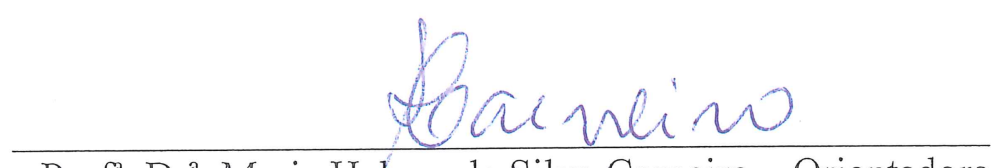

Prof ${ }^{\mathrm{a}}$. Dr ${ }^{\mathrm{a}}$. Maria Helena da Silva Carneiro - Orientadora

Universidade de Brasília

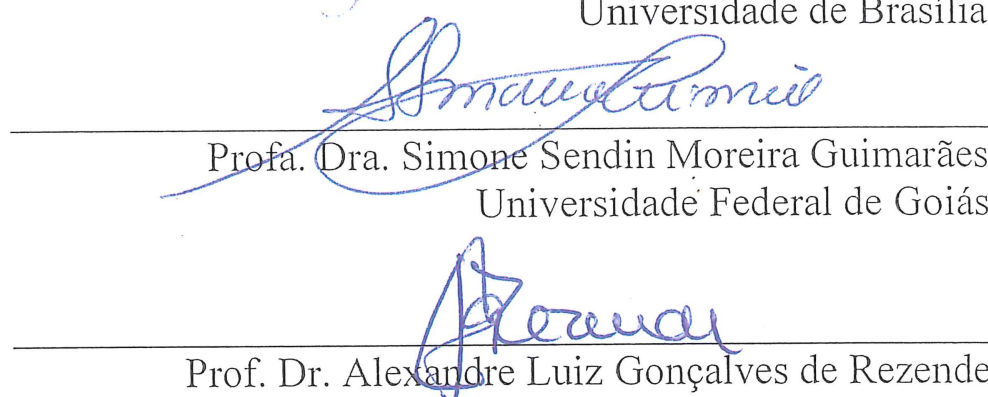

Universidade de Brasília

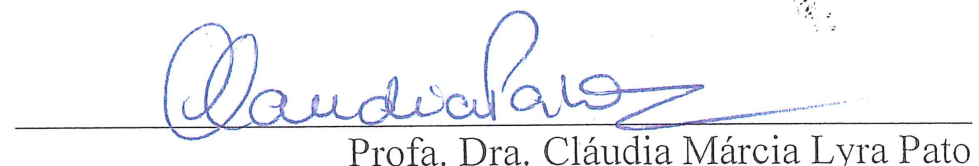

Universidade de Brasília

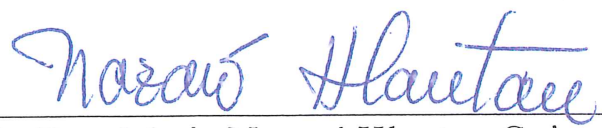

Profa. Dra. Maria Nazaré Klautau Guimarães

Universidade de Brasília

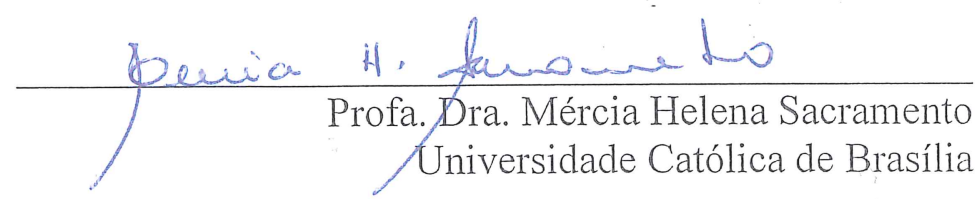


Às minhas pequenas bailarinas, Larissa e Valentina, amores de minha vida que, com seus sorrisos e gargalhadas, deixam nossos dias mais felizes. 
"O pensamento não apenas se expressa em palavras; ele adquire existência através delas".

Lev S. Vigotski 


\section{AGRADECIMENTOS}

Na minha vida, tudo é com emoção e, para torná-la ainda mais animada, tive uma gravidez inesperada no meio do doutorado e um parto atípico (a bolsa havia estourado e a Valentina nasceu no apartamento).

O título "Trajetórias animadas...” justifica-se não só pela pesquisa realizada, mas também por esses momentos únicos que tornaram o trabalho mais desafiante! Por isso, neste momento, gostaria de agradecer as pessoas que contribuíram, direta e indiretamente, para a concretização do trabalho.

Tudo posso naquele que me fortalece: agradeço a Deus, pelas bênçãos concedidas e pela minha saúde.

Aos amores incondicionais: meu esposo, Renato, pela compreensão e pelo apoio, e minhas lindas filhas, Larissa e Valentina, presentes de Deus. Amo vocês!

Ao meu porto seguro: minha família - pais, irmãos, sogros, cunhadas e familiares pelo carinho e incentivo em todos os momentos e também pelas comidinhas e pelos almoços reconfortantes nos fins de semana. Em especial, à minha mãe, que atendia prontamente aos meus pedidos de socorro, e aos meus sobrinhos, meus primeiros sujeitos de pesquisa (risos)! Beijocas estraladas!

À minha fortaleza, Maria Helena, pela força, pela confiança, pela paciência e pelo incentivo no decorrer da orientação do trabalho e por não ter desistido de mim (risos). Não tenho palavras para expressar meus agradecimentos nessa caminhada, respeitou o meu tempo de aprendizagem, mostrando os caminhos a serem seguidos. Assim, tive a oportunidade de compartilhar a sua sabedoria, o que permitiu a confrontação das minhas concepções arraigadas e possibilitou novos olhares para o ensino de Ciências. Um cheiro grande para a minha baiana mais francesa ou francesa mais baiana (ainda tenho dúvidas, risos). Muito obrigada!

Às joias vivas e presentes na minha vida, meus amigos.

À Karine Nair Sousa, uma anjinha baiana, pelos laços de amizade fortalecidos, pelo companheirismo, pelo encorajamento e pelos momentos de descontração e pela sua inestimável contribuição neste estudo, com colaborações e discussões pertinentes. Agradeço à Karine e ao seu esposo Thiago, pela concessão de uso do escritório como espaço de estudo!

À Dorisdei Rodrigues, pela amizade, pelas discussões nos trabalhos compartilhados e pelas sugestões de leituras. 
Yes, we can! (risos). À Ana Tereza, à Ângela Sillos e à Grazielle Aparecida, pela amizade, pelo apoio, pelo carinho e pelos almoços divertidos. E à Maria, que gentilmente preparava nossas refeições.

À Ana Aparecida Moura e ao Marcelo Fabiano Rodrigues, pela amizade, pela atenção e pelas contribuições nesta caminhada.

Ao meu chefe, Rubens Pereira, pela concessão de um mês de licença-prêmio no período de seleção da pós-graduação.

Aos meus amigos da Gerência de Educação Básica da Coordenação Regional de Ceilândia, pelo apoio e pelo incentivo. Em especial, à equipe de Ciências - Elinton, Roblêdo, Teles e Werner - e aos tutores do Programa Ciência e Tecnologia com Criatividade, pela amizade incondicional nestes últimos sete anos e pelos convites para as confraternizações do grupo durante o período de afastamento.

À Luiza Caroline Vieira, por me ajudar a canalizar o brainstorm de ideias, pela amizade construída e pelas revisões de texto.

Aos colegas de todas as disciplinas, pelos momentos e pelos conhecimentos compartilhados, em especial, aos orientandos da Professora Maria Helena.

À turma da disciplina Espaços de Cinema: Natureza e Cultura em Imagens e Sons, por possibilitar discussões profícuas e por desenvolver um olhar crítico sobre o uso do cinema em sala de aula. Em especial, à Professora Laura Coutinho e aos amigos Adriana, Emília, Erizaldo, Patrícia, "Rosanas", Tânia e Verônica. Aquele abraço...

À Nádia M. Queiroz, in memorian, pelo primor de seu trabalho, que nos inspirou, apesar de não tê-la conhecido.

Ao meu ex-orientador José Roberto Pujol Luz, pela motivação e pelo incentivo em buscar uma pós-graduação na área de Educação.

À professora Célia Maria Soares Gomes de Sousa, pela consulta e pelo empréstimo dos exemplares da revista Enseñanza de Las Ciencias.

Aos Professores do Programa de Pós Graduação em Educação, especialmente, a Bernardo Kipnis, a Carmem Tacca, a Célia de Sousa, a Elizabeth Tunes, a Lívia Borges, a Maria Abádia da Silva, pela sabedoria e por proporcionar momentos de aprendizagem e de discussões que possibilitaram outra visão sobre a educação.

À Banca Examinadora, pela avaliação e pelas sugestões no projeto de qualificação e por ter aceitado o convite. 
À direção, aos corpos docente e discente das escolas da Secretaria de Estado de Educação do Distrito Federal em que foram realizados o ensaio metodológico e a nova metodologia.

Às professoras e, em especial, aos alunos participantes da pesquisa, que carinhosamente me chamavam de Tia Lu, pelo empenho em desenvolver as atividades propostas. Um beijo grande!

À Secretaria da Pós-Graduação em Educação, pela cordialidade e pela atenção às solicitações encaminhadas.

Aos funcionários da Biblioteca Central da Universidade de Brasília, pela disposição e pela colaboração durante a pesquisa bibliográfica.

À Juliana de Társia e à sua equipe da Gerência de Tecnologia, pelo apoio, pelo carinho e pela disponibilidade em ajudar nas dúvidas referentes aos desenhos animados do catálogo da videoteca.

À Iraci e à sua equipe do Núcleo de Afastamento para estudos da Escola de Aperfeiçoamento dos Profissionais da Educação, pela atenção e pelo empenho, principalmente no período da licença-maternidade.

À Secretaria de Estado e Educação do Distrito Federal e ao Governo do Distrito Federal, pela concessão da licença para afastamento de estudos. 


\section{RESUMO}

Sob a ótica da teoria histórico-cultural, desenvolvida pelo psicólogo russo Lev Seminiovich Vigotski, buscou-se analisar em que medida onze alunos dos Anos Iniciais ( $5^{\circ}$ ano) do Ensino Fundamental de uma escola pública do Distrito Federal apropriam-se das informações científicas apresentadas no desenho animado Meu corpo, Meu mundo, produzido pela Fundação Oswaldo Cruz - FIOCRUZ, por meio da FIOCRUZ Vídeo, para fins educativos. E, ainda, como essas informações são articuladas no processo de formação do conceito de ecossistema no Ensino de Ciências. A escolha deste desenho animado justifica-se por apresentar o conceito de ecossistema em sua narrativa. Os conceitos ou as informações apresentados na narrativa não ensinam aos alunos somente por meio da exibição do desenho animado, sendo necessária a mediação pedagógica. Para o desenvolvimento do estudo, a metodologia foi composta por duas etapas. Na primeira, foi realizado um ensaio metodológico que teve o intuito de testar os instrumentos para a realização da pesquisa. Os resultados gerados, nesse ensaio metodológico, subsidiaram o planejamento da nova proposta, o que permitiu redefinir a metodologia da tese e a mudança do conceito a ser trabalhado com os alunos. A segunda etapa, a nova proposta, se consistiu na metodologia efetiva da tese. Ao total, foram realizadas quinze atividades nesta nova proposta, distribuídas em quatro períodos - interação, pré-exibição do desenho animado (identificação dos conhecimentos prévios), sessão de desenho animado (apresentação do conceito e identificação dos atributos) e pósexibição do desenho animado (avaliação da aprendizagem do conceito). Essas atividades foram gravadas em áudio, o que facilitou a posterior análise. Foram realizadas ainda entrevistas com os alunos, antes e depois da exibição do desenho animado. Com base no aporte teórico, a análise dos dados gerados segue em três sentidos: evidências que permitam indicar variações no desenvolvimento do pensamento do aluno (tipos ou subtipos que foram identificados), o papel da mediação pedagógica na tomada de consciência e, por último, o desenvolvimento do significado da palavra durante todo o experimento. Após a análise dos resultados gerados na segunda etapa, foram identificados os três tipos de pensamento (sincrético, por complexos e conceitual) e os seus subtipos (imagem sincrética formada pela percepção imediata, pseudoconceito e conceitos potenciais). Pode-se inferir que o emprego da palavra ecossistema teve um papel fundamental na orientação do processo de formação de conceitos, corroborando os pressupostos teóricos, o que demonstrou um avanço do significado da palavra e das ideias apresentadas pelos alunos e a constatação do pleno desenvolvimento do pensamento infantil, em que podem coexistir os diferentes tipos e subtipos de pensamento no decorrer do processo de formação de conceito. O desenho animado constituiu-se em um recurso pedagógico pertinente ao processo de ensinoaprendizagem de conceitos, por possibilitar a identificação e a discussão de atributos do conceito apresentados na narrativa desde que seja mediado pelo professor e, ainda, integrar o cotidiano dos alunos com o uso de novas tecnologias no ambiente escolar.

Palavras-chave: Desenho animado, Ecossistema, Ensino de Ciências, Formação de conceito, Vigotski. 


\begin{abstract}
In the cultural-historical theory perspective developed by the Russian psychologist Lev Seminiovich Vigotski, this research aims at analyzing in which degree eleven years old students of the early basic education (5th year) in a public school in the Federal District of Brazil have assimilated the scientific information presented in the cartoon Meu corpo, Meu mundo [My Body, My World], produced by the Oswaldo Cruz Foundation -FIOCRUZ, through FIOCRUZ Video, for educational purposes; and also how this information is articulated in the process of forming the ecosystem concept in Science Education. The presentation of the ecosystem concept in its narrative justifies the choice of this cartoon. The concepts or the information presented in this cartoon does not teach the students only by its exhibition, for this reason the mediation is required. To realize this study, the methodology was divide into two steps. The first step was to realize a methodological essay in order to test the instruments for this research. The results generated by this methodological essay contributed the planning for a new proposal, which allowed to redefine the methodology of this thesis and to change the concept worked with students. The second step dealt with the new proposal and consisted of effective methodology of the thesis. In total there were fifteen activities, that were distributed into four periods - interaction; before the cartoon exhibition (identification of previous knowledge); cartoon session (presentation of concepts and identification of attributes); and after cartoon exhibition (evaluation of the learning of concept).These activities audios were recorded, which facilitated the further analysis. Interviews were also carried out with the students before and after the cartoon exhibition. Based on the theoretical framework, the analysis of data generated follows three ways: evidences that permit to indicate variations in the student's thought development (types or subtypes that have been identified), the role of pedagogical mediation in the awareness and, finally, the development of the meaning of the word during the whole experiment. After the analysis of the results generated by the second step, the three types of thinking were identified (syncretic, by complex and conceptual) as well its subtypes (syncretic image formed by the immediate perception, pseudo-concept and potential concepts). After this analysis, it was concluded that the use of the word ecosystem had an essential role in the guidance of the concepts formation process, confirming the theoretical assumptions, which demonstrated an advance of the meaning of words and the ideas presented by the students, and the verification of the full development of children's thought, in which the different types and subtypes of thinking during the concepts formation process can coexist. The cartoon is a relevant educational resource for the teaching-learning concepts process by enabling the identification and the discussion on the attributes of the concept presented in the narrative, since this is mediated by the teacher, and integrating the daily routine of students with the use of new technologies in the school environment.
\end{abstract}

Key words: Cartoon, Ecosystem, Science teaching, Concept Formation, Vigotski. 


\section{RESUMEN}

Bajo la óptica de la teoría histórico-cultural, desarrollada por el psicólogo ruso Lev Seminiovich Vigotski, se buscó analizar en qué medida once alumnos de los Años Iniciales (quinto grado) de la Enseñanza Fundamental de una escuela pública de Distrito Federal se han apropiado de las informaciones científicas presentadas en el dibujo animado Mi cuerpo, $\mathrm{Mi}$ mundo, producido por la Fundación Oswaldo Cruz - FIOCRUZ, por medio de la FIOCRUZ Videos, para fines educativos. Y, además, cómo estas informaciones son articulas en el proceso de formación del concepto de ecosistema en la Enseñanza de Ciencias. La elección de este dibujo animado se justifica por la presentación del concepto de ecosistema en su narrativa. Los conceptos o las informaciones presentadas en la narrativa no enseñan a los alumnos solamente por medio de la exhibición del dibujo animado, siendo necesaria la mediación pedagógica. Para el desarrollo del estudio, la metodología fue compuesta por dos etapas. En la primera, fue realizado un ensayo metodológico que tuvo el objetivo de poner a prueba los instrumentos para la realización de la investigación. Los resultados generados, en este ensayo metodológico, subsidiaron el planeamiento de la nueva propuesta, lo que permitió redefinir la metodología de la tesis y el cambio del concepto que será trabajado con los alumnos. La segunda etapa, la nueva propuesta, se constituye en la metodología efectiva de la tesis. Al total, fueron realizadas quince actividades distribuidas en cuatro períodos interacción, pre-exhibición del dibujo animado (identificación de los conocimientos previos), sesión de dibujo animado (presentación del concepto e identificación de los atributos) y postexhibición del dibujo animado (evaluación de la aprendizaje del concepto). Estas actividades fueron grabadas en audio, lo que facilitó su posterior análisis. También fueron realizadas entrevistas con los alumnos, antes y después, de la exhibición del dibujo animado. Con base en el aporte teórico, el análisis de los datos generados sigue en tres direcciones: evidencias que permitan indicar las variaciones en el desarrollo del pensamiento del alumno (tipos o subtipos que fueron identificados), el papel de la mediación pedagógica en la toma de conciencia y, por último, el desarrollo del significado de la palabra durante todo el experimento. Después del análisis de los resultados generados en la segunda etapa, fueron identificados los tres tipos de pensamiento (sincréticos, por complejos y conceptual) y sus subtipos (imagen sincrética formada por la percepción inmediata, pseudoconcepto y conceptos potenciales). Se puede inferir que el uso de la palabra ecosistema tuvo un papel fundamental en la orientación del proceso de formación de conceptos, corroborando los presupuestos teóricos, lo que demostró un avanzo de lo significado de la palabra y de las ideas presentadas por los alumnos y la constatación del pleno desarrollo del pensamiento infantil, en lo que puede coexistir los diferentes tipos y subtipos de pensamiento durante el proceso de formación de concepto. El dibujo animado se constituyó en un recurso pedagógico pertinente al proceso de enseñanza-aprendizaje de conceptos, por posibilitar la identificación y la discusión de atributos del concepto presentado en la narrativa desde que sea mediado por el profesor y, también, integrar el cotidiano de los alumnos con el uso de nuevas tecnologías en el ambiente escolar.

Palabras claves: Dibujo animado, Ecosistema, Enseñanza de Ciencias, Formación de concepto, Vigotski. 


\section{LISTA DE FIGURAS}

Figura 1. Pinturas rupestres da Caverna de Altamira, Espanha, e pinturas rupestres no Brasil, respectivamente.

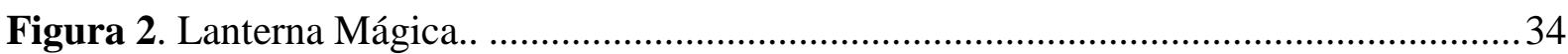

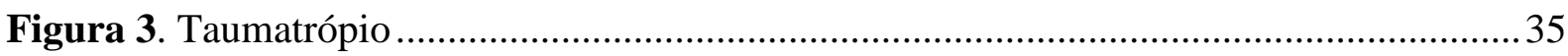

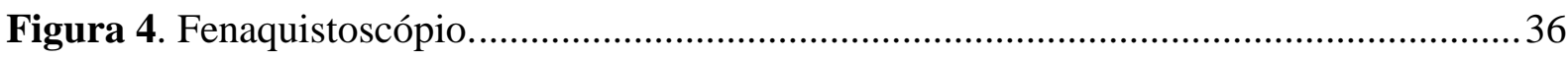

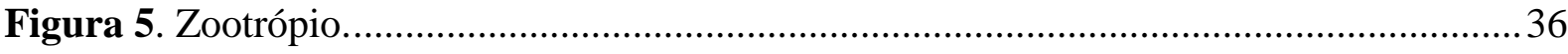

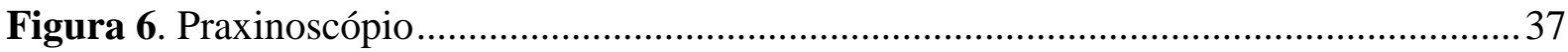

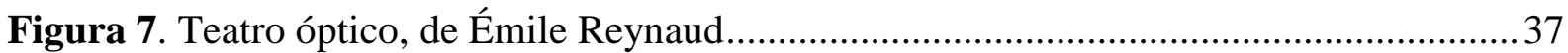

Figura 8. Imagem de um trecho do desenho animado Fantasmagorie .................................. 38

Figura 9. Exemplos de diferentes técnicas como a rotoscopia (Betty Boop, 1930), o stop motion (Pingu, 1986) e a animação digital (Sítio do Pica Pau Amarelo, 2010)....................... 39

Figura 10. Gato Félix, Betty Boop e Pica-pau, respectivamente.

Figura 11.Cena do longa-metragem História antes de uma História, produzido pelo NCAC .43

Figura 12. Animações criadas por computação gráfica como Toy Story, Cassiopéia e Brasil Animado, respectivamente

Figura 13. Baratinha Rodox, Baianinho e Menina da Claybom, respectivamente.

Figura 14. Epidiascópio

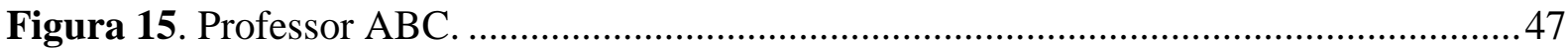

Figura 16. Cenas decupadas do curta-metragem de animação Um Rei Fabuloso....................49

Figura 17. Diferentes personagens Zé Gotinha, desde a sua criação em 1986 até a última campanha em 2013

Figura 18.As personagens Kika e Chico, respectivamente ..................................................51

Figura 19. Igarapé Mágico e Pequenos Cientistas (Diná e Rex) ..........................................56

Figura 20. Personagens de desenhos animados Dexter e Jimmy Neutron, respectivamente .. 63

Figura 21. As princesas da Disney. Texto adaptado da ilustração original. 70

Figura 22. Principais personagens da série Invasão Plâncton. Da esquerda para a direita, Pulpo Calamares, Capitão John C. Star e Ana Medusa, respectivamente 111

Figura 23. Mapa conceitual sobre ecossistema.. 116

Figura 25. Professor Lecré e Família Tal, respectivamente.

Figura 24. Ficha técnica e capa do DVD Anima Saúde, respectivamente. 118

Figura 26. Computador Interativo e Lousa Digital. 
Figura 27. Imagem utilizada na folha disponibilizada aos alunos para a produção de texto na Atividade 4..

Figura 28. Chris, Aviva e Martin são as personagens do desenho animado Aventuras com os

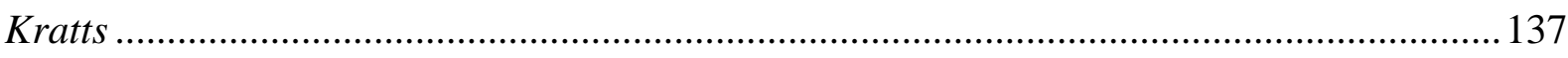

Figura 29. Esquema do aspecto geográfico do Cerrado utilizado na Atividade 8 ...............138

Figura 30. Exemplos de máscaras confeccionadas pelos alunos. Caracol, leão, macaco e sapo, respectivamente. 


\section{LISTA DE GRÁFICOS}

Gráfico 1. Nomes dos seres vivos e número de vezes em que foram citados pelos alunos. .146

Gráfico 2. Agrupamento por classe dos seres vivos citados pelos alunos............................. 146

Gráfico 3. Nomes dos seres não vivos citados pelos alunos............................................. 147

Gráfico 4. Agrupamento de elementos considerados seres não vivos pelos alunos.............. 147 


\section{LISTA DE QUADROS}

Quadro 1. Quadro síntese dos artigos, dissertações e teses identificados a partir das palavraschaves desenho animado e educação utilizadas na revisão bibliográfica

Quadro 2. Principais conceitos abordados na narrativa do desenho animado Меи corpo, meu mundo.

Quadro 3. Cenas decupadas por minuto com as imagens correspondentes. 128

Quadro 4. Momentos de pausa, assertivas e questionamentos referentes à Atividade 5......130 Quadro 5. Momentos de pausa, imagens, assertivas e questionamentos referentes à Atividade 6. 132

Quadro 6. Cenas decupadas, imagens e palavras-chave referentes à Atividade 7 . 133

Quadro 7. Imagens fixas de seres vivos do ecossistema Cerrado utilizadas na Atividade 8.139

Quadro 8. Resumo e o tempo aproximado de cada atividade desenvolvida com os alunos .142

Quadro 9. Lista de seres vivos e não vivos compilados na lousa branca da sala de aula. .... 148

Quadro 10. Compilação dos dados gerados na Atividade 1 153

Quadro 11. Subdivisão realizada pelos alunos, referente ao grupo inicial de seres vivos....161

Quadro 12. Cadeia alimentar elaborada pelos alunos na Atividade 3.2. 169

Quadro 13. Compilação dos dados gerados da Atividade 4.1 173

Quadro 14. Sequência da narrativa remontada pelos alunos na lousa branca, referente à Atividade 4. 176

Quadro 15. Compilação dos dados gerados a partir das manifestações dos Grupos A e B na Atividade 5 . 178

Quadro 16. Compilação dos dados gerados pelos grupos A e B na Atividade 6. 180

Quadro 18. Cadeias ou teias alimentares elaboradas pelos alunos, referentes à Atividade 8.

Quadro 19. Quadro comparativo das atividades em que o conceito ecossistema foi abordado. 


\section{LISTA DE SIGLAS E ABREVIATURAS}

ABRAPEC - Associação Brasileira de Pesquisa em Educação em Ciências ANIMA MUNDI - Festival Internacional de Animação

ANIMALDIÇOADOS - Festival Internacional de Animação de Horror ASIFA - Association Internacionale du Film d'Animation (França)

BCE - Biblioteca Central da Universidade de Brasília

BDTD - Biblioteca Digital de Teses e Dissertações

CAPES - Coordenação de Aperfeiçoamento de Pessoal de Nível Superior

CCBB - Centro Cultural Banco do Brasil

$\mathrm{CM}$ - Currículo em Movimento

CMAP Tools - Concept Map Tools

CTC - Programa Ciência e Tecnologia com Criatividade

EJA - Educação de Jovens e Adultos

EMBRAPA - Empresa Brasileira de Pesquisa Agropecuária

ENSAIO - Revista de Educação em Ciências

ERIC - Education Resources Information Center

EUA - Estados Unidos da América

FICI - Festival Internacional de Cinema Infantil

FIOCRUZ - Fundação Oswaldo Cruz

FPS - Funções Psíquicas Superiores

FUMDHAM - Fundação Museu do Homem Americano

GDF - Governo do Distrito Federal

GTEC - Gerência de Tecnologia

IBICT - Instituto Brasileiro de Informação em Ciência e Tecnologia

$\mathrm{IMDb}$ - The Internet Movie Database

INC - Instituto Nacional de Cinema

INCE - Instituto Nacional de Cinema Educativo

MASP - Museu de Arte de São Paulo

MUAN - Manipulador Universal de Animações

NCAC - Núcleo de Cinema de Animação de Campinas

OCDE - Organização para a Cooperação e Desenvolvimento Econômico

PCN - Parâmetros Curriculares Nacionais

PPGE - Programa de Pós-Graduação em Educação 
PISA - Programa Internacional de Sistema de Avaliação

SACI - Sistema Avançado de Comunicações Interdisciplinares

SAEB - Sistema de Avaliação da Educação Básica

SEED - Secretaria de Educação a Distância

SEE-DF - Secretaria de Estado de Educação do Distrito Federal

SESC - Serviço Social do Comércio

SLU - Serviço de Limpeza Urbana do Distrito Federal

TCLE - Termo de Consentimento Livre e Esclarecido

UFRRJ - Universidade Federal Rural do Rio de Janeiro

UnB - Universidade de Brasília 


\section{SUMÁRIO}

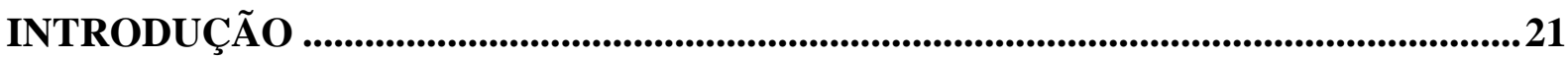

CAPÍTULO 1 - O DESENHO ANIMADO EM CONTEXTOS EDUCATIVOS ..............31

1.1 Da ilusão do movimento à computação gráfica................................................................ 32

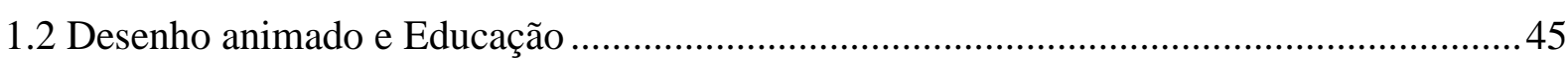

1.3 Contextos de produção ou de indicação de desenhos animados para o uso nas escolas ....52

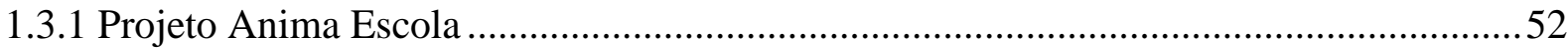

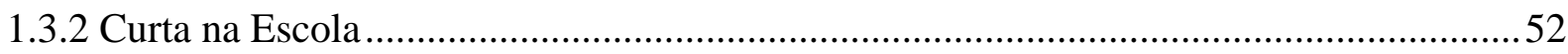

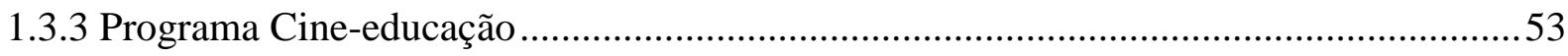

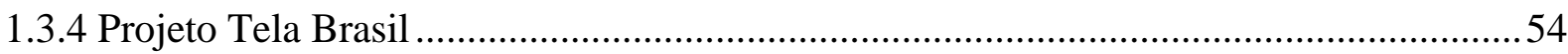

CAPÍTULO 2 - PESQUISAS SOBRE DESENHO ANIMADO, ENSINO DE CIÊNCIAS

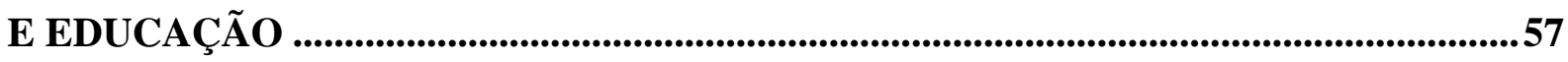

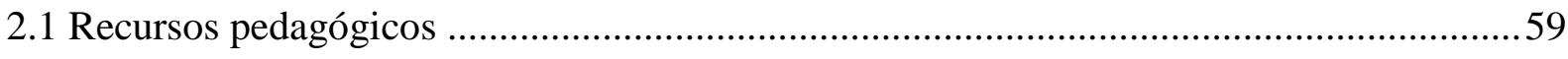

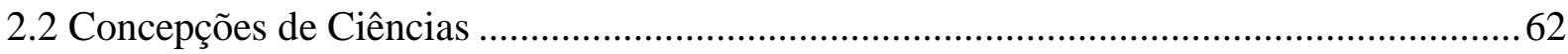

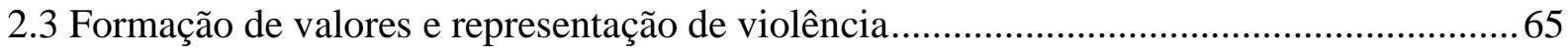

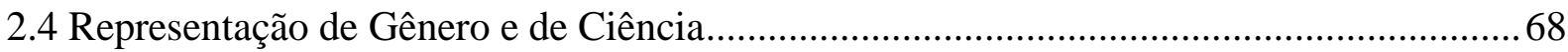

CAPÍTULO 3 - O PROCESSO DE FORMAÇÃO DE CONCEITO.....................................75

3.1 Os tipos de pensamento identificados nos estudos sobre formação de conceitos .............. 84

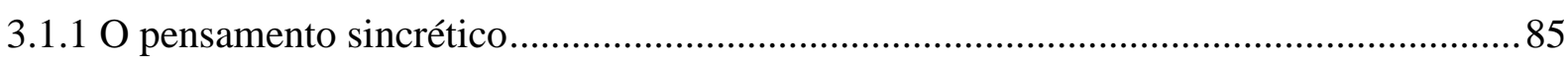

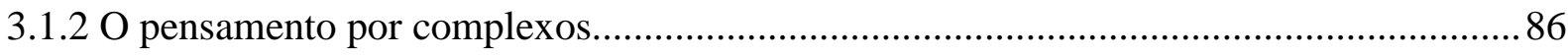

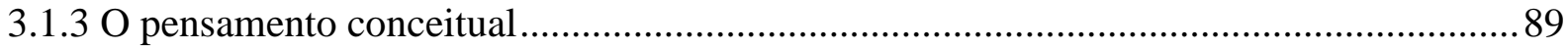

3.2 Aprendizagem conceitual, mediação pedagógica e papel do professor ..............................94

3.2.1 A mediação pedagógica e o papel do professor ........................................................... 102

CAPÍTULO 4 - AS TRAJETÓRIAS ANIMADAS................................................................. 108

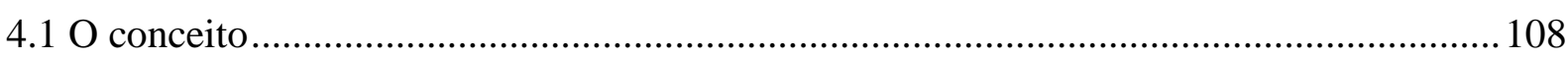

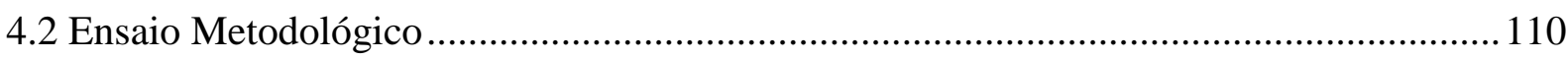

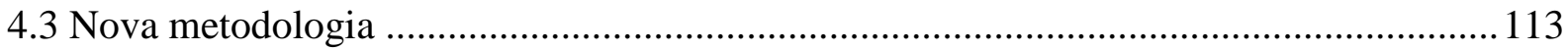

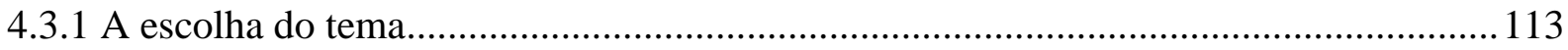

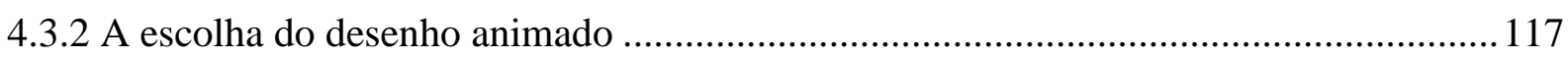

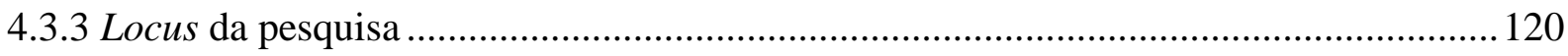

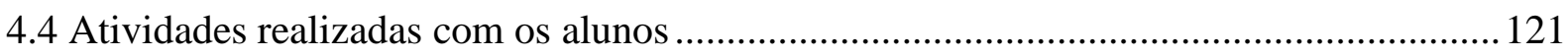

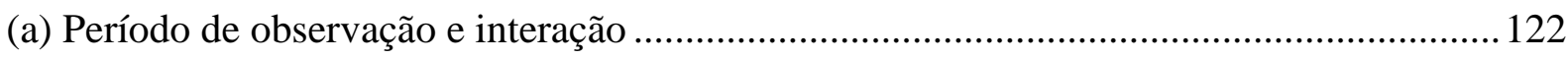

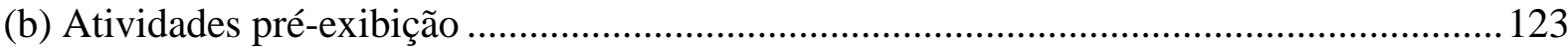




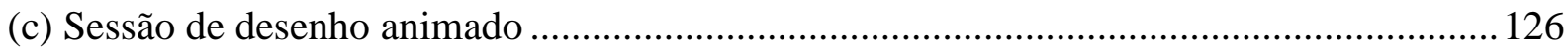

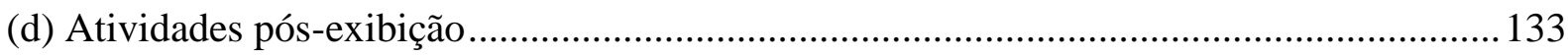

CAPÍTULO 5 - ANÁLISE E DISCUSSÃO DOS DADOS GERADOS .............................141

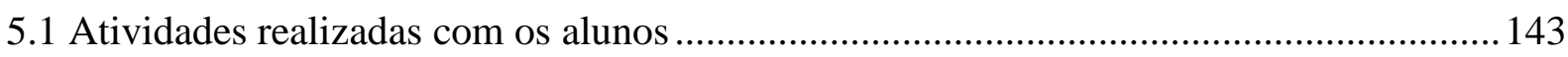

(a) Períodos de observação e interação................................................................................ 143

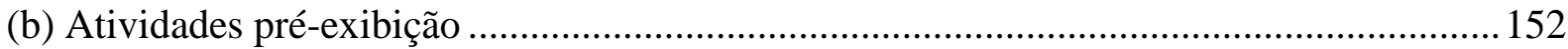

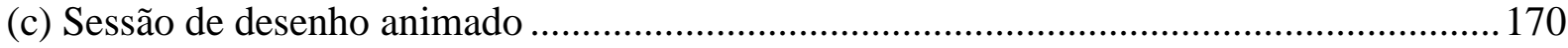

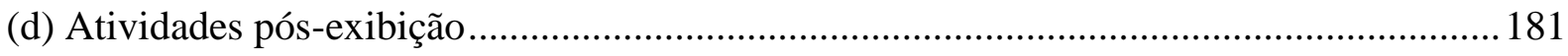

CAPÍTULO 6 - AS TRAJETÓRIAS CONTINUAM ANIMADAS....................................206

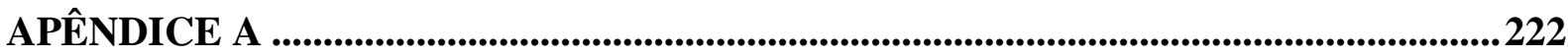

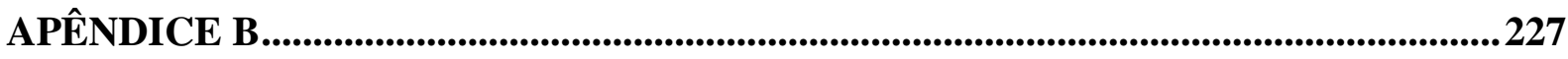

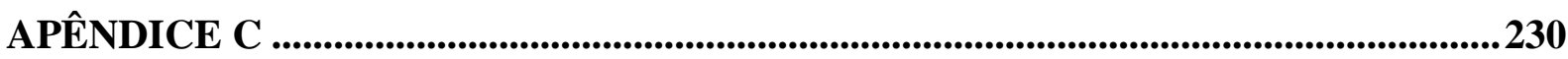

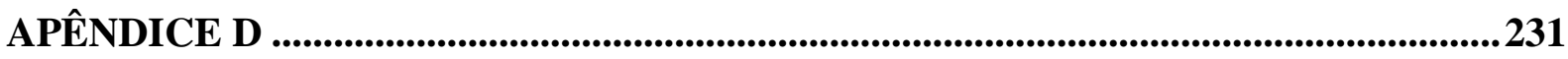

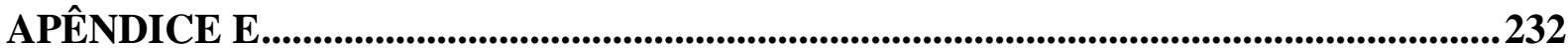

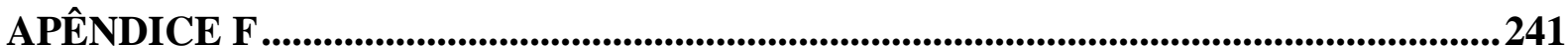

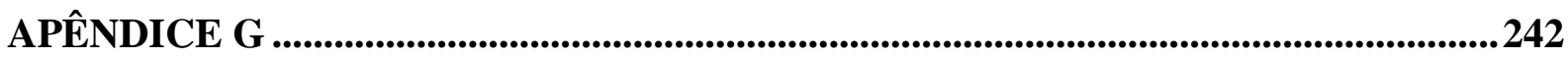

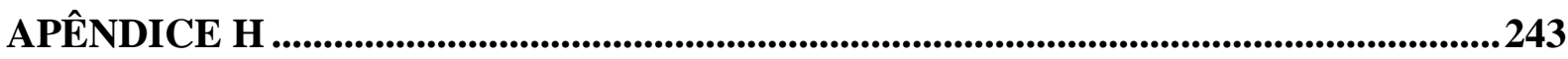

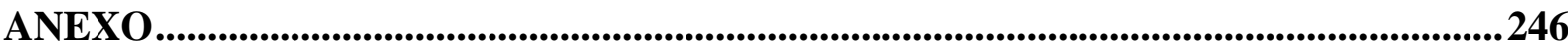




\section{INTRODUÇÃO}

Após a conclusão do Ensino Médio, eu estava em dúvida entre os cursos de Biologia, Comunicação Social e Engenharia Elétrica. A opção pela primeira área foi motivada pelas excelentes professoras que tive durante o período escolar. No sexto semestre do curso de licenciatura em Ciências, com habilitação em Biologia, assumi como professora efetiva de Ciências Naturais na Secretaria de Educação do Distrito Federal- SEE-DF, com apenas 20 anos de idade. Na primeira escola em que lecionei, os funcionários me confundiam com os alunos, cheguei a ser barrada na porta da escola (risos) e a mãe de um aluno contestou a minha idade e o meu diploma.

Nesta mesma escola, me deparava com sete turmas de $6^{\circ}$ e $7^{\circ}$ anos. Os alunos me olhavam, alguns desconfiados, esperando mais uma aula. Nesse momento, já havia elaborado o planejamento da aula a ser ministrada. Queria aulas diferentes das que eu tive no ensino fundamental, que se limitaram ao quadro e ao livro didático! Aulas em que os alunos tivessem o prazer de aprender, que fossem divertidas e instigantes, nas quais o conhecimento científico não fosse visto como algo inalcançável, podendo também estar presente nas coisas mais simples.

Os desafios estavam lançados! Para superar alguns obstáculos como a cultura do ensino livresco como principal recurso pedagógico e o excesso de conteúdo do currículo prescrito e o desinteresse dos alunos. Diante desses obstáculos, eu me questionava: que formação se pretende oferecer ao aluno? Como a escola, na figura do professor, pode contribuir como promotora do desenvolvimento intelectual?

A reflexão sobre a prática docente começou a fazer parte do planejamento semanal das aulas, em busca de atividades que contemplassem outro tipo de aluno, o aluno participativo, ao contrário do aluno passivo que assimila ou reproduz conteúdos escolares. A inclusão de materiais disponíveis na escola combinadas com a apresentação oral dos trabalhos, os experimentos, as visitas direcionadas e o desenvolvimento de projetos proporcionaram atividades diversificadas para despertar o interesse do aluno. $\mathrm{O}$ objetivo dessas atividades era fazer com que esse aluno percebesse que os conteúdos iam além do livro-texto e da sala de aula, possibilitando uma mudança na relação do indivíduo com o conhecimento.

Após cinco anos de exercício efetivo na Secretaria de Educação, optei por voltar a trabalhar com pesquisa na área de Biologia, atividade iniciada no estágio realizado no Laboratório de Controle Biológico da Empresa Brasileira de Pesquisa Agropecuária EMBRAPA Hortaliças. Os estudos foram retomados com a participação como aluna 
especial em disciplinas ofertadas no curso de pós-graduação stricto sensu em Biologia Animal da Universidade de Brasília - UnB.

O contato com o professor doutor José Roberto Pujol Luz, apelidado de Pujol, recém-chegado da Universidade Rural do Rio de Janeiro - UFRRJ, despertou o interesse em realizar o mestrado no laboratório de Entomologia Forense do Departamento de Zoologia da UnB. Após a aprovação na seleção, foi necessário reduzir a minha carga de 40 horas para 20 horas. Paralelamente às atividades do Mestrado, eu elaborava minicursos intitulados de Entomologia para crianças, ministrados para professores ou estudantes de licenciatura, com a finalidade de desenvolver temas e aulas sobre os insetos.

O professor Pujol me apoiava, às vezes contrariado (risos), porque sabia o quanto eu gostava de ser professora e a minha vontade de compartilhar o meu conhecimento com outros profissionais. Ao término do mestrado, o professor Pujol me incentivou a buscar uma pós-graduação em Educação, por observar o meu apreço pela área. A ideia permaneceu adormecida durante quatro anos. Nesse período, trabalhei com formação continuada de professores, o que motivou a busca por uma pós-graduação na área. Algumas inquietações surgiram no decorrer dessa experiência. A primeira inquietação refere-se ao papel da escola como espaço de constante troca de saberes, discussão de ideias, desenvolvimento e formação do sujeito. Outra inquietação se refere aos conhecimentos ministrados. O excesso de conteúdos que priorizam a quantidade versus a qualidade e o verbalismo.

A motivação em realizar um doutorado na área de Educação ressurgiu em 2010, quando atuava como coordenadora intermediária ${ }^{1}$ do projeto Ciência e Tecnologia com Criatividade - CTC. Nesse ano, optei por realizar a inscrição no Programa de PósGraduação em Educação - PPGE da Universidade de Brasília, na linha de pesquisa de Processos de Ensino e Aprendizagem dos Conhecimentos Científicos e Tecnológicos. Para atender as exigências do programa, apresentei um projeto sobre o ensino de entomologia, pois pretendia estabelecer relação com a temática trabalhada no mestrado e nos trabalhos que desenvolvia nos cursos de formação continuada de professores.

No contexto escolar, a demanda de novas informações pode se apresentar sob a forma de novos conteúdos que, consequentemente, exigem dos professores, como

${ }^{1} \mathrm{O}$ coordenador intermediário é lotado na Coordenação Regional de Ensino existente em cada cidade satélite do Distrito Federal e atua como mediador entre as Coordenações Centrais da Secretaria de Educação do Distrito Federal e as escolas pertencentes à Coordenação Regional. A função desempenhada pelo coordenador intermediário é apoiar, acompanhar e avaliar o desenvolvimento de ações e projetos nas escolas e atender as demandas de cada etapa ou modalidade composta por equipes específicas e, ainda, caso seja necessário, ministrar cursos, oficinas e palestras para os professores. 
principais atores na mediação do conhecimento produzido pela humanidade, novas formas de ensinar. Entre essas formas, destacam-se os desenhos animados, que podem ser utilizados como recurso pedagógico.

Conforme as autoras Pacheco (1998) e Mareuse (2007), há pesquisas que revelam que as crianças passam uma boa parte do dia em frente à televisão, ou seja, os meios de comunicação audiovisuais, que incluem os desenhos animados, fazem parte da relação social moderna de muitos alunos.

Ainda segundo Pacheco (1998), esses veículos de comunicação não apenas transmitem informações, como também influenciam o estilo de vida da sociedade, os modos de organizar a vida cotidiana, as formas de falar e, muitas vezes, até de pensar, bem como influenciam o consumismo exacerbado, o que é facilmente percebido pela quantidade de acessórios, alimentos, brinquedos, roupas, materiais de higiene (xampu, pasta de dente etc.) anunciados na televisão ao público infantil.

Os desenhos animados fazem parte da programação televisiva, tanto de canais abertos quanto de canais fechados, alguns específicos para o público infantil. Entre a variedade de desenhos animados, existe uma grande quantidade que retrata a ciência, a pesquisa científica e o trabalho do cientista. Por exemplo: Aventuras com os Kratts, Dr. Raio X, Jimmy Neutron, As Meninas Superpoderosas, O mundo divertido de Peep, Timothy vai à escola, T.R.E.X.C.I e O laboratório de Dexter, entre outros. Vale ressaltar que os exemplos citados de desenhos animados veiculados em canais televisivos serão denominados de desenhos animados comerciais.

Além dos temas científicos constantemente presentes nos desenhos animados, Siqueira (2006) relata que os cientistas são figuras muito exploradas na animação infantil, que mesclam as representações ${ }^{2}$ de ciência e de cientista com a fantasia e os conteúdos apresentados nas narrativas dos desenhos animados, muitas vezes extrapolando a realidade. Já Massarani (2005) ressalta que a imagem de cientista veiculada pela televisão, assim como pelos livros didáticos e pelas histórias em quadrinhos, é desarticulada com a realidade:

No Brasil, os livros didáticos são uma das principais fontes de informação relacionadas com a ciência. Mas, muitas vezes, tais livros veiculam erros conceituais graves e apresentam a ciência como algo desvinculado da vida cotidiana. Em outros veículos, como na TV e nas histórias em quadrinhos - fontes de informações importantes de ciência - geralmente, a imagem transmitida é a do cientista louco,

\footnotetext{
${ }^{2}$ Neste caso, considera-se representação no sentido de imagem escolhida para representar a ciência e o cientista.
} 
descuidado, de jaleco, de sexo masculino e cujo trabalho é inventar "coisas" totalmente desarticuladas da realidade. Outras vezes, o cientista é um homem perverso, cujas descobertas e inventos são maléficos para a humanidade e para o planeta (MASSARANI, 2005, p. 7, grifo nosso).

Ainda nesse sentido, as concepções de ciência, de atividade científica e de experimentos científicos também são retratadas de formas equivocadas nos desenhos animados. Alguns estudos que analisaram desenhos e filmes de animação, como o de Mesquita e Soares (2008) e de Tomazi et al (2009), corroboram as questões levantadas sobre as concepções de ciência e a imagem de cientista como louco, solitário e dotado de inteligência acima do normal.

Para Trivelato e Silva (2011), é preciso entender a ciência também como uma produção cultural:

Entendendo a Ciência como uma produção cultural e partindo da concepção de que a aprendizagem de seus conteúdos em sala de aula é reelaborada individualmente, como uma síntese pessoal que engloba a vivencia de cada aluno, é importante que não se desconsidere a interferência da mídia nesse processo (TRIVELATO; SILVA, 2011, p. 42).

As autoras ainda destacam que é oportuno o professor permitir-se trabalhar os aspectos positivos do uso dessas ferramentas midiáticas sobre os negativos e aproveitálas como recurso pedagógico, de modo a tornar a aprendizagem ainda mais prazerosa (TRIVELATO; SILVA, 2011).

Nesse sentido, a escola constitui-se em um espaço onde as diferentes formas de cultura têm aportes da cultura científica, das novas tecnologias, dos diversos meios de comunicação e, principalmente, dos sujeitos envolvidos (professores, alunos e pais etc.). Além disso a escola reflete uma organização própria, que é a cultura escolar, apresentada e construída coletivamente. Segundo Trivelato e Silva (2011, p. 44), “a escola e professores são sujeitos no processo de articulação dos conteúdos da mídia com as culturas escolares", sempre com o objetivo de fomentar a aprendizagem dos conceitos, atribuindo-lhe novos sentidos e motivações.

Para Sforni (2004), a escola desempenha um papel relevante na apropriação da cultura, na compreensão dos produtos elaborados por uma sociedade e no uso dos diferentes produtos que possibilitam a aquisição de instrumentos cognitivos.

A apropriação da cultura é propiciada pela educação, tendo a educação escolar um papel significativo. Dessa forma, o acesso ao ensino não é 
apenas direito do cidadão, ou apenas necessário à formação para o trabalho; nem se destina a desenvolver resistência ou adequação do indivíduo à sociedade; mas é condição para aquisição de instrumentos cognitivos que permitam o trânsito consciente no interior da sociedade em que está inserido, é o meio de se adquirir competência no uso de signos, códigos e instrumentos desenvolvidos socialmente. Por ser humano, somente por ser humano, cada indivíduo, estando em uma sociedade letrada, deve ter acesso a essa cultura (SFORNI, 2004, p. 23-24).

Para essa autora, os instrumentos cognitivos constituem-se em meios para os alunos compartilharem os elementos produzidos coletiva e historicamente pela sociedade e para possibilitar o acesso a essa cultura. Como exemplo, pode-se citar os recursos audiovisuais utilizados na escola como instrumentos cognitivos, que permitem o acesso às diferentes formas de expressão da cultura. O desenho animado, o documentário ou o filme são exemplos de recursos audiovisuais que podem apresentar diversas perspectivas de uma cultura.

Além disso, o próprio currículo da SEE-DF - Currículo em Movimento ${ }^{3}-$ incentiva práticas educativas que permitam reflexões para além da sala de aula.

A organização curricular deve proporcionar discussão e reflexão da prática pedagógica para além da sala de aula, ampliando-a a toda unidade escolar e sua comunidade, como exercício de planejamento coletivo e de ação concretizadora da proposta pedagógica; uma educação para além da escola, que busque ensinar na perspectiva de instigar, provocar, seduzir o outro para o desejo de aprender, por meio de relações que possam ser estabelecidas entre conteúdos e a realidade dos estudantes (DISTRITO FEDERAL, 2014a, p. 11).

Nessa perspectiva, a educação busca ir além dos conteúdos curriculares, a partir de práticas pedagógicas que possam extrapolar o currículo prescrito ${ }^{4}$ e que possam integrar conhecimentos de diferentes áreas com a realidade dos alunos.

Sendo assim, uma das tarefas do ensino de Ciências "é a mediação entre educação, cultura cientifica e indústria cultural"5 (TRIVELATO; SILVA, 2011, p. 42). Mediação essa que, para as autoras, envolve diferentes linguagens, discussões e

${ }^{3}$ O Currículo em Movimento - CM da Educação Básica da SEE-DF é fruto das discussões com gestores e professores das Coordenações Regionais realizadas em 2011. O CM pauta-se em uma educação integral, que objetiva ampliar tempos, espaços e oportunidades educacionais e foi instituído em 2012, conforme a Lei $\mathrm{n}^{\circ}$ 4.751, de 7 de fevereiro de 2012, sobre a gestão democrática do ensino público do Distrito Federal.Em 2013, o CM entrou em vigor em caráter experimental e efetivou-se como currículo da rede em 2014.

${ }^{4}$ De acordo com Sacristán (2000, p. 104), "o currículo prescrito ocorre em todo sistema educativo, como consequência das regulações inexoráveis às quais está submetido, levando em conta sua significação social, existe algum tipo de prescrição ou orientação do que deve ser seu conteúdo, principalmente em relação à escolaridade obrigatória".

${ }^{5}$ No sentido utilizado por Theodor Adorno e Max Horkheimer. 
atribuições de significados relacionados à cultura científica sobre aspectos biológicos, históricos, culturais e à interação entre ciência, tecnologia e sociedade. A esse exemplo, há interações entre o conhecimento interdisciplinar e as concepções de aprendizagem e de ciência apresentadas nos meios de comunicação, em suas diferentes formas e linguagens, e o desenho animado conforma-se em uma destas representações.

Para tanto, o desenho animado como um recurso audiovisual precisa ser encarado não apenas como entretenimento ou complemento, mas como parte de um processo educativo de mediação entre o conteúdo científico e as diferentes formas pelas quais ele é representado socialmente (TRIVELATO; SILVA, 2011).

De acordo com Aparici Marino e García Matilla (1998), a utilização de meios audiovisuais permite avaliar os conhecimentos, as atitudes e, também, a própria metodologia de trabalho que é posta em prática, além de permitir o envolvimento do aluno com o ensino, uma forma oportuna de se aprender os conteúdos curriculares ${ }^{6}$.

Em consonância com as ideias apresentadas anteriormente, o Currículo em Movimento dos Anos Iniciais do Ensino Fundamental da SEE-DF leva em consideração o uso de meios audiovisuais como uma estratégia didática para a "Interpretação de personagens de narrativas e textos infantis de espetáculos teatrais, história em quadrinhos, filmes, propagandas, desenhos animados e programas infantis de TV" (DISTRITO FEDERAL, 2014b, p. 47-55). Neste currículo, o conteúdo do componente curricular de Ciências Naturais, no que diz respeito ao uso desses recursos, refere-se à capacidade de "ler e interpretar textos informativos e imagens" (DISTRITO FEDERAL, 2014b, p.131).

Porém, os desenhos animados são pertinentes ao contexto das crianças da Educação Infantil e dos Anos Iniciais do Ensino Fundamental, seja em casa, por meio da televisão, seja por seu uso nas escolas. Os desenhos animados permeiam a vida cotidiana dos alunos por meio de diferentes tecnologias como a televisão, o celular ou o computador.

Kindel (2003) afirma que os desenhos animados podem ser utilizados tanto como atividade de entretenimento quanto como recurso didático. A autora expressa que "os desenhos animados têm assumido um papel cada vez mais significativo na vida das crianças, tendo em vista que está presente em suas casas, nas creches, nas escolas" (p. 48). A atividade de entretenimento à qual a autora se refere é o momento do vídeo,

${ }^{6}$ Entende-se por currículo: "uma construção social que preenche a escolaridade de conteúdos e orientações que nos levam a analisar os contextos concretos que lhe vão dando forma e conteúdo, antes de passar a ter alguma realidade como experiência de aprendizagem para os alunos", conforme a definição proposta por Sacristán (2000). 
prática comum em creches e pré-escolas, em que são exibidos desenhos animados, em sua maioria, em salas específicas ou na própria sala de aula.

Além do uso como entretenimento, há uma quantidade considerável de desenhos animados disponíveis na internet, assim como tutoriais e programas específicos (softwares livres) que ensinam como elaborar um desenho animado.

O Núcleo de Cinema de Animação de Campinas - NCAC oferece cursos e oficinas de animação para crianças e adultos para expressar sua imaginação e criatividade. Em 1985, o Núcleo produziu o primeiro filme com fins didáticos. Atualmente, houve uma expansão da produção de animações brasileiras em função de projetos como o AnimaTV, coordenado pelo Ministério da Cultura, e as animações importadas ou produzidas pelo Programa TV Escola do Ministério da Educação.

Os desenhos animados, assim como os filmes, possuem um potencial educativo de acordo com o conteúdo apresentado quanto às diferentes significações que emergem das relações entre o espectador e os filmes:

Parece ser desse modo que determinadas experiências culturais, associadas a uma certa maneira de ver filmes, acabam interagindo na produção de saberes, identidades, crenças, e visões de mundo de um grande contingente de atores sociais. Esse é o maior interesse que o cinema tem para o campo educacional - sua natureza eminentemente pedagógica (DUARTE, 2002, p. 18).

É a partir do conteúdo apresentado nas narrativas do desenho animado que o professor pode utilizá-lo como recurso pedagógico. As possibilidades de uso vão desde a crítica às mensagens transmitidas até o uso como ferramenta de ensino-aprendizagem. Entre as práticas educativas, destaca-se o ensino-aprendizagem de conceitos. Os desenhos animados podem ser usados na escola para apresentar conceitos novos ou já estudados que são abordados nas narrativas, no sentido de motivar o aluno, despertar o interesse e a curiosidade sobre diferentes temas. Porém, estes conceitos podem passar por um processo de reorganização e são incorporados em sentidos e significados mais simplificados para a compreensão tanto de crianças quanto de adultos.

Foi considerando os aspectos acima que o estudo, que ora apresenta-se, configurou-se a partir da elaboração de material para a oficina pedagógica intitulada de Trabalhando Ciências na Educação Infantil, para professores de Educação Infantil da Coordenação Regional de Ensino de Ceilândia, realizada em 2010 e ministrada pela entrevistadora quando atuava como coordenadora intermediária. 
$\mathrm{Na}$ elaboração do material, realizou-se um breve levantamento de desenhos animados, produzidos para o público de faixa etária de três a sete anos, e percebeu-se entre eles uma quantidade considerável que abordava temas relacionados à ciência. A partir desse levantamento sobre os desenhos animados, surgiram vários questionamentos quanto ao seu uso pedagógico: Qual o papel pedagógico dos desenhos animados? O desenho animado como recurso de ensino possibilita a melhoria do processo de ensino e aprendizagem de conceitos científicos? Como deve ser usado em situações pedagógicas? Como o conhecimento científico e o trabalho do cientista é apresentado nos desenhos animados? Que tipo de valores é apresentado nos desenhos animados? Muitas dessas questões foram estudadas por outros autores, conforme será demonstrado no capítulo que trata da revisão bibliográfica. Mas o papel pedagógico dos desenhos animados no ensino de Ciências ainda é pouco explorado.

Nessa experiência como coordenadora intermediária de um projeto de Ciências, ficou evidenciada a necessidade de uso de recursos didáticos e que pudessem auxiliar o processo de ensino e aprendizagem do conhecimento científico. Além disso, verificouse também que, embora o professor reconheça a importância da mídia como "complemento" da prática educativa e da sua onipresença na vida das crianças, poucos são aqueles que fazem uso desses recursos em sala de aula.

Não resta dúvida que o universo infantil é invadido por imagens e, muito cedo, as crianças são desafiadas a fazer a leitura dessas imagens, o que evidencia a importância da mediação do adulto no processo de decodificação das mensagens que são veiculadas por esses recursos.

Assim, pretendo demonstrar que esse tipo de mídia, para além de encantar, seduzir e divertir os seus espectadores, pode contribuir no processo de ensino e aprendizagem de conhecimentos científicos, desde que seja mediado pelo professor.

Nessa perspectiva empreende-se este estudo, cujo objetivo é analisar em que medida os alunos do $5^{\circ}$ ano do ensino fundamental se apropriam das informações científicas apresentadas em um desenho animado, produzido para fins educativos, e como essas informações são articuladas na formação do conceito de ecossistema.

Desse objetivo geral emergem os seguintes objetivos específicos: (i) identificar os conhecimentos prévios que os alunos possuem sobre o conceito de ecossistema; (ii) propor e desenvolver situações de ensino em que o desenho animado seja uma das ferramentas pedagógicas; (iii) identificar os tipos de pensamento no processo de formação de conceito; (iv) investigar o processo de formação de conceito em alunos do 
$5^{\circ}$ ano do Ensino Fundamental da Educação Básica; (v) compreender o emprego da palavra ecossistema e a aprendizagem nas atividades.

A relevância do estudo deve-se a diversos fatores: a intensa problematização sobre a formação de conceito em ensaios e artigos que tratam sobre o assunto, a escassez de pesquisas empíricas sobre o tema em contextos de sala de aula, a utilização de desenhos animados no ensino-aprendizagem de conceitos, a elaboração de metodologia específica para o desenvolvimento do estudo e a avaliação do desenho animado como recurso pedagógico.

Para desenvolver o estudo em questão, optou-se pelo referencial da teoria de desenvolvimento histórico-cultural proposto por Lev Seminiovich Vigotski ${ }^{7}$, em um contexto no qual a formação de conceito constitui-se em um dos aspectos do desenvolvimento infantil, por ponderar que o emprego funcional da palavra ou dos signos-estímulos é o meio pelo qual ocorre o processo de formação de conceito, que possibilita observar o desenvolvimento do pensamento desde a fase sincrética (pensamento concreto) até a fase abstrata (pensamento conceitual).

A tese está organizada em cinco capítulos. O primeiro capítulo apresenta as diferentes técnicas e os recursos utilizados na criação do desenho animado, desde a lanterna mágica até a computação gráfica. E, por último, apresenta um breve histórico sobre o uso do desenho animado na educação, assim como os contextos de produção e o uso de desenhos animados na e para a escola.

O segundo capítulo apresenta uma revisão bibliográfica das pesquisas realizadas na área de Ensino de Ciências e Educação, que utilizaram o desenho animado como objeto de estudo. A busca foi realizada em revistas nacionais e internacionais (nos idiomas inglês e espanhol) e nas bases nacionais de banco de teses e dissertações da Coordenação de Aperfeiçoamento de Pessoal de Nível Superior - CAPES e da Biblioteca Digital Brasileira de Teses e Dissertações - BDTD do Instituto Brasileiro de Informação em Ciência e Tecnologia- IBICT,vinculados ao Ministério da Ciência e Tecnologia e Inovação.

O terceiro capítulo aborda a formação de conceito sob a perspectiva teórica de desenvolvimento histórico-cultural de Lev S. Vigotski, na qual descreve os tipos de pensamento, a aprendizagem conceitual, a mediação pedagógica e o papel do professor no processo de formação de conceito.

\footnotetext{
${ }^{7}$ No presente trabalho, o nome Vigotski será grafado com dois “i”, conforme a transliteração do idioma russo para o idioma português realizada por Prestes (2010).
} 
O quarto capítulo apresenta a metodologia que consiste em duas etapas: o ensaio metodológico, que teve o propósito de "testar" os instrumentos de pesquisa, e a segunda etapa, a "nova proposta metodológica", redefinida a partir dos resultados preliminares da primeira etapa.

O quinto capítulo apresenta as análises dos dados gerados das atividades desenvolvidas com os alunos do $5^{\circ}$ ano, anos iniciais do ensino fundamental, desde o período de interação até a pré-exibição do desenho animado, a sessão de desenho animado e a pós-exibição do desenho animado.

Por fim, as considerações finais foram intituladas de "As trajetórias animadas continuam...", em que a entrevistadora sintetiza as principais questões abordadas no estudo sobre a apropriação das informações científicas pelos alunos, a partir do uso do desenho animado como recurso pedagógico. 


\title{
CAPÍTULO 1
}

\section{O DESENHO ANIMADO EM CONTEXTOS EDUCATIVOS}

\author{
UM BREVE HISTÓRICO
}

Porque a arte do desenho animado conquistou um público mundial e porque os espectadores de todos os continentes se interessam por ele.

Marie-Thérèse Poncet (s.d.), em sua obra $O$ desenho animado.

Os diferentes tipos de desenho animado como animes ${ }^{8}$, adultos e infantis, permitem que espectadores de faixas etárias distintas divirtam-se com eles. Atualmente, existem canais televisivos fechados que transmitem os desenhos animados produzidos nas décadas de 1960 até $1990^{9}$, que são memoráveis para aqueles indivíduos que tiveram contato com eles. Pica-pau (EUA, 1957) ${ }^{10}$, Scooby-Doo (EUA, 1969), Tom e Jerry (EUA, 1975), Os Smurfs (EUA, 1981), Os Jetsons (EUA, 1985), Meu querido Pônei (EUA, 1986), Caverna do Dragão (EUA, 1983), Cavaleiros do Zodíaco (Japão, 1986), Digimon (Japão, 1999) são exemplos de desenhos animados que marcaram esse período.

E por que essa arte atrai públicos tão diferentes? As hipóteses podem ser referentes às características dos desenhos animados, como as imagens em movimentos, a dinâmica das narrativas e a variedade de cores e formas tanto de personagens quanto de cenários, que captam a atenção dos telespectadores e estimulam a imaginação. Essas características possibilitam criar mundos antes inimagináveis, explorando o irreal e o surreal.

A invenção de novas técnicas de produção de desenhos animados, como a animação digital, proporcionou uma verdadeira explosão de animações de diferentes tipos e gêneros, como filmes de animação (curta e longa-metragem), vinhetas de propagandas publicitárias, clipes, infográficos interativos, etc.

\footnotetext{
${ }^{8}$ Desenhos animados japoneses.

9 O destaque para esse período (1960-1990) deve-se ao fato de que, na década de 1960, foram introduzidos os desenhos animados coloridos.

${ }^{10}$ Optou-se por citar o local e o ano de produção dos desenhos animados e utilizou-se as seguintes fontes para a consulta: o sítio eletrônico Internet Movie Database- IMDb (http://www.imdb.com) e PEREIRA (2010).
} 
Em função do nosso objeto de estudo, o desenho animado, buscou-se compreender o conceito, o histórico de sua origem e o uso em diferentes contextos relacionados à educação. Portanto, a partir da definição de desenho animado, apresentaremos as características desse tipo de arte que podem contribuir para o ensinoaprendizagem de conceitos e, consequentemente, o uso como recurso pedagógico.

\subsection{Da ilusão do movimento à computação gráfica}

O desenho animado é um tipo de animação, a técnica e a estética utilizam como referência a história da arte, que passa do uso de técnicas artesanais (animação clássica) até o advento de tecnologias recentes, como a computação gráfica. Para a compreensão deste processo de criação de animações, será apresentado um breve histórico do desenho animado, sua origem e suas primeiras técnicas de produção.

A palavra animação é derivada do verbo latino animare, que significa "dar vida a”. Segundo Barbosa Júnior (2005, p. 29), a animação consiste na ilusão do movimento por meio da rápida sucessão de imagens e o seu desenvolvimento "requeria um elevado grau de desenvolvimento científico e técnico para ser viabilizada enquanto arte - o que só vai acontecer no início do século XX”. Conforme Perisic (1979), a animação é uma maneira de criar uma ilusão e de dar vida aos objetos inanimados, sejam eles reais, sejam eles simples desenhos.

A partir do resgate histórico, optou-se por distinguir três princípios importantes para o surgimento da animação: o princípio da forma do desenho gráfico, que, com a combinação de diferentes técnicas, resulta na impressão do movimento; o princípio do surgimento da fotografia, que permitiu a criação de dispositivos; e o princípio das imagens digitais, que revolucionaram as técnicas de produção de animação. Esses princípios se resumem em inventos que permitiram a utilização de diferentes técnicas para a produção de imagens em movimento que resultam em uma grande variedade de animações com distintas finalidades.

O primeiro princípio da animação remonta à forma do desenho gráfico resultado da impressão do movimento por meio da percepção visual. Autores como Madsen (1969) e Halas e Manvell (1971) sugerem que o registro das pinturas rupestres das Cavernas de Altamira (Espanha) (fig. 1) e Lascaux (França) sejam o princípio da animação, por criarem a impressão da imagem em movimento por meio da percepção visual. No Brasil, as pinturas rupestres das Cavernas do Parque Nacional da Serra da 
Capivara (Piauí, Brasil) simulam um movimento, por exemplo, a Caçada da onça ${ }^{11}$ (fig. $1)$.
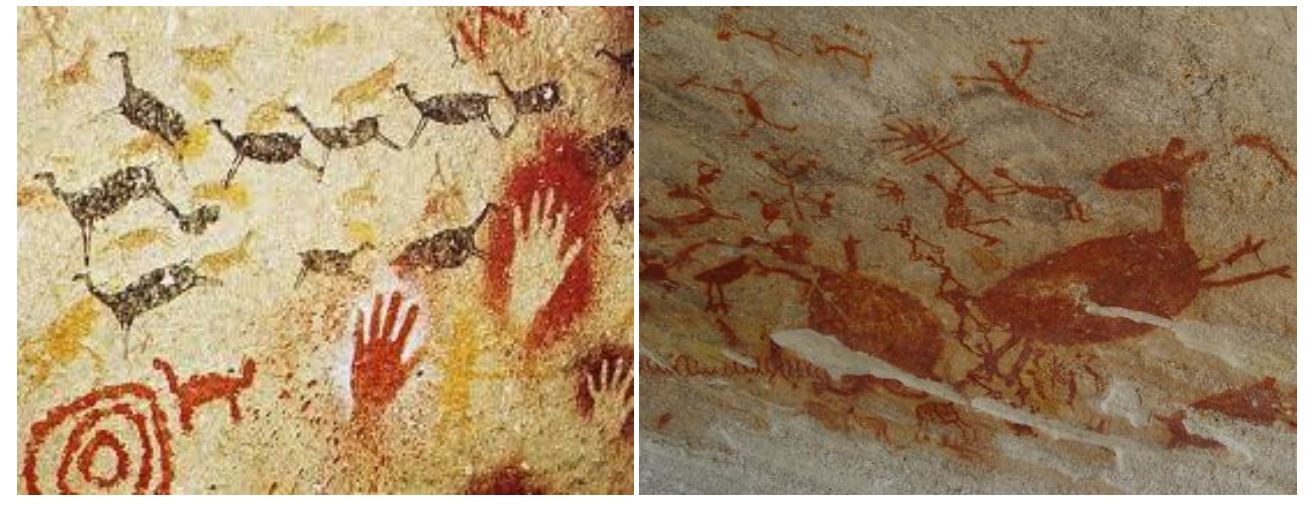

Figura 1. Pinturas rupestres da Caverna de Altamira, Espanha, e pinturas rupestres no Brasil, respectivamente. Fonte: http://www.fmanha.com.br (Caverna de Altamira); http://fumdham.org.br (Caçada da onça). Acesso em: 31 jul. 2012.

A descoberta das pinturas rupestres ocorreu em 1879. Strickland e Boswell (1999) relatam o momento da descoberta do "tesouro da arte pré-histórica na Caverna de Altamira":

[...] Marcelino de Sautola foi explorar as cavernas de Altamira, acompanhado de sua filha pequena. Como o teto ficava a poucos centímetros de sua cabeça, ele não enxergava o que estava imediatamente acima, mas, de uma perspectiva da menina, viam-se animais maravilhosos que pareciam corcovear no teto da caverna. Embora Marcelino estivesse convencido de que eram pinturas préhistóricas, arqueólogos céticos declararam que eram forjadas. Somente depois que os franceses descobriram pinturas similares, parcialmente obscurecidas por milênios de depósitos minerais, é que as pinturas de Altamira foram consideradas autênticas. Atualmente, são reconhecidas como um dos mais espetaculares achados na história da arte (STRICKLAND; BOSWELL, 1999, p. 4).

As pinturas rupestres dos animais no teto da caverna aparentavam simular um movimento na perspectiva da criança, esses desenhos foram considerados como o princípio da animação. Nesteriuk (2011) ressalta que outros historiadores da animação, como Donald Crafton, Giannalberto Bendazzi e Howard Beckerman, incluem, além deste, outros registros históricos referentes aos princípios da animação, destacando as cerâmicas do Antigo Egito, a tapeçaria da Pérsia Antiga, passando pelo teatro de formas animadas no Oriente até a invenção dos brinquedos óticos - por exemplo, o thaumatrópio - na Europa Moderna.

\footnotetext{
${ }^{11}$ A pintura rupreste pertence ao Sítio Arqueológico Toca da Entrada do Pajaú, nas cavernas localizadas no Parque Nacional da Serra da Capivara (Piauí, Brasil).
} 
O segundo princípio da animação remonta à invenção da câmara escura ${ }^{12}$ no século XVI, que projetava imagens externas dentro de um quarto escuro. A partir da criação da câmara escura, surgiu a fotografia no século XVII. Maciel e Venturelli (2008, p. 27) destacam que a invenção da fotografia "de certo modo abriu novos caminhos para o imaginário artístico, ampliando ainda mais as possibilidades de criação de novas imagens, como a possibilidade da incorporação de movimentos e sons".

A lanterna mágica (fig.2) é um invento precursor da animação, criada por Athanasius Kircher ${ }^{13}$, que publicou um livro intitulado A grande arte da luz e da sombra, em 1646. A lanterna mágica original de 1640 é conservada no Museu Kirchenerium de Roma (MORENO, 1978). De acordo com Barbosa Júnior (2005, p. 30, grifo do autor), a lanterna mágica "tratava-se de uma caixa com uma fonte de luz e um espelho curvo em seu interior, um equipamento simples que possibilitava a projeção de slides pintados em lâminas de vidro".

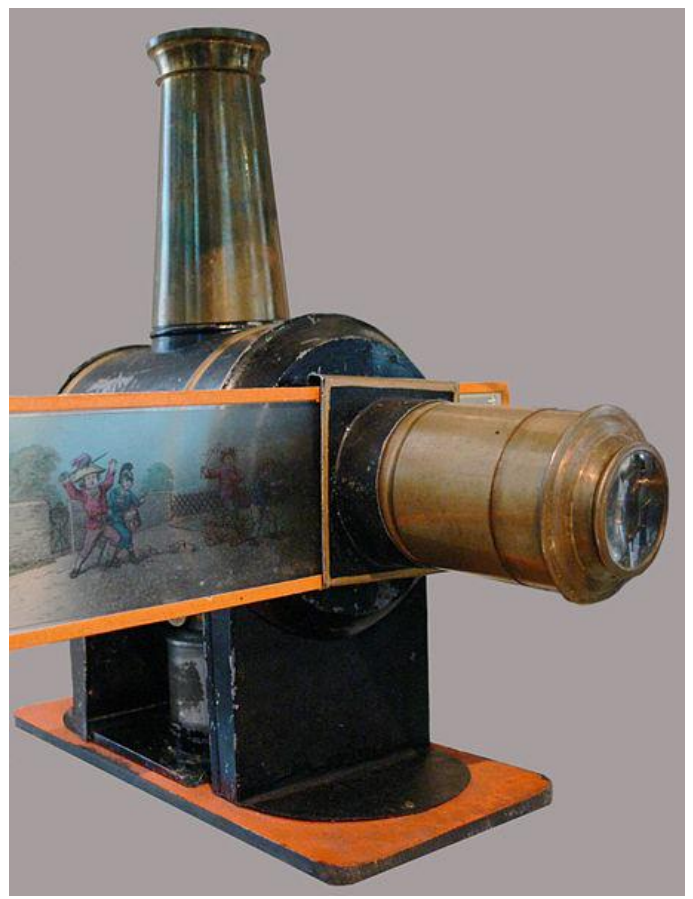

Figura 2. Lanterna Mágica.Fonte:http://commons.wikimedia.org/. Acesso em: 5 jun. 2015.

A primeira exibição animada utilizou um objeto similar à lanterna mágica de Athanasius Kircher, concebido pelo cientista holandês Pieter van Musschenbroek, que consistia em um disco giratório que projetava imagens em sequência e simulava a ilusão de movimento.

\footnotetext{
${ }^{12}$ De acordo com Maciel e Venturelli (2008), a câmara escura era composta por uma caixa preta com um simples buraco de agulha. Esta câmara era denominada de sténopé, ela permitia que a luz projetasse a imagem da paisagem local em seu interior.

${ }^{13}$ Jesuíta, matemático e físico alemão.
} 
Em1736, ele assombrou um visitante com imagens de um moinho de vento com suas pás em rotação, um homem tirando o chapéu, uma mulher curvando-se em cumprimento. Musschenbroek, posteriormente, incrementa seu aparelho usando múltiplas lanternas e imagens sincronizadas, para apresentar visões mais elaboradas. Era a primeira exibição animada (SOLOMON, 1994 apud BARBOSA JÚNIOR, 2005, p. 31).

A partir da lanterna mágica, outros inventos surgiram para criar a ilusão de que os desenhos estavam em movimento, como o teatro mágico, o taumatrópio (taumatroscópio), o fenaquistoscópio, o zootrópio e o praxinoscópio. O taumatrópio foi inventado por Peter M. Roget, físico britânico, em 1824. O invento consiste em um disco de papelão com uma imagem de cada lado perfurado nas laterais para colocar um pedaço de fio de barbante de cada lado. Ao puxar o fio com os dedos rapidamente, ocorre a fusão das imagens, resultando em uma imagem única, como pode ser visto na figura 3 .

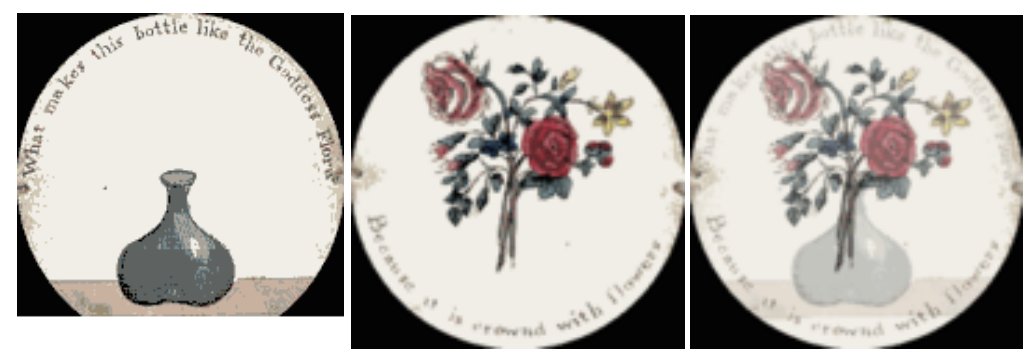

Figura 3. Taumatrópio. Fonte: http://commons.wikimedia.org/. Acesso em: 15 dez. 2013.

De acordo com Maciel e Venturelli (2008), as exibições das sessões, ou seja, as projeções das imagens para o público, ficaram conhecidas como teatro de sombras. Os autores destacam que a animação surgiu por meio da adaptação da lanterna mágica acoplada em um carrinho que deslizava em um trilho por trás de uma tela de tecido. As exibições ficaram conhecidas como fantasmagories. Essas exibições foram criadas por Etienne Gaspard Robert, no ano de 1794, em que os espetáculos eram denominados Fantasmagories, entretenimento "que obteve estrondoso sucesso, ficando anos em cartaz" (SOLOMON, 1994 apud BARBOSA JÚNIOR, 2005, p. 31).

Em 1829, Joseph-Anthonie F. Plateau, físico belga, inventou o dispositivo denominado de fenaquistoscópio (ocorrem outras variações como fenacistoscópio e fenacistiscópio), que consiste em uma placa circular com imagens de pessoas ou objetos em diferentes posições localizadas na borda. Quando a placa é girada em frente a um espelho, produz uma imagem em movimento (fig. 4). Estes inventos proporcionaram o desenvolvimento das primeiras "técnicas de animação" (COELHO, 2000). 


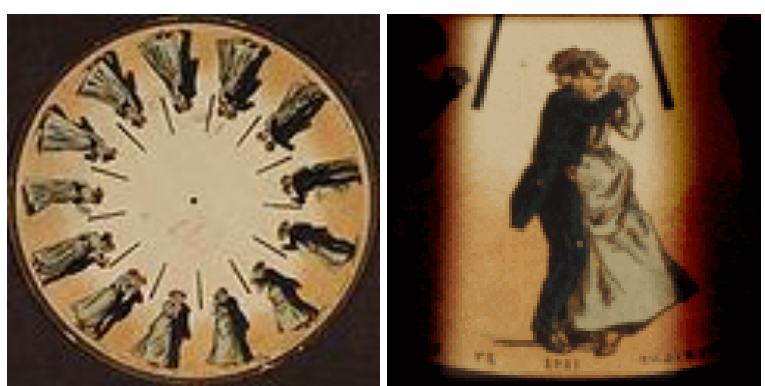

Figura 4. Fenaquistoscópio. Fonte: http://commons.wikimedia.org/wiki/. Acesso em: 21 dez. 2013.

O zootrópio (fig. 5), criado pelo matemático William George Horner, em 1834, consiste em um tambor circular com frestas recortadas. As figuras estão dispostas na parte interna do tambor, que, ao ser girado, produz uma imagem que cria a ilusão de movimento. O zootrópio também é denominado de "roda da vida" (PONCET, s.d., p. 23).

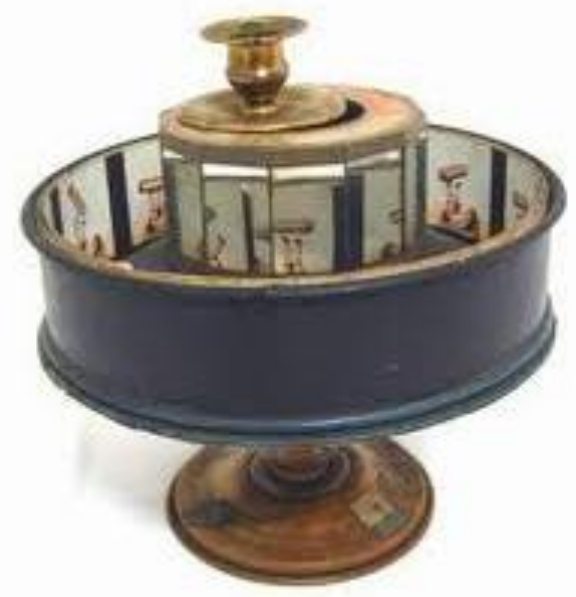

Figura 5. Zootrópio. Fonte: https://encrypted.tbn1.Gstatic.com/. Acesso em: 15 dez. 2013.

Após o desenvolvimento de diversas técnicas, o primeiro desenho animado foi inventado pelo francês Émile Reynaud, que concebeu o praxinoscópio (fig. 6), sistema de animação de dozeimagens, e os filmes de aproximadamente quinhentasa seiscentasimagens, projetado no seu próprio teatro óptico, sistema próximo do moderno projetor de filme. De acordo com Coelho (2000), o teatro óptico foi inaugurado em outubro de 1892 e funcionava dentro do Museu Grévin. Este é um museu de cera, localizado na França, inaugurado em 1882 pelo jornalista Arthur Meyer. O Museu Grévin é um dos museus de cera mais antigos da Europa. 


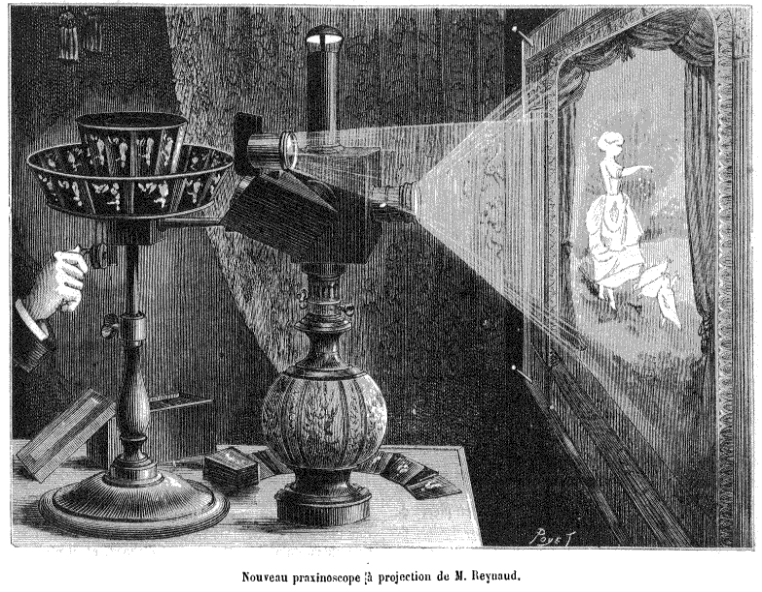

Figura 6. Praxinoscópio. Fonte: http://commons.wikimedia.org/. Acesso em: 23 jan. 2014.

Poncet (s.d.) ${ }^{14}$ destaca que Émile Reynaud, antes mesmo da criação do cinema pelos irmãos Lumière, realizou a análise imagem por imagem de um movimento e a síntese deste movimento é apresentada em imagens animadas por meio do praxinoscópio, em 1877. Mas, conforme a autora, Reynaud não se contentou somente com as imagens em movimento e, por meio do teatro óptico, conta histórias com personagens pintadas e projeta-as no Museu Grévin (fig. 7).

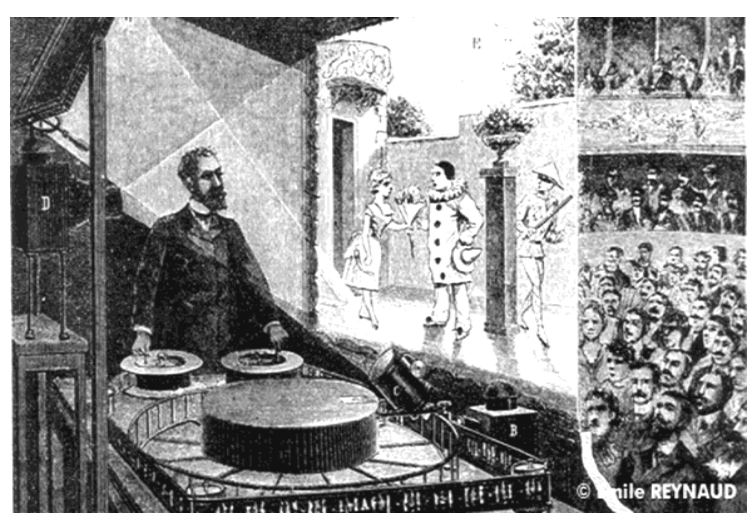

Figura 7. Teatro óptico, de Émile Reynaud. Fonte: http://commons.wikimedia.org/. Acesso em: 15 ago. 2013.

De acordo com Barbosa Júnior (2005), os irmãos Lumière criaram o cinematógrafo, o primeiro projetor de filmes em que eles realizaram a primeira exibição de fotografias animadas em 1895. O cinematógrafo é um aparelho aperfeiçoado do kinetógrafo de Thomas Edison, com a vantagem de filmar e projetar ao mesmo tempo.

A utilização da câmara dos irmãos Lumière para a filmagem dos desenhos e a sua projeção numa tela resultou em uma técnica mais moderna desenvolvida por Émile Cohl (PONCET, s.d.). O primeiro desenho animado, exibido por meio de um projetor

\footnotetext{
${ }^{14} \mathrm{Na}$ versão no idioma português não consta o ano de publicação, mas no título original,Le Dessine anime, o ano refere-se a 1966.
} 
de filme "moderno", foi criado pelo francês Émile Cohl em 1908. O desenho, intitulado de Fantasmagorie $^{15}$ (fig. 8), tinha apenas dois minutos e foi exibido no Theatre Gymnase, em Paris, França (MADSEN, 1969; COELHO, 2000).

Barbosa Júnior (2005) destaca que Fantasmagorie é "o primeiro desenho animado de verdade, com seus dois minutos fotografados frame a frame e apresentando características estilísticas bem definidas". O frame a frame significa que o desenho foi fotografado quadro a quadro e Cohl ainda descobriu que poderia fotografar cada quadro duas vezes, o que implicou na continuidade de movimento. Antes de Fantasmagorie, Stuart Blackton elabora o desenho Humorous Phases of Funny Faces, uma animação realizada quadro a quadro, mas que não apresenta uma continuidade de movimento e nem a relação entre os quadros (BARBOSA JÚNIOR, 2005).

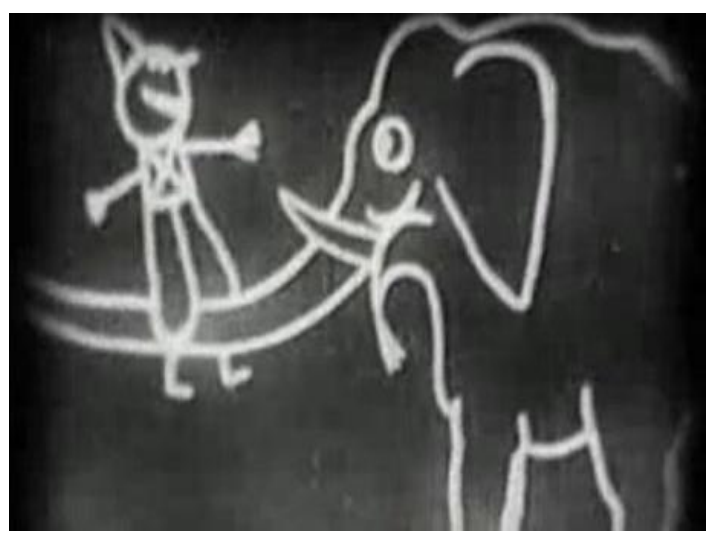

Figura 8. Imagem de um trecho do desenho animado Fantasmagorie. Fonte: http://www.findingdulcinea.com. Acesso em 13 set. 2012.

O desenho animado é somente um tipo de animação. Poncet (s.d.) define o que se entende por desenho animado:

O desenho animado é a descrição de uma história (ou de um tema narrado), cuja composição representa uma continuidade de desenhos concebidos especialmente para serem fotografados segundo as regras do processo imagem por imagem, a fim de se obter uma sucessão de fotografias animadas em filme, cujos assuntos se movem. Devido à montagem, elas são projectadas na tela, sob a forma de um desenvolvimento contínuo e vivo, animado (PONCET, s.d., p. 32).

Atualmente, o desenho animado é o resultado de diversos instrumentos e técnicas ${ }^{16}$ para a produção, que combinam a simulação do movimento com a projeção de imagens. Atualmente, o stop motion é a mais utilizada, esta técnica de animação

${ }^{15} \mathrm{O}$ desenho original Fantasmagorie encontra-se disponível no sítio eletrônico: https://www.youtube.com/watch?v=6FQCESiyqaM.

${ }^{16}$ Neste trabalho a palavra técnica será definida como o conjunto de instrumentos que possibilitem executar determinada ação. 
fotograma a fotograma (quadro a quadro) faz uso de recursos como a máquina de filmar, a máquina fotográfica ou o computador (COELHO, 2000). Além do stop motion, diferentes técnicas como o acetato (desenho sobre folhas de celuloide transparente), a rotoscopia (desenho por cima da imagem previamente registrada) (fig. 9) e as mais recentes, como a animação digital (fig. 9) (BARBOSA JÚNIOR, 2005; NESTERIUK, 2010).

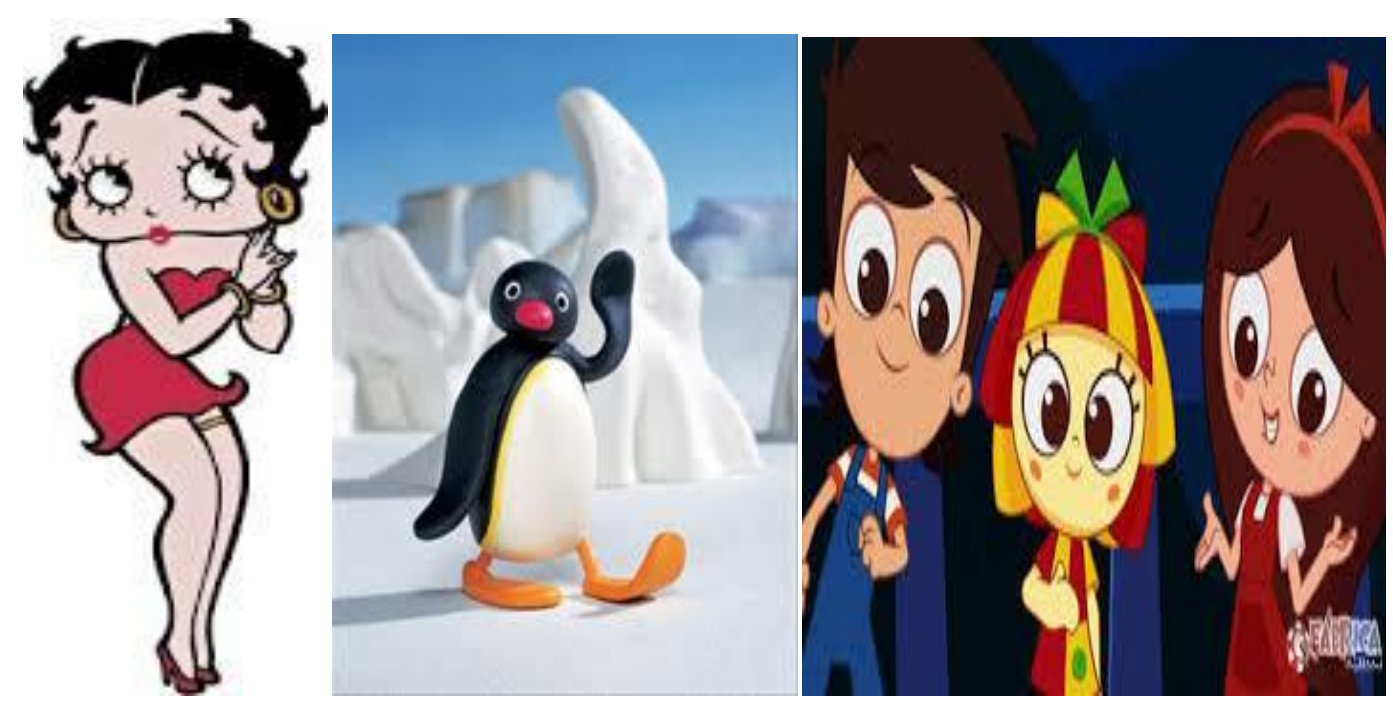

Figura 9. Exemplos de diferentes técnicas como a rotoscopia (Betty Boop, 1930), o stop motion (Pingu, 1986) e a animação digital (Sítio do Pica Pau Amarelo, 2010). Fonte: http://www.google.com.br. Acesso em: 10 set. 2014.

Na década de 1920, a primeira personagem de desenho animado foi o Gato Félix (fig. 10), criado pelo cartunista estadunidense Otto Messmer. Após o Gato Félix, outras personagens foram criadas, como a Betty Boop (EUA, 1930) (fig. 10), o Super-Homem (EUA, 1941), o Pica-pau (EUA, 1957) (fig. 10) e o Popeye (EUA, 1960) (PEREIRA, 2010).

Nesteriuk (2010) destaca que a história da animação brasileira se inicia em 1907, com as charges animadas realizadas por Raul Pederneiras para terminar a exibição de cinejornais projetados nas salas de cinema. Após três anos, Alberto Botelho e Alberto Moreira lançam o curta de animação Paz e Amor, uma crítica à campanha civilista do governo regente da época, do presidente Nilo Peçanha ${ }^{17}$.

\footnotetext{
${ }^{17}$ Nilo Peçanha foi o primeiro presidente mulato do Brasil e assumiu o governo após o falecimento do presidente Afonso Pena, sendo o mandato cumprido entre junho de 1909 e novembro de 1910.
} 

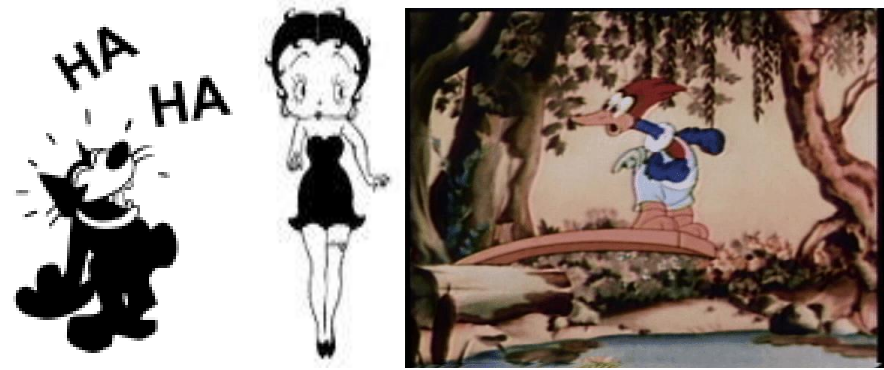

Figura 10. Gato Félix, Betty Boop e Pica-pau, respectivamente. Fonte: http://www. commons.wikimedia.org. Acesso em: 2 fev. 2015.

O cinema de animação inclui a produção tanto de filmes (curta e longametragem) quanto de desenhos animados. Para a Association Internacionale du Film d'Animation - ASIFA, França, entende-se por cinema de animação como "toda criação cinematográfica realizada, imagem por imagem" e explica a diferença do cinema de tomada direta:

O cinema de animação difere do cinema de tomada direta pelo fato deste proceder de uma análise mecânica por meio da fotografia, de fatos semelhantes àqueles que serão reconstituídos na tela, enquanto o cinema de animação cria os fatos por outros meios além do registro automático. Num filme de animação, os fatos têm lugar, pela primeira vez, na tela (ASIFA, 1961 apud MORENO, 1978, p. 8).

O primeiro filme de animação ${ }^{18}$ (longa-metragem), Branca de Neve e os sete anões, produzido pelos Estúdios Walt Disney, em 1937, levou três anos para ser produzido (BRUZZO, 1994). A história é baseada nos contos de fada dos irmãos Grimm. O roteiro do filme começou a ser escrito em 1934 e foi concluído em 1935, ano em que se iniciou a produção do filme (NESTERIUK, 2011). De acordo com Moreno (1978), o primeiro filme de animação brasileira foi Kaiser (Brasil, 1917), de Álvaro Marins (apelidado de Seth). O primeiro filme de animação colorido produzido no Brasil foi Sinfonia Amazônica ${ }^{19}$ (Brasil, 1953), de Anélio Lattini Filho. O filme conta sete lendas amazônicas como: Noite; Formação do Rio Amazonas; Fogo; Caipora; Jabuti e a Onça; Iara; e Arco-íris. Nesteriuk (2011, p. 111) destaca que "Lattini chegou a trabalhar vinte horas por dia para concluir o filme" composto de quinhentos mil desenhos diferentes.

\footnotetext{
${ }^{18}$ Nesteriuk (2011) destaca que, ao contrário do que alguns autores afirmam, este não é o primeiro filme de longa-metragem de animação. Os primeiros longas de animação, El Apostól (1917) e Peludópolis (1931), sendo este último sonorizado, foram dirigidos por Quirino Cristiani, italiano radicado na Argentina.

${ }^{19}$ De acordo com Nesteriuk (2011, p. 111), "o negativo encontra-se conservado na Cinemateca Brasileira e uma empresa do Rio de Janeiro está captando recursos para restaurar e digitalizar essa obra pioneira da animação brasileira".
} 
Segundo este autor, os filmes de animação produzidos (curtas-metragens) eram exibidos nos chamados nickelodeons, pequenas salas para a projeção de filmes de diferentes temáticas e gêneros. Estas salas posteriormente acabaram sendo substituídas pelas salas de cinema, que se diferenciavam por serem maiores e por possibilitarem a projeção de filmes de longa-metragem (NESTERIUK, 2011). Nesse contexto, surgem as séries de animações em função da produção de mais de um episódio de personagens que cativavam o público. $\mathrm{O}$ autor explica a ocorrência desse fato:

\begin{abstract}
A partir do sucesso dos filmes unitários de animação de curtametragem (com duração média de dez e máxima de 30 minutos), abriu-se espaço para a produção e exibição de séries de animação. Ao invés de se assistir a um curta unitário, a ideia era que universos e personagens que tivessem boa aceitação pudessem cativar o público e fazê-lo retornar e assistir a um novo episódio. Ao mesmo tempo, o desenvolvimento de uma série, ao invés de várias curtas unitários, permite a otimização de seu processo de produção por meio do aproveitamento de elementos previamente elaborados (NESTERIUK, 2011, p. 27).
\end{abstract}

A produção das séries de animações inicia-se na primeira década do século $\mathrm{XX}$, sendo exibidas tanto nos nickelodeons quanto nas salas de cinema. Essa produção sofre uma queda "quando passam a ser produzidas, em sua quase totalidade, diretamente para a televisão" (NESTERIUK, 2011, p. 28).

No Brasil, a chegada da televisão ocorreu na década de 1950. Pica-pau (EUA, 1940) foi o primeiro desenho animado exibido na televisão brasileira, na extinta TV Tupi, primeira emissora de televisão, inaugurada em 18 de setembro de 1950 (NESTERIUK, 2011). Os desenhos animados exibidos nas emissoras brasileiras eram importados, principalmente dos Estados Unidos, sendo esta época marcada pela industrialização da animação. Este país produzia séries em larga escala para atender a demanda e comercializar para outros países. De acordo com Pereira (2010, p. 140), “os desenhos eram exibidos em cópias preto e branco, mesmo que o original fosse colorido". O autor destaca que Os Brasinhas no Espaço (EUA, 1966), produzido pelo Estúdio Hanna-Barbera, foi o primeiro desenho animado colorido a ser exibido, em setembro de 1972, ano que marca o início das transmissões em cores no Brasil (PEREIRA, 2010). 
A Turma da Mônica (Brasil, 1985) é a primeira série de desenho animado brasileiro para fins comerciais produzida pelos Estúdios Maurício de Sousa ${ }^{20}$ (NESTERIUK, 2011). Segundo este autor, os desenhos animados são séries de animação para a televisão, e ainda ressalta que "atualmente, a presença da animação no cinema se restringe aos longas e curtas-metragens, estes últimos exibidos em festivais, mostras" (Idem, p. 28).

Nesse contexto, convém destacar a realização do I Festival Internacional de Cinema de Animação no Brasil, que ocorreu em 1965, no Museu de Arte de São Paulo MASP. Ao total, dez obras brasileiras foram apresentadas no festival, o que proporcionou aos animadores o intercâmbio artístico e cultural, além da exibição de animações produzidas em outros países (NESTERIUK, 2011). O festival despertou nos animadores brasileiros a criação de grupos, de centros de estudos e de diversas mostras.

Destaca-se o Núcleo de Cinema de Animação de Campinas - NCAC como um dos núcleos mais antigos, fundado em 1975 por dois precursores da animação brasileira, Wilson Lazzaretti e Mauricio Squarizzi. Segundo Nesteriuk (2011, p. 113), o Núcleo realiza "diversas obras e atividades de ensino e educação relacionados à animação em todo país, sobretudo junto às crianças". O primeiro longa-metragem produzido pelo NCAC, História antes de uma História (Brasil, 2013), narra a história do Dr. Ka (fig. 11), um senhor sábio que aprende a criar uma animação utilizando os seus próprios desenhos.

A lista de animadores brasileiros é vasta e inclui Alê Abreu, Marcelo de Moura, Marcos Magalhães, Mariana Caltabiano, Marta Machado, Raquel Coelho, Walbercy Ribas, Carlos Saldanha ${ }^{21}$, entre outros. Os animadores Aida Queiroz, César Coelho e Léa Zagury idealizaram o principal festival de animação brasileira e participam da organização deste festival desde 1993, o ANIMA MUNDI - Festival Internacional de Animação do Brasil, que ocorre anualmente nas capitais do Rio de Janeiro e de São Paulo (QUEIROZ, 1993) e em outros estados brasileiros ocorrem mostras itinerantes.

\footnotetext{
${ }^{20}$ De acordo com Pereira (2010, p. 144), Mauricio de Sousa criou o estúdio de Animação Black \& White, que realizou oito longas-metragens, entre eles $O$ Natal da Turma da Mônica, que teve uma repercussão positiva. A equipe aproveitou o roteiro para produzir a série que foi ao ar na década de 1980.

${ }^{21} \mathrm{O}$ brasileiro Carlos Saldanha é animador, produtor, diretor e dublador. Atualmente é referência internacional em animação. Em 2002, Saldanha foi codiretor do filme A Era do Gelo (EUA, 2002), que ganhou o Oscar de melhor animação em 2003, e o seu último trabalho dirigido foi Rio 2 (EUA, 2014).
} 


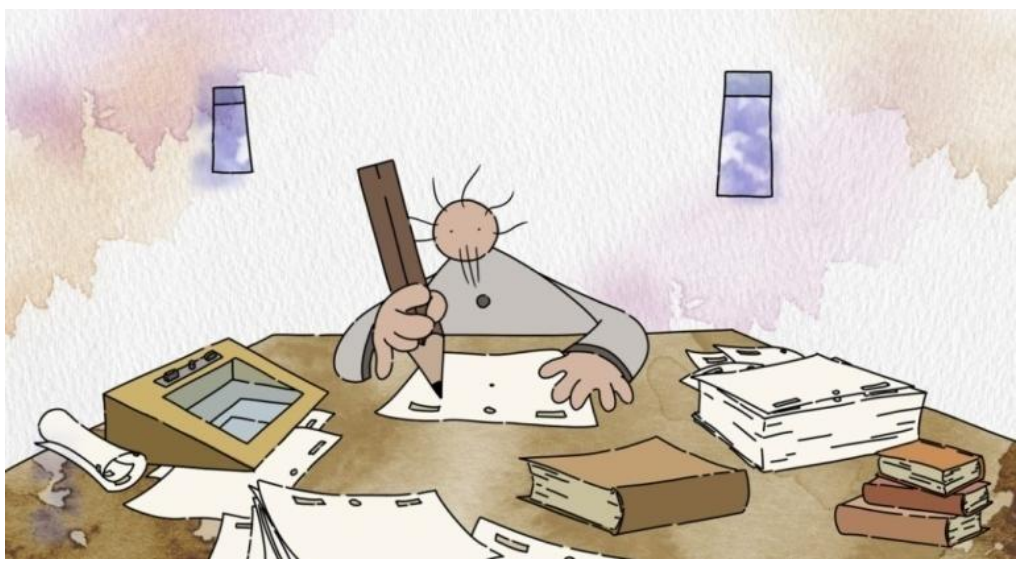

Figura 11. Cena do longa-metragem História antes de uma História, produzido pelo NCAC. Fonte: http://animamundi.com.br/. Acesso em: 5 jun. 2015.

De acordo com Nesteriuk (2011), Aida Queiroz e César Coelho compõem a nova geração de animadores brasileiros resultante da formação do intercâmbio cultural e tecnológico firmado na parceria entre Brasil e Canadá, na década de 1980. A parceria promoveu a formação de animadores, a criação do Centro Técnico do Audiovisual vinculado ao Ministério da Cultura - e o desenvolvimento de núcleos regionais nos estados brasileiros.

Além do ANIMA MUNDI, outro festival que ocorre anualmente no Brasil é o Festival Internacional de Animação de Horror, conhecido como ANIMALDIÇOADOS, e que está na sua quinta edição. O Festival Internacional de Cinema Infantil - FICI também tem representatividade da animação, desde 2003, ocorre com exibições de filmes produzidos nacional e internacionalmente nas salas de cinema da rede Cinemark. $\mathrm{Na}$ última edição do festival, realizada em 2014, o evento ocorreu em seis cidades brasileiras e, de acordo com as informações disponibilizadas em seu sítio eletrônico ${ }^{22}$, levou mais de um milhão de crianças às salas de cinema e contou com a exibição de cem filmes de vinte e quatro países.

Ao retomar os princípios da animação elencados neste estudo, destaca-se o terceiro e último princípio que se refere às imagens digitais que revolucionaram as técnicas de produção de animação. A realização de filmes de animação é apenas um aspecto da animação em geral e que provavelmente é o tipo mais conhecido (PERISIC, 1979). A tecnologia mais recente é a computação gráfica. Os filmes podem ser filmados em 2D (duas dimensões) ou em 3D (três dimensões).

O primeiro filme de animação criado por computação gráfica foi Toy Story (EUA, 1995) (fig. 12) e, no ano seguinte, o Brasil produziu Cassiopéia (Brasil, 1996)

\footnotetext{
${ }^{22}$ Disponível em:<http://www.festivaldecinemainfantil.com.br>. Acesso em: 15 jun. 2015.
} 
(fig. 12). Posteriormente, com as produções que utilizam a computação gráfica, surgiu Brasil Animado (Brasil, 2010) (fig. 12), o primeiro filme brasileiro de animação em 3D. Pereira (2010, p. 210) destaca que, antes dessas produções serem exibidas nas salas de cinema, a produtora canadense Mainframe Entertainment criou ReBoot (Canadá, 1994), a primeira série "totalmente animada por computação gráfica" e transmitida por canais televisivos.
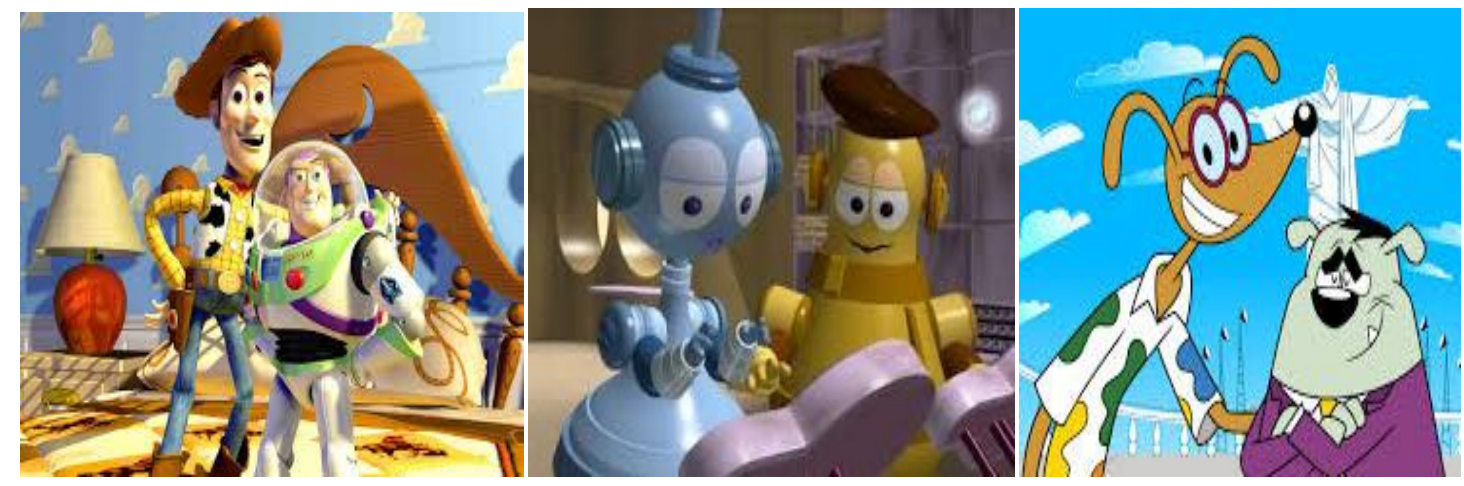

Figura 12. Animações criadas por computação gráfica como Toy Story, Cassiopéia e Brasil Animado, respectivamente. Fonte: http://findwallpaper.info (Toy Story); http://animablog.wordpress.com (Cassiopéia).

As animações, desenhos ou filmes, são utilizadas nas campanhas publicitárias como a famosa baratinha Rodox (fig. 13), o baianinho das Casas Bahia (fig. 13) e a menina da margarina Claybom (fig. 13), sendo estes criados na década de 1970 e 1980. Além das campanhas publicitárias, as animações também podem ser utilizadas na criação de cartões virtuais, animações institucionais de caráter cultural ou didático.

Em relação à produção brasileira, existem aproximadamente sessenta e cinco estúdios de animação no Brasil, entre eles: Art C, Arwel Art, Animar, Estúdio Maurício de Sousa e Start Desenhos Animados. Algumas produtoras tiveram iniciativas pioneiras na criação e na produção de desenhos animados para os canais televisivos (abertos e fechados ${ }^{23}$ ), são exemplos: Escola para cachorro (Brasil/Canadá, 2009), Meu Amigãozão (Brasil/Canadá, 2010), Peixonauta (Brasil, 2009), Princesas do Mar (Austrália/Brasil/Espanha, 2008) e Tromba trem (Brasil, 2010). Entre os desenhos animados citados, alguns foram produzidos com objetivos didáticos, educativos ou de divulgação científica. Portanto, o próximo subcapítulo tem por objetivo resgatar a história dos desenhos animados no contexto educativo.

23 Conforme a Lei $n^{\circ} 12.485$, de 12 de setembro de 2011, é determinada uma cota da produção independente de desenhos animados brasileiros na programação dos canais de TV por assinatura, para incentivar e desenvolver o mercado interno de produção de animações brasileiras. 

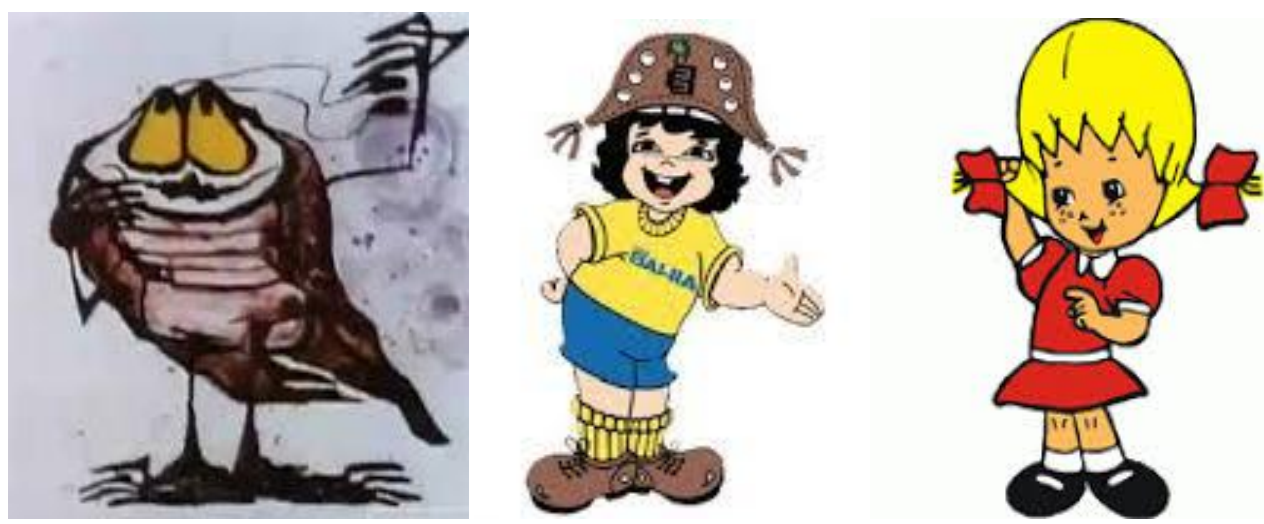

Figura 13. Baratinha Rodox, Baianinho e Menina da Claybom, respectivamente. Fonte: http//:www.blogcitario.blog.br (Baratinha Rodox); http//:www.mundodasmarcas.blogspot.com (Baianinho), http//:www.vassourando.com (menina da Claybom ). Acesso em: 2 fev. 2015.

\subsection{Desenho animado e Educação}

No catálogo da exposição Movie-se ${ }^{24}$, o artigo de Greg Hilty, intitulado Objeto, sonho e imagem na animação, indica que, desde os primeiros projetores da lanterna mágica, ocorriam exibições de cunho educativo. Além do uso da lanterna mágica, os estudos sobre a locomoção humana e animal, de Eadweard Muybridge, possibilitaram posteriormente o desenvolvimento de "técnicas" como os slides de vidro pintados à mão, e esses, quando eram colocados no zoopraxiscópio, produziam filmes animados em exibições itinerantes e instrutivas (HILTY, 2012).

Com o advento da câmara dos irmãos Lumière, Poncet (s.d.) destaca que as sessões de cinema que ocorriam na década de 1950 eram compostas por um jornal de atualidades, um documentário (ou um desenho animado) e um filme de longametragem. A partir da programação dessas sessões, demonstrou-se a ascensão do desenho animado e da animação e, nas palavras da autora, revelaram "a sua incursão em diferentes disciplinas educativas e recreativas" (Idem, p. 19).

Nesteriuk (2011) registra que nessa década Zdenìk Miller lançou Krtek (em tradução livre, A Toupeira) (Tchekoslováquia, 1957), um desenho animado com o propósito de ensinar as crianças sobre o processamento do linho. A criação da personagem foi inspirada pelas fábulas de Walt Disney e o autor ainda destaca que a "ideia da personagem surgiu após seu criador tropeçar em um montinho de terra durante a caminhada" (Idem, p. 37). As toupeiras são mamíferos que vivem no subsolo e

${ }^{24}$ A exposição Movie-se: no tempo da animação, realizada no Centro Cultural do Banco do Brasil CCBB, no Rio de Janeiro e em Brasília em 2013, teve o intuito de apresentar a história da animação de uma forma cronológica e cumulativa dos últimos 150 anos. O acervo da exposição reúne desenhos e filmes de animação de artistas consagrados e contemporâneos, a curadoria é organizada pela galeria de arte Barbican Centre, de Londres. 
constroem galerias formando as tocas que habitam. A série é composta por cinquenta episódios, produzidos até 2002, exibidos com sucesso em outros países como Austrália, Índia e China.

No Brasil, as projeções que ocorriam nas sessões de cinema despertaram o interesse de pedagogos e intelectuais como Manuel Bergstrom Lourenço Filho, Fernando de Azevedo, Edgar Roquete Pinto, Jhonatas Serrano, entre outros, preocupados com a introdução dos princípios da chamada Escola Nova ${ }^{25}$ nos currículos escolares (MORETTIN, 1995). A utilização de projeções animadas esteve relacionada aos projetos de cinema educativo iniciados na década de 1920. Os principais projetos desenvolvidos foram a criação do Instituto Nacional de Cinema Educativo - INCE (1936), o projeto TV Escola (1995) e o projeto Mídias na Educação (2008), sendo estes vinculados ao Ministério da Educação.

Segundo Serrano e Venâncio-Filho (1930) a reforma do ensino no Distrito Federal, proposta por Fernando de Azevedo, previu uma reorganização geral no ensino e incluiu no seu programa a introdução do cinema educativo. Em 1927, instaurou-se uma Comissão de Cinema Educativo sob a direção imediata da Subdiretoria Técnica de Instrução Pública, que iniciou seus trabalhos com a organização da Exposição de Aparelhos de Projeção (fixa e animada), realizada em agosto de 1929.

A exposição contou com a apresentação dos filmes de projeção, a demonstração prática dos aparelhos de projeção fixa (epidiascópios) (fig. 14), a sala de projeção animada em medida reduzida (Pathé $B a b y^{26}$ ), a sala de projeções com diferentes aparelhos de medida universal, a exposição de catálogos, os opúsculos de propaganda, as notas bibliográficas referentes a livros e revistas cinematográficas e as palestras direcionadas aos professores sobre as possibilidades do cinema aplicadas ao ensino (SERRANO; VENÂNCIO-FILHO, 1930).

\footnotetext{
${ }^{25}$ Movimento de renovação dos métodos de ensino em que o foco do processo educativo passa a ser o aluno.

${ }^{26}$ Projetor de medida reduzida que usava um sistema para a projeção de filmes de $9,5 \mathrm{~mm}$.
} 


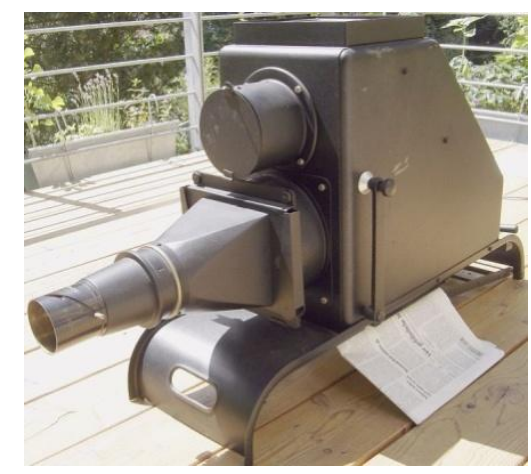

Figura 14. Epidiascópio. Fonte: http://www.wikimedia.commons.com. Acesso em: 27 jan. 2014.

A concretização do cinema educativo ocorreu após dezesseis anos do início das discussões dos educadores brasileiros para a introdução do cinema educativo. $O$ Instituto Nacional de Cinema Educativo - INCE, criado em 1936, foi o primeiro órgão oficial do governo de Getúlio Vargas planejado para o cinema, subordinado ao Ministério da Educação e Saúde Pública, cujo ministro regente era Gustavo Capanema (CARVALHAL, 2009).

De acordo com o acervo filmográfico disponibilizado no sítio eletrônico da Cinemateca Brasileira ${ }^{27}$, o INCE produziu uma série de animação denominada Alfabeto Animado $^{28}$, produzida em 1966, composta por seis episódios, em que o professor ABC (fig. 15) ensina as letras do alfabeto e as palavras da língua portuguesa. De acordo com Garcia (1967), o Alfabeto Animado, dirigido por Guy Lebrun, "é uma série de 12 desenhos animados com duração média de 3 minutos e de 12 diafilmes ${ }^{29}$ de 50 quadros aproximadamente". Segundo o autor, a criação desse desenho animado teve como objetivo produzir material audiovisual para o Plano Nacional de Alfabetização, concebido por Tarso Dutra, à época Ministro da Educação e Cultura.
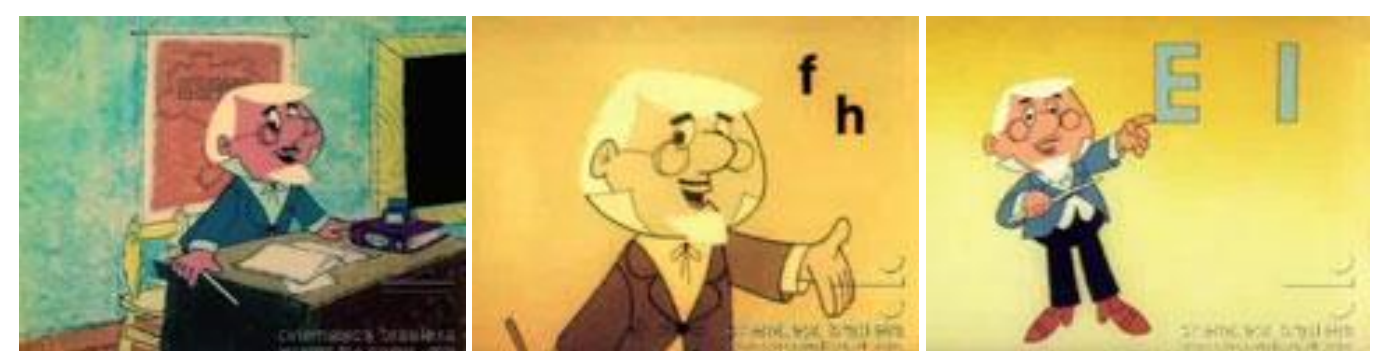

Figura 15. Professor ABC. Fonte: http://www.bcc.org.br/filmes/ince. Acesso em: 2 fev. 2015.

\footnotetext{
${ }^{27}$ Disponível em:<http://www.cinemateca.gov.br>. Acesso em: 21 nov. 2012.

${ }^{28}$ A série de animação Alfabeto Animado encontra-se disponível no Banco de Conteúdos Culturais da Cinemateca Brasileira, disponível no sítio eletrônico: http://www.bcc.org.br/ filme/detalhe/026415.

${ }^{29}$ Diafilme é uma sequência de fotografias dispostas em um filme para projeção.
} 
Entretanto, há controvérsias de que Humberto Mauro ${ }^{30}$ tenha produzido dois filmes de animação quando atuava no INCE, Dragãozinho manso (1942) e A velha a fiar (1964), que antecedem Alfabeto Animado, mas que não podem ser consideradas animações em função das técnicas utilizadas ${ }^{31}$ na elaboração dos filmes. De acordo com Ribeiro (2009), na década de 1960, iniciou-se o processo de diluição do órgão, visto que já não produzia filmes. E em 1966, após a criação do Instituto Nacional de Cinema INC, o INCE ${ }^{32}$ perde a sua autonomia e é integrado pelo novo órgão.

Com a criação da televisão, o uso de projeções em tela passa para o vídeo. Paralelamente às ações iniciadas pelo INCE, a TV Cultura foi criada em 1960, após dez anos da chegada da televisão no Brasil. Esta emissora pública possui caráter educativo e cultural. Uma versão brasileira adaptada do programa estadunidense Vila Sésamo (título original: Street Sessame) foi o primeiro programa infantil importado e exibido na TV Cultura.

Durante cerca de 40 anos, as únicas animações vistas na televisão brasileira eram criadas e produzidas no exterior, salvo raras exceções, como o extinto programa "Lanterna Mágica", apresentado por Roberto Miller na TV Cultura. Somente no início dos anos 90 é que pequenas séries de curta duração e com número limitado de episódios passaram a ser vistas, sobretudo nas emissoras públicas e educativas (NESTERIUK, 2010, p. 59).

Ainda na década de 1960, o desenhista Wilson Pinto animou e dirigiu o primeiro curta-metragem de animação em cores do Brasil encomendado pela Petrobrás, Um Rei Fabuloso $^{33}$ (Brasil, 1965) (fig. 16), que narrava a história do petróleo. O desenhista contou com a parceria de Wanda Latini (irmã de Anélio Latini, que produziu o primeiro longa-metragem colorido de animação, Sinfonia Amazônica). Durante várias décadas, o curta Um Rei Fabuloso foi exibido nas escolas públicas de todo o país.

\footnotetext{
${ }^{30}$ Cineasta, produtor e funcionário público do INCE.

${ }^{31}$ Ribeiro (2009) expõe que o filme de curta-metragem Dragãzinho Manso utiliza a técnica da trucagem e manipulação de bonecos e que, ao analisar o filme pela definição de filme de animação, proposta pela ASIFA e citada anteriormente, o autor afirma que não podemos considerar como animação, ou seja, filmado quadro a quadro em vez da filmagem ao vivo. Com relação ao outro filme, A Velha a fiar, "as imagens gravadas dividem a cena com a manipulação de bonecos com fios, onde as cenas aparecem em sincronia com a música de mesmo nome executada pelo Trio Irakitã" e o autor, ao assistir o filme, percebe que em uma cena o pau se move sozinho e "acredita que essa cena foi produzida em stop motion (sic), ou seja, quadro a quadro".

${ }^{32}$ A filmografia do INCE encontra-se disponível no sítio eletrônico da Cinemateca Brasileira, instituição pública subordinada ao Ministério da Cultura com sede na capital Rio de Janeiro.

${ }^{33}$ Atualmente, o curta-metragem Um Rei Fabuloso encontra-se disponível no sítio eletrônico https://www.youtube.com/watch?v=SyyTMq9btrQ.
} 

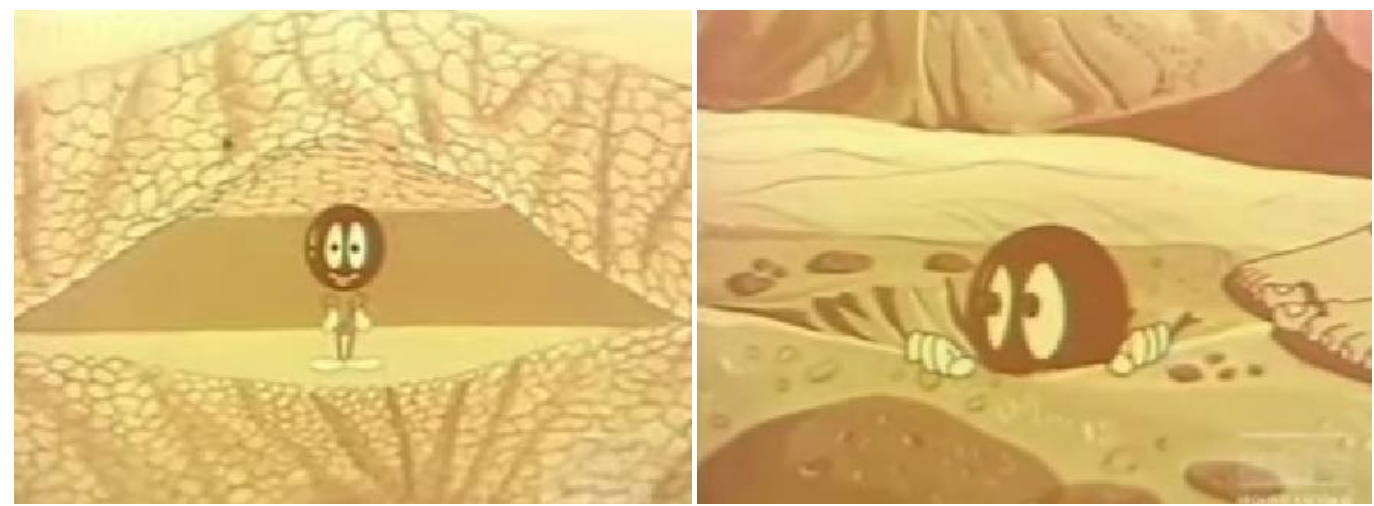

Figura 16. Cenas decupadas do curta-metragem de animação Um Rei Fabuloso.

Outro curta de animação, Zé Gotinha contra os pernas-de-pau (Brasil, 1989), produzido pelo Estúdio Otto Desenhos Animados, foi uma continuação das campanhas publicitárias de vacinação contra a paralisia infantil para fins educativos, promovida pelo Ministério da Saúde. A personagem Zé Gotinha, criada por Darlan Rosa em 1986, sofreu diversas modificações nas últimas décadas como apresenta a figura 17 a seguir.
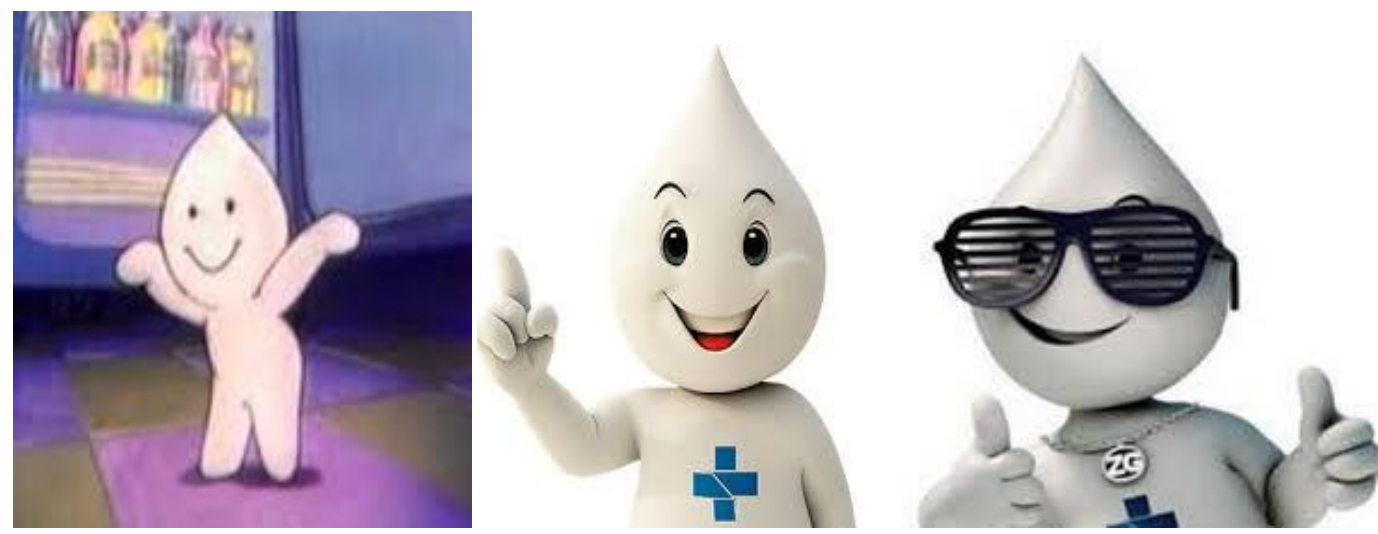

Figura 17. Diferentes personagens Zé Gotinha, desde a sua criação em 1986 até a última campanha em 2013. Fonte: http://google.com.br/images.

Além dessas animações institucionais, o Ministério da Educação produz e/ou importa animações com fins educativos para o uso nas escolas públicas do Brasil. O programa TV Escola, criado em 2000 pela Secretaria de Educação a Distância - SEED do Ministério da Educação ${ }^{34}$, é um programa de aperfeiçoamento e capacitação em serviço a distância, destinado a professores da rede pública de ensino fundamental e médio. O programa TV Escola transmite uma programação que é orientada pelos

\footnotetext{
${ }^{34}$ Atualmente, esta Secretaria foi extinta e o programa TV Escola é subordinado à Coordenação Geral de Mídias e Conteúdos Digitais da Diretoria de Formulação de Conteúdos Educacionais da Secretaria de Educação Básica- SEB do Ministério da Educação.
} 
Parâmetros Curriculares Nacionais - PCN e que pode ser gravada ${ }^{35}$ pela escola para que cada uma monte a sua videoteca e utilize o acervo como apoio para a capacitação dos professores ou como recurso didático, melhorando a qualidade do ensino na escola pública (MEDEIROS, 2002).

Atualmente, a programação do TV Escola conta com vídeos que podem ser acessados e que permitem o download no site do programa ${ }^{36}$. O intuito em citar este programa refere-se à produção e/ou importação de animações como recurso pedagógico. O acervo possui uma diversidade de animações com temas e títulos de diferentes componentes curriculares nas etapas e modalidades da Educação Básica (Educação Infantil, Ensino Fundamental, Ensino Médio e EJA). A série animada De onde vem? pode ser considerada a primeira animação produzida pelo TV Escola. A série possui vinte episódios que são apresentados por Kika (fig. 18), uma criança curiosa, que questiona o funcionamento e a origem de diversos objetos (papel, plástico, vidro) ou fenômenos da natureza (arco-íris, raio, trovão). A última produção do TV Escola é a série Chico na Ilha das Jurubebas (fig. 18), concebida em 2014, destinada à educação infantil e composta por treze episódios. O senhor Manu, ex-marinheiro, construiu um portal que transporta seu neto Chico e o seu papagaio para a Ilha dos Jurubebas.

No caso da SEE-DF, os vídeos exibidos pela programação do canal do TV Escola são gravados e as fitas VHS existentes no acervo estão sendo convertidas em formato digital e, posteriormente são armazenados na videoteca ${ }^{37}$. No mesmo local, encontra-se o Canal $E$, que produz vídeos institucionais e realiza a cobertura dos principais eventos que ocorrem na SEE-DF, nas escolas ou que estejam relacionados à educação. A princípio, não se encontraram dados históricos sobre a data de criação da videoteca. A única informação obtida refere-se à década de sua criação, nos anos de 1970. Atualmente, a videoteca conta com um acervo de 3475 DVDs, sendo considerada uma das maiores do Brasil ${ }^{38}$. O acervo de Ciências Naturais conta com mais de 1500 títulos, sem contar os títulos de temas transversais ${ }^{39}$, e inclui 55 séries de animações.

\footnotetext{
${ }^{35}$ No início da implementação do programa, a escola recebia um "kit tecnológico", que incluía um aparelho de videocassete, uma antena parabólica, um receptor de satélite e uma caixa de dez fitas de vídeo.

${ }^{36} \mathrm{http}: / /$ www.tvescola.mec.gov.br.

${ }^{37}$ A videoteca localiza-se na Gerência de Tecnologia - GTEC - Unidade III da SEE-DF, situada no Setor de Indústria e Abastecimento, Distrito Federal.

${ }^{38}$ Comunicação pessoal.

${ }^{39}$ Ética, Meio Ambiente, Orientação Sexual, Pluralidade Cultural, Saúde, Trabalho e Consumo.
} 

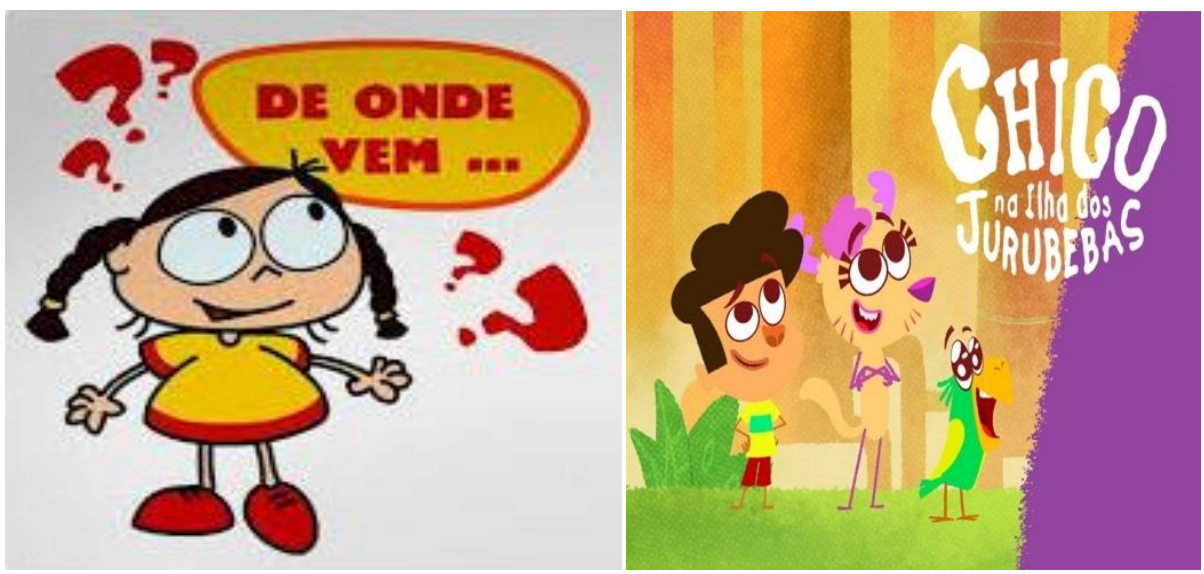

Figura 18. As personagens Kika e Chico, respectivamente. Fonte: http://www.fortalezaculturalinfantil.blogspot.com (Kika) e http://www.pacto.mec.gov.br (Chico). Acesso em: 20 dez. 2014.

Além dos vídeos ou das séries de animações da TV Escola, outras propostas do Ministério da Educação, como o sítio eletrônico do Portal do Professor ${ }^{40}$ na seção Conteúdos Multimídia, oferecem três tipos de animações: o vídeo, a animação/simulação e o software educacional. O Banco Internacional de Objetos Educacionais, também vinculado ao Ministério, é um repositório de acesso público que atende desde a educação infantil até o ensino superior e disponibiliza objetos educacionais na categoria recurso animação/simulação.

A partir das referidas animações, utiliza-se a justificativa explicitada por Poncet, na qual apresenta os motivos pelos quais o desenho animado não poderia ser desprezado:

O desenho animado abriu um caminho em todos os domínios do ensino e não é necessário fazer o seu elogio. Em toda a parte tem lugar. A matéria artística de que é constituído faz dele um elemento de cultura estética, de beleza e de pedagogia que não pode ser desprezado (PONCET, s.d., p. 38).

O desenho animado é considerado uma manifestação artística e, como tal, Poncet (s.d., p. 78) sugere que os desenhos animados sejam incluídos nos programas escolares (currículos), ao afirmar que "importa que os programas escolares apresentem todos os livros necessários para ensinar à criança o que é o desenho animado", para que as crianças aprendam a partir dele e que este possa contribuir para conhecer a natureza por exemplo, o desabrochar de uma flor - conhecer a arte da animação (técnicas utilizadas para a produção do desenho animado), explorar o universo musical das trilhas sonoras dos desenhos animados e promover discussões sobre os temas. Destaca-se no

\footnotetext{
${ }^{40} \mathrm{http}: / /$ www.portaldoprofessor.mec.gov.br.
} 
próximo subitem o desenho animado, entre os diferentes tipos de animações, como recurso pedagógico e as possibilidades de uso em contextos e situações escolares distintas.

\subsection{Contextos de produção ou de indicação de desenhos animados para o uso nas escolas}

\subsubsection{Projeto Anima Escola}

O projeto Anima Escola é uma proposta de utilização de animações com fins educativos. O projeto é resultante do Estúdio Aberto, a parte interativa do ANIMA MUNDI, na qual o público participa da montagem, da produção e da filmagem de animações. O Anima Escola oferece cursos e oficinas a alunos e professores, de redes particulares ou públicas de diferentes lugares do Brasil, para que possam criar seus próprios filmes de animação. O objetivo do projeto é incorporar a linguagem da animação no cotidiano da escola. Desde 2002, a maior parceria do projeto é a Secretaria Municipal de Educação do Rio de Janeiro, que conta com a participação das escolas da rede (MILLIET; MAGALHÃES, 2011).

A introdução da linguagem da animação inclui atividades que vão desde o curso de introdução à produção de animações. O programa MUAN $^{41}$ é a ferramenta utilizada para a captura e a edição das animações. Os professores das escolas participantes recebem um DVD com os filmes produzidos durante o projeto que, posteriormente, integra a videoteca da escola (MILLIET; MAGALHÃES, 2011).

\subsubsection{Curta na Escola ${ }^{42}$}

O projeto Curta na Escola surgiu em 2006 e disponibiliza o acervo de filmes por meio do sítio eletrônico do projeto. Atualmente, o acervo possui 397 curtas-metragens e o gênero animação possui 82 curtas-metragens. A proposta do projeto Curta na Escola surgiu a partir do Projeto Porta Curtas Petrobras, criado em 2002, e que incentiva o uso de filmes de curta-metragem produzidos no Brasil como recurso pedagógico.

\footnotetext{
${ }^{41}$ O Manipulador Universal de Animações - MUAN, ou vaga-lume (em tupi guarani), é um software para animação gratuito, compatível com o sistema operacional LINUX, desenvolvido pelo Instituto de Matemática Pura e Aplicada - IMPA, concebido pelo ANIMAMUNDI e desenvolvido com fins educativos para serem utilizados nos cursos e oficinas promovidos pelo ANIMAMUNDI e pelo projeto Anima Escola.

${ }^{42}$ Para a elaboração do presente texto, as informações foram compiladas do sítio eletrônico do referido projeto, disponível em: <http://www.curtanaescola.org.br $>$. Acesso em: 21 nov. 2012.
} 
A concepção pedagógica do projeto é pautada em três pressupostos: os conteúdos dos curtas-metragens abordam temas sobre a cultura e a sociedade brasileira; os filmes são de curta duração (aproximadamente quinze minutos); e a possibilidade de uso em sala de aula com diferentes objetivos e finalidades (introdução de um tema, desenvolvimento de projetos, promoção de debates).

Além da disponibilização dos filmes, o portal eletrônico sugere os planos de aulas, a indicação dos componentes curriculares, os temas transversais e as etapas e modalidades da Educação Básica e do Ensino Superior. A página do projeto permite aos professores cadastrados compartilharem os planos de aulas, comentarem sobre os filmes, discutirem nos fóruns e enviarem os relatos das experiências com o uso dos filmes de curta-metragem em sala de aula. $\mathrm{O}$ banco de relatos de experiências pode ser consultado no próprio sítio e os melhores relatos cadastrados podem ser premiados pelo projeto.

\subsubsection{Programa Cine-educação ${ }^{43}$}

O programa Cine-educação nasceu de um programa-piloto concebido pela Cinemateca Brasileira com o intuito de introduzir o cinema na escola para auxiliar os professores na "formação de cidadãos mais ativos" na sociedade. Além disso, o programa busca integrar os alunos na linguagem cinematográfica, despertando o senso crítico, a reflexão e a opinião sobre o conteúdo dos filmes. O projeto tem parceria com municípios de São Paulo e, em 2011, propôs uma iniciativa pioneira no Distrito Federal.

O material pedagógico ${ }^{44}$ do Programa Cine-educação é produzido pela equipe da Cinemateca e por especialistas em educação, cinema e linguagem audiovisual da Universidade de Brasília - UnB e da Universidade de São Paulo - USP. Os filmes selecionados são produções brasileiras de curta ou longa-metragem. O material pedagógico apresenta, em cada edição, um mapa de atividades com a indicação de filmes selecionados, os temas, as etapas e modalidades da Educação Básica (Ensino Fundamental - Anos Finais, Ensino Médio e EJA) e os componentes curriculares que podem ser trabalhados.

O volume II do material pedagógico, na sessão de curta-metragem, apresenta quatro animações brasileiras: Macaco feio... Macaco bonito... (Brasil, 1929); A moça que dançou depois de morta (Brasil, 2003); Pax (Brasil, 2005); e A Ilha (Brasil, 2008).

\footnotetext{
${ }^{43}$ Para a elaboração do presente texto, as informações foram compiladas do sítio eletrônico do referido projeto, disponível em:〈http://www.cineedu.com.br $>$. Acesso em: 15 out. 2011.

${ }^{44}$ Atualmente, existem quatro volumes publicados.
} 
O objetivo do uso das animações neste contexto era possibilitar que o aluno tivesse contato com as diferentes técnicas de animação e realizar o exercício de reflexão sobre a identidade, as crenças e os valores da cultura brasileira.

\subsubsection{Projeto Tela Brasil ${ }^{45}$}

O projeto Cine Mambembe foi criado em 1996, pelos cineastas Laís Bondasky e Luis Bolognesi. O projeto exibia filmes brasileiros em praças e escolas públicas do estado de São Paulo com o objetivo de possibilitar o acesso ao cinema aonde ele não existia. Posteriormente, o projeto contou com novas equipes e equipamentos (projetores) e obteve o apoio do Ministério da Cultura.

A exibição de filmes ultrapassou as fronteiras de São Paulo, visitando outros estados brasileiros. Em 2004, o projeto Cine Mambembe se transformou em Cine Tela Brasil e, por meio de patrocínio direto, viabilizou a aquisição de uma sala de cinema móvel. Desde 2007, o projeto conta com a oficina itinerante de vídeo Tela Brasil, formada por uma equipe de cineastas-educadores com o objetivo de compreender a linguagem audiovisual e as etapas de produção de um filme para as comunidades visitadas.

Em 2008, com novos patrocínios, foi criado o Portal Tela Brasil, que integra o Projeto Cine Tela Brasil e os projetos paralelos como as Oficinas itinerantes, Educativo Tela Brasil, Energia em Cena, Cinema no ar e Projeta Brasil. O portal disponibiliza oficinas virtuais e materiais de apoio para os professores.

$\mathrm{Na}$ seção Em sala de aula, encontramos os filmes brasileiros sugeridos de acordo com a etapa de ensino, assim como os materiais de apoio que apresentam sugestões de atividades e de links sobre os temas, as informações técnicas e as curiosidades. Os filmes de animação sugeridos são: Rio (EUA, 2011) A Era do Gelo 3 (EUA, 2009), Garoto Cósmico (Brasil, 2007), O Grilo Feliz e os Insetos Gigantes (Brasil, 2009) e Turma da Mônica: uma aventura no tempo (Brasil, 2007).

Em 2013, o projeto Cine Escola - Tela Brasil visitou o Distrito Federal. Cerca de cinquenta alunos de uma escola de Taguatinga pertencente à SEE-DF participaram da oficina itinerante sobre o cinema oferecida pelo projeto, com aulas práticas e teóricas, e da produção de curtas-metragens, utilizando técnicas de animação. Após cinco dias de evento, os alunos exibiram os desenhos animados produzidos, que tinham a duração de

\footnotetext{
${ }^{45}$ Para a elaboração do presente texto, as informações foram compiladas do sítio eletrônico do referido projeto, disponível em:<http://www.telabr.com.br>. Acesso em: 21 nov. 2012.
} 
dois a cinco minutos ${ }^{46}$. O projeto supracitado - assim como o Anima Escola, o Curta na Escola e o Cine-educação - é exemplo de como os desenhos animados ou os filmes de animação podem ser utilizados em sala de aula, seja na produção por alunos ou por professores, seja como recurso pedagógico.

Para isso, é necessário um planejamento com a finalidade de avaliar a abordagem do tema apresentado na narrativa e a adequação para a faixa etária para a qual será exibida o desenho. Napolitano (2005) assinala que o uso de filmes, incluindo os desenhos animados, no ensino formal, deve ser analisado dentro das seguintes questões: as possibilidades técnicas e organizativas-e.g., o filme de animação tem duração de oitenta minutos e a aula conta com cinquenta minutos; a articulação com o conteúdo do currículo, as habilidades e os conceitos; e a abordagem conforme a faixa etária e a etapa de aprendizagem.

Para a proposta do presente estudo destaca-se a articulação com os conceitos:

[...] os conceitos presentes nos argumentos, nos roteiros e nas situações direta ou indiretamente relacionadas com os filmes selecionados pelo professor são inumeráveis, podendo ser retirados ou inferidos diretamente do conteúdo fílmico em questão ou sugerido pelos problemas e debates suscitados pelas atividades com cinema em sala de aula e projetos escolares (NAPOLITANO, 2005, p. 19).

Nesse caso, cabe ao professor escolher entre as inúmeras possibilidades de uso de conceitos abordados na narrativa ou no conteúdo fílmico, como denomina o autor. Convém ressaltar que os desenhos comerciais, aqueles transmitidos por canais televisivos abertos ou fechados, não têm o compromisso de apresentar os conceitos científicos porque não foram produzidos com esse objetivo.

Até mesmo os desenhos animados elaborados com a finalidade de divulgação científica podem apresentar definições incoerentes com os conceitos científicos vigentes porque se constituem em uma obra fictícia. Igarapé Mágico (Brasil, 2013) (fig.19) aborda sobre a fauna e a flora da Amazônia e Pequenos Cientistas (Brasil, 2009) (fig.19), programa apresentado por dois dinossauros, Diná e Rex, mascotes da revista de divulgação científica Ciência Hoje das Crianças - CHC, ganhou uma versão animada para a televisão, com o objetivo de desvendar o mundo misterioso da Ciência. Estes são exemplos de desenhos animados de divulgação científica transmitidos por canais televisivos brasileiros de caráter educativo, como a TV Brasil e a TV Rá Tim Bum, respectivamente.

46 Disponível em: $<$ http://www.df.gov.br/conteudo-agencia-brasilia/item/6327-filmes-produzidos-poralunos-de-taguatinga-ser\%C3\%A3o-exibidos-nesta-sexta.html>. Acesso em: 10 ago. 2015. 


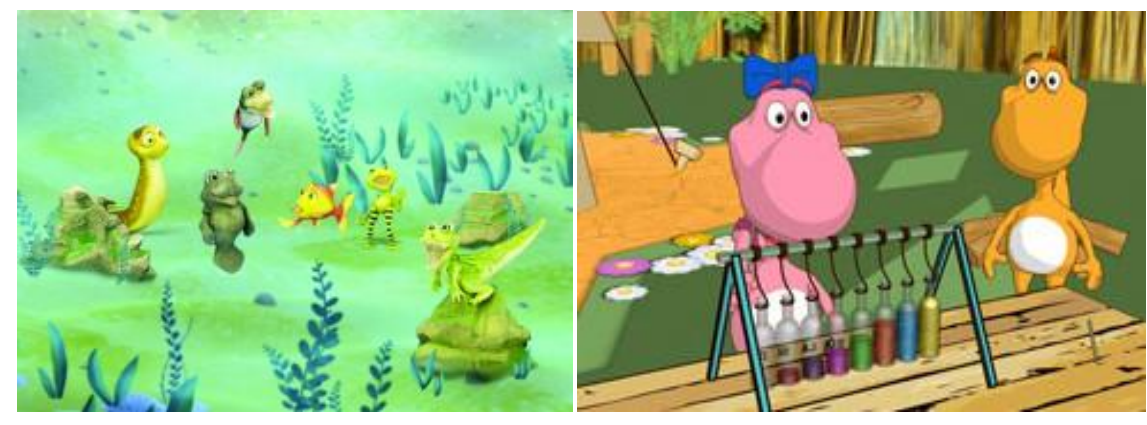

Figura 19. Igarapé Mágico e Pequenos Cientistas (Diná e Rex). Fonte: http://wwww.tvbrasil.ebc.com.br/igarapemagicoe http://www.tvratimbum.cmais.com.br/pequenoscientistas.

Portanto, as características desse tipo de arte como as personagens, o emprego de diferentes técnicas de criação, a elaboração de narrativas envolventes, as imagens em movimento com cenários criativos, a trilha sonora, os sentidos e significados despertados podem contribuir para o ensino aprendizagem de conceitos. $\mathrm{O}$ resgate histórico da relação entre os desenhos animados e a educação permitiu conhecer os primeiros desenhos animados do Brasil que tinham fins didáticos, os contextos em que foram produzidos, e, ainda, os projetos que indicam ou produzem desenhos para o uso nas escolas. Além disso, o histórico possibilitou também identificar as técnicas de produção dos desenhos, assim como a sua evolução, desde a animação tradicional até a animação digital.

Nessa perspectiva, a disponibilidade e a facilidade de acesso aos desenhos (televisão, celular e computador), tanto por alunos quanto por professores, a adequação do processo educacional, as novas tecnologias, a reflexão do conteúdo das mensagens apresentadas nas narrativas e o desenvolvimento da imaginação constituem-se em justificativas para o uso do desenho animado como recurso pedagógico. A partir disso, é possível realizar um levantamento das pesquisas que abordam o uso do desenho animado em sala de aula. 


\title{
CAPÍTULO 2
}

\section{PESQUISAS SOBRE DESENHO ANIMADO, ENSINO DE CIÊNCIAS E EDUCAÇÃO}

\begin{abstract}
O desenho animado em novas mídias como $\mathrm{CD}-\mathrm{ROM}$, videogame, internet $\mathrm{e}$, recentemente, DVD, trata das mesmas fantasias de histórias e fábulas e faz parte de uma estrutura de entretenimento de grande acesso, tanto diretamente ao público infantojuvenil quanto como estratégia de ensino nos ambientes educacionais (XAVIER, 2008, p. 16-17).
\end{abstract}

A revisão bibliográfica teve o intuito de identificar os estudos já realizados referentes à temática, desenho animado e educação para verificar quais foram os desenhos animados utilizados e o tipo de abordagem. As estratégias de busca utilizadas foram as palavras-chaves desenho animado e educação, em língua vernácula, e, para a produção estrangeira, utilizamos as seguintes palavras-chaves, no idioma espanhol e no idioma inglês: dibujos animados e cartoon, além de algumas variações ${ }^{47}$, para identificar tais publicações científicas que tinham como objeto de pesquisa "o uso do desenho animado" em contexto de ensino. E, ainda, a consulta nas bases de dados eletrônicos da Coordenação de Aperfeiçoamento de Pessoal do Ensino Superior CAPES, Education Resources Information Center - ERIC e Instituto Brasileiro de Informação em Ciência e Tecnologia - IBICT no período compreendido entre 1993 e 2013. A busca limitou-se a artigos, dissertações de mestrado e teses de doutorado.

Para a realização desta revisão bibliográfica, os artigos de dezenove revistas ${ }^{48}$, entre nacionais e internacionais da área de ensino de ciências e educação, foram selecionados com base nos seguintes critérios: (i) por serem da área de Educação; (ii) por serem da área de Ensino de Ciências e Tecnologia, em função da área de concentração e da linha de pesquisa do estudo em questão; (iii) por estarem qualificadas como periódicos com conteúdos científicos; e (iv) pelo tempo de existência das revistas, visto que a busca dos artigos compreende o período entre 1993 e 2013. Além desses

\footnotetext{
${ }^{47}$ No idioma espanhol, películas de animación, e no idioma inglês, animated cartoon, animated film $\mathrm{e}$ animated movie.

${ }^{48}$ Nove revistas nacionais e dez estrangeiras (seis de língua espanhola e cinco de língua inglesa).
} 
critérios, por serem revistas de fácil veiculação e disponíveis na internet. As revistas ${ }^{49}$ selecionadas foram:

a) Revistas Nacionais: Ciência \& Educação (2002-2013), Ciência \& Cultura (2002-2013), Educação \& Sociedade (1978-2013), Educação \& Tecnologia (1997-2013), ENSAIO - Pesquisa em Educação em Ciências (1999-2013), Investigações no Ensino de Ciências (1996-2013), Revista Brasileira de Educação (1995-2013), Revista Brasileira de Ensino de Ciência e Tecnologia (2008-2013), Revista Brasileira de Pesquisa em Educação em Ciências ABRAPEC (2001-2013);

b) Revistas Internacionais de idioma espanhol: Enseñanza de las Ciências (19832013), Revista Electrónica Enseñanza de Las Ciências (2003-2013), Revista Electrónica de Investigación en Educación en Ciencias (2006-2013), Revista Eureka sobre Enseñanza y Divulgación de las Ciencias (2004-2013), Revista Latinoamericana de Tecnologia Educativa (2002-2013).

c) Revistas Internacionais de idioma inglês: Cultural Studies of Science Education (2006-2013), International Journal of Science Education (1979 ${ }^{50}$ 2013), Journal of Science Education and Technology (1992-2013), Science Education (1916-2012), Science \& Education (1992-2013).

A busca das produções nacionais de teses de doutorado e dissertações de mestrado foi realizada no Banco de Teses e Dissertações da Biblioteca Digital de Teses e Dissertações - BDTD (2003-2013) ${ }^{51}$, coordenada pelo IBICT, vinculado ao Ministério da Ciência, Tecnologia e Inovação, e, também, no banco da CAPES (2006-2013) ${ }^{52}$, com as palavras-chaves desenho animado e educação. Foram identificados três artigos em periódicos nacionais, cinco artigos em periódicos internacionais, nove dissertações e, finalmente, seis teses. Ao total, foram obtidos 23 trabalhos.

Posto isso, buscou-se destacar nessas produções científicas os desenhos animados utilizados, os objetivos e os principais resultados das pesquisas realizadas no contexto educativo. Após leituras sucessivas dos trabalhos acadêmicos selecionados,

\footnotetext{
${ }^{49}$ Optou-se por colocar o ano entre parênteses em função da diferença do primeiro ano de publicação de cada revista pesquisada.

${ }^{50}$ Desde a primeira publicação, em 1979, até 1986, a revista era intitulada como European Journal of Science Education.

${ }^{51}$ Período em que foi realizada a busca, o primeiro ano é consoante à data de criação do banco de teses e dissertações da referida instituição citada.

${ }^{52}$ Idem à nota de rodapé 50.
} 
estes foram agrupados de acordo com o objetivo de cada estudo, sendo organizados da seguinte forma: recursos pedagógicos, concepções de Ciência, representação de gênero e de ciência, e, por último, formação de valores e representação de violência.

\subsection{Recursos pedagógicos}

Os recursos pedagógicos referem-se aos estudos que abordam o uso do desenho animado em sala de aula. Nessa categoria, foram encontrados um artigo nacional (RIBEIRO et al, 2012), quatro artigos internacionais (PERALES-PALACIOS; VILCHEZ-GONZÁLEZ， 2005; VILCHEZ-GONZÁLEZ; PERALES-PALACIOS， 2005; PILIOURAS et al, 2011; HOBAN; NIELSEN, 2013) e três dissertações (XAVIER, 2008; GARCIA, 2009; SILVA, 2011).

Os pesquisadores Perales-Palacios e Víchelz-González (2005) buscaram descrever os procedimentos e os resultados da inclusão do desenho animado no currículo de Física do ensino médio, com o objetivo de evidenciar a relação entre a educação escolar e a televisão. Segundo os autores, o uso dos desenhos animados possibilita desenvolver o senso crítico dos alunos diante das mensagens recebidas por um dos principais meios de massa (a televisão) e desenvolver, ao mesmo tempo, a alfabetização científica $^{53}$ e visual $^{54}$. Os desenhos utilizados foram Os Simpsons (EUA, 1989) e Pokémon (Japão, 1997). Para esses autores, o uso de desenhos animados como recurso didático desperta o interesse do aluno pelo tema estudado. A partir da visualização dos fenômenos físicos apresentados nos episódios selecionados, os alunos desenvolveram a capacidade de argumentação e a reflexão nos debates realizados. Os desenhos constituíram-se em recursos para identificar as ideias prévias dos alunos, assim como autoavaliar a sua aprendizagem e, principalmente, permitir que os alunos avaliassem criticamente os conteúdos das mensagens televisivas, corroborando o conteúdo ou refutando as mensagens ou as situações apresentadas nos desenhos animados com os conteúdos aprendidos em sala de aula.

Em outro estudo, os mesmos autores (2005) propuseram o uso dos desenhos animados Os Simpsons (EUA, 1989) e Pokémon (Japão, 1997) como estratégia didática para ensinar Física com o intuito de promover discussões em que os alunos refletissem

\footnotetext{
${ }^{53}$ Para os autores, a alfabetização científica "tem como objetivo fornecer aos cidadãos as ferramentas cognitivas para a interpretação do mundo que nos rodeia e agir de forma crítica nele" (PERALESPALACIOUS; VÍLCHEZ-GONZÁLEZ, 2005, p. 1649).

${ }^{54}$ A autora portuguesa Isabel Calado ressalta que "o processo de alfabetização visual, [...] corresponde à tomada de posse de uma arma estratégica. Quer isto dizer que as imagens usadas na sala de aula não devem sê-lo gratuitamente, mas que devemos conhecer os seus componentes sintácticos e semânticos para adequá-los aos objectivos que perseguimos" (CALADO, 1994, p. 51).
} 
sobre a veracidade das mensagens e dos fenômenos apresentados nas narrativas dos desenhos. Os principais objetivos foram melhorar o desempenho dos estudantes nas disciplinas de Física e Química, promover a alfabetização científica e visual dos adolescentes e relacionar os diferentes tipos de conhecimento (científico, cotidiano e escolar $)^{55}$. Os autores concluíram que o uso dos desenhos animados constitui um elemento motivador para a participação dos estudantes em sala de aula e o desenvolvimento do senso crítico das mensagens televisivas que possibilitam uma conexão entre os diferentes tipos de conhecimentos.

Com objetivos diferentes relacionados ao uso do desenho animado, Xavier (2008), em sua dissertação de mestrado, buscou avaliar o potencial pedagógico do DVD Desenho Animado Ambiental- DAA (Brasil, 2005). O DAA é composto por sete ${ }^{56}$ animações com temáticas ambientais produzido pelo Instituto CARANGUEJO de Educação Ambiental de Joinville, Santa Catarina. A principal personagem do desenho é o Menino Caranguejo, que apresenta conceitos da área ambiental e desenvolve princípios éticos e valores morais para a sensibilização da questão ambiental. A partir dos relatos dos professores participantes da pesquisa, constatou-se a eficácia do conteúdo do DAA, que possibilitou desenvolver conceitos, hábitos e atitudes tanto pelos professores quanto pelos alunos. As atividades realizadas com o uso do desenho animado como discussões, debates e reflexões também possibilitaram a confrontação com a realidade por meio de situações reais dentro da sua comunidade, como visitas de campo e organização de passeatas.

Em outro contexto de uso do desenho animado, Garcia (2009), em sua dissertação de mestrado, analisou a produção de sentidos em uma aula de Ciências Naturais durante a exibição de uma narrativa de animação que envolvia o conceito de adaptação biológica. O curta-metragem de animação Evolution (Canadá, 1971), de Michael Mills, foi utilizado como recurso pedagógico para abordar o tema evolução. A análise incluía a observação da aula e o registro escrito dos enunciados dos agentes envolvidos (professor e estudantes) na interação discursiva. Os sentidos produzidos na interação discursiva sobre o conceito, adaptação biológica, mostraram a evolução como

\footnotetext{
${ }^{55}$ Segundo García (1998, p. 77), "o conhecimento científico diferiria do cotidiano nos fins que se perseguem, na organização dos conceitos, nos processos utilizados e no contexto de construção" e o conhecimento escolar "é determinado pela integração das contribuições de outros marcos referenciais, além do conhecimento científico, centrando a incompatibilidade não entre o científico e o cotidiano, mas entre o simples e o complexo" (GARCÍA, 1994 apud GARCÍA, 1998).

${ }^{56}$ Cada um dos desenhos animados aborda um tema gerador: poluição urbana, desmatamento, caça ilegal, água, povos nativos, urbanismo e consumismo.
} 
progresso e a adaptação biológica como uma necessidade dos seres vivos, não diferindo de outros estudos já realizados sobre o tema.

Em um trabalho sobre a produção de desenhos animados, Piliouras et al (2011) utilizaram como recurso pedagógico a produção de desenhos pelos alunos sobre a história da Astronomia. O objetivo foi o de melhorar a compreensão dos conceitos e dos experimentos, vinculando o desenvolvimento do pensamento individual com $\mathrm{o}$ desenvolvimento das ideias científicas, para facilitar a compreensão da natureza da ciência por meio da história da Astronomia. Os alunos, motivados a criar o filme de animação, processaram a informação sobre a história da Ciência, desenvolveram suas próprias narrativas e produziram uma variedade de meios expressivos na reelaboração do conteúdo em questão.

Silva (2011), em sua dissertação de mestrado, avaliou o potencial pedagógico dos desenhos animados com o objetivo de verificar em que medida o anime Astro Boy ${ }^{57}$ (Japão, 2005) poderia auxiliar na aprendizagem de conceitos científicos, especificamente os conceitos relacionados à nutrição vegetal. A prova bimestral foi utilizada como instrumento avaliativo da sequência de ensino e os resultados indicaram que houve avanços na aprendizagem, ainda que os alunos não tenham apreendido todos os conceitos envolvidos para a compreensão da fotossíntese. Além desses resultados, a pesquisa também evidenciou que os alunos apresentam dificuldades na compreensão do conceito de energia.

Em pesquisa sobre a produção de desenho animado como recurso pedagógico, Ribeiro et al (2012) investigaram a construção de um organizador prévio ${ }^{58}$ no formato de um curta de animação digital, assim como os critérios didáticos e técnicos envolvidos nessa tarefa. A construção do curta de animação utilizou software livre ${ }^{59}$ para auxiliar a aprendizagem de um conceito físico de força. A partir dos resultados, os autores concluíram que os alunos assimilaram o conteúdo sobre o tema Momento de uma força, reconheceram que a aprendizagem foi efetiva com a utilização do curta de

\footnotetext{
${ }^{57}$ Animes são desenhos animados japoneses. No estudo foi utilizado o episódio Deep City (Cidade subterrânea).

${ }^{58}$ De acordo com a teoria da aprendizagem significativa de David Ausubel, os organizadores são materiais introdutórios apresentados "num grau mais elevado de generalidade, inclusividade e abstração do que a própria tarefa de aprendizagem, e explicitamente relacionado tanto com as ideias relevantes existentes na estrutura cognitiva quanto à própria tarefa de aprendizagem", e, ainda, os organizadores são destinados a "promover a aprendizagem subordinativa ao oferecer um arcabouço ideacional ou um esteio para a tarefa de aprendizagem e/ou ao aumentar a discriminabilidade das novas ideias a serem aprendidas em relação com as ideias já existentes na estrutura cognitiva; isto é, preencher o hiato entre aquilo que o aprendiz já sabe e o que ele precisa saber para aprender o material de aprendizagem mais rapidamente" (AUSUBEL; NOVAK; HANESIAN, 1980, p. 525).

${ }^{59} \mathrm{~A}$ produção foi realizada com o software Blender 2.48 (HESS, 2007) e o conjunto completo de criação 3D de licença pública GPL (FITZGERALD, 2006 apud RIBEIRO et al, 2013).
} 
animação. As características do curta de animação, como o tempo de duração (dois minutos e quarenta e sete segundos), o roteiro focado, a criação e a disponibilização em formato digital foram suficientes para o uso como organizador prévio.

Em outro contexto de produção, Hoban e Nielsen (2013) examinaram um estudo de caso em que a produção de desenhos animados foi realizada por professores de anos iniciais para ensinar conceitos da área de Ciências. O objetivo era planejar e produzir uma narração utilizando a técnica de stop motion para explicar um conceito científico sobre o ciclo de vida de uma joaninha, utilizando um tipo de animação chamado slow motion (câmera-lenta). A partir do estudo de caso, os autores concluíram que ao longo da produção do desenho animado, os professores tiveram a oportunidade de revisitar os conteúdos, constituindo em um novo caminho para a mudança conceitual em que confrontaram e revisaram as suas concepções prévias. Além disso, os professores tiveram a oportunidade de utilizar diversos recursos tecnológicos para criar a animação, como o computador, as máquinas fotográficas digitais e os softwares livres.

\subsection{Concepções de Ciências}

As concepções de Ciências referem-se aos estudos que abordam a compreensão de ideias, de visões e de imagens de ciência e cientista veiculadas em desenhos animados. Nesse agrupamento, foram identificados dois artigos nacionais (MESQUITA; SOARES, 2008; TOMAZI et al, 2009) e duas dissertações (BORTOLETTO, 2008; MONTEIRO, 2011).

Com o propósito de analisar as ideias veiculadas, Bortoletto (2008), em sua dissertação de mestrado, investiga o processo de recepção ${ }^{60}$ do desenho animado Tio Patinhas (EUA, 1947) em crianças (8-9 anos de idade) em duas escolas de contextos diferentes da cidade de Tietê, São Paulo. Nesta pesquisa, buscou-se compreender como a narrativa e os contextos influenciam na recepção e na interpretação das ideias e das mensagens veiculadas no desenho animado e como são interpretadas pelas crianças. A partir da exibição dos desenhos animados e da análise das falas das crianças, a autora constatou que as crianças atribuem significados às situações vivenciadas e emaranhamse com outros discursos sociais nos contextos nos quais elas estão envolvidas. Nas falas das crianças, a autora observou que ocorre a circulação de ideias e a construção de

\footnotetext{
${ }^{60}$ Nos estudos sobre os processos de recepção, a comunicação ocorre como trânsito de sentidos. Neste sentido, a autora utiliza a definição de processo de recepção proposta por Jesús Martín Barbero como sendo um "processo de interação; na expressão dos italianos, é um processo de negociação de sentido" (MARTÍN-BARBERO, 1995, p. 57apud BORTOLETTO, 2008, p. 7).
} 
valores, sendo as novas ideias construídas mediante reelaborações e ressignificações simbólicas por meio da imaginação.

No artigo intitulado Visões de Ciência em desenhos animados: uma alternativa para o debate sobre a construção do conhecimento científico em sala de aula, Mesquita e Soares (2008) buscaram identificar quais são as visões de Ciência veiculadas nos desenhos animados e relacioná-las com algumas visões de epistemólogos da Ciência, como meio de detectar formas de como a Ciência é apresentada para a sociedade e como ela é pensada pelos autores desses desenhos. Os desenhos animados utilizados para a análise foram O laboratório de Dexter (EUA, 1996) e Jimmy Neutron (EUA, 2002). Os autores concluíram que os personagens Dexter e Jimmy Neutron possuem características comuns, como: a caracterização física de um cientista (Dexter utiliza jaleco e Jimmy utiliza uma camisa vermelha com o símbolo do átomo de Rutherford) (fig.20); o fato de trabalharem sozinhos e a atividade científica ser considerada restrita ao gênero masculino.

Os "meninos cientistas" transmitem a imagem do cientista veiculada pela mídia como sendo a de pessoas com a inteligência acima da média, dedicadas às suas experiências e sem vida social ou afetiva.
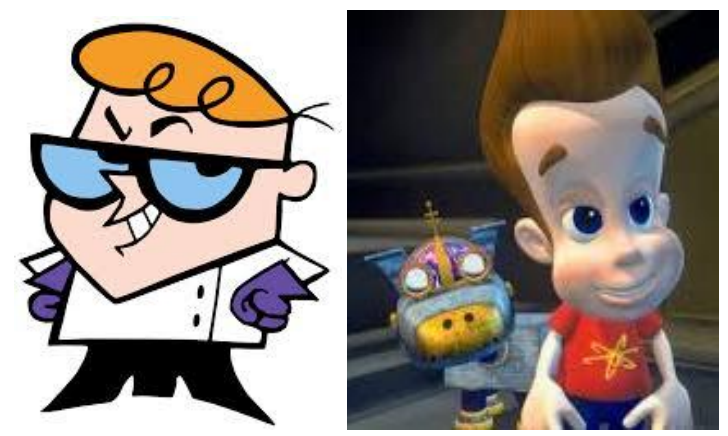

Figura 20. Personagens de desenhos animados Dexter e Jimmy Neutron, respectivamente. Fonte: http://www.minhateca.com.br e http://www.pixsshark.com. Acesso em: 2 abr. 2015.

As visões de ciência identificadas foram a popperiana, a lakatosiana, a kuhniana e a positivista, sendo esta última a mais predominante. Para os autores, o professor pode ser um sujeito atuante e questionar as múltiplas visões de ciência que são veiculadas nos meios de comunicação e assim conduzir os alunos à reflexão acerca do desenvolvimento do pensamento científico e o papel da ciência nas nossas vidas (MESQUITA; SOARES, 2008).

Em outro artigo, Tomazi et al (2009) também caracterizaram as imagens tanto de ciência como de cientista veiculadas em filmes de animação infantil com o objetivo 
de contribuir com a discussão de alternativas didáticas para a educação científica de crianças. Ao total, encontraram nove produções cinematográficas infantis que continham as palavras ${ }^{61}$ relacionadas à Ciência e à atividade científica na sua sinopse: $A$ Família do Futuro (EUA, 2007); Stitch! O Filme (EUA, 2003); Jimmy Neutron: Boy Genius (EUA, 2002); Pink e Cérebro (EUA, 1995); As Meninas Superpoderosas Conhecendo os Beat-Alls (EUA, 2001); Steamboy (Japão, 2004); Mamãe, virei um peixe (Alemanha, 2000); Cine Gibi - O Filme (Brasil, 2004) e Jonny Quest - $1^{a}$ Temporada (EUA, 1964).

Dos nove filmes analisados, sete apresentaram concepções de ciência em que não há evidência de aspectos históricos e coletivos da construção do conhecimento, ou seja, a concepção de Ciência apresentada é a-histórica, neutra, individualista, utilizada para o benefício próprio ou como "salvadora da humanidade" (em que desconsidera os interesses sociais, políticos e econômicos presentes no seu desenvolvimento), mostrando que os cientistas não precisam de pressupostos e/ou referências a outros estudos na investigação de um objeto.

Com relação à concepção de cientista, a maioria era do sexo masculino, adulto, com estilo casual e, geralmente, trajado de jaleco mesmo quando não está trabalhando no laboratório ou na pesquisa científica. A maioria dos personagens cientistas (sete) possuía etnia caucasiana $^{62}$, algum tipo de relacionamento social e, em seis produções, a atividade científica exercida pelos cientistas era solitária. Os dados obtidos também revelaram que a atividade do cientista é exercida em laboratório e utiliza diversos equipamentos (ferramentas de registro, substâncias químicas e vidrarias) e a área de atuação predominante é a tecnológica.

Em sua dissertação de mestrado, Monteiro (2011) avaliou a percepção e a maneira como repercutem nos adolescentes as concepções de Ciência veiculadas em três episódios do desenho animado Jimmy Neutron (EUA, 2002). A pesquisa foi realizada com trinta e um alunos do $9^{\circ}$ ano do ensino fundamental de uma escola pública de Maringá, Paraná. A análise dos depoimentos dos alunos revelou uma concepção simplista, sendo as únicas funções da Ciência e dos cientistas a invenção e a descoberta de técnicas. Além disso, a autora concluiu que a Ciência é percebida pelos alunos como incompreensível, impossível, metódica, e a figura do cientista representa

\footnotetext{
${ }^{61}$ Ciência, cientista, laboratório, experimento, pesquisa, pesquisador (es), investigação/lógica científica, invenção e/ou inventores.

${ }^{62}$ Termo utilizado para se referir a pessoas de pele clara.
} 
um ser dotado de uma inteligência nata e uma pessoa isolada do convívio social, corroborando com os dados das pesquisas citadas anteriormente.

\section{3 Formação de valores e representação de violência}

A formação de valores abarca os estudos sobre a análise das narrativas apresentadas nos desenhos animados que podem influenciar quanto à formação de valores e à determinação de comportamentos agressivos em crianças e a representação de violência. Nesta categoria, foram identificadas três dissertações (WENZEL, 2002; MIRANDA, 2009; LEITÃO, 2011) e três teses (ROCHA, 2005; MAREUSE, 2007; SILVA, 2010).

Em sua dissertação de mestrado, Wenzel (2002) buscou analisar os mitos presentes no episódio A família cartucho, da série de desenho animado Os Simpsons (EUA, 1989), e relacionar com a formação das crianças e dos jovens (faixa etária entre onze e quinze anos) quanto aos valores construídos pela sociedade a qual tem a cultura pautada no consumo. Conforme a autora, no desenho Os Simpsons (EUA, 1989), concentram-se os problemas referentes ao comportamento humano que são disfarçados em forma de diversão. A autora destaca que:

[...] as personagens de 'Os Simpsons' são representantes e executores de tendências e mecanismos ideológicos vigentes no mundo do adolescente: sua ação coincide com a forma pela qual o modo de produção capitalista reproduz sua dominação na mente, hábitos e vida dos jovens (WENZEL, 2002, p. 104).

A autora conclui que da identificação emocional e cômica dos adolescentes com as situações apresentadas, vividas pelas personagens, surge a diversão. O problema é que os adolescentes tomam os valores das personagens não apenas no momento em que se entregam ao programa, mas também quando esses valores continuam depois que o programa termina.

Em outro estudo, realizado por Rocha (2005), em sua tese de doutorado, propôs realizar um estudo para compreender as relações entre crianças, televisão e animes. Os animes utilizados para o estudo foram Dragon Ball Z (Japão, 1996) e Pokémon (Japão, 1997). Segundo a autora, embasada nas enunciações de oito crianças participantes da sua pesquisa, as crianças percebem a importância da distinção entre o fictício e o real. Elas assumem que não replicam ações agressivas em virtude de um desenho animado e as crianças mencionam que, se há crianças que se comportam agressivamente repetindo o que assistem nos desenhos, são motivadas pela sua própria personalidade, pela pouca 
idade para o tipo de desenho (referindo-se a crianças de idade inferior a cinco anos). As crianças entrevistadas reconhecem que a ausência de educação e de afetividade familiar pode influir na ocorrência da agressividade e, ainda, elas reconhecem o papel orientador e de intervenção de um adulto no comportamento da criança.

A autora identificou que, apesar de os alunos demonstrarem interesse pelas lutas, golpes e confrontos, como meio de diversão, existem outros aspectos e valores que envolvem "os pequenos apreciadores" dos desenhos animados, como a persistência dos personagens em fazer o bem, a esperança de conquistar o objetivo, as lições de amizade, a admiração aos mestres, o cuidar e o preservar a natureza, além de conhecerem a cultura japonesa. Outro aspecto observado pela autora é que a escola não se envolve, nem tem participado do contexto cultural das crianças e mantém um relativo silêncio quanto ao universo dos desenhos animados. Assim, deixam de perceber o quanto as crianças podem criticar, polemizar, rejeitar, interpretar, argumentar de forma ativa e fundamentada a partir de suas histórias de vida (ROCHA, 2005).

Por sua vez, a proposta de Mareuse (2007) teve como objetivo conhecer a representação ${ }^{63}$ infantil da violência no desenho animado e obter uma concepção de violência que caracterize o universo infantil pautada nas representações que as crianças constroem nas relações sociais e nas relações com a mídia. Para isso, a autora entrevistou trinta crianças (na faixa etária de seis a onze anos) e os seus responsáveis legais. A maioria dos responsáveis entrevistados não acredita na influência direta da TV sobre o comportamento da criança e reconhecem que a TV participa do processo educativo, mas responsabilizam outros espaços como a família e a escola pelo comportamento da criança. Corroborando com o discurso dos pais, as crianças discriminam a violência real da ficcional, elas não reconhecem os desenhos como violentos. Muitas vezes, as crianças reproduzem os personagens e os comportamentos deles nas brincadeiras, porém afirmam, por exemplo, que não matariam na vida real.

A partir das falas das crianças, a autora concluiu que foi possível apreender que elas são capazes de especificar com clareza os gêneros televisivos ou as situações com as quais se sentem vulneráveis e descrevem suas reações frente a elas, agrupadas em três categorias: filmes de terror, situações que remetem a possibilidades reais (que poderiam atingi-las) e a violência real retratada pelos telejornais. A maneira como as crianças se propuseram a falar sobre a violência é reveladora, porque demonstra o quanto elas estão familiarizadas com ela e quais os valores estão sendo construídos à

${ }^{63}$ No sentido de representação social, como proposto pela teoria da representação social, de Serge Moscovici. 
margem delas. A autora ainda destaca que a televisão e a vida estão sendo capazes de colocar as crianças a par da violência, então se faz necessário experimentar outras ações que possibilitem oferecer às crianças outros modelos e outros espaços de ação e diálogo (MAREUSE, 2007).

O tema valores é uma constante nos desenhos animados. Com a preocupação da influência dos desenhos animados na formação da criança, Miranda (2009), em sua dissertação de mestrado, buscou analisar os valores educativos, presentes ou ausentes, nos conteúdos de dois episódios de cada um dos quatro desenhos animados exibidos na programação televisiva: Os Padrinhos Mágicos (EUA, 2001); Bob Esponja, Calça Quadrada (EUA, 1999), As Meninas Superpoderosas (EUA, 1998) e Pingu (Suíça/ Reino Unido, 1986), a fim de relacioná-los aos valores a serem desenvolvidos formalmente no currículo da educação infantil. Os desenhos analisados apresentaram valores considerados educativos tais como a amizade, o companheirismo, a cooperação e o respeito, que podem contribuir para o desenvolvimento da proposta do Referencial Curricular da Educação Infantil conforme os Parâmetros Curriculares Nacionais. Os valores considerados como negativos (orgulho, avareza, egoísmo, maldade) são abordados como contribuição ou reforço dos valores tidos como positivos.

Dentro da mesma proposta da formação de valores, Silva (2010), em sua tese de doutorado, investigou como o desenho animado Bob Esponja, Calça Quadrada (EUA, 1999), considerado um instrumento midiático, produz sentidos e influencia na formação de valores e da subjetividade quando assistido por crianças de três a cinco anos de idade. As crianças conferiram um sentido próprio ao conteúdo do desenho, além daquele proposto pelo autor do desenho animado. O desenho Bob Esponja foi o preferido pelas crianças perante outros que foram apresentados e, também, frequentemente assistido pelas crianças participantes do estudo. As crianças se referiram aos personagens do desenho como sendo adultos, destacando qualidades e sentimentos humanos (engraçado, triste, mentiroso, alegre).

Ainda na análise dos conteúdos das narrativas de desenhos animados e a influência na formação de valores, Leitão (2011), em sua dissertação de mestrado, analisou os desenhos animados televisivos Os Padrinhos Mágicos (EUA, 2001), Rocket Power (Canadá/EUA, 1999) e Ben10 (EUA, 2005), com o objetivo de interpretar o discurso ético e a abordagem de conteúdos de Educação Física. A análise e a avaliação das narrativas dos desenhos animados foram realizadas para detectar os valores presentes nas narrativas. A partir destas avaliações, pretendeu-se contribuir para a possível utilização dos desenhos animados televisivos como recurso pedagógico nas 
aulas de Educação Física. $\mathrm{O}$ autor concluiu que a estrutura narrativa dos desenhos responde a um duplo padrão moral construído a partir de modelos estereotipados, como o bem/mal, o certo/errado e o herói/vilão.

\subsection{Representação de Gênero e de Ciência}

As representações de Gênero e de Ciência referem-se aos estudos que abordam o desenho animado em que são apresentadas representações (no sentido de imagem ou de ideia que concebemos de alguém ou de alguma coisa ou objeto) sobre a ciência, o gênero (masculino e feminino) e o professor. Neste agrupamento, foram identificados um artigo internacional (BROWNLOW; DURHAM, 1997), uma dissertação (MEDEIROS, 2010) e três teses (KINDEL, 2003; SABAT, 2003; SANTOS, 2010).

Brownlow e Durham (1997) investigaram a representação ${ }^{64}$ masculina e feminina da atividade científica com relação ao uso da Ciência e da Tecnologia por personagens de desenhos animados. As autoras examinaram múltiplos episódios de quatro desenhos animados: Battle Tech (EUA, 1995), Homem-Aranha (EUA, 1994), Homem de Ferro (EUA, 1994), e X-Men (EUA, 1992). Nos resultados encontrados, os personagens do sexo masculino predominaram no uso da Ciência e Tecnologia com o objetivo de destruição e demonstraram ser agressivos. Ao contrário, as personagens femininas, quando retratadas, demonstraram ser competentes e qualificadas para tal, e a maioria utilizava a Ciência e a Tecnologia para o bem comum e não para a destruição.

Com outra abordagem sobre a representação de gênero, Kindel (2003) buscou analisar, na sua tese de doutorado, como os filmes de animação produzidos pelos Estúdios Walt Disney e Dream Works, como O Rei Leão (EUA, 1994), Pocahontas (EUA, 1995), Vida de Inseto (EUA, 1998), FormiguinhaZ (EUA, 1998) e Tarzan (EUA, 1999) têm se configurado em uma funcionalidade para ensinar. O seu objetivo de pesquisa foi investigar de que forma os desenhos animados vêm atuando como "pedagogias culturais" e que identidades têm sido privilegiadas em suas representações. A autora explica o significado de pedagogia cultural:

Os Das vêm atuando como uma Pedagogia Cultural, ou seja, como uma eficiente forma de ensinar na e pela mídia. Como já comentei anteriormente, nesses filmes se aprende modos de ser homem e de ser mulher, modos de ser civilizado ou não civilizado e, também, concepções de natureza, entre outras questões (KINDEL, 2003, p. 31).

\footnotetext{
${ }^{64}$ No sentido de imagem.
} 
A criança costuma assistir inúmeras vezes aos mesmos episódios e pode fixar de forma efetiva os sentidos e as informações que podem produzir determinadas identidades de gênero e de cultura. Em sua conclusão, expõe "o que parece claro é que, cada vez mais, educadores têm que ficar atentos a essas produções que raramente são questionadas, devido ao caráter lúdico e 'inocente' que as configura” (KINDEL, 2003, p. 184).

Ainda sobre a representação de gênero, em sua tese de doutorado, Sabat (2003) apresenta fragmentos de discurso sobre o sexo, o gênero e a sexualidade com o objetivo de demonstrar o quanto tais discursos são importantes para o processo de normalização da heterossexualidade. Conforme a autora, essa tese trata da "heterossexualidade como algo não natural e sim como uma condição construída culturalmente" (SABAT, 2003, p. 21). A autora utiliza a definição de heterossexualidade proposta por Jonathan N. Katz, em sua obra A invenção da heterossexualidade:

A heterossexualidade é inventada no discurso como o que está fora dele. É criada em um discurso particular como o que é universal. É construída em um discurso historicamente especifico como o que não se restringe ao tempo. Foi construída bastante recentemente como o que é muito antigo: a heterossexualidade é tradição inventada (KATZ, 2002, p. 186).

Para isso, a autora se propôs a analisar de que formas as identidades de gênero são apresentadas nos filmes de animação infantis produzidos pelos Estúdios Walt Disney como A Pequena Sereia (EUA, 1989), A Bela e a Fera (EUA, 1991), O Rei Leão (EUA, 1994) e Mulan (EUA, 1998), com o objetivo de questionar o que é identificado como normal. As personagens femininas e masculinas são frequentemente representadas de formas semelhantes: mocinha bela, magra e bondosa; e mocinho bonito, forte e corajoso. A título de ilustração, a figura 21, a seguir, apresenta seis princesas da Disney e o ano de criação de cada uma. Destacam-se na imagem as características identificadas por Sabat (2003) em menção de duas delas: a pequena Sereia e a princesa Bela. Para a autora, a frequência com que tais características das personagens qualificadas como padrão caracterizam-se como um discurso hegemônico, que reforça a identidade de um arquétipo de gênero o qual dissimula as diferenças do olhar de um indivíduo sobre o outro. 


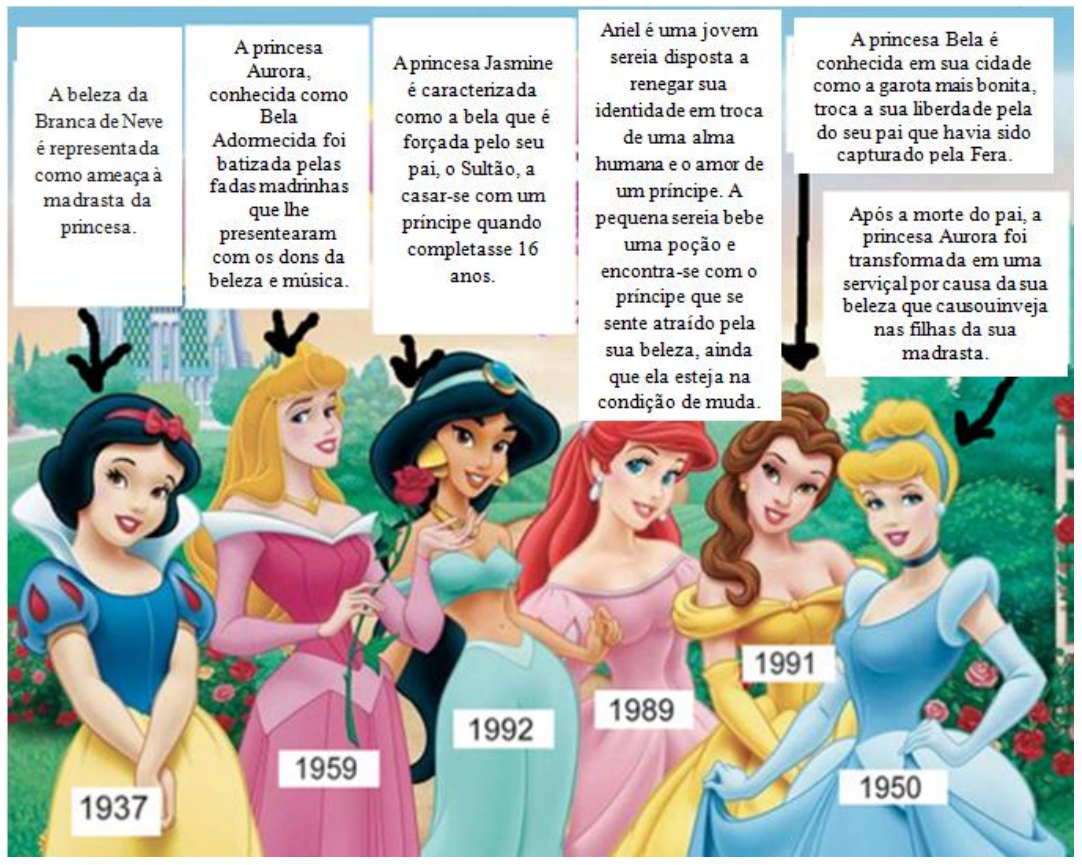

Figura 21. As princesas da Disney. Texto adaptado da ilustração original. Fonte: http://www.mardemarmore.blogspot.com. Acesso em: 12 maio 2015.

Em outro contexto de representação, Santos (2010), em sua tese de doutorado, analisou as representações ${ }^{65}$ de gênero e de professor apresentadas nos desenhos animados Os anjinhos (EUA, 1991) e As Terríveis Aventuras de Billy \& Mandy (EUA, 2001), de episódios exibidos no período entre 1991 e 2010 pelos canais por assinatura Cartoon Network e Nickelodeon. A autora concluiu que o humor utilizado nas narrativas analisadas torna os estereótipos dos personagens mais reconhecíveis do que outros e investem em uma polarização masculina e feminina. Além disso, os significados criados sobre as personagens dos desenhos operam instituindo parâmetros, incluindo uns e excluindo outros, enfatizando uma supremacia nas meninas e naturalizando determinado comportamento; por outro lado, ressaltam as incapacidades (ou inabilidades) do masculino.

Quanto à representação de professor (a), Santos (2010) concluiu que algumas representações confirmam a figura do professor como o sábio e, tomadas emprestadas as palavras da autora, conhecedores da "magia de ensinar". Em contraposição, a autora observou que a figura do professor estava também produzindo outras vertentes, como a representação de professora sem compaixão, ternura, afetividade e com preguiça. $\mathrm{O}$ estereótipo referente a um saber maior e ao exercício do domínio sobre os alunos com autoridade e castigos estava vinculado à figura masculina de professor. A imagem de

\footnotetext{
${ }^{65}$ No sentido de imagem.
} 
professor (a) retratada nos desenhos animados pode estar produzindo novas identidades a serem questionadas, assim como os seus efeitos sociais (SANTOS, 2010).

Várias pesquisas têm sido realizadas com o desenho Bob Esponja, Calça Quadrada com diferentes enfoques. Medeiros (2010), em sua dissertação de mestrado, buscou investigar como a infância e a masculinidade são apresentadas na narrativa de seis episódios deste desenho animado. Os resultados gerados no estudo revelaram que o este desenho animado é considerado como contemporâneo por não distinguir as fronteiras que caracterizam a infância e a vida adulta, visto que, nos episódios analisados, as atitudes de Bob Esponja e Patrick, seu melhor amigo, oscilam entre o mundo infantil e o mundo adulto (são ingênuos, moram sozinhos, divertem-se com brincadeiras infantis). Da mesma maneira, a identificação do gênero masculino apresenta formas tanto de jovem quanto de adulto, conforme os comportamentos manifestados como o choro e a sensibilidade, em que coexistem paradigmas que ainda permanecem na nossa sociedade.

Em vista do que foi percebido na análise dos vinte e três trabalhos acadêmicos que abordam a temática desenho animado e educação, pode-se afirmar que a categoria recursos pedagógicos teve maior representatividade, totalizando oito produções acadêmicas, que apresentaram como objetivo central o uso dos desenhos animados em sala de aula. Desses oito, seis estavam relacionados ao ensino de Ciências, conforme apresentado no quadro 1 a seguir.

Na categoria Concepções de Ciências, dos quatro trabalhos identificados, três deles abrangem a área de Ensino de Ciências. As ideias veiculadas pelos desenhos animados estudados retratam a imagem de Ciência como salvadora da humanidade, positivista e a-histórica e o cientista com estereótipos identificados como pessoa esquizofrênica, de notável inteligência, trajada com jaleco e privada do convívio social.

Na categoria Formação de valores e representação de violência, obtiveram-se um total de seis estudos, concentrados em dissertações de mestrado e teses de doutorado. Vale ressaltar que a área de conhecimento dessas produções restringe-se à Educação. Esse resultado apresentado sinaliza a importância de trabalhar a formação de valores como tema transversal e interdisciplinar no ensino de Ciências. Esse fato pode ser constatado também na categoria Representação de Gênero e Ciência, em que a maioria dos estudos abrange a área de Educação e somente um artigo internacional é da área de Ensino de Ciências. 
Quadro 1. Quadro síntese dos artigos, dissertações e teses identificados a partir das palavras-chaves desenho animado e educação utilizadas na revisão bibliográfica.

\begin{tabular}{|c|c|c|c|c|}
\hline Categorias & $\begin{array}{l}\text { Trabalhos/ } \\
\text { Estudos }\end{array}$ & Referência & $\begin{array}{c}\text { Área de } \\
\text { conhecimento }\end{array}$ & $\begin{array}{c}\text { Total de } \\
\text { trabalhos por } \\
\text { categoria }\end{array}$ \\
\hline \multirow{8}{*}{$\begin{array}{l}\text { Aspectos } \\
\text { pedagógicos }\end{array}$} & $\begin{array}{c}\text { Artigos } \\
\text { Nacionais }\end{array}$ & Ribeiro et al (2012) & Ensino de Ciências & \multirow[t]{8}{*}{20} \\
\hline & \multirow{4}{*}{$\begin{array}{c}\text { Artigos } \\
\text { internacionais }\end{array}$} & $\begin{array}{l}\text { Perales-Palacios e Vilchez- } \\
\text { González (2005) }\end{array}$ & Ensino de Ciências & \\
\hline & & $\begin{array}{l}\text { Vilchez-González e Perales- } \\
\text { Palacios (2005) }\end{array}$ & Ensino de Ciências & \\
\hline & & Piliouras etal (2011) & Ensino de Ciências & \\
\hline & & Hoban e Nielsen (2013) & Ensino de Ciências & \\
\hline & \multirow[t]{3}{*}{ Dissertações } & Xavier (2008) & Educação & \\
\hline & & Garcia (2009) & Educação & \\
\hline & & Silva (2011) & Ensino de Ciências & \\
\hline \multirow{4}{*}{$\begin{array}{c}\text { Concepções } \\
\text { de } \\
\text { Ciências }\end{array}$} & \multirow{2}{*}{$\begin{array}{c}\text { Artigos } \\
\text { nacionais }\end{array}$} & Mesquita e Soares (2008) & Ensino de Ciências & \multirow{4}{*}{4} \\
\hline & & Tomazi et al (2009) & Ensino de Ciências & \\
\hline & \multirow[b]{2}{*}{ Dissertações } & Bortoletto (2008) & Educação & \\
\hline & & Monteiro (2011) & Ensino de Ciências & \\
\hline \multirow{6}{*}{$\begin{array}{c}\text { Formação } \\
\text { de } \\
\text { valores } \\
\text { e } \\
\text { Representação } \\
\text { de violência }\end{array}$} & \multirow[t]{3}{*}{ Dissertações } & Wenzel (2002) & Educação & \multirow{6}{*}{6} \\
\hline & & Miranda (2009) & Educação & \\
\hline & & Leitão (2011) & Educação & \\
\hline & \multirow{3}{*}{ Teses } & Rocha (2005) & Educação & \\
\hline & & Mareuse (2007) & $\begin{array}{ll}\text { Educação } & \mathrm{e} \\
\text { Comunicação } & \end{array}$ & \\
\hline & & Silva (2010) & Educação & \\
\hline \multirow{5}{*}{$\begin{array}{c}\text { Representação } \\
\text { de } \\
\text { Gênero } \\
\text { e } \\
\text { Ciências }\end{array}$} & $\begin{array}{c}\text { Artigo } \\
\text { internacional }\end{array}$ & Brownlow e Durham (1997) & Ensino de Ciências & \multirow{5}{*}{5} \\
\hline & Dissertações & Medeiros (2010) & Educação & \\
\hline & \multirow{3}{*}{ Teses } & Kindel (2003) & Educação & \\
\hline & & Sabat (2003) & Educação & \\
\hline & & Santos (2010) & Educação & \\
\hline
\end{tabular}

Na categoria Representação de Gênero e Ciências, obteve-se um total de cinco estudos, quatro, em sua maioria, da área de Educação e somente um da área de ensino de Ciências. Os estudos pertencentes a essa categoria buscaram analisar e identificar as identidades de gênero de personagens de desenhos animados e filmes de animação e, também, aquelas ligadas ao trabalho do cientista e do professor, em que predominou o gênero masculino nessas representações.

Em relação ao tipo de abordagem, dos vinte e três estudos apresentados, quatorze trabalharam com os alunos como sujeitos de análise ${ }^{66}$, os quais os envolviam na pesquisa. Desses quatorze, onze utilizaram o desenho animado como instrumento de

\footnotetext{
${ }^{66}$ Participantes das pesquisas mencionadas em que foram avaliados os significados e/ou sentidos que os desenhos animados provocaram neles, diferindo os objetivos de cada estudo em questão.
} 
pesquisa e três realizaram a produção de desenhos tanto com alunos quanto com professores. Os demais estudos (nove) analisaram o desenho animado sobre as concepções de ciência ou a formação de valores.

A maioria (nove) dos estudos foi realizada em nível de mestrado na área de Educação, conforme apresentado no quadro 1. Em relação às seis teses identificadas, estas referem-se às categorias formação de valores e representação de violência e representação de gênero e ciência, conforme apresentado no quadro 1. Três delas apresentam a análise do desenho animado e as outras três utilizaram o desenho animado como instrumento de pesquisa que envolviam crianças e/ou alunos. Entretanto, nenhuma das teses apresentadas utilizou o desenho animado como recurso pedagógico no processo de ensino e aprendizagem de conceitos em contexto de sala de aula.

Sobre o tipo de desenho animado (comercial ou para fins educativos) utilizado nesses estudos, constatou-se que a maioria deles é comercial, ou seja, transmitidos por canais abertos ou fechados. Destacam-se aqueles que foram mais utilizados nas pesquisas (três vezes cada um): Bob Esponja, Calça Quadrada; Os Simpsons; Pokémon; Jimmy Neutron; e, duas vezes, o filme de animação $O$ Rei Leão, produzido pelos Estúdios Walt Disney. De alguma maneira, seja institucionalmente ou como parte da indústria de entretenimento, todos os desenhos são comerciais, tanto os que são transmitidos por canais televisivos quanto os exibidos em salas de cinema. Nas pesquisas que utilizaram o desenho como reforçador de valores ou como produto comercial, o foco de análise encontra-se no impacto de valores, estereótipos, padrões sobre a constituição histórico-cultural da criança. E, ainda, essas produções ressaltam o alcance dos desenhos como produto cultural que visa à fomentação de uma indústria do entretenimento, os impactos sociais produzidos pelos valores transmitidos nos desenhos e a influência na formação das crianças e dos jovens.

Os estudos de Xavier (2008), Piliouras et al (2010), Ribeiro et al (2012) e Hoban e Nielsen (2013), pertencentes à categoria recursos pedagógicos, produziram desenhos animados (ou curtas de animação) com fins educativos, realizado por alunos e/ou professores, para o desenvolvimento de conteúdos e conceitos científicos. Desses quatro estudos, dois (XAVIER, 2008; HOBAN; NIELSEN, 2013) trabalharam com conceitos do componente curricular de Biologia (ciclo de vida de inseto e meio ambiente) e os outros dois (PILIOURAS et al, 2010; RIBEIRO et al, 2012) com conceitos do componente curricular de Física (astronomia e força).

O estudo de Hoban e Nielsen (2013) foi o único trabalho em que o desenho animado foi produzido por professores de Anos Iniciais com a finalidade de ser 
utilizado na formação continuada de professores, que revisitaram conteúdos e confrontaram as concepções iniciais para a elaboração da animação. Os demais trabalhos (PERALES-PALACIOS; VILCHEZ-GONZÁLEZ，2005; VILCHEZGONZÁLEZ; PERALES-PALACIOS，2005; GARCIA，2009; SILVA，2011) da categoria recursos pedagógicos utilizaram desenhos comerciais (Astro Boy, Evolution, Os Simpsons e Pokémon) para desenvolver conceitos ou temas dos componentes curriculares de Biologia e Física.

Dentre os trabalhos acima citados, as três dissertações (XAVIER, 2008; GARCIA, 2009; SILVA, 2011) aproximam-se do presente estudo no que se refere ao uso do desenho animado em sala de aula com o objetivo de desenvolver temas ou conceitos na área de Biologia e a ocorrência da mediação nas atividades propostas. Esses estudos diferenciam-se pelo referencial teórico, sendo dois deles sobre a aprendizagem significativa (XAVIER, 2008; SILVA, 2011) e um (GARCIA, 2009) sobre linguagem, gêneros discursivos e narrativas, adotando Vigotski-Bathkin-Brunner como aporte teórico.

Diante dos resultados desta revisão bibliográfica, possibilita-se inferir que, até este ponto da pesquisa, os estudos descritos diferem da proposta do presente trabalho em quatro direções: o uso do desenho animado produzido e comercializado para fins educativos, a escolha do tema ecossistema, a articulação das informações apresentadas na narrativa com o processo de formação de conceito e, por último, ouso da teoria histórico-cultural como referencial teórico, porque apresenta elementos que explicam o processo complexo de formação de conceito.

Além disso, a partir dos resultados apresentados na revisão bibliográfica na categoria recursos pedagógicos, constatou-se que o uso de animações e/ou desenhos animados, especificamente no ensino de Ciências, ocorre de diversas formas, como motivação, discussão de temas, proposição de projetos, exploração de conteúdos disciplinares e interdisciplinares e, ainda, na produção e na elaboração de desenhos animados, utilizando softwares livres para temas específicos. 


\section{O PROCESSO DE FORMAÇÃO DE CONCEITO}

\section{PRESSUPOSTOS TEÓRICOS}

[...] o conceito surge no processo de operação intelectual; não é o jogo de associações que leva à obstrução dos conceitos: em sua formação participam todas as funções intelectuais elementares em uma original combinação, sendo que o momento central de toda essa operação é o uso funcional da palavra como meio de orientação arbitrária da atenção, da abstração, da discriminação de atributos particulares e de sua síntese e simbolização com o auxílio do signo (VIGOTSKI, 2009, p. 236).

Para o estudo da formação de conceitos, optou-se pela teoria de desenvolvimento histórico-cultural proposta por Lev S. Vigotski. Esta teoria pressupõe que o desenvolvimento das funções psíquicas superiores ocorre por meio de um processo histórico com base nas relações sociais entre o indivíduo e o mundo exterior, mediada por sistemas simbólicos presentes na cultura. $\mathrm{O}$ desenvolvimento do homem cultural adulto é resultante de um processo complexo que integra uma combinação de três trajetórias: "a da evolução biológica desde os animais até o ser humano, a da evolução histórico-cultural moderno, e a do desenvolvimento individual de uma personalidade específica (ontogênese)" (VYGOTSKY ${ }^{67}$; LURIA, 1996, p. 151).

O psicólogo soviético L. S. Vigotski nasceu em 1896 em Orsha, uma cidade localizada na Bielorrússia - antiga república constituinte da União Soviética e atualmente um país independente. Vigotski era o segundo filho de uma família composta por oito irmãos e passou a infância em Gomel, na Bielorrússia. Os pais eram bem instruídos e aparentemente com condições financeiras suficientes para manter tutores particulares e proporcionar uma educação de excelência para as crianças. Além disso, o apartamento em que moravam contava com uma biblioteca, o que pode ter estimulado nos filhos o apreço pela leitura (VAN DER VEER; VALSINER, 1999).

\footnotetext{
${ }^{67}$ Optou-se por manter a grafia do sobrenome do autor nas citações de acordo com a forma adotada pelos teóricos e tradutores em cada obra utilizada nesta pesquisa.
} 
Após a conclusão do ensino médio (antigo curso secundário), Vigotski ingressou no curso de Direito na Universidade de Moscou, em 1913. Concomitantemente, frequentou a Faculdade de História e Filologia da Universidade Popular de Shanyavskii (BLANCK, 2003). Logo após a conclusão do curso de Direito, passou a lecionar filosofia, literatura, lógica e psicologia. Apesar de Vigotski não ter formação acadêmica em Psicologia, sua brilhante formação multidisciplinar possibilitou a publicação de uma das suas primeiras obras, intitulada de Psicologia da Arte, em 1925. A publicação dessa obra o conduziu definitivamente para pesquisas em Psicologia. O filósofo Stephen Toulmin o chamava de Mozart da Psicologia, adjetivação que condiz com a notável contribuição de Vigotski à área: a teoria do desenvolvimento histórico-cultural (IVIC, 2010). Vigotski faleceu precocemente aos 38 anos, vítima de tuberculose (LURIA, 1994a).

Os trabalhos realizados por Vigotski incluem livros, artigos e conferências estenografadas, totalizando mais de 200 artigos publicados. Muitas obras são inéditas e ainda não foram publicadas nem mesmo na Rússia. No Brasil, os primeiros livros publicados, em ordem cronológica, são: A formação social da mente (1984), Pensamento e Linguagem (1987) e Linguagem, desenvolvimento e aprendizagem (1988), este último é uma coletânea de artigos produzidos por Vigotski, Alexander R. Luria e Alejskei N. Leontiev.

De acordo com Prestes (2010), o meio acadêmico brasileiro veio a ter contato com suas obras, aproximadamente, na década de 1980. Um dos primeiros livros a serem traduzidos foi uma versão resumida de Pensamento e Linguagem (1987), traduzido do inglês e não do russo, sendo a última obra a ser escrita pelo autor. A última edição deste livro foi publicada no Brasil em 2009, com o título A construção do pensamento e da linguagem, pela mesma editora. Em comunicação pessoal com Zoia Prestes, o tradutor Paulo Bezerra disse que alterou o título para diferenciar sua tradução da versão que foi publicada nos Estados Unidos e trazida para o Brasil (PRESTES, 2010). Do ponto de vista de Duarte (2001, p. 9), a solução adotada pela editora de acrescentar a palavra construção ao título do livro resultou em dois equívocos: não esclarece que se trata da edição com o texto integral e, ainda, produz "de forma deliberada ou não, uma associação entre a teoria vigotskiana e o Construtivismo".

A importância dessa obra supracitada para o presente trabalho refere-se aos dois capítulos que versam sobre o estudo experimental e o desenvolvimento dos conceitos no pensamento infantil. Vigotski (2009) destaca que este processo de formação de conceitos envolve uma série de funções psíquicas superiores e o estudo é relevante em 
função da complexidade do processo de desenvolvimento dos conceitos científicos que não podem ser simplesmente assimilados.

Esse processo de desenvolvimento dos conceitos ou significados das palavras requer o desenvolvimento de toda uma série de funções como a atenção arbitrária, a memória lógica, a abstração, a comparação e a discriminação, e todos esses processos psicológicos sumamente complexos não podem ser simplesmente memorizados, simplesmente assimilados (VIGOTSKI, 2009, p. 246).

O estudo do desenvolvimento dos conceitos científicos é somente uma parte do processo complexo que integra o desenvolvimento das funções psíquicas superiores. Cabe ressaltar que, antes de explicitar sobre a formação de conceitos, a priori destacamse os principais conceitos da teoria de desenvolvimento histórico cultural que estão imbricados no processo de formação de conceitos.

Vygotsky (1997) destaca que a Psicologia vigente na época tratava todas as funções psíquicas citadas (elementares e superiores) como sendo um mesmo processo e a formação dessas funções era vista como um processo natural, determinado biologicamente, em que não existia a influência das atividades culturais e sociais. Para o autor, no processo geral de desenvolvimento, existem duas linhas diferentes tanto qualitativamente quanto as suas origens, que são definidas como as funções psíquicas elementares (processos elementares), as quais são de origem biológica; e as funções psíquicas superiores (processos superiores), as quais são de origem sociocultural (VIGOTSKI, 1998).

A visão de desenvolvimento preponderante na época era "mecanicista", ou seja, a existência de um processo complexo era o resultado da soma de elementos separados ou de outras partes. A teoria histórico-cultural proposta por Vigotski apoiava-se nos pressupostos do materialismo dialético de autores como Karl Marx e Friedrich Engels:

A síntese de dois elementos não é a simples soma ou justaposição desses elementos, mas a emergência de algo novo, anteriormente inexistente. Esse componente novo não estava presente nos elementos iniciais foi tornado possível pela interação (OLIVEIRA, 1997, p. 23).

O processo de desenvolvimento não era a soma dos elementos, mas a síntese de elementos presentes na história do desenvolvimento da espécie (filogênese) resultante da interação entre o natural (biológico) e o social (cultural). O comportamento humano é moldado pela interação tanto das características biológicas quanto do seu meio social. A conduta do ser humano seria um tipo de conduta superior, ou seja, um 
comportamento novo em decorrência do uso e do emprego de ferramentas, que se distingue da adaptação biológica, e que surgiu em um período histórico da humanidade, mas que tem um processo próprio e diferenciado, tanto em relação às vias de desenvolvimento como às raízes (VYGOTSKY, 1997).

O desenvolvimento das funções psíquicas superiores - FPS integra tanto o processo natural quanto os meios externos determinados pela cultura. Vygotsky (1997) assinala que ocorrem duas vias de desenvolvimento das FPS e que estas jamais se fundem, mas estão indissoluvelmente unidas:

Trata-se, em primeiro lugar, de processos de domínio dos meios externos de desenvolvimento cultural e de pensamento: a linguagem, a escrita, o cálculo, o desenho; e, em segundo, dos processos de desenvolvimento das funções psíquicas superiores especiais, não limitadas nem determinadas com exatidão, que na psicologia tradicional se denominam atenção voluntária, memória lógica, formação de conceitos etc. (VYGOTSKY, 1997, p. 15, tradução nossa).

Para o autor, o conjunto dos processos de desenvolvimento cultural e das funções psíquicas especiais é considerado como processo de desenvolvimento das formas superiores de conduta da criança. Essa forma superior inaugura novas formas de comportamento que diferenciam um adulto cultural, por exemplo, dos animais (VYGOTSKY; LURIA, 1996)

Neste trabalho, adota-se uma definição de cultura conforme proposta por Santos (2007), para embasar a relevância da cultura no processo de desenvolvimento humano.

Cultura é uma dimensão do processo social, da vida de uma sociedade. [...] Cultura é uma construção histórica, seja como concepção, seja como dimensão do processo social. Ou seja, a cultura não é algo natural, não é uma decorrência de leis físicas ou biológicas. Ao contrário, a cultura é um produto coletivo da vida humana. Isso se aplica não apenas à percepção da cultura, mas também à sua relevância, à importância que passa a ter. Aplica-se ao conteúdo de cada cultura particular, produto da história de cada sociedade (SANTOS, 2007, p. 44-45).

Como exemplo da influência cultural no desenvolvimento humano, pode-se citar os estudos realizados por Luria (1994b) sobre os processos de pensamento em povos de aldeias e campos nômades do Uzbequistão e da Khirgizia, na Ásia Central. O intuito era descrever as mudanças nos processos de pensamento provocadas pela evolução social e tecnológica que ocorria na época (início da década de 1930). Após o desenvolvimento de atividades de classificação, abstração, o autor concluiu que "mudanças nas formas 
práticas de atividade, e especialmente a reorganização da atividade baseada na escolaridade formal, produziram alterações qualitativas nos processos de pensamento dos indivíduos estudados" (Idem, p. 58).

As mudanças qualitativas que possibilitam o suporte para estágios precedentes dentro de um mesmo processo de desenvolvimento e pela sua natureza são consideradas como transformações históricas. Nas crianças, esse processo de desenvolvimento das FPS inicia-se com atividades que, posteriormente, se transformam em atividades com signos ou operações com signos (VIGOTSKI, 1998).

De acordo com Leontiev (1994), a atividade é designada como:

[...] os processos psicologicamente caracterizados por aquilo a que o processo, como um todo, se dirige (seu objeto), coincidindo sempre com o objetivo que estimula o sujeito a executar esta atividade, isto é, o motivo (LEONTIEV, 1994, p. 68).

Os processos de atividade são apenas aqueles que, "realizando as relações do homem com o mundo, satisfazem uma necessidade especial correspondente a ele" (LEONTIEV, 1994, p. 68). Outro conceito como operações é definido por esse autor como o modo de execução de um ato e explicita a diferença entre a operação e a ação:

Uma operação é o conteúdo necessário de qualquer ação, mas não é idêntico a ela. Uma mesma ação pode ser efetuada por diferentes operações e, inversamente, numa mesma operação podem-se, às vezes, realizar diferentes ações: isto ocorre porque uma operação depende das condições em que o alvo da ação é dado, enquanto uma ação é determinada pelo alvo (LEONTIEV, 1994, p. 74).

Vigotski acreditava que as operações mentais com a utilização de signos são produto das condições específicas do desenvolvimento social e cultural. Os signos são estímulos artificiais, ou autogerados, que permitem ampliar as operações de memória para além daquelas determinadas biologicamente pelo sistema nervoso. As atividades com o uso de signos mostram que a diferença entre o ser humano e as outras espécies de animais superiores é a introdução desses signos, que significa uma forma inteiramente nova de comportamento (VIGOTSKI, 1998). Os hieróglifos, as palavras, o uso de instrumentos são exemplos de signos que permitem ampliar a memória e auxiliar o desempenho das funções psíquicas superiores (atividades psicológicas).

O desenvolvimento das FPS na criança é um processo único, que pode ser determinado pela seguinte lei fundamental de desenvolvimento: 
Todas as funções psicointelectuais superiores aparecem duas vezes no decurso do desenvolvimento da criança: a primeira vez, nas atividades coletivas, nas atividades sociais, ou seja, como funções interpsíquicas: a segunda, nas atividades individuais, como propriedades internas do pensamento da criança, ou seja, como funções intrapsíquicas. (VIGOTSKII, 1994, p. 114).

Desta forma, as FPS não podem ser definidas como uma continuação do desenvolvimento das funções elementares, ou seja, as FPS desenvolvem-se a partir do entrelaçamento entre as funções interpsíquicas (atividades sociais) e as intrapsíquicas (atividades internas do pensamento).

No estudo da história do desenvolvimento das funções psíquicas superiores, existiram diversos problemas, como a ausência de uma definição clara e uma metodologia própria, além da não diferenciação da gênese das funções elementares e das superiores (VYGOTSKY, 1997). As funções elementares deveriam ser o ponto de partida para a elaboração de experimentos desenvolvidos dentro de uma perspectiva histórica, objetivando estabelecer como ocorre o processo de desenvolvimento das FPS.

A preocupação de Vigotski com os métodos empregados para o estudo do desenvolvimento das FPS estende-se, também, aos tipos de métodos utilizados para a formação de conceitos já que envolve uma das funções psíquicas superiores, a abstração. Vygotsky e Luria (1996, p. 201) definem a abstração como uma parte integrante e necessária a todo tipo de processo de pensamento, "uma técnica criada no processo de desenvolvimento da personalidade, e condição e instrumento necessário de seu pensamento".

Vigotski (2009) assegura que a maior dificuldade no campo do estudo dos conceitos foi a ausência de uma metodologia experimental que permitisse penetrar a fundo no processo de formação dos conceitos, estudar a sua gênese e a sua natureza psicológica. Medin (1989) apud Marcos Oliveira (1999) propôs uma classificação dos períodos que ocorreram as investigações sobre os conceitos, sendo cada período correspondente à concepção sobre a natureza do conceito. O primeiro período é o da concepção clássica, que compreende desde Aristóteles até o início da década de 1970 do século XX; o segundo período é o da concepção prototípica que compreende a década de 1970 até 1985 e, por último, o terceiro período é o da concepção teórica, de 1985 até os dias atuais.

Para o autor, na concepção clássica, os conceitos possuem uma natureza binária (tipo tudo ou nada), "absolutamente precisa" e definida "por uma lista de propriedades necessárias e suficientes" (OLIVEIRA, Marcos, 1999, p. 18). Esta concepção 
fundamenta-se na lógica aristotélica ${ }^{68}$ e predominou ao longo de quase toda a história da lógica e da filosofia, com um número enorme de teorizações que não foram questionadas.

Em outra perspectiva, na concepção prototípica - também conhecida como concepção probabilística ou concepção natural - os conceitos possuem uma natureza contínua ou gradual, são identificados como conjuntos de propriedades, mas estas "não são necessárias e suficientes", constituindo o protótipo como a aplicabilidade de um conceito:

[...] uma entidade depende do grau de similaridade que existe entre a entidade e o protótipo do conceito. Em função deste grau, a entidade ou não será um exemplar do conceito, ou será um caso limítrofe, ou será um exemplar - menos ou mais típico (OLIVEIRA, Marcos, 1999, p. 22).

Em contraposição, na concepção teórica, a definição de conceito consiste tanto no conjunto de propriedades quanto na relação com outros conceitos:

[...] um conceito é constituído não apenas de propriedades, mas também de relações com outros conceitos. Os conjuntos dessas relações que articulam os conceitos entre si formam redes, as quais são vistas como teorias. Por "teorias", neste contexto, deve-se entender não apenas teorias científicas, mas também estruturas cognitivas do senso comum (OLIVEIRA, Marcos, 1999, p. 26).

Para explicar o significado de teoria nesse contexto, o autor cita o exemplo de um adulto que não passou pelo ensino formal, mas tem conhecimento sobre o ciclo de vida, alimentação e procriação de um animal e as ideias desse adulto sobre certo animal formariam o senso comum ${ }^{69}$. No artigo de Marta Oliveira, intitulado Três questões sobre o desenvolvimento conceitual, a autora também explicita que, na abordagem teórica, "os conceitos não são entidades isoladas na mente do sujeito, mas estão organizados em algum tipo de todo estruturado, uma rede de significados, em que há relações entre os elementos" (OLIVEIRA, Marta, 1999, p. 59). Quando um adulto é questionado sobre algo, a resposta pode ser explicitada em forma de teoria, na tentativa de manifestar e organizar o conhecimento adquirido ao longo da vida.

A partir da já citada classificação dos períodos históricos em que ocorreram os estudos de conceitos (OLIVEIRA, Marcos, 1999), é possível perceber que os

\footnotetext{
${ }^{68} \mathrm{~A}$ lógica aristotélica é um instrumento criado pelo filósofo Aristóteles $(384-321$ a. C) para verificar a validade ou não de raciocínios lógicos.

${ }^{69}$ Neste caso, o senso comum seriam as teorias utilizadas por um adulto para explicar o seu conhecimento sobre algo.
} 
experimentos de Psicologia desenvolvidos por Vigotski e seus colaboradores, na década de 1920 e 1930, para estudar a formação e o desenvolvimento de conceitos, utilizaram como pressuposto a concepção clássica sobre a natureza do conceito, considerando o período que compreende desde Aristóteles até a década de 1970. Os métodos tradicionais de estudo dividiam-se em dois grupos básicos: o método da definição - que permite investigar os conceitos já formados na criança por meio da definição verbal de seus conteúdos e o segundo, o método de estudo da abstração, também conhecido como método direto, que estuda as funções e os processos psicológicos que fundamentam o processo de formação de conceitos com base na elaboração da experiência direta da qual nasce o conceito.

Van der Veer e Valsiner (1999) comparam o método da definição com o método direto:

[...] enquanto o método da definição tenta compreender o processo de formação de conceitos em um plano puramente verbal, isolados dos objetos concretos a que os conceitos se referem, o método direto investiga a formação de conceitos na esfera puramente prática, isolando-a do papel orientador das palavras (VAN DER VEER; VALSINER, 1999, p. 284).

Além disso, esses autores assinalam que o método de busca modificado desprezava que cada novo nível de desenvolvimento da generalização se apoiava na generalização dos níveis precedentes. Os autores explicam, no trecho abaixo, como isso ocorria no método de busca modificado e aplicado nas pesquisas de Vigotski:

Esse inconveniente era causado, Vygotsky raciocinou, pela montagem do experimento, que não proporcionava a explicação da relação entre os diferentes níveis de pensamento conceitual e a transferência de um nível para outro, nem a compreensão das relações de generalidade, uma vez que, de acordo com a lógica do experimento, o sujeito (1) tinha que reiniciar todo o processo após cada tentativa de agrupar os objetos, anulando, desta forma, o trabalho feito e as generalizações encontradas, e (2) tinha que trabalhar com conceitos de um nível bastante baixo. A investigação de conceitos na vida real visava a corrigir esses inconvenientes e, em particular, a demonstrar a maneira como o ambiente podia direcionar o desenvolvimento de conceitos das crianças (VAN DER VEER; VALSINER, 1999, p. 294).

Esses métodos simplificam o complexo processo de formação de conceitos e dissociam a palavra da matéria concreta. Entretanto, no processo de formação de conceitos, a palavra empregada como signo desempenha papel primordial em função da sua aplicabilidade e da inter-relação na elucidação das diferentes fases do processo de 
formação de conceitos (pensamento sincrético, pensamento por complexos e pensamento conceitual).

Outro método de estudo de formação de conceitos, proposto por Narziss Ach, denominado método de busca, incluía, na elaboração do conceito, tanto o objeto concreto quanto a palavra. Vigotski o considerou como método sintético-genético porque estudava a formação de conceitos desde a elaboração, o desenvolvimento e a síntese de uma série de traços que formam o conceito. Todavia, esse método não elucidou o processo genético de formação de conceito, ou seja, as palavras experimentais que desempenharam o papel de signos não se modificaram durante o experimento, assim como o seu modo de aplicação (VIGOTSKI, 2009). Os resultados gerados na investigação evidenciaram que, cada vez que o sujeito tinha de reiniciar o processo, não era possível compreender quais os critérios utilizados para agrupar os objetos na elaboração das generalizações durante o experimento.

Para o estudo efetivo da formação de conceitos, Vigotski e o seu colaborador, Leonid S. Sakharov, modificaram o método de busca de Narziss Ach, como já exposto anteriormente, e adaptaram o uso do método funcional da dupla estimulação sob a influência dos novos pressupostos de Vigotski sobre o desenvolvimento das formas superiores de comportamento (SAKHAROV, 1994).

A princípio, o método funcional da dupla estimulação foi usado por Francis Aveling, psicólogo canadense, com o objetivo de descrever fenomenologicamente " "a experiência interior do significado dos conceitos já formados" e não para o estudo da formação de conceito (SAKHAROV, 1994, p. 91). O método funcional da dupla estimulação pode ser definido com base em dois momentos, como apresentados por Vigotski:

O problema é desenvolvido inteiramente desde o primeiro momento da experiência diante do experimentando e assim permanece ao longo de cada etapa da experiência. E o segundo momento, os meios de solução do problema os signos-estímulos ou palavras vão sendo introduzidos gradualmente a cada tentativa empreendida pelo sujeito para resolver o problema com as palavras insuficientes anteriormente propostas (VIGOTSKI, 2009, p. 164).

No método de Ach, a organização da série de objetos é apresentada de uma forma simétrica. Para Sakharov (1994), a tarefa executada pelas crianças, no

\footnotetext{
${ }^{70}$ De acordo com Japiassu e Marcondes (1996, p. 101), a fenomenologia é uma "corrente filosófica fundada por E. Husserl, visando estabelecer um método de fundamentação da Ciência e de constituição da filosofia como ciência rigorosa. O projeto fenomenológico se define como uma 'volta às coisas mesmas', isto é, aos fenômenos, aquilo que aparece à consciência, que se dá como seu objeto intencional”.
} 
experimento de Ach, não contribuiu para esclarecer a interação entre o estímulo objeto e o estímulo verbal em função da disposição dos objetos de uma forma simétrica. $\mathrm{O}$ autor ainda destaca que seria mais conveniente apresentar para a criança um mundo objetivo desorganizado em que a relação dos objetos com as palavras seria a reação da criança ao utilizar e ao empregar a palavra para tentar organizar os objetos apresentados em uma tarefa.

O interesse não era a tarefa em si, mas como os significados das palavras (signos verbais) organizam as reações dos indivíduos dentro de uma situação artificial. Para isso, Sakharov (1994) define o princípio básico para o delineamento do experimento:

[...] é que a série de objetos é dada de forma completa no início do jogo, mas a série verbal é aumentada gradualmente; todos os novos itens da série entram no jogo, gradualmente, um por um. Após cada mudança na série verbal, isto é, depois de cada mudança na natureza da dupla estimulação, a criança dá-nos a sua reação livre, com base na qual podemos avaliar o grau de utilização funcional dos itens na série verbal e as reações psicológicas da criança para a série de objetos (SAKHAROV, 1994, p. 96, tradução nossa).

A organização do experimento permitiu avaliar o "grau" em que as crianças fazem uso das palavras. Com base nos resultados desse experimento, utilizando o método funcional da dupla estimulação, Sakharov (1994) observa que, na formação de conceitos, a palavra passa por três fases: a primeira é um signo individual com seu próprio nome; a segunda torna-se um signo de família associado a uma série de objetos concretos e, por último, o processo de abstração (conceituação).

\subsection{Os tipos de pensamento identificados nos estudos sobre formação de conceitos}

Neste estudo, optou-se por utilizar o termo tipo, conforme a observação levantada por Tunes (1995, p. 32), pelo fato de que “[...] na psicologia do desenvolvimento, tem sido comum utilizar aqueles termos numa perspectiva linear de progressão em que um determinado estágio (ou fase) segue, temporalmente, um outro e o substitui". Além disso, de acordo com os pressupostos teóricos de Vigotski, os diferentes tipos de pensamento podem coexistir:

[...] mesmo depois de ter aprendido a operar com forma superior de pensamento - os conceitos -, a criança não abandona as formas mais elementares, que durante muito tempo ainda continuam a ser qualitativamente predominantes em muitas áreas do seu pensamento (VIGOTSKI, 2009, p. 228). 
No momento, a intenção é definir cada tipo de pensamento e os respectivos subtipos. Os exemplos aqui citados para ilustrar os tipos e/ou subtipos são resultantes da pesquisa realizada por Queiroz (2007), com o objetivo de verificar a função pedagógica da imagem (fixa) na aprendizagem do conceito de animal. Convém lembrar que os exemplos citados abarcam os tipos, mas nem todos os subtipos identificados por Vigotski, em função da diferença dos objetivos e das situações experimentais de cada estudo em questão.

A partir dos resultados das investigações, Vigotski e seus colaboradores concluíram que o processo de desenvolvimento dos conceitos evolui em três fases: o pensamento sincrético, o pensamento por complexos e, a terceira e última, o pensamento conceitual (VIGOTSKI, 2009).

\subsubsection{O pensamento sincrético}

O pensamento sincrético é caracterizado como amontoado ou agregação desordenada, que corresponde às experiências vivenciadas. Este tipo caracteriza-se pelo agrupamento de objetos realizado ao acaso e se subdivide em três subtipos de acordo com a formação da imagem sincrética: a formação da imagem sincrética ou amontoado de objetos; a formação da imagem sincrética pela percepção direta e imediata; e, a formação da imagem sincrética em uma base complexa.

A formação da imagem sincrética ou amontoado de objetos é correspondente ao significado das palavras, subtipo no qual os agrupamentos são construídos pelo processo de tentativa e erro no pensamento infantil em que os novos objetos são escolhidos ao acaso. A imagem sincrética, por sua vez, formada pelo contato ou pela percepção imediata, é um subtipo no qual os agrupamentos dos objetos são formados com base em vínculos subjetivos da percepção imediata da criança. E, por último, a formação da imagem sincrética em uma base complexa, subtipo no qual a formação "se apóia na atribuição de um único significado aos representantes dos diferentes grupos unificados" por meio da percepção da criança (VIGOTSKI, 2009, p. 176-177).

Neste último subtipo, os agrupamentos são feitos com base nos agrupamentos formados nos dois subtipos anteriores. A diferença, em relação às fases anteriores, é que o representante de algum grupo de objetos unificados, por meio da percepção da criança, não conserva nenhuma relação interna entre eles e os objetos representam o mesmo nexo desconexo do amontoado que os equivalentes dos conceitos nas duas fases anteriores. Assim, a complexidade consiste na "elaboração biestadial" dos vínculos sincréticos, primeiramente "formam-se os grupos sincréticos, de onde representantes 
particulares se separam para tornar a reunificar-se sincreticamente" (VIGOTSKI, 2009, p. 177-178).

Para ilustrarmos esse tipo, citaremos o exemplo da entrevista de uma criança (C1), realizada por Queiroz (2007), que solicitou a ela que separasse as imagens em dois grupos (seres vivos e seres não vivos) e colocou a figura do celular no grupo dos seres vivos. O significado atribuído para classificar o objeto no grupo dos seres vivos estava relacionado ao critério movimento associado ao comportamento. A seguir, o trecho transcrito da entrevista em que a criança (C1) explica à entrevistadora (E) o que a leva a incluir o celular no grupo dos seres vivos:

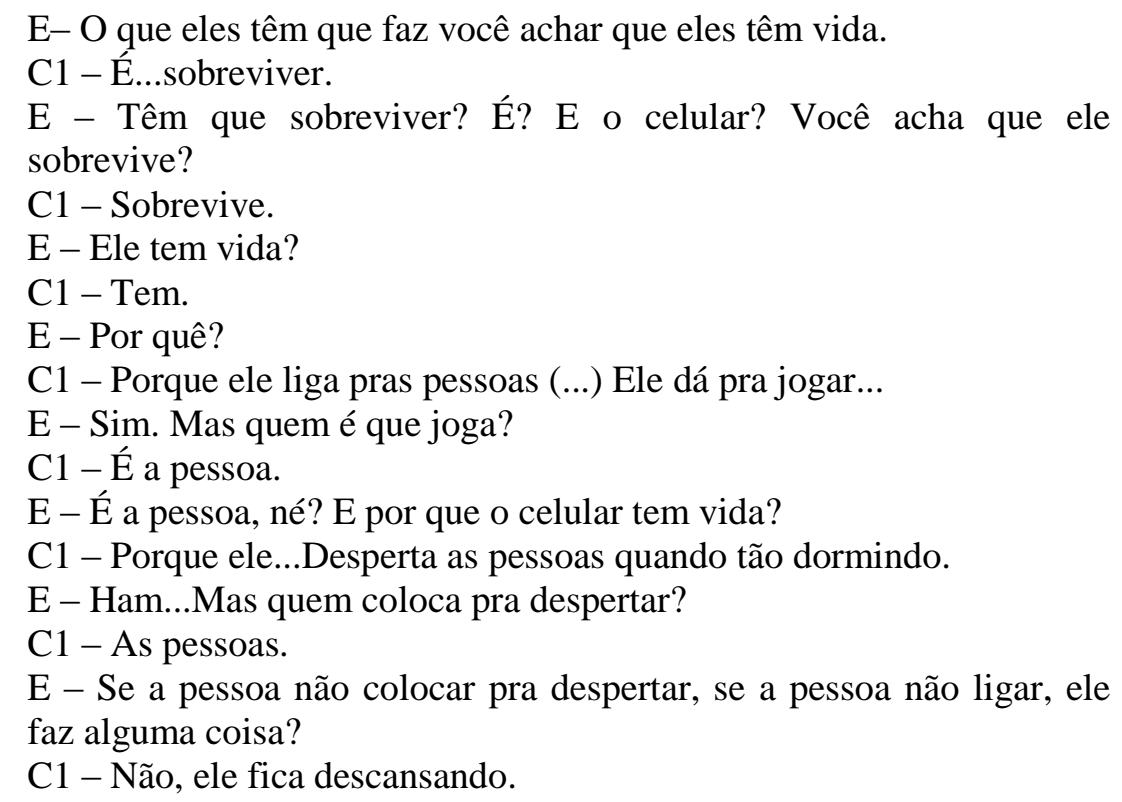

(Trecho da entrevista com a criança C1) (QUEIROZ, 2007, p. 105)

Para a autora, o trecho acima evidencia a influência dos costumes de um povo por exemplo, os adultos têm o costume de colocar alguma coisa para descansar como a massa de pão ou os aparelhos eletrodomésticos (o ferro para "esfriar" após ser usado) em relação ao desenvolvimento da criança (QUEIROZ, 2007).

\subsubsection{O pensamento por complexos}

O segundo tipo denomina-se pensamento por complexos, que consiste em combinar objetos e impressões concretas dos objetos em grupos especiais que, estruturalmente, lembram o que costumamos chamar de coleções. Uma das principais diferenças em relação ao tipo anterior é o estabelecimento de vínculos objetivos (relações entre diferentes impressões concretas), demonstrando o início de uma sistematização do pensamento da criança com base na sua experiência imediata. Para o 
autor, esse tipo marca o início de um pensamento superior, coerente e objetivo em que a "criança começa a unificar objetos homogêneos em um grupo comum e a complexificálos segundo as leis dos vínculos objetivos que ela descobre em tais objetos" (VIGOTSKI, 2009, p. 179).

O pensamento por complexos subdivide-se em cinco subtipos: complexo associativo, complexo de coleções, complexo em cadeia, complexos difusos e pseudoconceito.

O complexo associativo é o subtipo no qual a criança agrupa os objetos com base em qualquer vínculo associativo observado por ela no objeto e, a partir desse vínculo, a criança pode estabelecer relações concretas com outros objetos e incluir em um grupo e denominar um nome próprio, tornando-se nomes de família.

O complexo de coleções é o subtipo no qual a criança combina os objetos e as impressões concretas em grupos especiais, organizadas nas chamadas "coleções" (VIGOTSKI, 2009).

O complexo em cadeia é o subtipo no qual a criança agrupa os objetos segundo o princípio da combinação dinâmica e temporal de determinados elos em uma cadeia única e "da transmissão do significado através de elos isolados dessa cadeia". Vigotski cita como exemplo o uso da palavra quá por uma criança:

[...] primeiro para designar um pato nadando em um lago, depois qualquer espécie de líquido, inclusive o leite em sua mamadeira; posteriormente, quando por acaso vê uma moeda com um desenho de águia, a moeda também é chamada de quá, designação que a partir daí ela aplica a qualquer objeto redondo com semelhança de moeda (VIGOTSKI, 2009, p. 204).

Neste subtipo, a cada objeto novo, a criança inclui algum atributo em comum referente a outro elemento, podendo o primeiro sofrer alterações infinitas.

O complexo difuso é o subtipo no qual a criança agrupa os objetos com base na combinação de vínculos difusos e indefinidos dos grupos diretamente concretos, seja de imagens, seja de objetos.

Por último, o pseudoconceito é o subtipo caracterizado pela transição entre o pensamento por complexos e o pensamento conceitual, a criança constrói uma generalização com base em vínculos diretos, fatuais e concretos, como numa simples associação. Embora o pseudoconceito seja semelhante ao verdadeiro conceito, esse difere deste último pela sua essência, pela natureza genética, pelas condições de surgimento e de desenvolvimento e pelos vínculos dinâmico-causais que lhe servem de 
base (VIGOTSKI, 2009). Para ilustrar esse subtipo, será usado o trecho transcrito da entrevista realizada com a criança (C10) por Queiroz (2007) na atividade com o uso de imagens para agrupar os animais de acordo com as semelhanças. A criança C10 utiliza, para cada grupo formado, um critério diferente, como tamanho, aparência física e lugar (por exemplo, animais que vivem na água):

E - Dos que você acha que são seres vivos, você vai separar só os animais.

C10 - O lobo...Um animal...Esse aqui é um animal? É um animal...

E - Golfinho é animal?

C10 - É...Só as coisas grandes que é animal.

$\mathrm{E}-\mathrm{E}$ os que são pequenos?

C10 - Tem uns que são pequenos e são animais. Abelha não é um animal.

E - (...) Por que a abelha não é animal?

C10 - Por que ela não é grande... Também... Que ela não faz as mesmas coisas que animal...(...)

$\mathrm{E}$ - $\mathrm{O}$ que você conhece pequeno que é um animal?

C10 - Animal...É assim: cavalo, boi, vaca...Esses assim...

$\mathrm{E}-\mathrm{Ah}$ ! E esses aqui são o quê? A abelha, besouro, sanguessuga...

C10 - Ué! Isso daí é insetinho. Insetos.

$\mathrm{E}-\mathrm{Ah}$ ! São insetos. E os insetos não são animais?

C10 - Não.

(Trecho da entrevista com a criança C10) (QUEIROZ, 2007, p. 142)

Conforme o exemplo citado acima, a criança C10 conseguiu estabelecer "grupos categóricos" aproximados da taxonomia científica vigente, podendo ser considerado como uma transição do pensamento por complexos (concreto) para o pensamento conceitual (abstrato) devido a sua lógica de classificação em considerar somente os mamíferos como animais. Queiroz (2007) destaca que as crianças relutam em abandonar as relações com as situações práticas-concretas vivenciadas, o que indica a transição entre os dois tipos de pensamento (concreto e abstrato).

Os pseudoconceitos são a forma predominante e mais propagada em relação aos outros subtipos de pensamento por complexos. Além disso, são a forma mais frequente de pensamento na idade pré-escolar. A propagação se deve ao fato de que o pensamento por complexos na fase infantil corresponde ao significado das palavras, sendo estes significados determinados neste subtipo pelas palavras utilizadas no discurso dos adultos e não pelo próprio desenvolvimento da criança. Este fato só foi percebido em função do desenvolvimento do experimento, que libertava a criança da influência do discurso do adulto, ou seja, da linguagem verbal que a rodeia.

Vigotski explica a origem dessa concepção da equivalência funcional do pseudoconceito com o conceito: 
A criança aprende muito cedo um grande número de palavras que significam para ela o mesmo que significam para o adulto. A possibilidade de compreensão cria a impressão de que o ponto final do desenvolvimento do significado das palavras coincide com o ponto inicial, de que o conceito é fornecido pronto desde o princípio e que, consequentemente, não resta lugar para o desenvolvimento (VIGOTSKI, 2009, p. 194, grifo do autor).

Dessa maneira, a formação de conceitos no pensamento infantil desenvolve-se gradualmente juntamente ao significado da palavra. A criança assimila as palavras desde a sua tenra idade em um universo de palavras que as rodeiam e em função da influência exercida pelo seu meio social.

\subsubsection{O pensamento conceitual}

O terceiro tipo é o pensamento conceitual propriamente dito. O pensamento conceitual pressupõe a discriminação, a capacidade de abstração e o isolamento de determinados elementos para a formação do conceito (VIGOTSKI, 2009). Esse tipo subdivide-se em três subtipos: agrupamento por grau máximo de semelhança; agrupamento com base em um único atributo $^{71}$ (conceitos potenciais) e os conceitos verdadeiros.

O subtipo agrupamento por grau máximo de semelhança é muito próximo do pseudoconceito. Ocorre uma unificação dos diferentes objetos concretos, constituída a partir da máxima semelhança entre eles. Como essa semelhança nunca é completa, Vigotski (2009, p. 220-221) verificou uma situação psicológica interessante em que "a criança coloca os diferentes traços de um dado objeto em condições diferentemente favoráveis quanto à atenção".

Os traços que refletem em seu conjunto o máximo de semelhança com o modelo que lhe foi dado colocam-se como que no centro da atenção, assim se destacam e são abstraídos dos demais traços que permanecem na periferia da atenção. Pela primeira vez aqui se manifesta com toda nitidez um processo de abstração que frequentemente mal se consegue distinguir, porque, por uma simples e vaga impressão de identidade e não por uma discriminação precisa de determinados atributos, às vezes se abstrai um grupo de atributos internamente decompostos de forma precária (VIGOTSKI, 2009, p. 221).

O subtipo agrupamento com base em um único atributo também é denominado estágio de conceitos potenciais. Em situação experimental, “a criança [...] costuma destacar um grupo de objetos que ela generaliza depois de reunidos segundo um atributo

\footnotetext{
${ }^{71}$ Segundo o Houaiss (2009), atributo é o que é próprio e peculiar a alguém ou a alguma coisa.
} 
comum" (VIGOTSKI, 2009, p. 222). Porém, diferentemente do pensamento por complexos, o atributo que serve de base à criança para a inclusão do objeto "é um atributo privilegiado e abstraído do grupo concreto de atributos aos quais está efetivamente vinculado" (VIGOTSKI, 2009, p. 225).

Para ilustrar esse subtipo, será usado o trecho transcrito da entrevista realizada com uma criança (C5) por Queiroz (2007) na atividade com o uso de imagens para agrupar os animais de acordo com as semelhanças. Neste caso, as imagens conferiram uma função pedagógica e auxiliar que contribuiu para que a criança pudesse isolar uma característica (mamas) presente em um determinado animal e transferi-la para outros do mesmo grupo:

E - Você viu aqui nessa imagem e disse que é o galo e a galinha. Não é isso? E aqui? Você consegue me dizer? Quem é quem aí?

C5 - A vaca e o boi (aponta para a vaca e o boi).

$\mathrm{E}$ - Como você sabe?

C5 - Tem esses negócios.

E - Como chamam esses negócios que você mostrou com o dedinho?

C5 - Mama.

E - Mamas. A vaca tem as mamas. E o boi? Tem o quê? (...) Silêncio.

Boi tem mama?

C5 - Hum hum (não).

$\mathrm{E}$ - Não? O que ele tem?

C5 - Pele.

E - Pele? Você não está vendo nada diferente pra dizer que ele é um boi?

C5 - Eu to vendo.

E - O que você está vendo? Mostra!

C5 - (Aponta os testículos do boi)

$\mathrm{E}-\mathrm{Ah}$ ! Sabe como é que chama isso aí?

C5 - Hum hum (não).

E - São os testículos do boi. Olha deste aqui. O que você acha que ele

é? (Referindo-se à imagem de uma vaca com as mamas vazias).

C5 - Boi também.

$\mathrm{E}$ - Como você sabe que é boi?

C5 - Ele tá aguado...Esse negócio aqui (mostra os testículos do boi da outra imagem).

E - Os testículos? Esse aqui tem testículos?

C5 - Tem. Só que não dá pra ver.

E - Será? Não tem nada dando pra ver aí? O que é isso aqui? (Mostrou as mamas vazias da vaca).

C5 - É uma vaca.

$\mathrm{E}-\mathrm{E}$ uma vaca. Isso mesmo. Aqui é a mama da vaca. Só que não está cheia. Que você acha que tem dentro da mama da vaca?

C5 - Leite.

E - Leite! Muito bem. Tem mais algum animal que dá leite?

C5 - Veado...Deixa eu ver...Cachorro.

$\mathrm{E}-$ Cachorro. Muito bem. Mais algum que dá leite?

C5 - Canguru.

(Trecho da entrevista com a criança C5) (QUEIROZ, 2007, p. 147- 
A autora também destaca que o uso das imagens, tanto como instrumento psicológico como signo linguístico, contribuiu para que as crianças percebessem e identificassem novos atributos dos animais, importantes na formação do conceito de animal desenvolvido no estudo.

Vigotski explica que, neste subtipo, os conceitos podem ser potenciais em relação a dois aspectos: pela referência prática a um determinado círculo de objetos e pelo processo de abstração isoladora que lhe serve de base. O uso desse tipo de conceito está relacionado à possibilidade, algo que ainda pode surgir, e não com o que já está definido.

O subtipo conceitos verdadeiros constitui o último período do desenvolvimento do pensamento infantil. Neste subtipo, é de suma importância o domínio do processo de abstração:

O conceito surge quando uma série de atributos abstraídos torna a sintetizar-se, e quando a síntese abstrata assim obtida se torna forma basilar de pensamento com o qual a criança percebe e toma conhecimento da realidade que a cerca (VIGOTSKI, 2009, p. 226).

Nesse sentido, o emprego da palavra é fundamental na formação do conceito, pois, a partir do seu uso, a criança direciona sua atenção para determinados atributos, sintetiza-os, simboliza-os e opera-os com o conceito abstrato. "A palavra é um signo. Esse signo pode ser usado e aplicado de diferentes maneiras" (VIGOTSKI, 2009, p. 227). A diferença entre o conceito e o complexo reside no fato de que, no primeiro, o emprego funcional é resultante de uma generalização e, no segundo, o modo de aplicação é totalmente diverso.

Vigotski (2009) explica que a generalização de um conceito leva à localização de dado conceito em um determinado sistema de relações de generalidade, que são os vínculos fundamentais mais importantes e mais naturais entre os conceitos. Assim, a generalização significa, ao mesmo tempo, tomada de consciência e a sistematização de conceitos:

A tomada de consciência não surge como um degrau superior e necessário no desenvolvimento a partir de conceitos não conscientizados, mas é trazido de fora. Um modo de agir simplesmente desloca outro. Como a cobra lança fora a pele velha para cobrir-se de outra nova, a criança lança fora e abandona o modo anterior de pensar porque este dá lugar a um novo (VIGOTSKI, 2009, p. 282). 
Neste sentido, a tomada de consciência trazida de fora se refere às atividades práticas e sociais, na qual o uso da palavra é compreendido não como forma de comunicação, mas como organização do pensamento. Os conceitos não conscientizados encontram-se no ambiente social no qual a criança pertence e são assimilados de forma pronta na interação com os adultos que a rodeiam. Vigotski (2009) questiona como a criança em idade escolar toma consciência dos seus próprios conceitos. O autor defende que é justamente na idade escolar que "se intelectualizam e se tornam arbitrárias todas as funções intelectuais básicas” (Idem, p. 283). O desenvolvimento psicológico da criança consiste em mudanças dos vínculos e relações entre as funções interpsíquicas (atividades sociais) e as intrapsíquicas (atividades individuais) e não como uma continuação das funções elementares. A consciência, assim como outras funções psíquicas superiores, desenvolve-se como um processo integral:

[...] modificando a cada nova etapa a sua estrutura e o vínculo entre as partes, e não como uma soma de mudanças particulares que ocorrem no desenvolvimento de cada função em separado. O destino de cada parte funcional no desenvolvimento da consciência depende da mudança do todo e não o contrário (VIGOTSKI, 2009, p. 284).

Para Vigotski, a partir do momento em que os conceitos são psicologicamente concebidos, eles evoluem como significados das palavras. Mas os significados das palavras também evoluem, por exemplo, quando uma criança aprende uma palavra nova referente a um determinado significado, a generalização se inicia de uma forma mais elementar e, posteriormente, desenvolve-se originando generalizações mais complexas, que resultam na formação dos “verdadeiros” conceitos (VIGOTSKI, 2009).

Luria (1994c) destaca que, do ponto de vista da Linguística Moderna, a palavra tem uma estrutura complexa e é composta por dois elementos definidos como a representação material e o significado. A representação material constitui a função representativa da palavra, permite, por meio da linguagem humana, pronunciar uma palavra que pode significar um objeto ou fenômeno ou operar com a palavra mesmo quando o objeto está ausente. O significado da palavra possui uma função mais complexa:

[...] permite analisar os objetos, distinguir nestes as propriedades essenciais e relacioná-los a determinada categoria. Ela é o meio de abstração e generalização, reflete as profundas ligações e relações que os objetos do mundo exterior encobrem (LURIA, 1994c, p. 19). 
A partir de uma análise minuciosa da morfologia da palavra, demonstrou-se a complexidade da função de significado que se constitui em um sistema de códigos que se formou historicamente na humanidade:

Ao dominar a palavra, o homem domina automaticamente um complexo sistema de associações e relações em que um dado objeto se encontra e que se formaram na história multissecular da humanidade. É a essa capacidade de analisar o objeto, distinguir nele as propriedades essenciais e relacioná-lo a determinadas categorias que se chama significado da palavra (LURIA, 1994c, p. 20, grifo do autor).

Como elo dessa relação, encontra-se a palavra como unidade de significação: pensamento e linguagem se constituem mutuamente. Vigotski conclui sobre a importância da palavra na formação de conceito:

Mas, como nos convencemos reiteradas vezes, ao longo de toda nossa investigação, do ponto de vista psicológico o significado da palavra não é senão uma generalização ou conceito. Generalização e significado da palavra são sinônimos. Toda generalização, toda formação de conceitos é o ato mais específico, mais autêntico e mais indiscutível de pensamento. Conseqüentemente, estamos autorizados a considerar o significado da palavra como um fenômeno do pensamento (VIGOTSKI, 2009, p. 398).

Por isso, seria impossível a criança assimilar o conceito de uma forma pronta como supunha a psicologia tradicional. A aplicação da palavra torna-se um meio para o desenvolvimento de funções superiores do pensamento - como a atenção arbitrária, a memória lógica, a discriminação, a comparação e, principalmente, a abstração - que são funções necessárias no processo complexo de formação de conceitos.

Para Vigotski (2009, p. 246), o conceito é simplesmente um ato de generalização, "um ato real e complexo do pensamento que não pode ser apreendido por meio de simples memorização, só podendo ser realizado quando o próprio desenvolvimento mental da criança já houver atingido o seu nível mais elevado”. O complexo processo de formação de conceitos surge como algo novo no pensamento infantil e "projeta o seu desenvolvimento intelectual a um nível cada vez mais elevado" (Idem, p. 384).

Neste trabalho, utilizaremos a definição de conceito com base na concepção teórica que preconiza os conceitos não como entidades isoladas, mas que estão relacionados e organizados em algum tipo de "estrutura" e por considerar que essa definição seja aproximada dos pressupostos da teoria do desenvolvimento histórico- 
cultural. Sendo assim, o conceito é um ato de generalização, constituído de atributos específicos, podendo estar inter-relacionados a outros conceitos e sujeitos a modificações, tanto de significado quanto de sentido, resultante da produção histórica e cultural de conhecimento.

\subsection{Aprendizagem conceitual, mediação pedagógica e papel do professor}

O desenvolvimento humano na teoria histórico-cultural pressupõe a relevância do contexto social na interação com o ser biológico, que inaugura novas formas de comportamento e ativa uma série de funções psíquicas superiores. Os processos de aprendizagem humana estão ligados ao desenvolvimento das FPS. Para Vigotski, "a aprendizagem humana é um fenômeno cultural, historicamente condicionado pelas condições concretas de vida e, por isso mesmo, com enorme amplitude de variação em suas formas de manifestação" (VYGOTSKY, 1997 apud TUNES et al, 2006, p. 116). A aprendizagem humana inicia-se na infância, antes de a criança ingressar na escola.

Nessa perspectiva, Vigotski agrupou as principais teorias sobre a relação entre a aprendizagem e o desenvolvimento da criança em três categorias: a primeira categoria considera a aprendizagem e o desenvolvimento como processos interdependentes, a aprendizagem utiliza o produto ou a consequência do desenvolvimento; a segunda categoria considera que a aprendizagem é desenvolvimento, os dois processos se desenvolvem paralelamente, sendo cada etapa da aprendizagem correspondente a uma etapa do desenvolvimento; e a terceira considera que o desenvolvimento segue a aprendizagem (VIGOTSKII, 1994; VIGOTSKI, 2009).

Em contrapartida, o autor rejeita todas as categorias apresentadas anteriormente e ressalta que a aprendizagem impulsiona o desenvolvimento, ativando uma série de processos desempenhados pelas FPS. Neste sentido, a aprendizagem é "um momento intrinsecamente necessário e universal para que se desenvolvam na criança essas características humanas não-naturais, mas formadas historicamente" (VIGOTSKII, 1994, p. 115).

Diante dessa questão central sobre a aprendizagem, o autor apresenta dois problemas considerados complexos: como ocorre de uma maneira geral a relação entre aprendizagem e desenvolvimento e, ainda, quais seriam as características específicas desta inter-relação, particularmente, na idade escolar. Vigotski admite iniciar o segundo problema para esclarecer o primeiro, e os resultados de investigações realizadas pelo autor permitiram o desenvolvimento do conceito de zona (área) de desenvolvimento proximal. Este conceito presume que "a aprendizagem deve ser coerente com o nível de 
desenvolvimento da criança" e que "[...] existe uma relação entre determinado nível de desenvolvimento e a capacidade potencial de aprendizagem" (VIGOTSKY, 1991, p. 4142).

Como consequência dessa estreita relação entre a capacidade potencial de aprendizagem e o desenvolvimento humano, o processo não poderia limitar-se a um único nível de desenvolvimento. Com isso, foi preciso estabelecer dois níveis de desenvolvimento da criança em função do nível de desenvolvimento e a capacidade potencial que se manifesta a partir da aprendizagem para encontrar a relação entre aprendizagem e desenvolvimento para cada caso específico. O nível de desenvolvimento atual (ou efetivo) é resultante de um processo específico de desenvolvimento já realizado e o nível de desenvolvimento potencial corresponde aos processos de desenvolvimento que ainda estão "amadurecendo", nível em que a criança realiza uma tarefa ou uma atividade com o auxílio dos adultos (maximiza a capacidade da criança de realizar a tarefa ou a atividade específica). Portanto, o nível de desenvolvimento proximal pode ser determinado pela diferença entre o nível atual e o potencial da criança.

A expressão zona de desenvolvimento proximal, amplamente disseminada na área de educação, é decorrente de uma falha na tradução do idioma inglês para o português, devido ao afastamento do original, em russo. O conceito vigotskiano de zona de desenvolvimento proximal seria aquilo que a criança consegue fazer com a colaboração de um adulto. Vale ressaltar que essa colaboração, por exemplo, do professor, não é a resposta para o aluno e, sim, uma "dica" ou um conceito fornecido pelo adulto para que o aluno compreenda o problema ou a questão proposta e consiga resolver a situação colocada. Prestes (2010) defende que a melhor tradução para o termo seria zona de desenvolvimento iminente, pois uma das principais características dessa zona seriam as possibilidades de desenvolvimento, não somente como consequência das atividades escolares, mas de outras atividades como os jogos e as brincadeiras. Neste trabalho, será adotado o termo zona de desenvolvimento iminente, conforme os estudos realizados por Prestes (2010).

Vigotskii (1994, p. 112) explica que, com o estabelecimento desses dois níveis, é possível mensurar os processos atuais de desenvolvimento (aqueles que já foram produzidos), assim como os processos de maturação que ainda estão ocorrendo (aqueles que estão amadurecendo) e pontua sobre a importância da aprendizagem para o desenvolvimento dos processos internos, ou seja, as FPS: 
A aprendizagem escolar orienta e estimula processos internos de desenvolvimento. A tarefa real de uma análise do processo educativo consiste em descobrir o aparecimento e o desaparecimento dessas linhas internas de desenvolvimento no momento em que se verificam, durante a aprendizagem escolar. [...] Esta hipótese pressupõe necessariamente que o processo de desenvolvimento não coincide com o da aprendizagem, o processo de desenvolvimento segue o da aprendizagem que cria a área de desenvolvimento potencial (VIGOTSKII, 1994, p. 116, grifo nosso).

Nesse sentido, o papel da instrução formal (escola) seria desencadear o processo de desenvolvimento de uma série de funções psíquicas superiores, que se encontra em fase de amadurecimento, por meio da aprendizagem, considerada pelo autor como eficiente quando se encontra à frente do desenvolvimento (VIGOTSKI, 2009). Para o autor, o único bom ensino é o que se adianta ao desenvolvimento.

Ainda sobre a relação entre desenvolvimento e aprendizagem, Kostiuk (1991) complementa:

[...] conduzir o desenvolvimento através da educação significa organizar esta interacção, dirigir a actividade da criança para o conhecimento da realidade e para o domínio - por meio da palavra do saber e da cultura da humanidade, desenvolver concepções sociais, convicções e normas de comportamento moral (KOSTIUK, 1991, p. $52)$.

Este autor reitera que as crianças em idade escolar participam de várias atividades educativas e os resultados de investigações realizadas por ele demonstram, por exemplo, que as aquisições de leitura ou escrita pelas crianças "não devem ser consideradas como simples aquisição, mas sim como um aperfeiçoamento da actividade cognoscitiva” (KOSTIUK, 1991, p. 54). As formas de atividade são elaboradas no decorrer do processo de assimilação da experiência social e a passagem da assimilação para o desenvolvimento é um processo complexo. Kostiuk (1991) considera três momentos dessa passagem:

a) o processo pelo qual de facto as crianças conseguem dominar conhecimentos, capacidades ou hábitos específicos [...] passa através de uma série de etapas cujo caráter depende da complexidade do conteúdo que tem de ser dominado, e da receptividade do estudante;

b) o domínio de um material perfeitamente determinado não leva sempre e imediatamente a um progresso no desenvolvimento mental do aluno, ao aparecimento de novas características qualitativas, ou seja, a um desenvolvimento real. Tudo isto depende do que se adquire e de como se adquire. Entram aqui em jogo as características individuais dos alunos, ou seja, as características da actividade nervosa superior; 
c) a passagem da aquisição ao desenvolvimento dá-se de diferentes modos, segundo os diversos aspectos do processo de desenvolvimento. Deve ter-se presente que existem, no desenvolvimento, aspectos diferentes, ainda que ligados: desenvolvimento do conhecimento, da actividade cognoscitiva, desenvolvimento das qualidades mentais (simples e compostas, particulares e gerais) que entram neste processo, e das propriedades funcionais do cérebro que subexistem nelas (KOSTIUK, 1991, 56-57).

Sobre este último ponto supracitado, vale ressaltar que Vigotski já havia estabelecido os diferentes modos para que ocorra a aprendizagem, como apresentado anteriormente. Vigotskii (1994, p. 109, grifo do autor) reitera que “[...] a aprendizagem da criança começa muito antes da aprendizagem escolar. A aprendizagem escolar nunca parte do zero. Toda a aprendizagem da criança na escola tem uma pré-história”.

No caso da aprendizagem escolar, Tunes et al (2006, p. 117) destacam que é frequente encontrar a expressão "aprendizagem escolar" para denominar ou caracterizar a aprendizagem que ocorre no contexto da escola, e ainda "como se fosse de tipo único ou homogênea". As autoras salientam que a escola, como instituição, produz diferentes tipos de aprendizagem considerando o "fato em si, quanto aos mecanismos ou sua repercussão e desdobramentos" (Idem, p. 117).

Sobre a aprendizagem conceitual, Tunes et al (2006, p. 117) ressaltam que este tipo de aprendizagem é intrínseca à instituição escolar em função de transmitir a cultura elaborada pela humanidade que visa ao sistema de conceitos científicos e "constitui de fato, os aspectos medulares dos currículos escolares e das disciplinas que o integram".

Ferreira (2009, p. 25) compartilha da mesma posição quanto aos conhecimentos socialmente produzidos pela humanidade e expressa que, sem o domínio dos conceitos, “torna-se difícil ou quase impossível apreender os princípios e as leis constitutivas do arcabouço teórico explicativo dos fenômenos que integram o universo e de avançar no processo de entendê-lo e agir para transformá-lo". Para a autora, a aprendizagem conceitual constitui-se em uma atividade constante de "(re) elaboração de significação de fenômenos que surgem no espaço/tempo e implica os significados atribuídos e os processos e procedimentos cognitivos implícitos nessa atividade" (FERREIRA, 2009, p.91).

Em relação à aprendizagem conceitual, Vigotski (2009) reitera o papel relevante que esta tem sobre o desenvolvimento do pensamento científico (abstrato ou conceitual) no desenvolvimento da criança em idade escolar sob as condições de ensino em que os conhecimentos estabelecidos historicamente são transmitidos dentro de um sistema. A hipótese levantada pelo autor sobre o desenvolvimento dos conceitos científicos 
apresenta-se "nas condições de um sistema organizado" e os conceitos cotidianos (espontâneos) estão fora de um sistema de conhecimento, porém a relação que envolve esses dois conceitos constitui uma preliminar no desenvolvimento.

[...] deve-se ao amadurecimento precoce dos conceitos científicos e o fato de que o nível de desenvolvimento desses conceitos entra na zona de possibilidades imediatas em relação aos conceitos espontâneos, abrindo-lhes caminho e sendo uma espécie de propedêutica do seu desenvolvimento (VIGOTSKI, 2009, p. 244).

O desenvolvimento de conceitos científicos envolve uma série de FPS, como a memória lógica, a atenção arbitrária, a abstração, a comparação e a discriminação. Estes processos são complexos e, por isso, eles não podem ser memorizados ou assimilados pelo aluno em idade escolar. As condições de ensino, ou seja, os processos educacionais de ensino-aprendizagem relacionados ao desenvolvimento, constituem novo direcionamento e orientação dos processos de formação de conceitos.

$\mathrm{Na}$ teoria histórico-cultural, o conceito é o significado da palavra. Vigotski enunciou a lei geral do desenvolvimento do significado das palavras:

[...] o caminho entre o primeiro momento em que a criança trava conhecimento com o novo conceito e o momento em que a palavra e o conceito se tornam propriedade da criança é um processo psicológico interior, que envolve a compreensão da nova palavra que se desenvolve gradualmente a partir de uma noção vaga, a sua aplicação propriamente dita pela criança e sua efetiva assimilação apenas como elo conclusivo (VIGOTSKI, 2009, p. 250).

Sendo assim, o processo de formação de conceito se inicia no momento em que a criança tem o primeiro contato com a palavra e que os significados desta evoluem até atingir a conceptualização, ou seja, os verdadeiros conceitos. A palavra é um signo verbal e, como signo, "constitui um meio da atividade interna dirigida para o controle do próprio indivíduo" (VIGOTSKI, 2008, p. 52-55). Nesse sentido, as palavras, como signos, orientam internamente o comportamento humano.

Os signos são meios auxiliares utilizados como um "instrumento da atividade psicológica" (VIGOTSKI, 2008, p. 52). As atividades diretas passam a ser atividades mediadas pelo uso de signos que modificam o comportamento do ser humano.

O uso de meios artificiais - a transição para a atividade mediada muda, fundamentalmente, todas as operações psicológicas, assim como o uso de instrumentos amplia de forma ilimitada a gama de atividades em cujo interior as novas funções psicológicas podem operar. Nesse contexto, podemos usar o termo função psicológica 
superior, ou comportamento superior com referência à combinação entre o instrumento e o signo na atividade psicológica (VIGOTSKI, 2008 , p. 56, grifo do autor).

As funções psicológicas superiores se constituem em situações de cunho cultural e social, mediadas pelos signos, por meio do processo de internalização. Este processo consiste na passagem da atividade mediada (externa) para uma atividade interna (psicológica). Para Vigotski (2008, p. 58), “a internalização das atividades socialmente enraizadas e historicamente desenvolvidas constitui o aspecto característico da psicologia humana”. O autor destaca três transformações que ocorrem no processo de internalização: a reconstrução interna de uma operação externa; o processo interpessoal (em nível social), que é transformado em um processo intrapessoal (em nível individual); e esta transformação é resultado de uma série de eventos que ocorrem ao longo do desenvolvimento (VIGOTSKI, 2008).

Como exemplo, pode-se citar a memória natural que passa a ser um tipo de atividade superior quando utiliza os signos como meios auxiliares e o homem passa a dominá-la (memória mnemônica). Por exemplo, os quipus ${ }^{72}$ são recursos auxiliares de memória (natural) que passam ao controle de operações voluntárias de memória (artificial) mediada pelos signos. Vygotsky e Luria (1996) explicam o aperfeiçoamento da memória natural:

\begin{abstract}
A memória se aperfeiçoa à medida que se desenvolvem sistemas de escrita - sistema de signos e de modos de usá-los. O que se aperfeiçoou na Idade Antiga e na Idade Média foi chamado de memória technica ou memória artificial. O desenvolvimento histórico da memória humana pode ser resumido, básica e primordialmente, como o desenvolvimento e o aperfeiçoamento daqueles meios auxiliares que os humanos sociais elaboraram no processo de sua vida cultural (VYGOTSKY; LURIA, 1996, p. 117-118, grifo do autor).
\end{abstract}

Os resultados dos experimentos sobre a memória mediada realizados por Vigotski e seus colaboradores demonstraram que as crianças e também os adultos recorrem à memória técnica (mnemotécnica) e, no decorrer dos experimentos, empregam os meios externos e passam, posteriormente, aos meios internos de atividade de memorização. Um experimento com o intuito de avaliar a memorização natural de uma série de "cifras" com crianças de tenra idade demonstrou que elas não conseguem memorizar por retenção direta (memória natural) e a memorização é possibilitada pelo

\footnotetext{
72 De acordo com a linguagem peruana, os quipus são cordões com nós utilizados para contar mortos, para calcular, para enviar mensagens, por povos primitivos no antigo Peru, na China e no Japão (VYGOTSKY; LURIA, 1996, p. 115).
} 
uso do ábaco ${ }^{73}$, modificando as operações internas. Portanto, “a utilização do ábaco para reter a fila numérica combina procedimentos naturais e artificiais de memorização" (VYGOTSKY, 1997, p. 182).

A partir do exemplo citado acima sobre memória mediada, Oliveira (1997, p. 26) destaca que, em termos genéricos, o conceito de mediação é definido como "o processo de intervenção de um elemento intermediário numa relação; a relação deixa, então, de ser direta e passa a ser mediada por esse elemento". Na teoria histórico-cultural, o conceito de mediação tem como base os postulados do materialismo dialético, que abrange a ideia da relação homem-mundo por meio do trabalho (uso de instrumentos), ampliado por Vigotski para a relação homem-mundo mediada pelo uso de signos. O homem, na qualidade de sujeito de conhecimento, interage com o ambiente por meio de sistemas simbólicos que representam a realidade. Por isso, a linguagem confere ao sistema papel de destaque em função da interposição que se estabelece entre o sujeito e o objeto de conhecimento (REGO, 1995).

A linguagem, na mediação do conhecimento produzido social e historicamente, desempenha o papel de canal de comunicação e a interação entre os sujeitos de conhecimento. A palavra enquanto signo implica uma mediação semiótica realizada por meio da linguagem, ou seja, por meio da fala humana e com base nas relações dialógicas que se estabelecem no ambiente cultural e social.

Para Wertsch et al (1998), a ação humana, externa ou interna, é o foco da abordagem sociocultural. Os autores adotaram o termo sociocultural por considerar ser mais específico e adequado. Nesta abordagem, a análise da mediação da ação humana ocorre por meio de elementos denominados meios mediacionais ou ferramentas culturais que "fornecem, por um lado, a ligação ou a ponte entre as ações concretas conduzidas por indivíduos e grupos, e por outro, contextos culturais, institucionais e históricos, por outro" (Idem, p. 28).

Na obra, Estudos Socioculturais da Mente, Wertsch et al (1998, p. 28) destacam que a mediação é um processo de natureza dinâmica, porém o uso das ferramentas culturais (ou artefatos) modelam a ação, sem determiná-la, e "elas só podem ter um impacto somente quando os indivíduos as usam". Nesse sentido, a mediação é compreendida pelos autores como "um processo envolvendo o potencial das

\footnotetext{
${ }^{73}$ Segundo o Houaiss (2009), o ábaco é um "quadro que permite representar e operar os números por meio das configurações de argolas que deslizam em hastes fixas".
} 
ferramentas culturais para modelar a ação, por um lado, e o único uso dessas ferramentas, por outro" (Idem, p. 29).

O segundo aspecto levantado pelos autores é que "a introdução de uma nova ferramenta cultural nesse processo dinâmico inevitavelmente o transforma" (WERTSCH et al, 1998, p. 29). Wertsch (1998, p. 62) considera que a ação mediada por Vigotski é interpretada como "uma tensão irredutível entre os meios mediacionais e os indivíduos que empregam esses meios". $\mathrm{Na}$ abordagem sociocultural, o indivíduo não age sozinho como agentes, ele é o "indivíduo-que-opera-com-meios mediacionais", ou seja, a introdução de uma ferramenta cultural transforma a ação do indivíduo fornece os meios para que possa ser explorada a "relação entre o funcionamento mental e os contextos institucionais, históricos e culturais nos quais ela ocorre" (Idem, p.62).

O terceiro aspecto sobre a mediação "é que ela sempre envolve a limitação como também o fortalecimento" (WERTSCH et al, 1998, p. 30). O fortalecimento abre novos campos de ação mediada, também é importante ter em mente que qualquer forma de mediação envolve alguma forma de limitação ${ }^{74}$.

E, por último, o quarto aspecto refere-se às ferramentas culturais que surgem por razões diversas "que não a de facilitar muitos dos tipos de ações que elas acabam delineando de fato" (Idem, p. 31).

[...] as ferramentas culturais foram selecionadas, ou até mesmo impostas por outras forças socioculturais, e quaisquer benefícios que elas por ventura originaram para a participação orientada ou para a apropriação participatória foram mais ou menos acidentais ou não previstos. Esses efeitos acidentais ou não previstos são o que pode-se chamar subprodutos (WERTSCH et al, 1998, p. 32, grifo nosso).

Para esses autores, as ferramentas culturais ou os meios mediacionais não foram especificados para promover a participação orientada ou a apropriação participatória ${ }^{75}$, nesse sentido, elas podem ter sido selecionadas ou impostas, resultando em subprodutos, considerados como efeitos acidentais ou não previstos. Na abordagem sociocultural, a mediação ocorre por meio da ação mediada, que utiliza as ferramentas culturais dentro de contextos históricos, institucionais e culturais. Os autores ainda

\footnotetext{
${ }^{74}$ Para os autores, "um dos pontos que continua inexplicável na visão da ação mediada [...] é que mesmo se uma nova ferramenta cultural nos liberta de alguma limitação anterior de perspectiva, ela introduz suas próprias limitações" (WERTSCH et al, 1998, p. 31).

${ }^{75}$ Rogoff (1998, p. 125) define o conceito de participação guiada (ou orientada) "aos processos e sistemas de envolvimento entre as pessoas à medida que elas se comunicam e coordenam esforços ao participar de atividades de cunho cultural", a apropriação participatória refere-se "ao processo pelo qual os indivíduos transformam seus entendimentos sobre e a responsabilidade para com as atividades de suas participações" (p. 132).
} 
destacam que o uso incorreto dessas ferramentas pode resultar em ações "que não sejam úteis ou até mesmo sejam antíteses as nossas intenções e afirmações expressas quanto à elaboração das ferramentas que empregamos" (WERTSCH et al, 1998, p. 33).

Portanto, a mediação pode ocorrer tanto pelo uso de instrumentos ou signos (mediação semiótica) quanto por meio da interação social. Destaca-se aqui a mediação que ocorre em situação escolar, podendo denominar-se mediação pedagógica.

\subsubsection{A mediação pedagógica e o papel do professor}

A expressão mediação pedagógica pode ser atribuída à relação professor-aluno na elaboração de conhecimentos no processo de ensino-aprendizagem. Em suas pesquisas, Vigotski não desenvolveu especificamente o conceito de mediação pedagógica, mas da aprendizagem resultante da mediação semiótica, como ocorre nas situações escolares. Como já assinalado nesse texto, "o bom ensino é o que se adianta ao desenvolvimento". Esse desenvolvimento somente é possível a partir da interação social em que os diferentes significados e sentidos são atribuídos aos objetos de conhecimento, compartilhados nas relações mediadas entre o sujeito cognoscente e o objeto a ser conhecido e, ainda, entre os próprios sujeitos.

Por isso, a mediação por meio da linguagem é relevante no desenvolvimento do pensamento conceitual e se constitui na interação social, na relação com o outro. É essa relação que permite a criança assimilar palavras do discurso do adulto, mas também ressignificar e elaborar os seus próprios conceitos. Sobre esse aspecto, Fontana (1996) destaca a importância do outro nas operações intelectuais no processo de formação de conceitos:

\footnotetext{
A mediação do outro desperta na mente da criança um sistema de processos complexos de compreensão ativa e responsiva, sujeitos às experiências e habilidades que ela já domina. Mesmo que ela não elabore ou não apreenda conceitualmente a palavra do adulto, é na margem dessas palavras que passa a organizar seu processo de elaboração mental, seja para assumi-las ou para recusá-las (FONTANA, 1996, p. 19).
}

O sistema complexo de formação de conceitos surge na mediação que se efetiva na relação com outrem por meio da palavra, processo que se inicia nas generalizações mais simples às mais elaboradas, até atingir a conceptualização. Em suas pesquisas sobre a elaboração conceitual da criança na escola, a autora considerou como mediação pedagógica o "espaço próprio do professor na relação de ensino" (FONTANA, 1996, p.32). 
Tunes, Tacca e Bartholo Jr. (2005, p. 695), com base na lei de geral de desenvolvimento psíquico concebida por Vigotski, destacam que "é na situação interpsicológica que brota o significado da relação pedagógica. Estão aí circunscritas, a um espaço relacional, as ações do professor e do aluno". Ao examinarem o conceito de mediação, esses autores evidenciam a confusão e a imparcialidade na compreensão do papel do professor na teoria histórico-cultural e ressaltam que o desenvolvimento psicológico ocorre como resultado dessa relação.

\begin{abstract}
Ainda que seja possível admitir-se o professor como mediador do conhecimento para o aluno, isso não esgotaria sua função, nem daria conta do que lhe é primordial. O professor é uma pessoa vulnerável à alteridade do aluno. Assim, trabalho pedagógico e zona de desenvolvimento proximal não significam outra coisa que não ação conjunta. O desenvolvimento psicológico é resultado de algo que acontece no espaço da relação professor e aluno, como possibilidade de realização futura (TUNES; TACCA; BARTHOLO Jr., 2005, p. 695).
\end{abstract}

A ação conjunta estabelecida nas situações escolares possibilitará o desenvolvimento psicológico do aluno, por meio da perspicácia do professor em identificar as necessidades do aluno diante de seu aprendizado, por meio do comportamento e das diferentes relações sociais no ambiente escolar (interação alunoprofessor e aluno-aluno). Os autores concluem que "são necessárias parcerias nos espaços pedagógicos para que haja a possibilidade de empreendimento de novas situações sociais de desenvolvimento" (TUNES; TACCA; BARTHOLO Jr, 2005, p. 696).

Com base em autores como Fontana (1996) e Tunes, Tacca e Bartholo Jr. (2005), optou-se por utilizar a expressão mediação pedagógica no presente estudo como a mediação que ocorre nos processos educacionais, especificamente em sala de aula, caracterizada pela função mediadora da palavra como signo linguístico por meio da linguagem e das inter-relações sociais estabelecidas no ambiente escolar, principalmente a mediação realizada pelo professor com intencionalidade pedagógica, que permita acompanhar o processo de pensamento do aluno e, a partir disso, encontrar as estratégias adequadas para a interposição entre o conhecimento e o aluno.

Ferreira (2009) assinala que, na mediação dos processos de ensino, vão se formando os conceitos científicos e estes devem ser flexíveis e móveis como os primeiros: 
[...] como os conceitos científicos expressam o movimento real, eles são igualmente móveis e flexíveis como os fenômenos por eles significados, os que lhe conferem um caráter histórico. Assim devem ser flexíveis e móveis os conceitos que os alunos vão formando, como também o processo de ensino que medeia a sua formação (FERREIRA, p. 157, grifo nosso).

Nesse sentido, o processo de formação de conceitos pode ser flexível de acordo com os processos educacionais, devido ao movimento tanto em relação aos conceitos cotidianos e científicos quanto aos processos utilizados na elaboração conceitual realizada pelos alunos. Vigotski (2009) explica que esse movimento - o curso de desenvolvimento dos conceitos científicos - ocorre no processo educacional, sendo a participação do professor de fundamental importância no desenvolvimento intelectual da criança:

O curso de desenvolvimento do conceito científico nas ciências sociais transcorre sob as condições do processo educacional, que constitui uma forma original de colaboração sistemática entre o pedagogo e a criança, colaboração essa em cujo processo ocorre o amadurecimento das funções psicológicas superiores da criança com o auxílio e a participação do adulto (VIGOTSKI, 2009, p. 244).

A colaboração sistemática entre o professor (pedagogo) e a criança é o meio pelo qual os conceitos científicos são apresentados à criança dentro de um sistema, os conceitos cotidianos estão inter-relacionados aos científicos e o desenvolvimento destes entra na zona de desenvolvimento iminente. A função do professor seria atuar nessa zona e consequentemente desenvolver o intelecto da criança.

Vigotski (1988, p. 108) define intelecto como "a soma de muitas capacidades diferentes (observação, atenção, memória), mas que cada uma independe da outra e são desenvolvidas mediante exercício adequado”. Nesse sentido, para o autor, o papel do professor em relação ao desenvolvimento do intelecto consistiria em "desenvolver não uma única capacidade de pensar, mas muitas capacidades particulares de pensar em campos diferentes" (VIGOTSKY, 1991, p. 38).

Em suas argumentações, Vigotski teve como intuito elaborar um status científico referente ao papel do professor no processo pedagógico para subsidiar os cursos ministrados por ele na Escola de Formação de Professores, em Gomel, Bielorrússia. Em sua obra Psicologia pedagógica, Vigotski dedica um capítulo à psicologia e ao professor, em que apresenta uma explanação sobre a natureza psicológica do trabalho docente. A partir das relações estabelecidas entre a aprendizagem e o desenvolvimento, o papel desempenhado pelo professor muda completamente, "ele tem de se transformar 
em organizador do ambiente social, que é o único fator educativo" (VIGOTSKI, 2003, p. 296).

Entretanto, na literatura atual, é muito comum a ocorrência e o uso da expressão professor mediador para representar o papel do docente na orientação teóricometodológica nos processos educacionais. Andrada (2009, p. 105) compartilha da mesma ideia ao questionar a representação ${ }^{76}$ do papel do professor na perspectiva vigotskiana expressa na figura do professor mediador, "tal interpretação nos inquieta, dentre outros aspectos, por se colocar em uma perspectiva que reforçaria a ideia do professor como mero transmissor de conteúdos, aspecto criticado por Vigotski”.

O uso da expressão professor como mediador também é apresentada na proposta curricular da Educação Básica da SEE-DF:

O desenvolvimento dos estudantes é favorecido quando vivenciam situações que os colocam como protagonistas do processo ensinoaprendizagem, tendo o professor como mediador do conhecimento historicamente acumulado, por meio de ações intencionais didaticamente organizadas para a formação de um sujeito histórico e social (DISTRITO FEDERAL, 2014a, p. 33, grifo nosso).

De acordo com esse pressuposto teórico da proposta curricular em questão, o papel do professor é organizar os conteúdos e as estratégias pedagógicas por meio da aprendizagem que se realiza nas interações dialógicas (sociais), para que ele possa atuar na zona de desenvolvimento iminente e impulsionar o desenvolvimento intelectual dos estudantes. Apesar de os pressupostos apresentarem a expressão professor como mediador, a função de organizador das atividades condiz com os postulados elaborados por Vigotski quanto ao papel desempenhado pelo professor. Tacca (2006, p. 48) destaca que, para o real entendimento do conceito de zona de desenvolvimento iminente proposto por Vigotski, o termo estratégia pedagógica deve ser compreendido "em uma outra perspectiva, ela se orienta para a relação social que passa a ser uma condição para a aprendizagem, pois só ela dá possibilidade de conhecer o pensar do outro e interferir nele”. A atuação do professor nessa zona possibilita criar novas situações de ensinoaprendizagem na elaboração do conhecimento. Segundo a autora,

Nessa perspectiva, estamos dando um entendimento às estratégias pedagógicas da aprendizagem àqueles procedimentos que implicam uma relação pedagógica cujo objetivo não é manter o aluno ativo apenas, mas captar sua motivação, suas emoções, para, a partir daí, colocar o seu pensamento na conjunção de novas aprendizagens (TACCA, 2006, p. 49).

\footnotetext{
${ }^{76}$ No sentido da imagem ou da ideia concebida do papel do professor.
} 
Ao ressaltar a importância da interação entre o professor e o aluno, Tacca postula que o professor deve executar, de forma reflexiva, a sua prática pedagógica e a sua relação com o aluno no processo de ensino-aprendizagem para atingir o objetivo maior da educação que, nas palavras da autora, é a promoção do “desenvolvimento humano no contexto social em que vivemos" (Idem, p.67).

$\mathrm{Na}$ aprendizagem conceitual, o processo de formação de conceito é complexo, configurado pelas primeiras generalizações até chegar à conceptualização, os conceitos não são assimilados de forma pronta pela criança como supunha a psicologia tradicional. Vigotski (2009) recusa o ensino de conceitos pelo método direto (assimilação de conceitos) e explica o motivo de ele ser "pedagogicamente estéril", assim como as consequências para a criança quando o professor adota este tipo de método:

O professor que envereda por esse caminho costuma não conseguir
senão uma assimilação vazia de palavras, um verbalismo puro e
simples que estimula e imita a existência dos respectivos conceitos na
criança mas, na prática, esconde o vazio. Em tais casos, a criança não
assimila o conceito mas a palavra, capta mais de memória que de
pensamento e sente-se impotente diante de qualquer tentativa de
emprego consciente do conhecimento assimilado. No fundo, esse
método de ensino de conceitos é a falha principal do rejeitado método
puramente escolástico de ensino, que substitui a apreensão do
conhecimento vivo pela apreensão de esquemas verbais mortos e
vazios (VIGOTSKI, 2009, p. 247).

A atuação do professor nesse processo de elaboração de conceito torna-se indispensável para propor diferentes situações didáticas, realizando a mediação pedagógica para permitir diferentes generalizações para chegar à abstração em que a criança apreenda e utilize o conceito de forma consciente. Nessa perspectiva, Ferreira (2009), em suas pesquisas sobre o processo de elaboração conceitual de casa, ressalta que a passagem da generalização para a abstração é uma etapa difícil:

[...] ao desencadear o processo de elaboração do conceito de "casa", por exemplo, as crianças podem observar diferentes tipos de casa, no caminho para a escola, em fotografias, gravuras, filmes, etc. Porém, casa geral é uma abstração. Essa passagem é uma etapa difícil que exige uma mediação eficaz para o processo de generalização efetivarse adequadamente. Caso contrário, poderá confundir-se conceituação com memorização (FERREIRA, 2009, p. 150). 
Por isso, a mediação pedagógica efetiva revela-se importante no processo de elaboração de conceito para que se desenvolvam as FPS, como, por exemplo, a abstração. Ferreira (2009) destaca o papel do professor na mediação pedagógica:

[...] o professor desempenha uma função singular, pois o êxito depende, em grande parte, da sua competência para mediá-lo. Entre essas competências, merecem destaque o domínio dos conceitos científicos das diferentes áreas do conhecimento que compõem o currículo escolar; das peculiaridades da elaboração conceitual (fatores sociocognitivos e afetivos); das condições pedagógicas inerentes à formação e ao desenvolvimento de conceitos em contextos escolares (FERREIRA, 2009, p. 96).

Assim como Tacca (2006), Ferreira (2009) destaca que o papel do professor abrange diversos domínios das circunstâncias pedagógicas, que englobam desde aspectos afetivos até os conteúdos formais. Em suma, o professor detém os meios (ou as formas) para conduzir a criança ao processo de elaboração conceitual em situações formais de ensino e confrontá-las com o conhecimento adquirido das experiências sociais (pessoais e culturais) na realização da mediação pedagógica.

Pelo que já foi exposto até aqui, os pressupostos da teoria de desenvolvimento histórico-cultural de Vigotski podem contribuir nas orientações didático-pedagógicas para que os professores, organizadores do ambiente escolar, possam criar ou promover momentos de aprendizagem qualitativos e, consequentemente, desenvolvam o aluno de uma forma integral, tanto intelectualmente quanto socialmente.

Nessa perspectiva, a escolha do referencial teórico justifica-se por explicitar que é na relação social que o homem se constitui em um ser histórico e social, enaltece seu pensamento e desenvolvem as funções psíquicas superiores. Sendo assim, a formação de conceito, por ser um processo complexo, envolve as diversas relações sociais estabelecidas e as experiências vivenciadas (formais ou informais) pelas crianças e adultos (responsáveis ou professores) na busca do conhecimento produzido historicamente pela humanidade, compartilhado e sujeito a constantes modificações ao longo do tempo. 


\title{
CAPÍTULO 4
}

\author{
AS TRAJETÓRIAS ANIMADAS
}

\section{O PERCURSO METODOLÓGICO NA FORMAÇÃO DE CONCEITO}

\begin{abstract}
[...] no momento em que a criança toma conhecimento pela primeira vez do significado de uma nova palavra, o processo de desenvolvimento dos conceitos não termina mas está apenas começando (VIGOTSKI, 2009).
\end{abstract}

\subsection{O conceito}

À luz da teoria histórico-cultural, a formação de conceitos é um dos temas estudado por Vigotski e seus colaboradores e sintetiza algumas das proposições teóricas acerca das funções psíquicas superiores e o processo de desenvolvimento humano. A gênese e a natureza psicológica do conceito cotidiano ${ }^{77}$ e do científico são diferentes, sendo este último originado no processo de aprendizagem formal, ou seja, no contexto educativo.

A relevância dos estudos referentes à formação de conceito como objeto de análise é considerada importante para esclarecer a complexidade do processo de formação de conceitos, as vias de desenvolvimento tanto do conceito cotidiano quanto do científico e a inter-relação entre essas duas linhas de desenvolvimento para compreendermos como as crianças operam tanto no desenvolvimento do conceito cotidiano (pensamento sincrético e por complexos) quanto no científico (pensamento abstrato) e chegam à conceituação.

Após anos de estudos experimentais sobre a "evolução" do pensamento conceitual em crianças em idade escolar, Natadze (1991) concluiu que a maior dificuldade na aprendizagem de conceitos reside no fato de a criança descobrir os aspectos essenciais (atributos) de um conceito e compreender a sua importância.

A partir das análises experimentais, Vigotski (2009, p. 276) postula que a "percepção da semelhança exige a formação de uma generalização primária ou de conceito que abranja os objetos entre os quais existe tal relação". Por isso, a criança em idade escolar percebe

\footnotetext{
${ }^{77}$ Neste trabalho, o termo conceito espontâneo,como é definido na edição brasileira do livro A construção do pensamento e da linguagem, será substituído por conceito cotidiano, por considerar, assim como o autor, ser resultante das experiências cotidianas vivenciadas pela criança.
} 
primeiramente as diferenças e depois, as semelhanças, tendo em vista que a generalização ou a abstração dos atributos de um conceito tornam-se mais complexos.

Além disso, Vigotski (2009) verificou que o emprego funcional da palavra, nos experimentos desenvolvidos, é a parte fundamental do processo de formação de conceito. $\mathrm{O}$ método funcional da dupla estimulação, desenvolvido por Vigotski e seus colaboradores, permitiu observar como as palavras ou os signos-estímulos são introduzidos gradualmente e como o sujeito experimental operou com a palavra durante todo o experimento.

\begin{abstract}
A investigação experimental do processo de formação de conceitos mostrou que o emprego funcional da palavra ou de outro signo como meio de orientação ativa da compreensão, do desmembramento e da discriminação de traços, de sua abstração e síntese é parte fundamental e indispensável de todo o processo. A formação de conceito ou a aquisição de sentido através da palavra é o resultado de uma atividade intensa e complexa (operação com palavra ou signo), da qual todas as funções intelectuais básicas participam em uma combinação original (VIGOTSKI, 2009, p. 168, grifo nosso).
\end{abstract}

O processo de formação de conceito engloba as etapas citadas anteriormente, em que o emprego funcional da palavra ou do signo-estímulo é o meio de formação de conceitos diante de situações colocadas ou a proposição de problemas que possibilita observar o desenvolvimento do pensamento, desde a fase concreta (pensamento sincrético e por complexos) até a fase abstrata (pensamento conceitual) do sujeito experimental. Para Vigotski (2009, p. 170), “o conceito é impossível sem palavras”.

A formação de conceito pressupõe o contato com o objeto a ser conhecido, a distinção dos atributos (traços) até a generalização, seja por meio do emprego da palavra e/ou dos signos-estímulos (instrumentos culturais), seja por meio da interação com o meio social (relações sociais).

Vigotski (2009, p. 246) pontua que o conceito "é um ato real e complexo de pensamento [...] em termos psicológicos, um ato de generalização". Na perspectiva da teoria histórico-cultural, quando ocorre a generalização de um conceito no processo de aprendizagem, esse conceito se localiza dentro de um "sistema de relações de generalidade que são os vínculos fundamentais mais importantes e mais naturais entre os conceitos" (VIGOTSKI, 2009, p. 292). As relações de generalidade permitem a tomada de consciência dos atributos, ou seja, das características que possibilitam a apreensão do conceito.

O ensino e a aprendizagem de conceitos é um processo longo e complexo que vai além da memorização de definições. De acordo com Vigotski (2009), o processo real de formação de conceitos é um movimento de cima para baixo e do geral para o particular. Outros autores, 
como Ferreira (2009), destacam que, nesse movimento ascendente/descendente considerado como uma (re) elaboração conceitual, é necessário pensar em procedimentos didáticos que sejam favoráveis ao processo de formação de conceitos. De acordo com essa autora, as propostas de ensino aprendizagem de conceitos científicos abrangem as seguintes estratégias:

\footnotetext{
* sondagem dos conhecimentos prévios dos alunos;

* questionamento sobre estes conhecimentos;

* introdução de novos conceitos; e

* aplicação dos conceitos em um amplo leque de situações de aprendizagem.
}

Neste sentido, o objetivo desta tese é analisar em que medida os alunos do $5^{\circ}$ ano (Anos Iniciais do Ensino Fundamental) se apropriam das informações científicas apresentadas no desenho animado Меи согро, теи mundo, produzido para fins educativos e como essas informações são articuladas no processo de formação do conceito de ecossistema. A metodologia foi composta por duas etapas: o ensaio metodológico e a nova proposta metodológica.

\subsection{Ensaio Metodológico}

O ensaio metodológico consistiu-se na primeira etapa da metodologia, com o intuito de: avaliar o tema aquecimento global; a série de desenho animado Invasão Plâncton; e, ainda, testar os instrumentos de pesquisa.

A escolha do tema aquecimento global é relevante porque trata da questão ambiental e abrange diferentes áreas do conhecimento, sendo pauta das discussões que ocorrem em nível nacional e mundial para a compreensão do fenômeno da mudança global do clima. Além disso, o tema permite a discussão de diferentes conceitos dentro do componente curricular de Ciências da Natureza, como a temperatura, os gases de efeito estufa (GEE), o equilíbrio dos ecossistemas, as ações antrópicas e a poluição ambiental.

Posteriormente à definição do tema, optou-se pela série de animação Invasão Plâncton, em função de as narrativas dos episódios possibilitarem a discussão dos conceitos e das informações referentes aos diversos fatores relativos à compreensão do tema aquecimento global. De acordo com o sítio ${ }^{78}$ eletrônico de divulgação do desenho animado Invasão Plâncton, essa é a primeira série animada que trata dos assuntos aquecimento global e

\footnotetext{
${ }^{78}$ Disponível em:<http://www.planktoninvasion.com/fr $>$. Acesso em: 15 abr. 2013.
} 
mudanças climáticas. A primeira temporada é composta por quarenta episódios, lançada em 2011, na França, e, em 2012, no Brasil, sendo transmitida pelo canal fechado Cartoon Network. A primeira temporada da série foi comprada, em 2013, pelo Programa TV Escola ${ }^{79}$ do Ministério da Educação. Cada episódio possui, em média, sete minutos e denomina-se operação, que caracteriza a missão a ser executada pelo trio de plânctons, por exemplo: Operação bola amarela que aquece. Ao total, foram exibidos quinze episódios. A figura 22, a seguir, apresenta as principais personagens da série Invasão Plâncton.

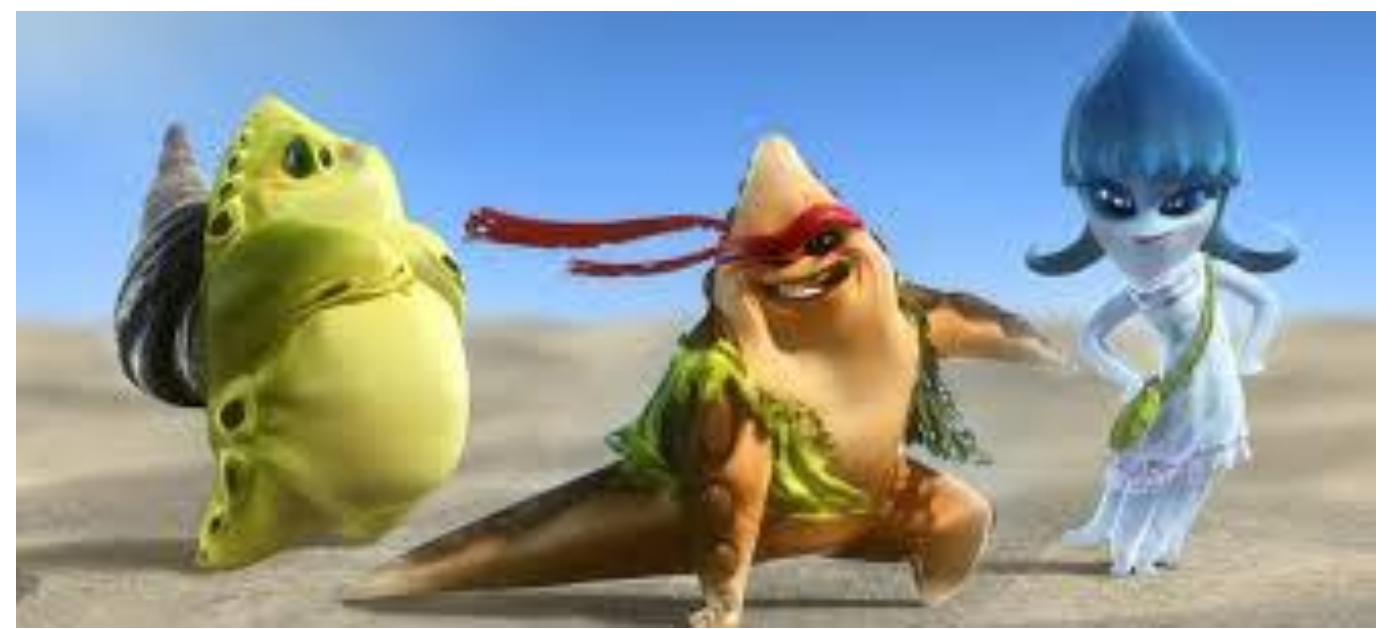

Figura 22. Principais personagens da série Invasão Plâncton. Da esquerda para a direita, Pulpo Calamares, Capitão John C. Star e Ana Medusa, respectivamente. Disponível em:〈http://www.tvbrasil.ebc.com.br〉. Acesso em: 7 jul. 2015.

Para o desenvolvimento do ensaio metodológico, a pesquisa foi realizada em uma instituição pública pertencente à SEE-DF. A primeira visita na escola teve o intuito de explicar a proposta do estudo para a direção da instituição. Na segunda visita, houve uma conversa detalhada com a vice-diretora e com a professora Léia ${ }^{80}$, responsável pelo $5^{\circ}$ ano (turma A) e indicada pela escola. A direção justificou a escolha desta professora em função de sua experiência com o $5^{\circ}$ ano, ainda que ela não seja uma professora pertencente ao quadro efetivo. Após essa breve conversa sobre a pesquisa, a professora se dispôs a colaborar e a participar efetivamente do estudo.

Assim, definida a turma participante da pesquisa, o $5^{\circ}$ ano, turma $\mathrm{A}$, composta por vinte e três alunos, pertencentes à faixa etária entre nove e treze anos de idade. Ao total, treze alunos participaram efetivamente de todas as atividades propostas pela entrevistadora. Essa defasagem ocorreu em virtude da falta dos alunos às aulas, por diversos motivos, durante o

79 O Programa TV Escola do Ministério da Educação compra as séries de desenhos animados, filmes e documentários para fins educativos por meio de licitações públicas.

${ }^{80} \mathrm{O}$ nome da professora é fictício, para preservar a sua identidade. 
desenvolvimento do estudo. Os termos de consentimento livre e esclarecido foram entregues aos alunos para a ciência e a autorização por escrito pelos pais para a participação na pesquisa.

A partir disso, iniciou-se a pesquisa. O ensaio metodológico foi dividido em três etapas. A primeira etapa foi uma entrevista estruturada com a professora responsável pela turma, para conhecer as estratégias de aprendizagem utilizadas e os temas que já haviam sido trabalhados. As demais etapas, segunda e terceira, foram realizadas as atividades com os alunos. A segunda etapa consistiu em quatro atividades: interação, aplicação de questionário, solicitação de desenho e texto ${ }^{81}$ e, por último, a entrevista individual. Estas atividades tiveram como principal objetivo a identificação dos conceitos cotidianos sobre o tema aquecimento global. A terceira etapa consistiu em quatro sessões, sendo a primeira exibida somente um episódio e as demais, compostas por cinco episódios cada. Os episódios foram previamente selecionados e após cada sessão foram desenvolvidas as atividades com os alunos (produção de texto, carta ao amigo e situação-problema) referentes aos episódios exibidos, com o intuito de verificar a compreensão das informações apresentadas na narrativa do desenho animado.

Os $\operatorname{dados}^{82}$ gerados apresentaram definições que foram identificadas tanto nos conhecimentos prévios (pré-exibição) quanto nas atividades da pós-exibição. O excesso de episódios e de informações apresentadas nas narrativas do desenho sem uma orientação didática pode ter confundido os alunos em vez de esclarecer sobre o tema aquecimento global. Assim, não foram oportunizados momentos de discussão com os alunos, durante e após as exibições dos episódios do desenho animado, para esclarecer os objetivos das missões realizadas pelo trio de plânctons e os insucessos das operações em que se esperava a ocorrência do aquecimento global.

A análise dos resultados preliminares desse ensaio metodológico ofereceu inferências de aprendizagem, especialmente no que diz respeito aos atributos do conceito, que poderiam ser discutidos ou explicitados com a colaboração do professor. A aquisição de informações ou a aprendizagem de novos conceitos pode ser limitada quando não ocorre a intervenção pedagógica na qual o papel do professor é importante para que o aluno consiga refletir e organizar o seu pensamento no processo de aprendizagem escolar. O ensaio também nos revelou que as relações são muito mais complexas do que se imaginava.

\footnotetext{
${ }^{81} \mathrm{O}$ desenho e o texto consistem em uma atividade em que a entrevistadora coloca o tema a ser trabalhado no quadro e solicita um desenho sobre o tema em uma folha de papel sulfite. Após a confecção do desenho, a entrevistadora solicita que o aluno explique o seu desenho em forma de texto.

${ }^{82}$ Dados não publicados.
} 
Portanto, os resultados gerados neste ensaio possibilitaram avaliar a metodologia aplicada e forneceram subsídios para a redefinição e o planejamento da metodologia que seria aplicada na tese, ou seja, a nova proposta metodológica.

\subsection{Nova metodologia}

A nova metodologia sofreu alterações a partir da prática dos procedimentos realizados no ensaio metodológico, embora o ano e a etapa de ensino tenham sido mantidos. A primeira mudança foi o tema que, consequentemente, modificou a escolha do desenho animado. Além disso, considerou-se imprescindível a mediação feita pela entrevistadora, que assumiu a função de professora responsável pela turma nas situações de aprendizagem desenvolvidas em sala de aula.

A partir desta constatação, planejaram-se estratégias de investigação que se constituíram em inovações na nova metodologia. Outro resultado esperado foi, ainda, estimular os alunos a participarem das atividades, despertando o interesse deles pelo tema a ser desenvolvido.

\subsubsection{A escolha do tema}

A partir do tema escolhido no ensaio metodológico, aquecimento global, foi possível perceber a importância do conceito de ecossistema. Isso se deve ao fato de o primeiro tema estar intimamente relacionado ao desequilíbrio do ecossistema, pois é um dos fatores que provocam as alterações ambientais.

De acordo com Odum e Barrett (2011), o ecólogo britânico Sir Arthur G. Tansleyfoi um dos primeiros cientistas a cunhar o termo ecossistema, em 1935. Este termo surgiu nas literaturas especializadas em ecologia (europeia, norte-americana e russa) no século XIV. Estes autores apresentam a seguinte definição de ecossistema:

Os organismos vivos (bióticos) e seu ambiente não vivo (abiótico) estão inter-relacionados e interagem uns com os outros. Um sistema ecológico ou ecossistema é qualquer unidade que inclui todos os organismos (a comunidade biótica) em uma dada área interagindo com o ambiente físico de modo que um fluxo de energia leve a estruturas bióticas claramente definidas e à ciclagem de materiais entre componentes vivos e não vivos. É mais que uma unidade geográfica (ou ecorregião): é uma unidade de sistema funcional, com entradas e saídas, e fronteiras que podem ser tanto naturais quanto arbitrárias (ODUM; BARRETT, 2011, p. 18, grifo do autor). 
Para Ricklefs (2010), o ecossistema é formado por um conjunto de organismos vivos e seus ambientes, tanto físico quanto químico. São sistemas complexos que incluem diferentes tipos de organismos que vivem em uma variedade de meios, compondo microambientes que se integram com o ecossistema. $\mathrm{O}$ autor expõe que:

Ao longo de suas vidas, os organismos transformam energia e processam materiais. Para executar isso, os organismos devem adquirir energia e nutrientes dos seus arredores e se livrarem de produtos indesejados de rejeito. Ao fazer isso, modificam as condições do ambiente e os recursos disponíveis para outros organismos, e contribuem para os fluxos de energia e o ciclo de elementos químicos no mundo natural (RICKLEFS, 2010, p. 4).

Para que o aluno apreenda o conceito de ecossistema, ele deve abstrair pelo menos dois atributos do conceito: ser vivo e ser não vivo. A partir da compreensão desses dois conceitos, inclui-se o terceiro atributo, que são as inter-relações entre os seres vivos, não vivos e ambiente. Portanto, os atributos do conceito ecossistema seriam a identificação e a caracterização de seres vivos e não vivos e a relação estabelecida entre eles no ecossistema, que se resumem em relações ecológicas. Neste trabalho, adotou-se o conceito proposto por Odum e Barret (2011).

A escolha do tema ecossistema justifica-se por ser um conceito relevante tanto no ensino de Ciências quanto no ensino de Biologia, assim como em outras áreas do conhecimento, por exemplo, Geografia e Educação Ambiental. Ab'Saber (2009, p. 89) considera o conceito de ecossistema de "alto valor interdisciplinário" pela importância nos diferentes níveis de exposição e detalhamento. Abaixo, seguem algumas assertivas que explicitam tal consideração e os temas distintos que podem ser abrangidos:

i. é a unidade ecológica básica mantenedora do fluxo de energia e do ciclo de materiais;

ii. os seres vivos e não vivos estabelecem relações de interdependência;

iii. as teias alimentares contribuem para o controle das populações das espécies que habitam os ecossistemas;

iv. as espécies endêmicas desempenham um papel no seu habitat e a introdução de espécies exóticas provoca alterações no sistema ecológico;

v. a conservação dos ecossistemas é essencial para a preservação das espécies e para o equilíbrio ecológico do meio ambiente; e

vi. os ecossistemas têm sofrido constantes alterações em função das ações antrópicas decorrentes. 
As assertivas citadas acima visam a contribuir com ações e atitudes a serem discutidas para o desenvolvimento sustentável e a serem praticadas pelas gerações atuais para garantir os recursos naturais para as gerações futuras. De acordo com a pesquisa de Mendonça-Filho e Tomazello (2003) sobre as imagens de ecossistemas em livros didáticos de Ciências e suas implicações para a Educação Ambiental, o conceito de ecossistema "é um dos pilares da educação ambiental, pois exige a noção de ciclagem de recursos com interferência de diferentes agentes, principalmente, a do homem". Após a análise dos dados gerados na sua pesquisa, os autores concluíram que as imagens de ecossistema apresentadas nos livros didáticos manifestam um conceito estereotipado, no qual contém uma grande biodiversidade e, principalmente, em que a harmonia é independente da interferência humana.

Outra autora, como Dias (2013), compartilha da mesma ideia e tece uma crítica ao conceito de ecossistema ser restrito a nível ecológico e por não considerar o homem como um "ser social de modificação da sua relação específica com a natureza". As ações antrópicas como a queima e o uso de combustíveis fósseis, o desmatamento de florestas e a construção civil são alguns exemplos que contribuem para a alteração da dinâmica dos fluxos dos ecossistemas.

As duas posições dos pesquisadores explicitadas anteriormente sinalizam a importância do tema ecossistema, em virtude tanto de concepções equivocadas quanto de um conceito que não sustenta mais o nível de degradação ambiental provocado pelo ser humano ao longo dos anos e, principalmente, as consequências que ocasionam as modificações dos ecossistemas de uma maneira geral.

De acordo com o Currículo em Movimento, especificamente dos Anos Iniciais do Ensino Fundamental, os conteúdos do componente curricular de Ciências da Natureza são organizados por três temáticas, amplas e integradas, sendo elas: ambiente; ser humano e saúde; e recursos tecnológicos. Além disso, os temas "são norteadores na organização curricular de objetivos e conteúdos" (DISTRITO FEDERAL, 2014b, p. 114), que permitem incorporar os eixos transversais (educação para a diversidade, cidadania e educação em e para os direitos humanos, e educação para a sustentabilidade) e integradores (alfabetização, letramento e ludicidade), sendo estes consoantes com as orientações dos Parâmetros Curriculares Nacionais (BRASIL, 1998). O tema ecossistema é introduzido como conteúdo no $5^{\circ}$ ano do Ensino Fundamental.

Conforme Sforni (2004, p. 129), “antes de organizar o ensino de um conceito específico é importante situá-lo no interior do objeto mais geral da área de conhecimento em que se insere". Com base nessa premissa, considerou-se pertinente elaborar um mapa 
conceitual para explicitar os conceitos envolvidos na formação do conceito de ecossistema e os seus vínculos associativos. O mapa foi criado utilizando-se a ferramenta CMAPTools ${ }^{83}$, um software livre e específico para a elaboração de mapas conceituais. O mapa conceitual encontra-se na figura 23, a seguir:

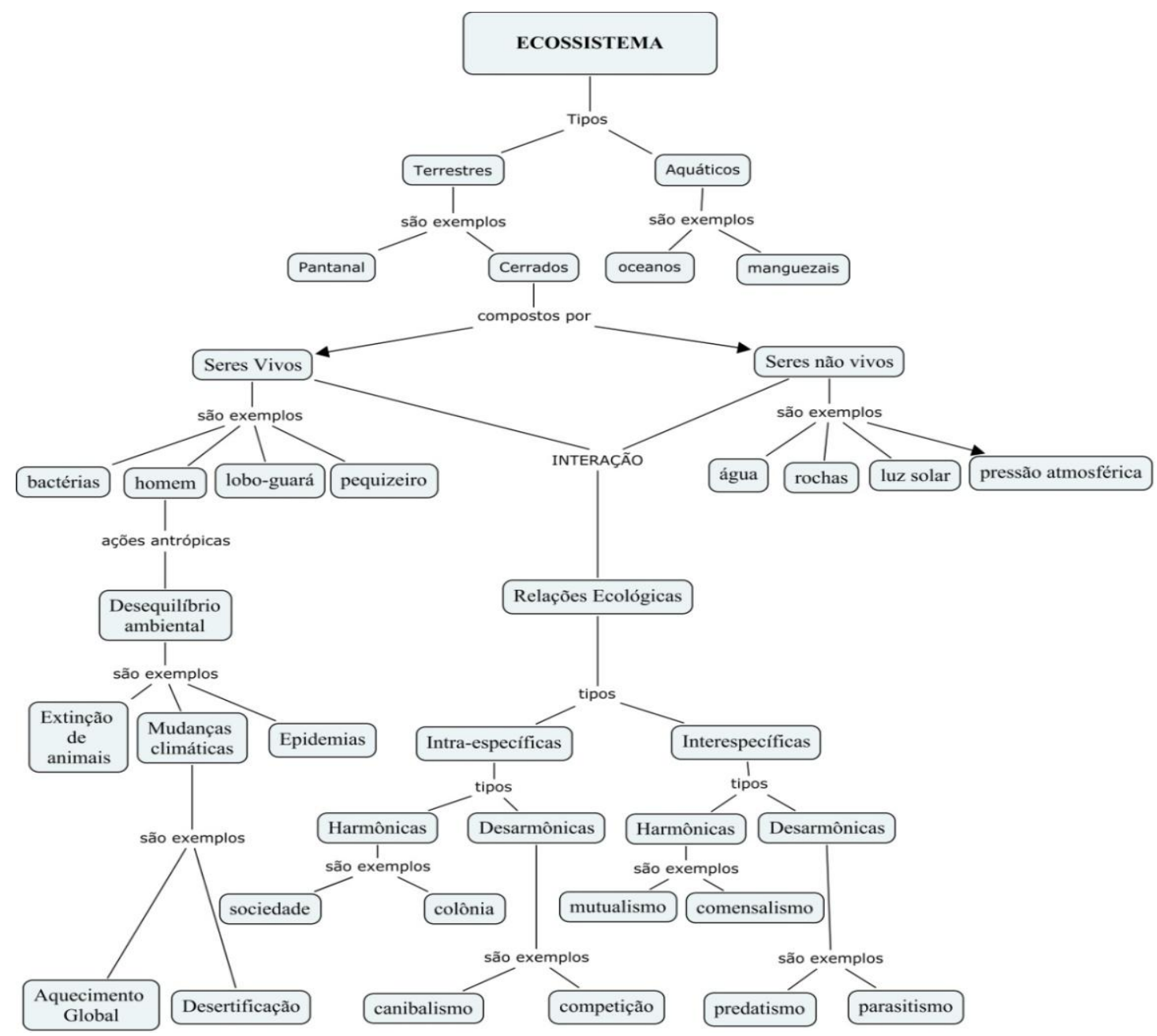

Figura 23. Mapa conceitual sobre ecossistema. Fonte: Autoria própria, adaptado do software CMAP Tools.

A partir do exemplo do ecossistema Cerrado apresentado no mapa conceitual, pode-se observar que a formação do conceito de ecossistema inclui outros conceitos como o de ser vivo, de ser não vivo e de relações ecológicas, sendo estes importantes para a abstração e a generalização para atingir a conceituação.

${ }^{83}$ Consiste em um software para a criação de mapas conceituais, desenvolvido pelo Institute for Human Machine Cognition,University of West Florida, sob a supervisão do Dr. Alberto J. Cañas, que permite ao usuário construir, navegar, compartilhar e criticar modelos de conhecimento representados com mapas conceituais com base nos pressupostos da teoria dos mapas conceituais do estadunidense Joseph Novak. 
Portanto, a relevância do conceito ecossistema deve-se à abrangência do tema e por possibilitar a discussão sobre a preservação e as alterações ambientais, em diferentes áreas do conhecimento no processo educativo dos alunos.

\subsubsection{A escolha do desenho animado}

O uso do desenho animado constitui-se como objeto de estudo da pesquisa. Após a definição do tema, optou-se por retomar o levantamento realizado no catálogo da videoteca ${ }^{84}$ da GTEC $^{85} /$ SEE-DF para a escolha do desenho animado sobre ecossistema, com as seguintes etapas: (i) seleção de vídeos que continham as palavras-chaves animação, desenho animado e filmes de animação; (ii) seleção dos vídeos sobre ecossistemas; e (iii) seleção in loco, para assistir os vídeos escolhidos e identificar se estes apresentavam o conceito de ecossistema.

Os resultados obtidos não foram satisfatórios. Diante deste fato, buscaram-se outras animações que poderiam ser utilizadas na pesquisa e optou-se pelo desenho animado $\mathrm{Meu}$ corpo, meu mundo, da série de animação Anima Saúde da Fundação Oswaldo Cruz FIOCRUZ, produzida pela FIOCRUZ Vídeo.

O DVD Anima Saúde ${ }^{86}$ é composto por três animações: Rattus Rattus, Meu corpo, meu mundo, e A peleja dos guerreiros Sá\&Úde contra os monstros Dó\&Ença no país dos Tropic\&Ais. Na figura 24, apresentada a seguir, tem-se a imagem da capa do DVD e a ficha técnica do desenho animado Меи corpo, meи mundo.

A FIOCRUZ, por meio da FIOCRUZ Vídeo, produz, armazena e disponibiliza recursos audiovisuais com o intuito de disseminar conhecimentos na área de saúde. Com base nesses objetivos, A FIOCRUZ Vídeo apresenta, em sua página virtual ${ }^{87}$, duas linhas de atuação:

a) popularizar e democratizar o acesso da população ao conhecimento em saúde pública por meio da comercialização a baixo custo de DVDs na Editora Fiocruz ou em congressos e feiras; e

\footnotetext{
${ }^{84}$ Local ou ambiente onde se armazena uma coleção de vídeos. No caso da videoteca da SEE-DF, os programas transmitidos pelo TV Escola são gravados em formato digital, estes recebem uma numeração e são organizados por componentes curriculares ou por temas específicos, por exemplo, Educação Especial, Sala do Professor. As cópias dos vídeos são disponibilizadas para empréstimo ou podem ser gravadas em mídia quando solicitadas pela escola ou pelos professores.

${ }^{85}$ Gerência de Tecnologia da SEE-DF.

${ }^{86}$ O DVD Anima Saúde foi adquirido na Editora da FIOCRUZ, localizada na sede da FIOCRUZ Brasília, situada na Avenida L3, s/n, Campus Universitário Darcy Ribeiro, Gleba A, SC 4, Brasília - DF.

${ }^{87}$ Disponível em <http://www.fiocruz.org.br> Acessado em 04. abr. 2013.
} 
b) fomentar e incentivar a produção independente de audiovisuais em saúde, por meio do lançamento de editais de financiamento para a produção e para a finalização de vídeos.

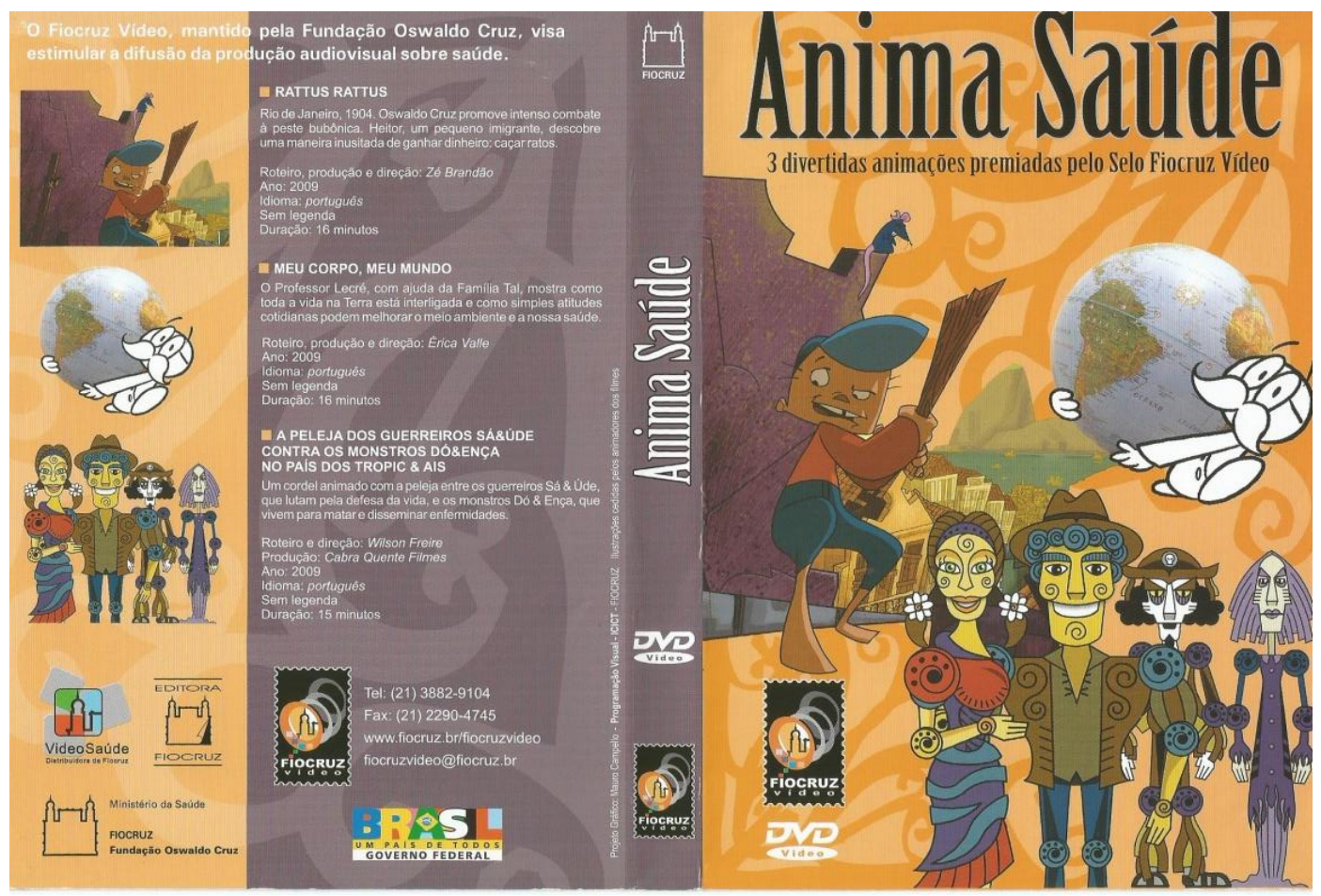

Figura 24. Ficha técnica e capa do DVD Anima Saúde, respectivamente.

O desenho animado Меи согро, теи mundo é narrado pelo professor Lecré (fig. 25), que apresenta a família com o sobrenome Tal e demonstra como a vida na Terra está interligada. As principais personagens da história são o professor Lecré e a família Tal, composta pelo senhor Fulano de Tal, pela senhora Sicrana de Tal e pelo filho único Beltraninho (fig. 25). Trata-se, portanto, de um desenho animado para fins educativos. 


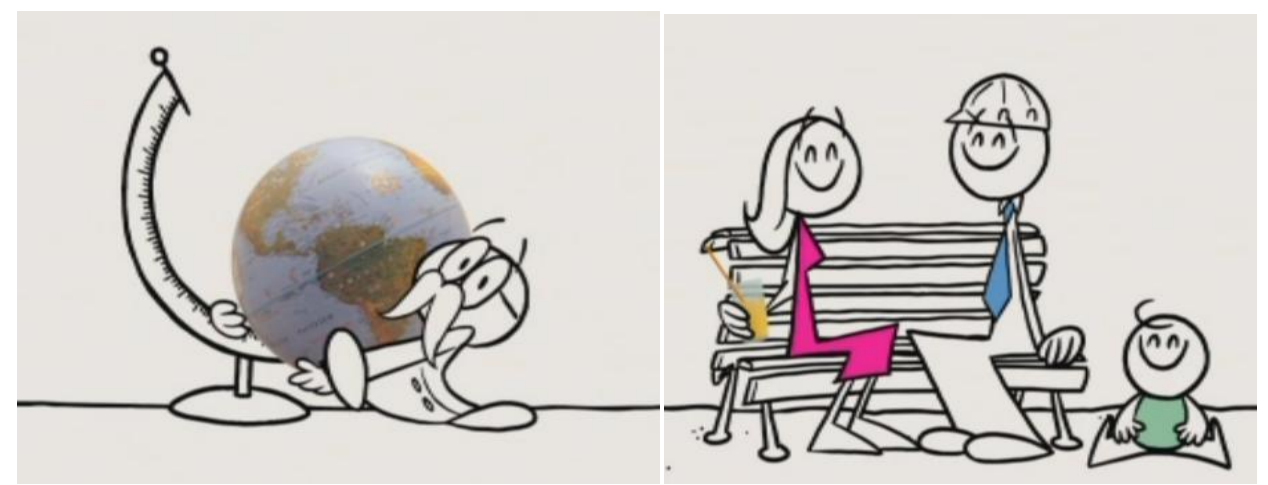

Figura 25. Professor Lecré e Família Tal, respectivamente.

A narrativa aborda o tema ecossistema e apresenta as relações entre os seres vivos e o meio, assim como as ações antrópicas que provocam o desequilíbrio do meio ambiente. $\mathrm{O}$ professor Lecré utiliza as atividades diárias da família Tal para exemplificar como as atitudes humanas influenciam no equilíbrio do ecossistema, para abordar os fatores que contribuem para o aquecimento global e, por fim, para explicitar as consequências para o meio ambiente e para a saúde humana. Após questionar as atitudes da família, o professor Lecré os ensina que a mudança de hábitos e de atitudes pode salvar o planeta, conservar o meio ambiente e, ainda, melhorar a saúde. No presente trabalho, o uso do desenho animado Meu corpo, meu mundo justifica-se por apresentar, em sua narrativa, o conceito de ecossistema.

No contexto da narrativa do desenho animado, outros conceitos são apresentados. No quadro 2, a seguir, listaram-se os conceitos mencionados pelo Professor Lecré, embora nem todos os conceitos citados apresentem definições mencionadas na narrativa. As definições (informações) transmitidas pelo Prof. Lecré foram identificadas em forma de "fragmentos transcritos da narrativa" e o tempo (duração em minutos) em que foram apresentadas durante a exibição do desenho animado.

A elaboração do quadro 2 visava a identificar na fala dos alunos nas atividades 4 e 7 (o contar e o recontar, respectivamente, a história sobre a narrativa do desenho animado) se eles iriam citar os conceitos descritos acima. A transcrição completa do desenho animado encontra-se no Apêndice A e a análise crítica no Apêndice B. 
Quadro 2. Principais conceitos abordados na narrativa do desenho animado Meu corpo, meu mundo.

\begin{tabular}{|c|c|c|c|}
\hline $\begin{array}{l}\text { Número } \\
\text { (Sequência } \\
\text { em que } \\
\text { aparecem) }\end{array}$ & Conceitos abordados & $\begin{array}{l}\text { Fragmentos transcritos da } \\
\text { narrativa do desenho animado } \\
\text { Meu corpo, meu mundo que } \\
\text { definem o conceito abordado }\end{array}$ & $\begin{array}{c}\text { Tempo } \\
\text { (duração } \\
\text { em minutos } \\
\text { e } \\
\text { segundos) }^{88}\end{array}$ \\
\hline $1^{\circ}$ & Gás natural & Retirado do fundo da terra & $1 ' 46 "$ \\
\hline $2^{\circ}$ & Petróleo & $\begin{array}{l}\text { Gera vários tipos de materiais } \\
\text { como o plástico e de } \\
\text { combustíveis como a gasolina. }\end{array}$ & 1'54”' \\
\hline $3^{\circ}$ & Ecossistema & $\begin{array}{c}\text { O convívio em harmonia de } \\
\text { todas as vidas sobre o planeta, } \\
\text { uma dependendo e influindo na } \\
\text { outra. }\end{array}$ & 2’13” \\
\hline $4^{\circ}$ & Energia & $-{ }_{-1----}{ }^{89}$ & 3’27'” \\
\hline $5^{\circ}$ & Usina hidroelétrica & ----- & $3{ }^{\prime} 43$ \\
\hline $6^{\circ}$ & Aquecimento global & $\begin{array}{c}\text { Pode ser o responsável pelas } \\
\text { mais diversas maluquices } \\
\text { climáticas } \\
\end{array}$ & 4'17'” \\
\hline $7^{\circ}$ & Enchentes & ------ & 4'38'” \\
\hline $8^{\circ}$ & Malária & Doenças tropicais & $44^{\prime} 43$ \\
\hline $9^{\circ}$ & Dengue & Doenças tropicais & 4'44'” \\
\hline $10^{\circ}$ & Engarrafamento & $\begin{array}{c}\text { É o que acontece quando todas } \\
\text { as pessoas querem usar cada um } \\
\text { o seu próprio carro }\end{array}$ & $5 ’ 38^{\prime \prime}$ \\
\hline $11^{\circ}$ & Bronquite & 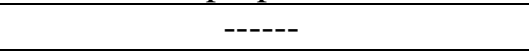 & 5,59 \\
\hline $12^{\circ}$ & Monóxido de carbono & $\begin{array}{l}\text { Faz um mal danado para a nossa } \\
\text { saúde }\end{array}$ & 6’04 \\
\hline $13^{\circ}$ & Gás carbônico & $\begin{array}{c}\text { É um dos grandes vilões do } \\
\text { aquecimento global }\end{array}$ & 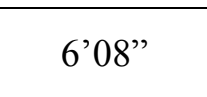 \\
\hline $14^{\circ}$ & Fotossíntese & $\begin{array}{ll}---- \\
\end{array}$ & 6'19" \\
\hline $15^{\circ}$ & Impermeabilizar a terra & $\begin{array}{c}----- \\
--1\end{array}$ & \\
\hline $16^{\circ}$ & Aterros sanitários & ------ & 9’48”' \\
\hline $17^{\circ}$ & Lençóis freáticos & $\begin{array}{c}\text { São canais naturais de água } \\
\text { subterrâneos }\end{array}$ & $10^{\prime} 18^{\prime \prime}$ \\
\hline $18^{\circ}$ & Mosquito da dengue & Gosta de calor e água parada & $11^{\prime} 02 "$ \\
\hline $19^{\circ}$ & Leptospirose & Uma doença que pode até matar & $11 ’ 36 "$ \\
\hline $20^{\circ}$ & Transporte público & -2 & 12’37'” \\
\hline
\end{tabular}

\subsubsection{Locus da pesquisa}

O estudo foi realizado em uma escola e elencaram-se os seguintes critérios para a escolha: ser uma instituição de ensino pública pertencente à SEE-DF e oferecer o nível fundamental da Educação Básica. O estudo foi realizado em uma escola pública do Distrito Federal que oferece diferentes etapas e modalidades da Educação Básica, Educação Infantil e

\footnotetext{
${ }^{88}$ Indica o tempo (minutos e segundos, respectivamente) em que aparece o conceito abordado durante a exibição do desenho animado Meu corpo, meu mundo.

${ }^{89} \mathrm{O}$ símbolo de tracejado indica a ausência de uma definição dentro da narrativa apresentada no desenho animado Meи corpo, meu mundo.
} 
Anos Iniciais do Ensino Fundamental, no período matutino e vespertino. E, ainda oferta a Educação de Jovens e Adultos - EJA no período noturno, totalizando trezentos e noventa alunos, contados os três períodos.

A primeira visita realizada na escola ocorreu antes do início da investigação e teve como objetivo conhecer o ambiente escolar e verificar se a instituição atendia aos requisitos previamente elencados. Em um segundo momento, a proposta de estudo (pré-projeto) foi apresentada para a direção e a professora regente do $5^{\circ}$ ano, que se dispôs a colaborar com a pesquisa.

A partir da apresentação, definiu-se o $5^{\circ}$ ano B como a turma participante da pesquisa, composta por quinze alunos, pertencentes à faixa etária entre dez e treze anos de idade, sendo nove meninas e seis meninos. Ao total, onze alunos participaram efetivamente das atividades propostas. Vale ressaltar que consideramos apenas aqueles alunos que participaram de todas as atividades. Os outros quatro alunos faltaram à maioria das atividades.

A escolha da etapa de ensino (Ensino Fundamental - $5^{\circ}$ ano) justifica-se em função da introdução do tema ecossistema nos anos iniciais. O Currículo em Movimento, no componente curricular de Ciências da Natureza, no tema ambiente, apresenta os seguintes objetivos referentes ao conteúdo ecossistema: (i) reconhecer diversos ambientes e identificar ecossistemas locais; (ii) reconhecer que o ser humano é o principal agente que modifica os ecossistemas; (iii) reconhecer que as relações ecológicas na natureza podem ser harmônicas ou desarmônicas; (iv) indicar num ambiente natural os componentes que constituem esse ecossistema, assim como as relações alimentares entre os seres; e, por último, (v) reconhecer a organização do ecossistema (DISTRITO FEDERAL, 2014b, p. 126-127).Uma vez que o tema ecossistema integra o currículo do $5^{\circ}$ ano do Ensino Fundamental, fica justificada a opção por essa etapa de ensino para a realização do estudo.

\subsection{Atividades realizadas com os alunos}

Após as atividades preliminares com a direção e a equipe pedagógica, procedeu-se à realização das atividades com os alunos. Para a nova proposta metodológica, considerou-se diferentes etapas e as respectivas sub-etapas para analisar como os alunos se apropriam das informações científicas apresentadas na narrativa do desenho animado e como essas informações são articuladas no processo de formação do conceito ecossistema.

As atividades realizadas com os alunos consistem em quatro etapas: (a) período de observação e interação (atividades realizadas para promover a interação entre a entrevistadora e os alunos); (b) atividades pré-exibição (atividades realizadas antes da exibição do desenho 
animado); (c) sessão de desenho animado (atividades realizadas durante a exibição do desenho animado); e (d) atividades pós-exibição (atividades realizadas após a exibição do desenho animado). Nesse momento, cada etapa será descrita com o seu respectivo objetivo.

\section{(a) Período de observação e interação}

Em um primeiro momento, optou-se por realizar um período de observação - uma semana - na escola e na sala de aula, participando das atividades decorrentes das aulas e propondo atividades com o intuito de conhecer os alunos, assim como de os alunos conhecerem a entrevistadora, e também como subsídio para as atividades posteriores.

O contato inicial teve como objetivo a apresentação da entrevistadora aos alunos colaboradores da pesquisa. Nesse mesmo dia, realizou-se a entrega do Termo de Consentimento Livre e Esclarecido - TCLE (Apêndice C), requisito básico para iniciar a investigação. Explicou-se aos alunos a importância do termo e solicitou-se que eles o devolvessem à professora assinado pelos pais ou responsáveis. Nessa nova proposta metodológica, a participação da professora restringiu-se à observação e ao acompanhamento das atividades desenvolvidas.

Em um segundo momento, com os termos em mão, iniciou-se a primeira atividade para a qual os alunos foram solicitados a elaborar uma lista de seres vivos e não vivos que posteriormente iria subsidiar a seleção das imagens fixas a serem utilizadas na atividade subsequente (3.1). Para a compilação dos dados, cada aluno citou um ser vivo e um ser não vivo da sua lista individual, que foram relacionados no quadro branco.

Após a elaboração da lista, os alunos sentaram em círculo para uma roda de conversa com o intuito de familiarizar o uso do gravador, que seria utilizado nas atividades posteriores e nas entrevistas individuais. Além disso, a roda de conversa possibilitou a interação da entrevistadora com os alunos, que resultou na maior disposição dos alunos a participar das atividades propostas. Iniciou-se a roda de conversa sobre o uso e as funções do gravador e depois com perguntas abertas como: Vocês gostam de Ciências? O que vocês mais gostam quando estudam Ciências? E, ainda, a partir de questões levantadas pelos próprios alunos durante as discussões.

Ao final da roda de conversa, foi proposta uma brincadeira intitulada de Entrevista sobre os seres vivos, na qual se solicitou aos alunos a realização das seguintes tarefas: (1) escolher um ser vivo da lista elaborada anteriormente e compilada no quadro branco; (2) confeccionar uma máscara que representasse o ser vivo escolhido; (3) escolher um colega para trabalhar em dupla; (4) elaborar cinco perguntas que um ser vivo faria para o outro, entre 
as quais deveria ser citado um ser não vivo da lista compilada anteriormente nas perguntas elaboradas; (5) proceder a uma entrevista utilizando as perguntas elaboradas e o gravador. Os objetivos da brincadeira foram: possibilitar que os alunos interagissem com o principal instrumento da presente pesquisa realizada pela entrevistadora; permitir posteriormente que eles escutassem a voz gravada; e, avaliar a noção que os alunos possuem de seres vivos a partir das questões e respostas elaboradas por eles. As entrevistas foram gravadas simultaneamente e as máscaras confeccionadas foram escaneadas e salvas em formato $\mathrm{JPEG}^{90}$.

\section{(b) Atividades pré-exibição}

Posteriormente ao período de observação, iniciaram-se as atividades da pré-exibição, com o intuito de identificar os conceitos cotidianos (conhecimentos prévios) dos alunos, especificamente sobre o tema ecossistema.

\section{(b.1) Atividade 1: solicitação de desenho e texto sobre ecossistema}

Para iniciar a atividade, a palavra ecossistema foi escrita em letras garrafais no quadro branco e levantou-se a seguinte questão: Vocês já ouviram essa palavra antes? A pergunta visava a identificar as ideias e os significados atribuídos ao termo pelos alunos. Após as respostas e os comentários, a atividade foi aplicada da seguinte maneira: (1) entregou-se a folha de papel sulfite branco aos alunos; (2) solicitou-se aos alunos a elaboração de um desenho que representasse um ecossistema; (3) após a confecção do desenho, solicitou-se aos alunos a explicação por meio de texto, no verso da folha, sobre como é a vida em um ecossistema.

O objetivo desta atividade foi utilizar o desenho para possibilitar a criação de situações dialógicas sobre o tema ecossistema nas entrevistas individuais que foram realizadas posteriormente. Os desenhos produzidos foram escaneados e salvos em formato JPEG.

\section{(b.2) Atividade 2:entrevista individual sobre os desenhos produzidos}

As entrevistas individuais e semiestruturadas foram realizadas a partir dos desenhos e textos explicativos dos alunos. Segundo Augusto Triviños, entende-se por entrevista semiestruturada:

\footnotetext{
${ }^{90}$ Joint Photographics Experts Group, expressão no idioma inglês que designa um tipo de formato de arquivo de imagens.
} 
[...] aquela que parte de certos questionamentos básicos, apoiados em teorias e hipóteses, que interessam à pesquisa, e que, em seguida, oferecem amplo campo de interrogativas, fruto de novas hipóteses que vão surgindo à medida que se recebem as respostas do informante. Desta maneira, o informante, seguindo espontaneamente a linha de seu pensamento e de suas experiências dentro do foco principal colocado pelo investigador, começa a participar na elaboração do conteúdo da pesquisa (TRIVIÑOS, 1987, p. 146).

O autor complementa que a entrevista semiestruturada "[...] favorece não só a descrição dos fenômenos sociais, mas também sua explicação e a compreensão de sua totalidade" (TRIVIÑOS, 1987, p. 152). Este tipo de entrevista permite, ainda, a elaboração de um roteiro prévio que possibilita a flexibilidade das perguntas com base nos diferentes elementos presentes em cada desenho e das informações do texto contidas no verso do desenho.

As entrevistas individuais tinham como objetivo fornecer pistas sobre o conhecimento que os alunos possuíam referente ao tema ecossistema. As entrevistas iniciaram-se com perguntas do tipo: O que você pensou quando fez esse desenho? Tenta me explicar? Qual é a relação entre os elementos do seu desenho? O que compõe o seu ecossistema? Você pode me explicar como ele funciona?

As entrevistas foram gravadas simultaneamente e, posteriormente, transcritas para a análise dos dados gerados.

\section{(b.3) Atividade 3:seres vivos, seres não vivos e relações ecológicas}

\section{(b.3.1) Seres vivos e não vivos}

Antes da primeira exibição do desenho animado Мeu corpo, meu mundo, os alunos foram solicitados a realizar uma atividade que consistiu em: (1) identificar as imagens; (2) separar as imagens em dois grupos, seres vivos e seres não vivos; e (3) agrupar os seres vivos. A atividade ${ }^{91}$ teve como intuito verificar o conceito de ser vivo dos alunos, quais critérios eles utilizaram para classificar em ser vivo e ser não vivo e se identificaram as relações entre eles.

Para a seleção de imagens de seres vivos, utilizou-se como critério aquelas que contemplassem os reinos da classificação biológica na seguinte proporção: Monera (1), Protista (1), Fungi (1), Plantae (6) e Animalia (12). Para a seleção das imagens de seres não vivos, selecionaram-se aquelas importantes na compreensão do conceito ecossistema que interferem na inter-relação entre os seres vivos como o sol, a água e os minerais. Os

\footnotetext{
${ }^{91}$ Esta metodologia foi desenvolvida por Carneiro (1997).
} 
resultados das listas (seres vivos e não vivos) elaboradas pelos alunos no período de observação também foram utilizados como critério para a seleção das figuras.

As imagens foram retiradas do livro Seres Vivos, do Projeto CTC (SANGARI BRASIL, 2007) (Anexo 1) e outras foram retiradas de um sítio eletrônico ${ }^{92}$ de busca por imagens na internet. Ao total, selecionaram-se vinte e cinco imagens, entre elas: água, alga, anta, aranha, árvore, bactéria, bola, cogumelo, esponja, girafa, libélula, musgo, peixe, sol e tuiuiú. As entrevistas foram gravadas simultaneamente e, posteriormente, transcritas para a análise dos dados gerados.

\section{(b.3.2) Relações ecológicas}

Esta atividade subdividiu-se em duas etapas durante a aula. A primeira foi o jogo da teia alimentar, adaptado de Telles et al (2002), com o objetivo de os alunos perceberem a interdependência entre os seres vivos e não vivos. Os alunos foram convidados a sentarem em círculo e, antes de iniciar a atividade, perguntou-se "Quem é ser vivo aqui?", com o intuito de abordar os conceitos de ser vivo e ser não vivo e retomar as características de cada um.

A entrevistadora enrolou o fio de novelo de barbante no dedo e jogou-o para outro (a) aluno (a) que responderia a seguinte pergunta: Quem come a cenoura? O aluno (a) que pegou o novelo enrolava o fio de barbante no dedo, respondia a pergunta e escolhia outro aluno para prosseguir o jogo. Os conceitos de seres vivos produtores, herbívoros, carnívoros e decompositores foram trabalhados durante o jogo. Quando o último nível de consumo (carnívoro) era atingido, a brincadeira reiniciava começando por um ser vivo produtor. Os alunos permaneciam com o barbante enrolado no dedo. Ao final, os alunos foram capazes de compreender que se tratava de várias cadeias alimentares que formavam uma teia alimentar. A atividade foi gravada, filmada simultaneamente e transcrita posteriormente para a análise dos dados obtidos.

Na segunda parte, realizou-se uma atividade individual que consistiu na elaboração da cadeia alimentar para discutir os conceitos como produtores, herbívoros, carnívoros e decompositores, desenvolvidos na atividade, que são importantes para a compreensão das relações ecológicas, que é um atributo para a apreensão do conceito ecossistema. A entrevistadora distribuiu folhas de papel brancas que representavam um ambiente terrestre e folhas azuis, que representavam um ambiente aquático.

\footnotetext{
${ }^{92}$ Disponível em:<http://www.google.com.br>. Acessado em: 30 nov. 2014
} 
As figuras de animais foram distribuídas no piso da sala para os alunos selecionarem e montarem a sua cadeia alimentar. Ao total, disponibilizaram-se quatro figuras de cada uma das trinta e três espécies de seres vivos distribuídas em oito classes, na seguinte proporção: Anelídeos (1), Anfíbios (4), Aves (5), Insetos (6), Mamíferos (7), Peixes (5) e Répteis (5). Além dessas, foram disponibilizadas também as imagens utilizadas na atividade 3.1 (Seres vivos e não vivos). No Apêndice D, apresentam-se oito espécies representantes das classes citadas.

Os alunos também foram instruídos a desenharem o animal ou o vegetal que não estava contemplado nas figuras distribuídas para o uso dos alunos na montagem da cadeia, por exemplo, o aluno pensou em uma cadeia alimentar composta pela figura da onça, do macaco e da banana, esta última não estando representada pela imagem impressa. Então, os alunos poderiam desenhar para completar a cadeia. As cadeias alimentares elaboradas pelos alunos foram escaneadas e salvas em formato JPEG para posterior análise dos dados gerados.

\section{(c) Sessão de desenho animado}

A sessão é definida como cada aula em que ocorre a exibição do desenho animado ou parte dele. Ao total, foram realizadas três sessões. A primeira sessão é a exibição completa do desenho animado Meu corpo, meu mundo (16 minutos), sem interrupções. Na segunda e na terceira sessão, ocorreram pausas durante a exibição.

\section{(c.1) Sessão 1}

A primeira sessão é a exibição completa do desenho animado sem interrupções. Antes de iniciar a sessão, levantaram-se algumas questões sobre o desenho animado como: Vocês gostam de desenhos animados? Vocês imaginam qual será esse desenho animado? Quais desenhos animados vocês assistiram aqui na sala?

Além disso, retomaram-se os conceitos de ser vivo, de ser não vivo, de cadeia alimentar e, ainda, de ecossistema. As questões foram: Vocês lembram o que é um ser vivo? E os seres não vivos? Quais são aqueles dos quais nós dependemos? E o que é uma cadeia alimentar? O que é um ecossistema?

Para uma melhor visualização, as carteiras dos alunos foram dispostas uma ao lado da outra formando um semicírculo. O desenho animado foi projetado no quadro branco da 
própria sala de aula e utilizou-se o equipamento da escola denominado Computador Interativo e Lousa Digital ${ }^{93}$ (fig. 26).
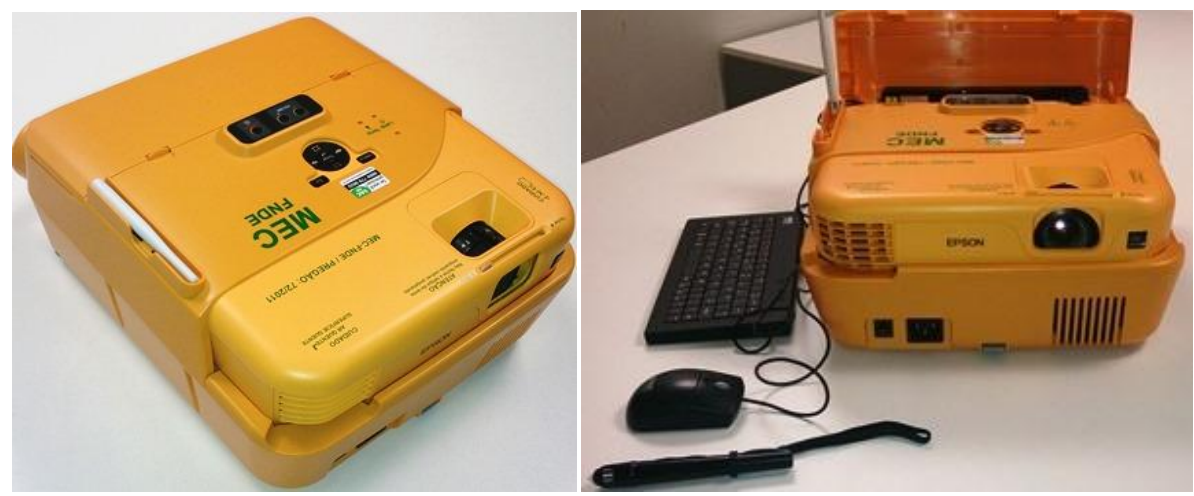

Figura 26. Computador Interativo e Lousa Digital. Fonte: http://www.fnde.gov.br/portaldecompras/index.php/ produtos/computador-interativo-projetor. Acesso em: 15. dez. 2014.

\section{Atividade 4: Contação de história}

Após a sessão 1, os alunos produziram um texto individual com o objetivo de contar a história do desenho animado para verificar a compreensão da narrativa. Para a elaboração do texto, entregou-se uma folha de papel sulfite azul com o a imagem do planeta (fig. 27) para remeter ao título do desenho animado Meu corpo, meu mundo. Também foi solicitada aos alunos a opinião deles sobre a história.

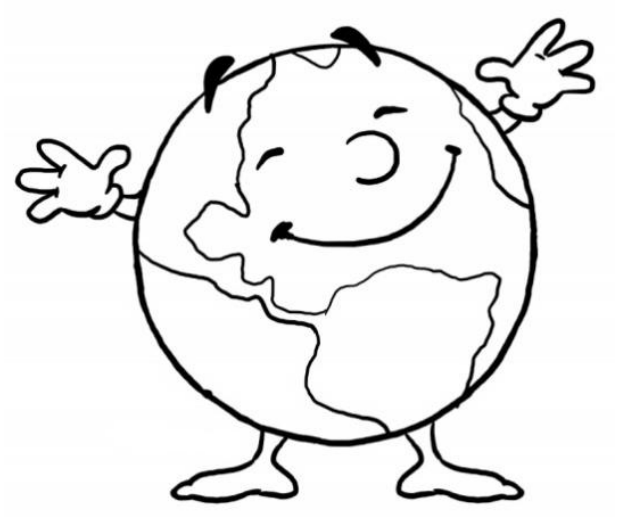

Figura 27. Imagem utilizada na folha disponibilizada aos alunos para a produção de texto na Atividade 4. Fonte: http://desenhosparacolorir2.com.br/wp-content/uploads/2013/07/desenhos-para-colorir-mundo.jpg. Acesso em: 1 nov. 2014.

93 De acordo com a página virtual do Fundo Nacional de Desenvolvimento da Educação, o Computador Interativo (projetor multimídia), concebido e desenvolvido pelas Universidades Federais de Santa Catarina e de Pernambuco, diferencia-se por possibilitar a interatividade. O equipamento é interligado aos laboratórios do Programa Nacional de Formação Continuada em Tecnologia Educacional - ProInfo e contém teclado, mouse, portas USB (Universal Serial Bus), porta para redewireless e rede PLC (Power Line Communication), unidade leitora de DVD e um projetor multimídia. O dispositivo pode ainda operar como uma lousa digital, transformando a superfície de projeção em um quadro interativo. 


\section{Atividade 4.1: Descrição das cenas da narrativa do desenho animado}

No segundo momento da aula, os alunos foram convidados a escolher um recorte da cena do desenho animado. As cenas de cada minuto (1' - 15') do desenho animado foram decupadas $^{94}$, impressas, coladas em folha de papel sulfite azul. Os recortes das cenas foram colocados no piso da sala e viradas com a face impressa para baixo, de modo que não permitisse aos alunos visualizar qual era a cena. As cenas decupadas encontram-se no quadro 3 , a seguir.

Os alunos foram sorteados para escolher o recorte e descrever o que aconteceu na cena escolhida, com o objetivo de verificar a compreensão dos fatos que ocorreram na narrativa do desenho animado. Após a explicação, eles foram solicitados a fixar a cena escolhida com fita crepe no quadro branco e a enumerá-la. O número (de 1 a 15) escolhido foi afixado por cima da cena escolhida e correspondia ao tempo (minutos) em que o aluno se recordava de ter acontecido naquela cena.

Quadro 3. Cenas decupadas por minuto com as imagens correspondentes.

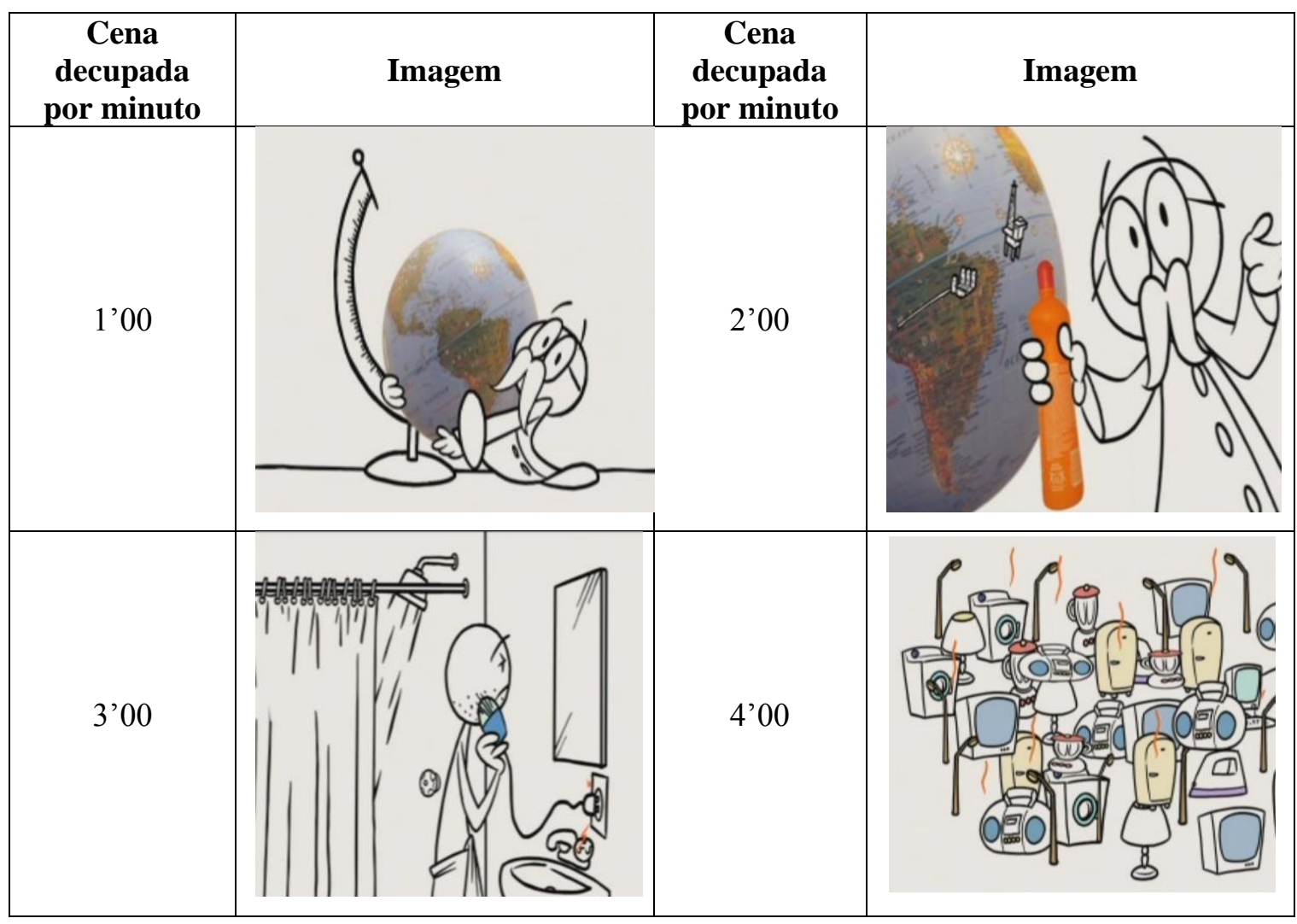

${ }^{94}$ Neste caso, a decupagem são os recortes das cenas do desenho animado utilizadas no desenvolvimento das atividades da nova metodologia. Para a obtenção das imagens, utilizou-se a função print screen do computador quando o desenho estava sendo exibido e depois a imagem foi formatada no programa Microsoft Word. 


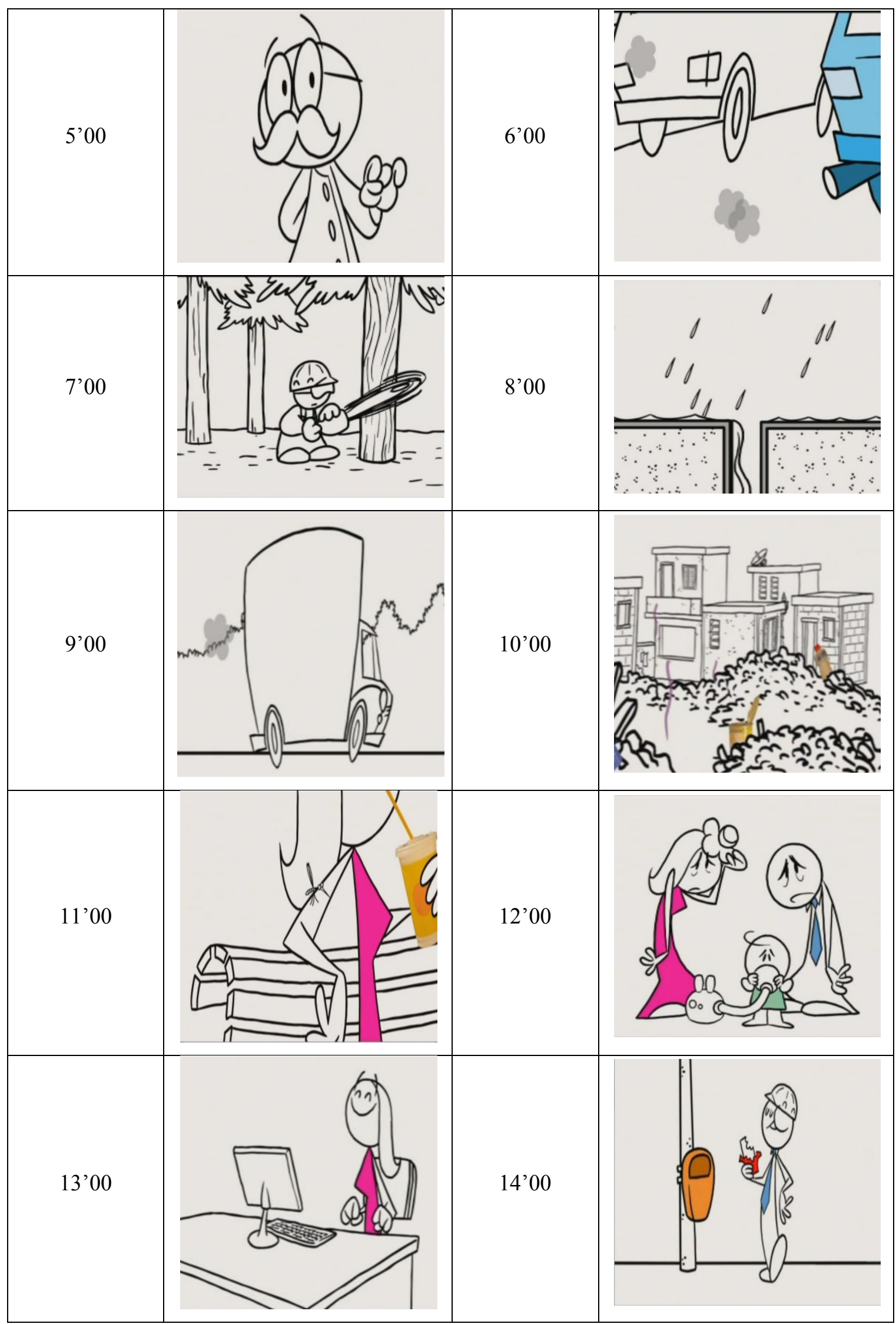




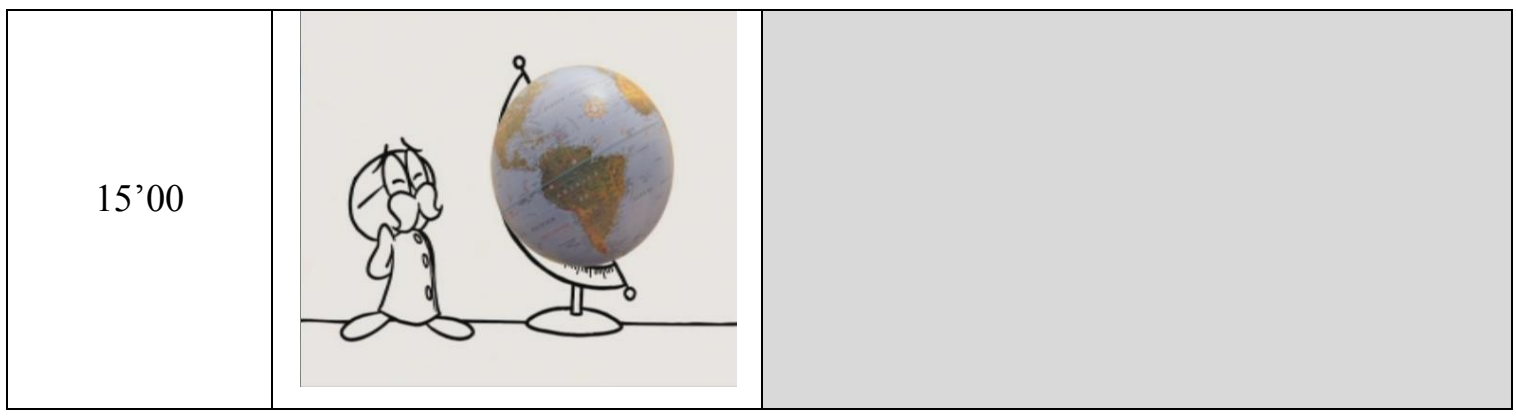

\section{(c.2) Sessão 2}

Após a exibição completa, o desenho foi reexibido com os momentos de pausa descritos abaixo, com a finalidade de promover o debate e as discussões para que ocorressem as interações dialógicas sobre o tema. Os momentos de pausa coincidem com as assertivas e os questionamentos levantados pelo Professor Lecré. Além disso, elaboraram-se outros questionamentos, considerados complementares, para enriquecer o debate promovido e para gerar discussões.

\section{Atividade 5: Debate 1}

Antes de iniciar o debate, ocorreu a reexibição dos cinco primeiros minutos (sem pausas) do desenho animado Meи corpo, meu mundo e, posteriormente, realizaram-se as pausas previstas no quadro 4, a seguir, a fim de desenvolver o conceito de ecossistema.

O quadro 4 apresenta as cenas decupadas e selecionadas do desenho animado, o tempo (duração em minutos e segundos) dos momentos de pausa e os questionamentos do Prof. Lecré, assim como aqueles complementares utilizados no debate.

Quadro 4. Momentos de pausa, assertivas e questionamentos referentes à Atividade 5.

\begin{tabular}{|c|c|l|}
\hline $\begin{array}{c}\text { Momentos } \\
\text { de pausa }\end{array}$ & Imagem & \multicolumn{1}{c|}{ Assertivas e questionamentos } \\
\hline $\begin{array}{c}\text { 1'pausa } \\
\text { (1'07") }\end{array}$ & $\begin{array}{l}\text { Assertiva 1: "Uma gota de vida boiando no } \\
\text { universo em perfeita harmonia!" (transcrição da } \\
\text { fala do Prof. Lecré) }\end{array}$ \\
$\begin{array}{l}\text { A. Quais seriam os cuidados que a Terra } \\
\text { precisa? } \\
\text { B. Você já pensou que tudo que precisa para } \\
\text { se viver vem do planeta? (transcrição da fala do } \\
\text { Prof. Lecré) Dê exemplos. }\end{array}$ \\
\hline
\end{tabular}




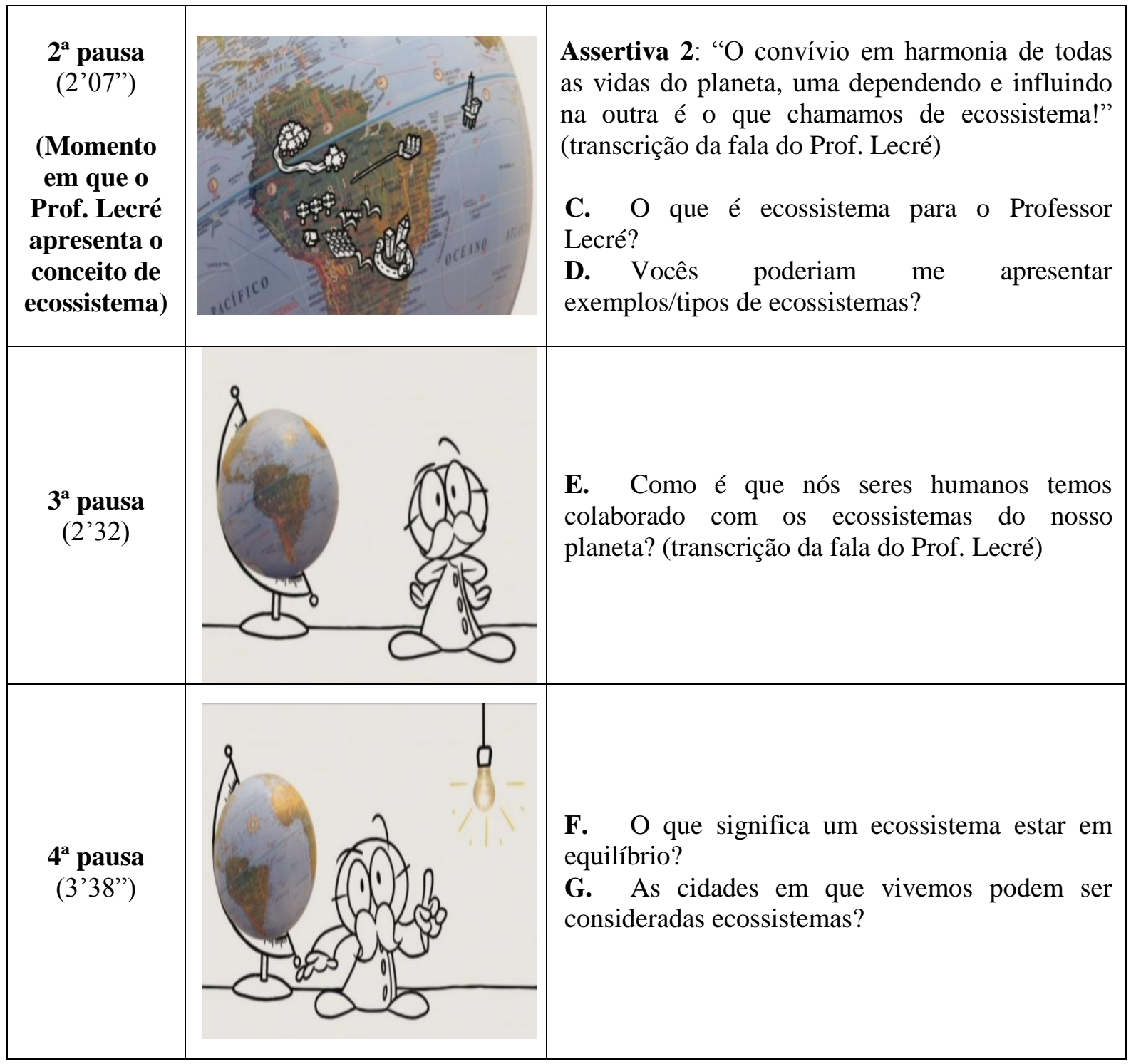

A turma foi dividida em dois grupos (Grupo A e Grupo B) para a promoção do debate. Um aluno era escolhido pelo grupo para responder uma das perguntas correspondentes às pausas e os integrantes dos grupos foram instruídos a colaborar nas respostas quando necessário para ampliar as discussões. O debate foi filmado e gravado simultaneamente para posterior análise dos dados gerados.

\section{(c.3) Sessão 3}

\section{Atividade 6: Debate 2}

Na sessão 3, a reexibição começou a partir do cinco minutos em diante, com as pausas previstas. Em seguida, os grupos A e B foram mantidos para dar continuidade às discussões dos momentos de pausa previstos no quadro 5, a seguir. 
Quadro 5. Momentos de pausa, imagens, assertivas e questionamentos referentes à Atividade 6.

\begin{tabular}{|c|c|c|}
\hline $\begin{array}{c}\text { Momentos } \\
\text { de pausa }\end{array}$ & Imagem & Assertivas e questionamentos \\
\hline $\begin{array}{c}\mathbf{1}^{\mathbf{a}} \text { pausa } \\
(11,58)\end{array}$ & & $\begin{array}{l}\text { Assertiva 3: "Ah, se vocês pudessem } \\
\text { acordar de novo, hein? O que vocês } \\
\text { fariam?" (transcrição da fala do Prof. } \\
\text { Lecré) }\end{array}$ \\
\hline $\begin{array}{l}\mathbf{2}^{\mathbf{a}} \text { pausa } \\
\left(12^{\prime} 02^{\prime \prime}\right)\end{array}$ & & $\begin{array}{l}\text { Assertiva 4: "Vejamos o que eu posso } \\
\text { fazer por vocês!" (transcrição da fala do } \\
\text { Prof. Lecré) } \\
\text { H. Quais seriam as soluções, atitudes e } \\
\text { propostas para reduzirmos os efeitos no } \\
\text { ecossistema provocados pela poluição e } \\
\text { pelo aquecimento global? }\end{array}$ \\
\hline
\end{tabular}

Após a primeira pausa, solicitou-se aos grupos que escolhessem cinco causas e cinco consequências apresentadas na narrativa do desenho sobre as ações antrópicas danosas provocadas no ecossistema e foi estipulado quinze minutos para cada grupo para a promoção do debate entre os alunos e, posteriormente, a escolha das causas e das consequências deveriam ser redigidas em folhas de papel sulfite azul e amarelo, respectivamente. Na sequência, um aluno de cada equipe foi chamado a afixar no quadro as folhas e declarar as causas e as consequências elencadas pelo grupo. O grupo tinha a liberdade para complementar a explicação do aluno que os representava.

$\mathrm{Na}$ segunda pausa, os grupos foram solicitados a redigir, em folhas brancas de papel, as soluções de preservação do ecossistema para cada relação de causa e consequência anteriormente estabelecida.

O objetivo da atividade 6 era abordar as causas, as consequências e as soluções provocadas pelas alterações no ecossistema decorrentes das ações antrópicas que versavam na narrativa do desenho animado. As discussões dos grupos foram gravadas e filmadas, concomitantemente, para a análise posterior dos dados gerados. O material produzido pelos alunos foi escaneado e salvo em formato JPEG. 


\section{(d) Atividades pós-exibição}

\section{Atividade 7: Recontar a história da narrativa do desenho animado}

As atividades pós-exibição constituem-se em atividades que foram realizadas após a exibição do desenho animado. Nesta atividade, os alunos tiveram que recontar a história do desenho animado Meи corpo, meu mundo usando a palavra-chave ecossistema. O objetivo desta atividade foi identificar na fala dos alunos como eles irão empregar a palavra ecossistema para recontar oralmente a história do desenho animado para a entrevistadora. E, ainda, se os alunos irão citar outros conceitos apresentados no quadro1 deste Capítulo.

Para a realização desta atividade, utilizaram-se os mesmos recortes utilizados na atividade 4. Porém, no verso de cada cena, encontravam-se impressas três palavras-chave relacionadas à imagem (quadro 6), cabendo salientar que todas elas continham a palavrachave ecossistema. Criou-se uma situação de aprendizagem em que os alunos escolhiam uma cena e, a partir das palavras-chave, deveriam recontar oralmente a história do desenho animado. No quadro 6, a seguir, encontram-se as cenas decupadas por minuto, as respectivas imagens e as palavras-chave utilizadas em cada cena.

Quadro 6. Cenas decupadas, imagens e palavras-chave referentes à Atividade 7.

\begin{tabular}{|c|c|c|}
\hline $\begin{array}{c}\text { Cena } \\
\text { decupada por } \\
\text { minuto }\end{array}$ & Imagem & Palavras-chave \\
\hline 1 '00 & UNIVERSO & PLANETA TERRA \\
\hline & ECOSSITEMA & GÁS NATURAL \\
\hline & PETRÓLEO
\end{tabular}




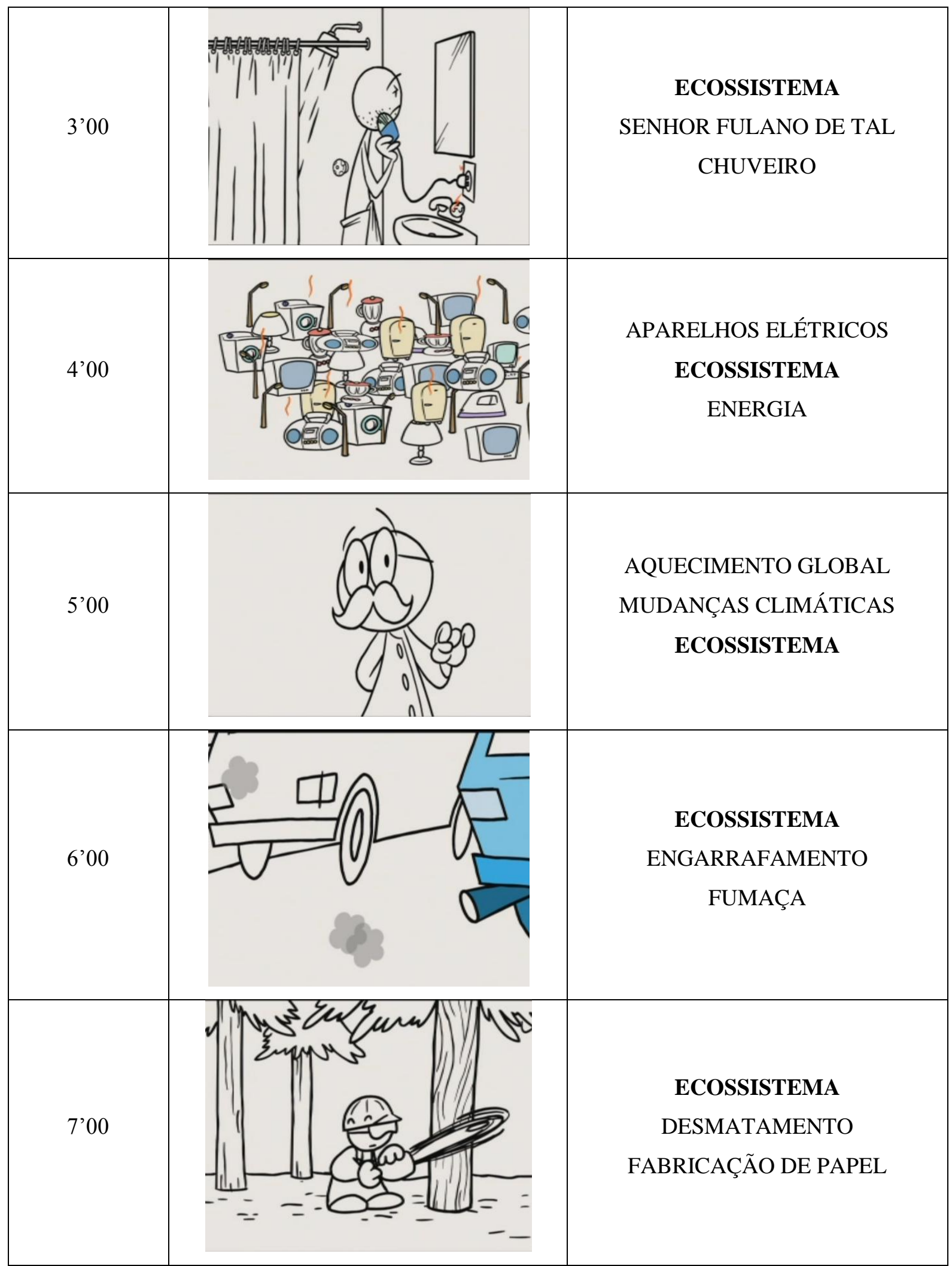




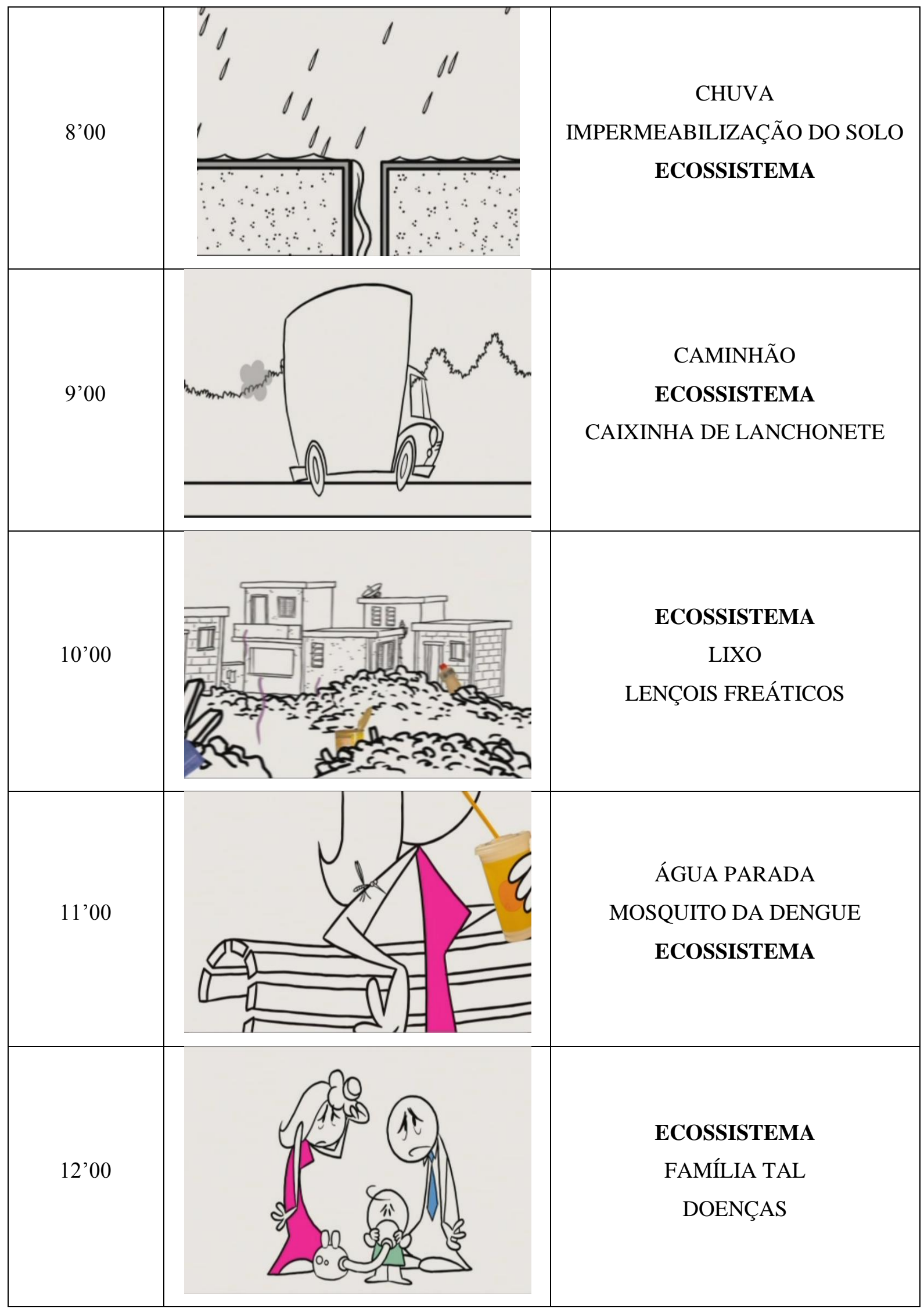




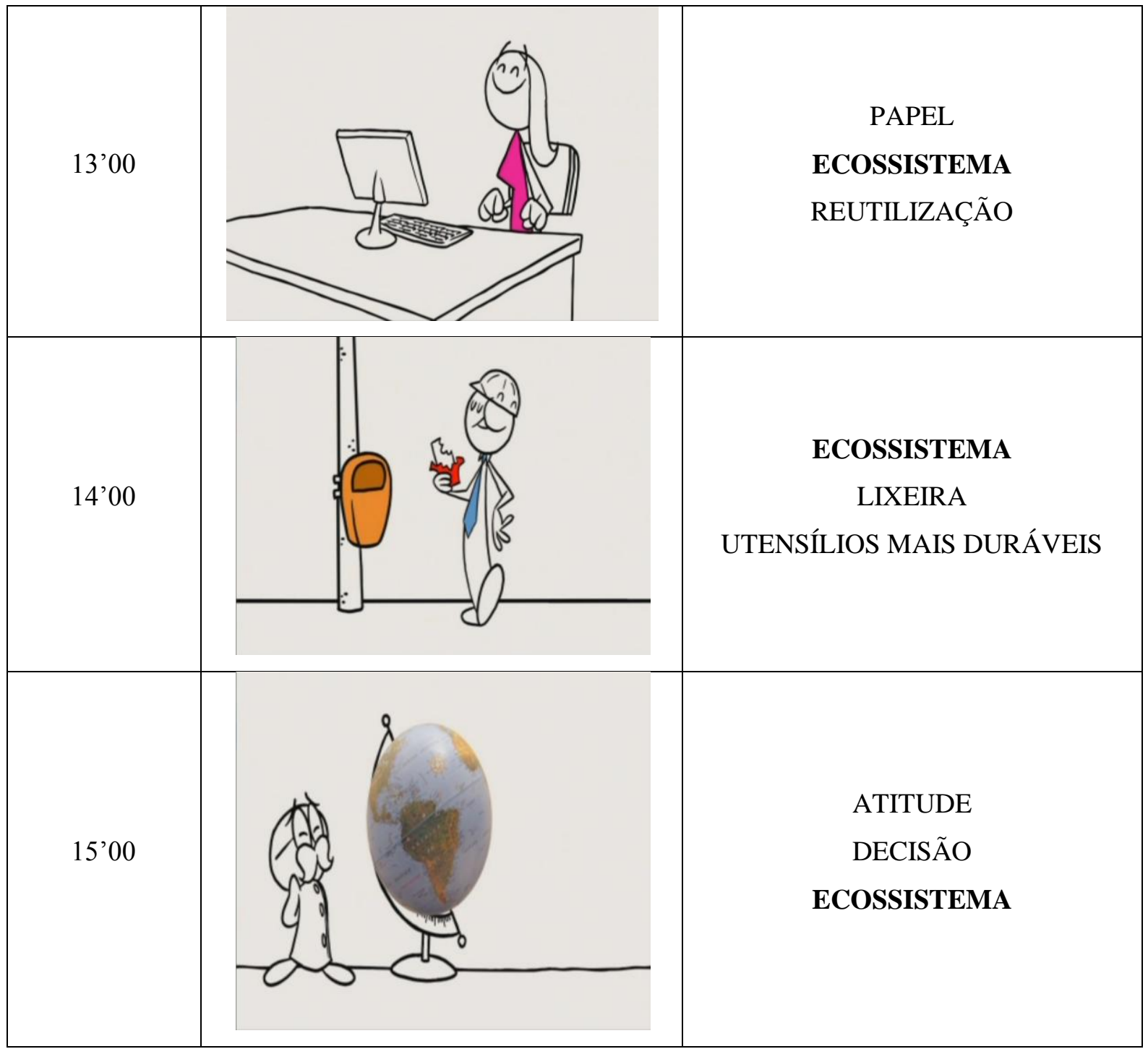

A atividade 7 foi gravada simultaneamente para a geração dos dados e a análise posterior.

\section{Atividade 8: Relações ecológicas do Cerrado}

Na penúltima atividade, o desenho animado Aventuras com os Kratts (EUA, 2011. Título original: Wild Kratts), episódio A cadeia alimentar (Parte $1^{95}$ e Parte $2^{96}$ ), foi exibido em sala de aula utilizando o computador interativo e a lousa digital conectada à internet. A princípio, o uso deste desenho animado não estava previsto na metodologia, a opção por utilizá-lo deve-se ao fato de os alunos perceberem o habitat de origem dos animais do zoológico citados na lista de seres vivos referente à atividade realizada no período de

\footnotetext{
${ }^{95}$ Disponível em:https://www.youtube.com/watch?v=dfw6b8yyLa0. Acesso em: 2 dez. 2014.

${ }^{96}$ Disponível em: https://www.youtube.com/watch?v=7W4fscIE_DQ. Acesso em: 2 dez. 2014.
} 
observação e interação. Além disso, a exibição desse episódio visava a criar uma situação de aprendizagem que estimulasse os alunos para a elaboração da atividade 8 .

A série de animação Aventuras com os Kratts(fig. 28) é transmitida pelos canais de televisão por assinatura Discovery Kids e Futura. Os irmãos Kratts são os principais personagens e viajam pelo mundo à procura de animais selvagens que estejam em situação de risco ou envolvidos em algum mistério a ser desvendado. Os irmãos usam discos de poder, criados por sua amiga Aviva, os quais lhes permitem usar os poderes e as habilidades dos animais em que são transformados. Os irmãos Kratts possuem um quartel-general móvel denominado Tartaruga. Outros dois personagens integram a equipe: Koki, a especialista em computadores, e Jimmy Z, o atrapalhado piloto do quartel Tartaruga.

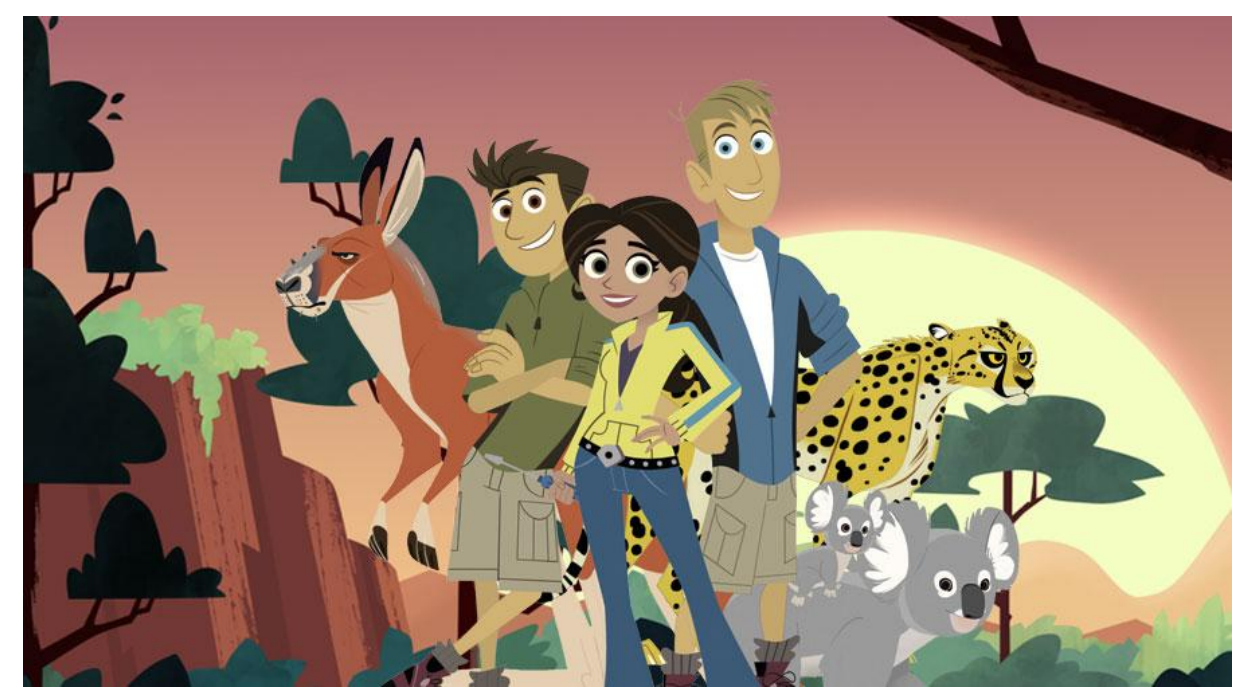

Figura 28. Chris, Aviva e Martin são as personagens do desenho animado Aventuras com os Kratts. Fonte: http://discoverykidsbrasil.uol.com.br/personagens/aventuras-com-os-kratts/. Acesso em: 10 nov. 2014.

No episódio A cadeia alimentar, Aviva cria um jogo sobre a teia alimentar para ver como a energia se move no ecossistema africano (savana africana). Os irmãos Kratts participam do jogo como seres vivos, utilizando os discos de poder e o super-traje de animais africanos. Eles começam na base da cadeia alimentar como uma folha de grama e têm que achar um animal que coma grama para ascender na cadeia alimentar. Durante o desafio, descobrem as complexas relações entre os seres produtores, consumidores (herbívoros e carnívoros) e predadores (carnívoros). A transcrição completa do episódio utilizado encontrase no Apêndice E.

Após a exibição completa, comentou-se sobre o ecossistema da savana africana e levantaram-se questões como: Qual o ecossistema em que vivemos? Quais animais do Cerrado vocês conhecem? 
Para a realização da atividade 8 , entregou-se uma folha com a representação de seres não vivos como o sol, as nuvens e o solo e, com aspectos geográficos, referentes ao relevo que formava uma paisagem conforme a figura 29 , a seguir.

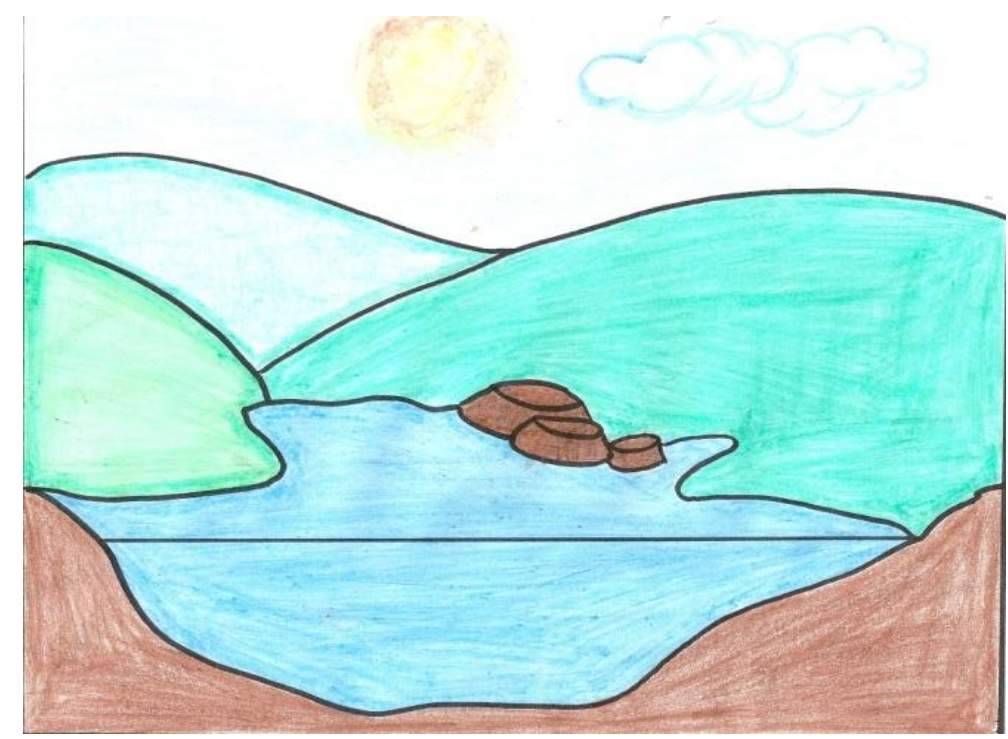

Figura 29. Esquema do aspecto geográfico do Cerrado utilizado na Atividade 8. Fonte: http://5thgradecedarfork.weebly.com. Adaptado da imagem original. Acesso em: 1 nov. 2014.

Além da imagem do aspecto geográfico, também foi entregue aos alunos um conjunto de imagens fixas de seres vivos conforme o quadro 7, a seguir. Os critérios para a seleção das figuras de seres vivos foram espécies ${ }^{97}$ que habitam o Cerrado e que pudessem identificar relações ecológicas (no nível de cadeia alimentar) entre os seres vivos escolhidos. A escolha do Cerrado justifica-se por ser o ecossistema da área geográfica em que se situa o Distrito Federal. Este ecossistema é reconhecido como a savana mais rica em biodiversidade ${ }^{98}$.

Os alunos foram solicitados a montar as relações ecológicas alimentares do Cerrado utilizando o esquema e as figuras entregues. A opção de utilizar um esquema possibilitaria verificar se os alunos iriam relacionar os dois ambientes (terrestre e aquático), estabelecer as relações ecológicas entre os seres vivos e, também, subsidiar a criação de situações dialógicas na entrevista final.

\footnotetext{
${ }^{97}$ Para a seleção de alguns seres vivos utilizou-se a lista de espécies do Cerrado compilada pelo Projeto Fauna DF do Instituto Brasília Ambiental - IBRAM-DF. Disponível em: http://www.ibram.df.gov.br/component/content/article/273.html. Acesso em: 1 nov. 2014.

${ }_{98} \mathrm{O}$ Cerrado apresenta riquíssima flora, com mais de 10 mil espécies de plantas, sendo 4.400 endêmicas. A fauna apresenta 837 espécies de aves, 67 gêneros de mamíferos, abrangendo 161 espécies e 19 endêmicas; 150 espécies de anfíbios, das quais 45 endêmicas; 120 espécies de répteis, sendo 24 endêmicas (MITTERMEIER $e t$ $a l, 1999)$.
} 
Quadro 7. Imagens fixas de seres vivos do ecossistema Cerrado utilizadas na Atividade 8.

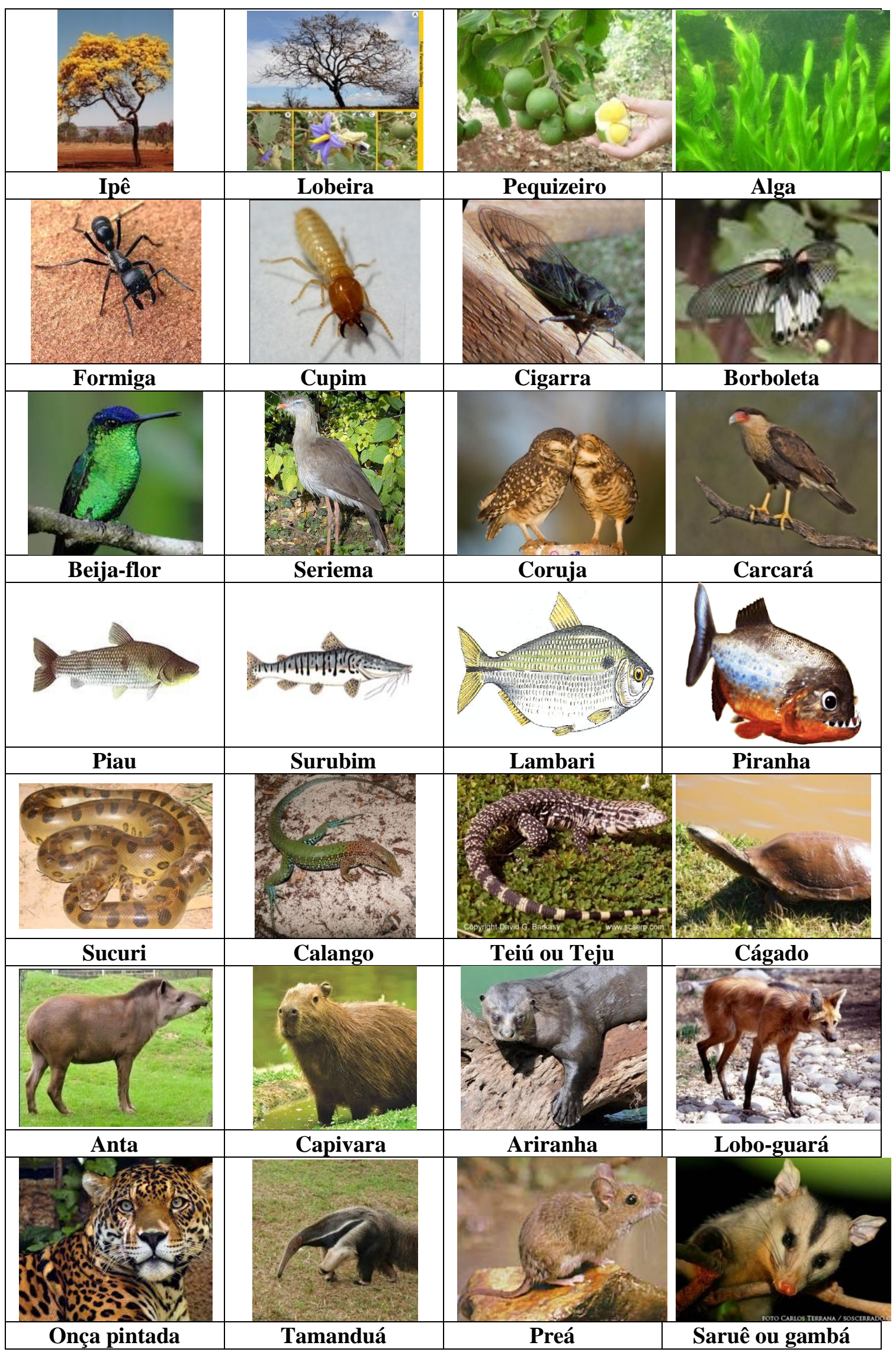




\section{Atividade 9: Entrevista final}

A entrevista final é a última atividade da nova metodologia. Os esquemas das cadeias ou teias alimentares das relações ecológicas do Cerrado que foram elaborados na atividade 8 serviram de subsídio para a realização da entrevista individual. O objetivo desta atividade foi investigar como os alunos pensaram para estabelecer as relações ecológicas e se houve aprendizagem do conceito de ecossistema.

Para a realização da atividade, foi utilizada uma sala diferente da sala habitual dos alunos. A entrevistadora os convocou voluntária e individualmente para a entrevista. A fim de nortear a entrevista, foram elaboradas algumas questões, por exemplo: Como você pensou para montar essas relações entre os seres vivos escolhidos? Você acha que montou uma cadeia alimentar ou uma teia alimentar? Qual a diferença entre elas? Você acha que seu desenho poderia representar um ecossistema? O que você entende por ecossistema? Como nós, seres humanos, interferimos no ecossistema? Além dessas questões, cada entrevista gerou questionamentos específicos e peculiares. As entrevistas foram gravadas para a análise posterior dos dados gerados.

Portanto, a nova metodologia diferencia-se do ensaio metodológico em função do tema (ecossistema), das atividades propostas na elaboração conceitual, considerando-se que algumas integraram a mediação da entrevistadora na promoção do debate e nas interações dialógicas, e ainda o uso de um desenho animado ${ }^{99}$ em vez de uma série ${ }^{100}$ de desenhos.

Sendo assim, a nova metodologia buscou desenvolver diferentes tipos de atividades, individuais ou coletivas, com o uso de imagens fixas e em movimento (desenho animado) que possibilitasse demonstrar o processo de formação de conceito à luz da teoria histórico-cultural proposta pelo psicólogo russo Vigotski.

\footnotetext{
${ }^{99}$ Com o tempo de duração de dezesseis minutos.

${ }^{100}$ Lembrando que, no ensaio metodológico, utilizou-se uma série de desenhos animados denominada de Invasão Plâncton, no qual foram exibidos quinze episódios de sete minutos cada.
} 


\section{CAPÍtULO 5}

\section{ANÁLISE E DISCUSSÃO DOS DADOS GERADOS}

O desenvolvimento dos conceitos científicos na idade escolar é, antes de tudo, uma questão prática de imensa importância - talvez até primordial - do ponto de vista das tarefas que a escola tem diante de si quando inicia a criança no sistema de conceitos científicos (VIGOTSKI, 2009, p. 241).

O emprego funcional da palavra constitui-se como meio para o desenvolvimento dos conceitos. Vigotski (2009) propõe quatro etapas do processo de elaboração do conceito: (i) processo de elaboração do conceito; (ii) processo de transferência do conceito elaborado para novos objetos; (iii) emprego do conceito no processo de livre associação; e (iv) aplicação do conceito na formação de juízos e definição de conceitos reelaborados. O complexo processo de formação de conceito envolve tanto o desenvolvimento intelectual das funções psíquicas superiores quanto a operação com conceitos na realidade.

A metodologia elaborada no presente estudo constitui-se em uma tentativa de analisar em que medida os alunos do $5^{\circ}$ ano (Anos Iniciais - Ensino Fundamental) se apropriam das informações científicas apresentadas na narrativa do desenho animado Meи corpo, meu mundo e como essas informações são articuladas na formação do conceito de ecossistema. Nos experimentos realizados por Vigotski e seus colaboradores, o intuito era "identificar" como as crianças operavam com o conceito durante todo o experimento para solucionar um problema. Na metodologia adotada, observou-se o avanço das ideias e do significado da palavra apresentadas pelos alunos durante todo o desenvolvimento do processo.

O conceito de ecossistema envolve três elementos: o conceito de ser vivo, o conceito de ser não vivo e a interdependência entre os seres vivos e não vivos. O quadro 8 a seguir apresenta as atividades desenvolvidas com os alunos e os respectivos objetivos. Vale ressaltar que a duração de cada uma das atividades propostas foi variada.

De uma maneira geral, as atividades propostas envolviam os processos psíquicos para a formação de conceitos como a compreensão, o desmembramento, a discriminação de atributos, a abstração e a síntese. Como o conceito de ecossistema envolve os conceitos (ser vivo e ser não vivo), foram propostas diferentes situações que contemplassem estes processos psíquicos e avaliassem o papel pedagógico do desenho animado na formação do conceito supracitado. 
Quadro 8. Resumo e tempo aproximado de cada atividade desenvolvida com os alunos.

\begin{tabular}{|c|c|c|}
\hline Período & Atividade & Principal objetivo \\
\hline \multirow{3}{*}{$\begin{array}{l}\text { Interação } \\
\text { (1 semana) }\end{array}$} & $\begin{array}{c}\text { Lista de seres vivos e não vivos } \\
(20 \text { minutos })\end{array}$ & $\begin{array}{l}\text { Subsidiar a seleção de imagens na } \\
\text { atividade 3.1. }\end{array}$ \\
\hline & $\begin{array}{l}\text { Roda de conversa } \\
\text { (20 minutos) }\end{array}$ & Familiarizar o uso do gravador. \\
\hline & $\begin{array}{l}\text { Entrevista sobre os seres vivos } \\
\text { (20 minutos })\end{array}$ & $\begin{array}{l}\text { Avaliar a noção que os alunos } \\
\text { possuem de ser vivo. }\end{array}$ \\
\hline \multirow{5}{*}{$\begin{array}{l}\text { Pré-exibição } \\
\text { (1 semana) }\end{array}$} & $\begin{array}{l}\text { Solicitação de desenho e texto } \\
\text { (45 minutos) }\end{array}$ & $\begin{array}{l}\text { Identificar os conceitos cotidianos } \\
\text { dos alunos sobre ecossistema. }\end{array}$ \\
\hline & $\begin{array}{l}\text { Entrevista individual } \\
\text { ( } 2 \text { horas e } 30 \text { minutos) }\end{array}$ & $\begin{array}{l}\text { Fornecer pistas do conhecimento } \\
\text { que o aluno possui sobre o tema } \\
\text { ecossistema. }\end{array}$ \\
\hline & $\begin{array}{l}\text { Seres vivos e não vivos } \\
\text { (3 horas) }\end{array}$ & $\begin{array}{l}\text { Avaliar os critérios utilizados } \\
\text { pelos alunos para classificar em } \\
\text { seres vivos e não vivos. }\end{array}$ \\
\hline & $\begin{array}{l}\text { Relações ecológicas } \\
\text { (1hora e } 30 \text { minutos) }\end{array}$ & $\begin{array}{l}\text { Perceber a interdependência entre } \\
\text { os seres vivos e não vivos. }\end{array}$ \\
\hline & $\begin{array}{l}\text { Elaboração de uma cadeia alimentar } \\
\text { (30 minutos) }\end{array}$ & $\begin{array}{l}\text { Discutir os conceitos de } \\
\text { produtores, herbívoros, carnívoros } \\
\text { e decompositores. }\end{array}$ \\
\hline \multirow{4}{*}{$\begin{array}{l}\text { Sessão de } \\
\text { Desenho } \\
\text { animado } \\
\text { (1 semana) }\end{array}$} & $\begin{array}{l}\text { Contação de história } \\
\text { (30 minutos) }\end{array}$ & $\begin{array}{l}\text { Verificar a compreensão da } \\
\text { narrativa do desenho animado. }\end{array}$ \\
\hline & $\begin{array}{c}\text { Descrição das cenas da narrativa do } \\
\text { desenho animado } \\
(30 \text { minutos })\end{array}$ & $\begin{array}{l}\text { Verificar a compreensão de fatos } \\
\text { que ocorreram na narrativa do } \\
\text { desenho animado. }\end{array}$ \\
\hline & $\begin{array}{c}\text { Debate } 1 \\
(45 \text { minutos }) \\
\end{array}$ & $\begin{array}{l}\begin{array}{l}\text { Desenvolver o } \\
\text { ecossistema. }\end{array}\end{array}$ \\
\hline & $\begin{array}{c}\text { Debate } 2 \\
(45 \text { minutos })\end{array}$ & $\begin{array}{l}\text { Discutir as ações antrópicas } \\
\text { provocadas no ecossistema. }\end{array}$ \\
\hline \multirow{3}{*}{$\begin{array}{l}\text { Pós-exibição } \\
\text { (1 semana) }\end{array}$} & $\begin{array}{c}\text { Recontar a história } \\
\text { (2 horas e 30minutos) }\end{array}$ & $\begin{array}{l}\text { Avaliar como os alunos } \\
\text { empregaram a palavra ecossistema } \\
\text { no reconto da história. }\end{array}$ \\
\hline & $\begin{array}{l}\text { Relações ecológicas do Cerrado } \\
\text { (1 hora) }\end{array}$ & $\begin{array}{l}\text { Relacionar os } \text { seres vivos do } \\
\text { Cerrado para } \\
\text { interações dialógicas da entrevista } \\
\text { final. }\end{array}$ \\
\hline & $\begin{array}{l}\text { Entrevista final } \\
\text { (3 horas) }\end{array}$ & $\begin{array}{l}\text { Avaliar a aprendizagem do } \\
\text { conceito ecossistema. }\end{array}$ \\
\hline
\end{tabular}

A proposição de diferentes situações permite ao aluno realizar diferentes processos psíquicos para a formação e elaboração de um conceito que, para Vigotski, só é possível ocorrerem função de o conceito científico fazer parte de um sistema de relações com outros conceitos. Ferreira (2009) compartilha sobre a importância da proposição de diferentes situações:

[...] é importante propor situações de aprendizagem que ativem processos e procedimentos mentais vinculados à forma abstrata do pensamento movimentar-se, à generalização de generalizações anteriormente elaboradas, 
a operações mais conscientes e voluntárias. Isso é viável em virtude de os alunos se encontrarem em estágios mais avançados do seu desenvolvimento psíquico, possibilitando o uso consciente e voluntário de todas as funções e processos mentais (FERREIRA, 2009, p.131).

Ao contrário do que supunha a antiga psicologia, na qual, para atingir os conceitos científicos, era necessário ascender à base da pirâmide de conceitos. Na psicologia vigente, ocorre um movimento em dois sentidos - concreto para abstrato e abstrato para concreto - em que o processo de formação exige uma reelaboração constante que envolve todas as funções psíquicas superiores.

Com base no aporte teórico, a análise dos dados gerados segue em três sentidos: evidências que permitam indicar variações no desenvolvimento do pensamento do aluno (tipos ou subtipos que foram identificados), o papel da mediação pedagógica na tomada de consciência e, por último, o desenvolvimento do significado da palavra durante todo o experimento. Em função da quantidade de dados gerados, optou-se por abordar as questões que foram mais relevantes durante a execução do estudo para a discussão da formação de conceito de ecossistema e o papel pedagógico do desenho animado nesse processo.

No período de interação com os alunos, optou-se por desenvolver os conceitos de ser vivo e não vivo desde as atividades de interação para subsidiar o planejamento das atividades posteriores, o que possibilitou a distinção dos atributos, o contato com o conceito ecossistema por meio do desenho animado e a generalização até atingir ou não a conceptualização.

\subsection{Atividades realizadas com os alunos}

\subsubsection{Períodos de observação e interação}

Os períodos compreendem os espaços de tempo (dias) entre um determinado número de atividades que foram desenvolvidas com os alunos. Ao total, obtiveram-se quatro períodos: interação, pré-exibição, sessão e pós-exibição. O primeiro período permitiu obter as informações sobre a escola e o cotidiano dos alunos a partir do primeiro contato com a direção, com a equipe pedagógica e com a professora responsável pela turma.

Lembrando que os onze alunos participantes da pesquisa pertencem à faixa etária de dez a treze anos de idade e a turma é composta por seis meninos e nove meninas, totalizando quinze alunos. Os $5^{\circ}$ anos funcionam no período vespertino. A escola ${ }^{101}$ caracteriza-se por ser uma instituição comprometida com o desenvolvimento integral do aluno, com a execução de

\footnotetext{
${ }^{101}$ As informações foram obtidas no Projeto Político e Pedagógico da escola, que encontram-se disponível em:〈http://sumtec.se.df.gov>. Acesso: em 1 nov. 2014.
} 
projetos voltados para a formação moral e cívica, articulados com os temas transversais dos Parâmetros Curriculares Nacionais como o meio ambiente e a orientação sexual.

No primeiro dia do período de observação, ao contrário de outras escolas públicas visitadas pela entrevistadora, os alunos se reúnem com outras turmas no pátio da escola para fazerem uma oração antes de entrarem para a sala de aula. Especialmente na segunda-feira, um aluno é convidado a cantar o hino nacional enquanto outros dois seguram a bandeira do Brasil. A escola possui uma abordagem voltada para a questão tanto espiritual quanto aos valores morais e cívicos.

Após os alunos se dirigirem para a sala de aula, a professora iniciou a aula perguntando sobre o final de semana dos alunos e retomou o tema drogas em função da visita realizada na semana anterior ao Museu de Drogas da Polícia Civil do Distrito Federal e ao Hospital Sarah Kubitschek (sede Brasília), onde assistiram à palestra do Programa de Educação e Prevenção de Acidentes.

A relação entre a professora e os alunos é cordial e estes demonstravam carinho e respeito por ela. No período em que a pesquisa foi desenvolvida, a escola desenvolvia um projeto sobre reciclagem e outro sobre alimentação saudável, que contaram com a parceria do SLU $^{102}$ e do SESC ${ }^{103}$, respectivamente.

A professora apresentou a entrevistadora aos alunos, entregou-se o TCLE e explicouse sobre a sua importância. Os alunos comentaram sobre as suas experiências com gravadores de celulares e demonstraram ser participativos nesse contato inicial. Na perspectiva teórica histórico-cultural, a interação social tem um papel relevante no desenvolvimento humano.

No processo de desenvolvimento histórico, o homem social modifica os modos e procedimentos de sua conduta, transforma suas inclinações naturais e funcionais, elabora e cria novas formas de comportamento especificamente culturais (VIGOTSKY, 1997, p. 19, tradução nossa).

Esta interação social pôde ser identificada em diversas situações no ambiente escolar. Os alunos foram solicitados pela professora para redigirem uma redação com o seguinte título: Por que eu não quero usar drogas? Como esta atividade foi realizada em uma segundafeira, os alunos estavam bastante agitados e discutiam sobre o aniversário de uma colega que havia sido disponibilizado em uma rede social na internet. Além disso, eles também estavam

\footnotetext{
102 Serviço de Limpeza Urbana do Distrito Federal.

${ }^{103}$ Serviço Social do Comércio.
} 
entretidos com a produção de pulseiras de ligas de cabelo de elástico colorido. Logo, a professora os repreendeu para que retomassem a atividade.

Após a devolução do TCLE no dia seguinte, a entrevistadora constatou que todos os responsáveis pelos alunos consentiram a participação deles no presente estudo. Sendo assim, tornou-se possível iniciar as atividades de interação que serviriam de subsídio para a elaboração de situações de aprendizagem na fase de pré-exibição do desenho animado.

Os alunos foram solicitados a elaborar uma lista de seres vivos e não vivos que posteriormente subsidiaria a seleção das imagens fixas a serem utilizadas em atividade posteriores (Atividade 3.1). Cada aluno listou dez seres vivos e dez seres não vivos. Ao total, listaram-se quarenta e nove seres vivos com a seguinte distribuição: reino Plantae (4) e do reino Animalia (45), entre eles, do filo Cnidaria (1), do filo Molusca (1), do filo Arthropoda (4) e do filo Cordado (39). Os nomes repetidos dos seres vivos foram desconsiderados.

A seguir, o gráfico 1 apresenta o nome do ser vivo e o número de vezes que foi citado. Os seres vivos mais citados foram o leão (10 vezes), seguido pelo cachorro (9 vezes) e, por último, o elefante, o gato e a cobra, que foram citados sete vezes cada. Além disso, os seres vivos que habitam o continente africano como a girafa, a zebra e o tigre também apresentaram um número significativo e foram citados cinco vezes pelos dois primeiros e seis vezes pelo último.

O gráfico $2^{104}$ apresenta o agrupamento dos seres vivos de acordo com a classe pertencente, conforme a classificação taxonômica vigente: Anfíbios (1), Aves (4), Cifozoários (1), Crustáceos (1), Gastrópodes (1), Insetos (3), Mamíferos (28), Peixes (2) e Répteis (4). Dos 49 seres vivos citados, 28 deles eram mamíferos e representaram a maioria dos seres vivos agrupados por classe, seguidos pelas aves (4) e pelos insetos (3).

A partir dos resultados gerados, pode-se perceber a preferência por animais vertebrados de grande porte em comparação aos animais invertebrados. Apesar de estes últimos serem representados por quatro classes (cifozoários, crustáceos, gastrópodes e insetos) e os vertebrados somente por uma classe a mais (anfíbios, aves, mamíferos, peixes e répteis).

${ }^{104}$ Vale ressaltar que os agrupamentos apresentados nos gráficos 2 e 4 foram elaborados pela entrevistadora. 
Gráfico 1. Nomes dos seres vivos e número de vezes em que foram citados pelos alunos.

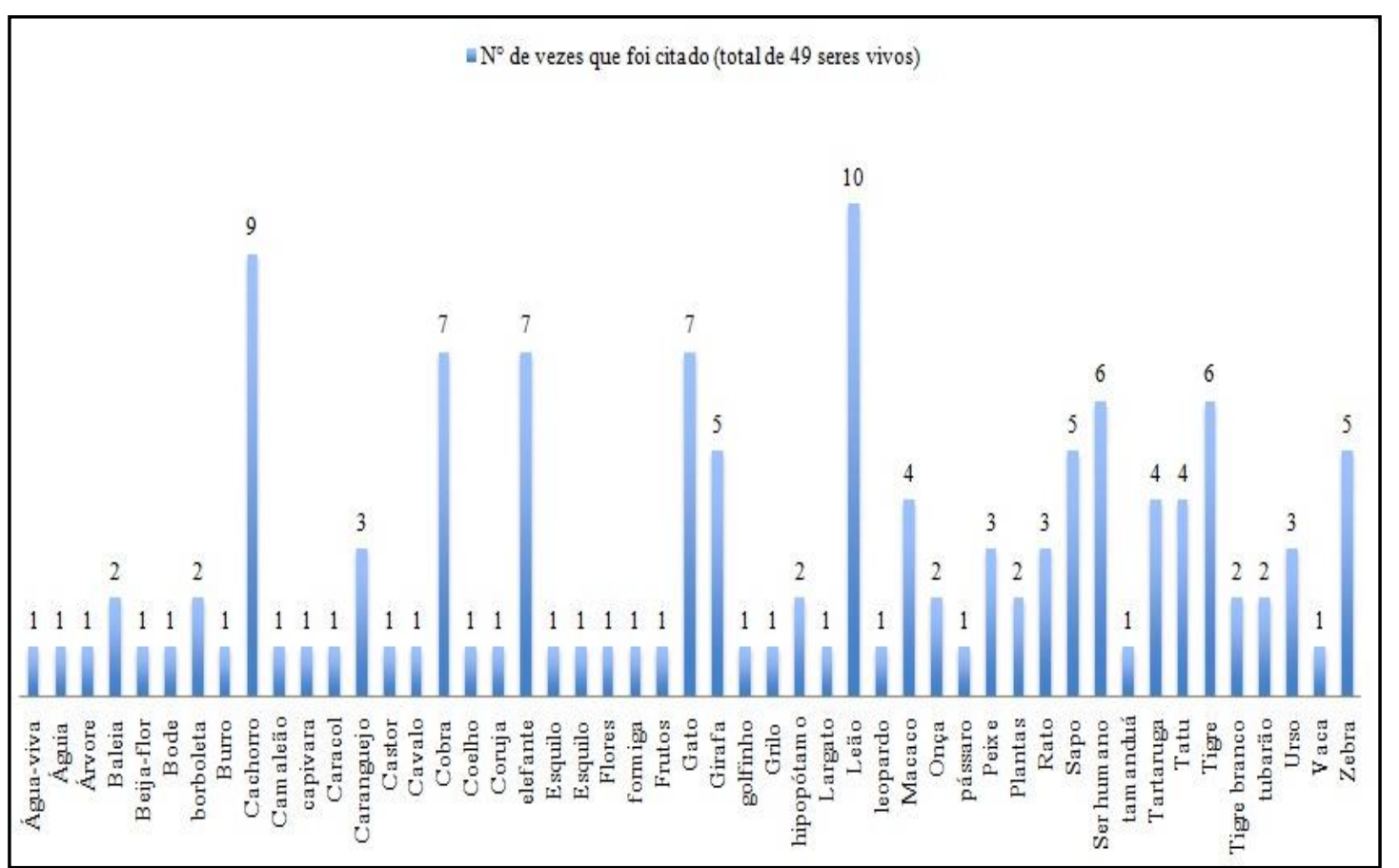

Gráfico 2. Agrupamento por classe dos seres vivos citados pelos alunos.

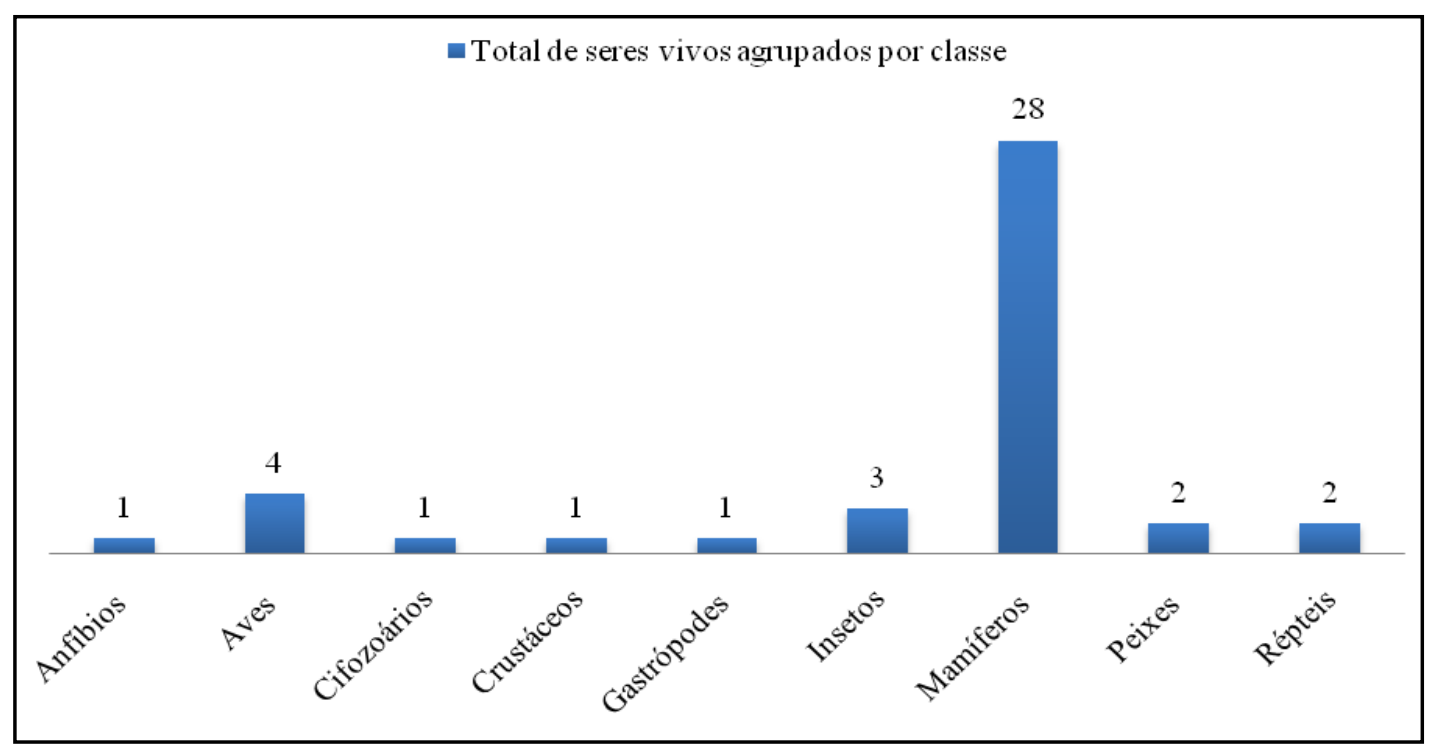

Em relação aos seres não vivos, os alunos listaram, ao total, cinquenta e sete itens. O gráfico 3, a seguir, apresenta o nome do ser não vivo e o número de vezes que foi citado. A caixa foi o objeto mais citado (11 vezes), seguido do lápis (10 vezes) e, por último, a caneta (9 vezes). A maioria dos objetos que foram citados mais de três vezes estava relacionado com os materiais escolares utilizados na sala de aula como, por exemplo, o estojo, a cola, a borracha e o caderno. Assim como o procedimento anterior, os nomes repetidos foram desconsiderados. 
Gráfico 3. Nomes dos seres não vivos citados pelos alunos.

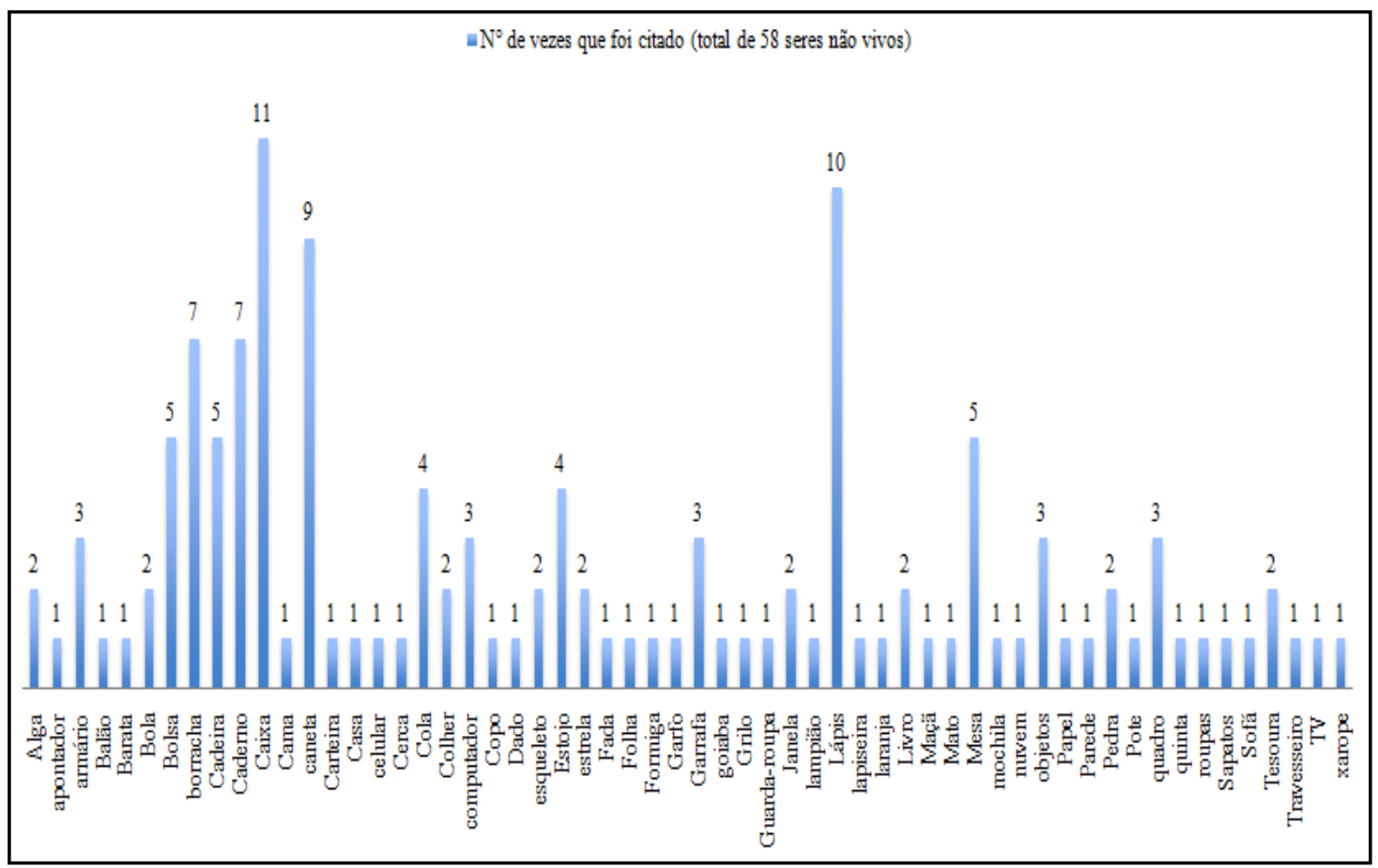

O gráfico 4 a seguir apresenta os seres não vivos que foram agrupados em: astro (1); minerais (2);objetos (46); e, inclusive, seres vivos (8), estes últimos incluíam algas, frutas, insetos e plantas, que demonstra ainda uma certa confusão em definir o que é ser vivo e ser não vivo. Os objetos foram os elementos mais citados (46 vezes) visto que a maioria deles compõem o ambiente da sala de aula (armário, cadeira, mesa, etc.), seguido dos seres vivos (8 vezes, e, por último, os minerais.

Gráfico 4. Agrupamento de elementos considerados seres não vivos pelos alunos.

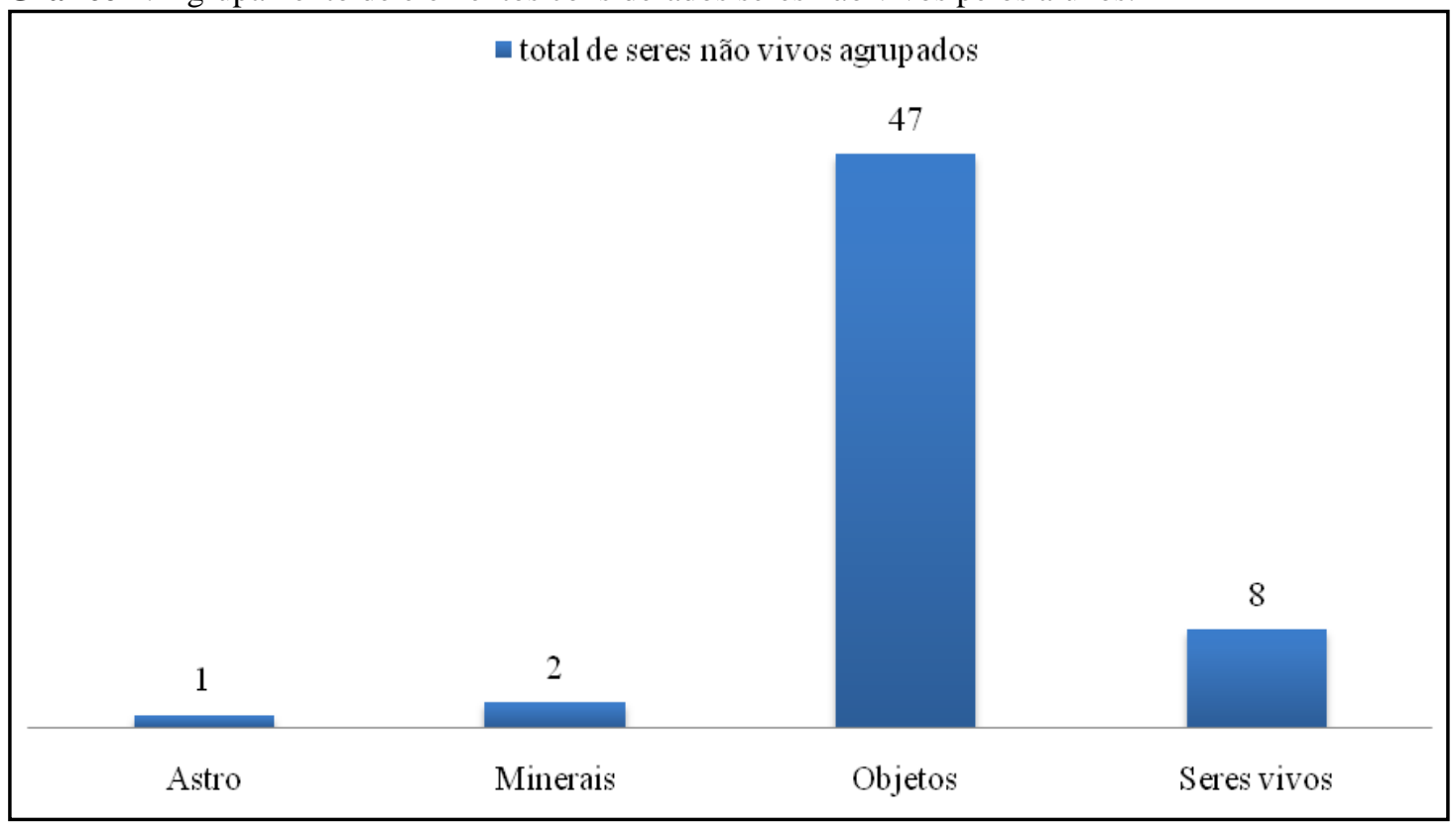


Posteriormente, solicitou-se aos alunos a escolha de um exemplar de cada (ser vivo e ser não vivo) da lista elaborada por eles. Para a compilação dos dados, cada aluno relacionou os exemplares escolhidos na lousa branca conforme apresentado no quadro 9. Pode-se notar que os mamíferos (cachorro, cavalo, girafa, leão e macaco) foram os mais citados na lista compilada assim como no gráfico 2 citado anteriormente. Com relação aos seres não vivos, prevaleceu os objetos referentes aos materiais escolares como borracha, caderno, caneta e cola assim como observado no gráfico 4 .

Quadro 9. Lista de seres vivos e não vivos compilados na lousa branca da sala de aula.

\begin{tabular}{|c|c|}
\hline Seres vivos & Seres não vivos \\
\hline Aracnídeos & Armário \\
\hline Beija-flor & Bola \\
\hline Borboleta & Bolsa \\
\hline Cachorro & Borracha \\
\hline Camaleão & Caderno \\
\hline Caracol & Caneta \\
\hline Caranguejo & Cola \\
\hline Cavalo & Computadores \\
\hline Cobra & Estojo \\
\hline Girafa & Faixa \\
\hline Leão & Lápis \\
\hline Macaco & Objetos \\
\hline Peixe & Pedra \\
\hline Tigre branco & Perfume \\
\hline
\end{tabular}

Após a compilação da lista, os alunos foram convidados a participar da roda de conversa, que teve o intuito de permitir que a entrevistadora interagisse com os alunos. A conversa iniciou-se com um comentário sobre as funções do gravador de voz e os profissionais que o utilizavam. Os alunos citaram os repórteres e os jornalistas. Quando os alunos foram questionados sobre gostar de Ciências, a maioria respondeu positivamente. Os temas que eles mais gostam são os animais, as células, o ciclo da água, o corpo humano, as experiências e os seres vivos.

A entrevistadora pediu que os alunos escolhessem um ser vivo relacionado no quadro branco. A partir da escolha, o tigre branco, a entrevistadora pintou com giz de cera um molde de máscara de cartolina que representava este ser vivo para explicar a próxima atividade que seria a confecção de uma máscara. Enquanto a entrevistadora coloria a máscara, a conversa continuou. Um dos alunos comentou sobre o episódio ${ }^{105}$ em que o menino teve o braço dilacerado por um tigre e discutiu-se sobre de quem era a responsabilidade, do pai que o

${ }^{105}$ Em julho de 2014, um menino teve o braço dilacerado por um tigre no zoológico de Cascavel, Santa Catarina. 
acompanhava ou dos funcionários do zoológico que permitiram que o garoto entrasse na área restrita aos animais e as opiniões expressadas entre os alunos divergiram. A roda de conversa teve a duração de vinte e um minutos.

Retomando a atividade proposta, a maioria de os alunos escolheu os vertebrados (mamíferos) de grande porte como o leão, a onça e a girafa, que podem ser vistos no zoológico de Brasília, para confeccionar a máscara de cartolina. Outros alunos escolheram o gato, o sapo e o macaco. O único invertebrado escolhido foi um caracol ${ }^{106}$. Apesar de os alunos não terem ido ao Zoológico no ano em que o estudo foi desenvolvido, eles disseram que vão com frequência e também foram com a escola em anos anteriores. A seguir, na figura 29, alguns exemplos das máscaras que foram confeccionadas.

Conforme os alunos foram terminando de colorir as suas máscaras, as duplas foram sendo formadas e a entrevistadora os convocava para gravar a atividade, a brincadeira Entrevista sobre os seres vivos ${ }^{107}$. As propostas desta atividade foram possibilitar que os alunos interagissem com o gravador (principal instrumento da pesquisa) e avaliar a noção que os alunos possuíam sobre seres vivos.

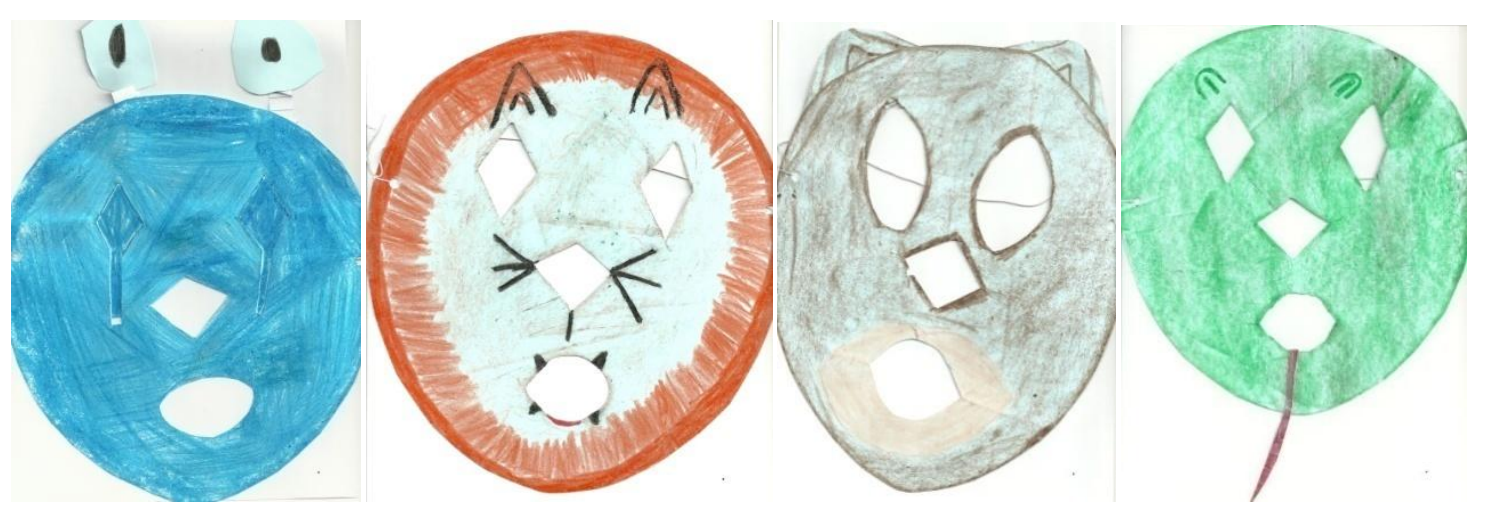

Figura 30. Exemplos de máscaras confeccionadas pelos alunos. Caracol, leão, macaco e sapo, respectivamente.

As perguntas elaboradas pelos alunos estavam relacionadas a questões antropomórficas $^{108}$ de cunho afetivo, estético, por estarem representando um animal, e também de preferências quanto à alimentação, por exemplo: Você tem família? Você tem

${ }^{106} \mathrm{O}$ aluno justificou a escolha do caracol "Gary” por ser o animal de estimação do seu personagem de desenho animado preferido, Bob Esponja, Calça quadrada.

${ }^{107}$ Nesta brincadeira, os alunos foram solicitados a realizar as seguintes tarefas: (i) escolher um ser vivo da lista elaborada anteriormente e compilada no quadro branco; (ii) confeccionar uma máscara que representasse o ser vivo escolhido; (iii) Escolher um colega para trabalhar em dupla; (iv) elaborar cinco perguntas que um ser vivo faria para o outro, entre elas, um deveria citar um ser não vivo elencado na lista elaborada; e (v) proceder uma entrevista utilizando as perguntas elaboradas e o gravador.

${ }^{108}$ De acordo com Houaiss (2009), antropomórfico é descrito ou concebido sob uma forma humana ou com atributos humanos. 
amigos? Você se acha bonita? O que você gosta de fazer? O que você gosta de comer? Qual a sua comida preferida?

O local de origem e a moradia também integraram as perguntas para o outro ser vivo. As perguntas foram do tipo: Onde você mora? Onde você nasceu? De onde você veio? Onde você gosta de morar? Cada entrevista teve a duração média de um a três minutos.

A seguir, a primeira entrevista entre os alunos que escolheram o leão (A3M12) ${ }^{109}$ e o sapo (A6F11), transcrita na íntegra, exemplifica as perguntas elaboradas pelos alunos.

Dupla 1 - Leão (A3M12), Sapo (A6F11) e Entrevistadora (E)

A6F11: Eu sou o sapo. Qual o seu habitat natural?

A3M12: O meu habitat natural é morar na selva.

A6F11: Você têm calçados?

A3M12: Tenho!

A6F11: Você gosta de comer biscoitos do pote ou do pacote?

A3M12: Do pacote!

A6F11: Qual é a sua comida preferida?

A3M12: A minha comida preferida é carne.

E: Pode perguntar para ela.

A3M12: Você é chata assim ou não?

A6F11: Não!

A3M12: Você gosta de morar aonde?

A6F11: Deixa eu ver! Prefiro matos, lagoas e eu gosto de ficar pulando na vitória-régia.

A3M12: Você tem família?

A6F11: Sim.

A3M12: Você é legal?

A6F11: Sim.

A3M12: Você tem casa?

A6F11: Sim.

Pôde-se observar nas entrevistas que as respostas referentes às questões sobre a preferência alimentar têm apresentado algumas representações quanto a determinados animais como o macaco gostar de bananas, o rato preferir queijo e o caracol comer ração para caracol, estes dois últimos são reforçados constantemente por desenhos animados transmitidos por canais televisivos, por exemplo, Tom e Jerry, em que o rato aparece segurando o queijo suíço.

De acordo com Giordan e De Vecchi (1996), os modelos explicativos apresentados inicialmente na área de Biologia podem ser antropomórficos:

${ }^{109}$ Para a identificação dos alunos, optou-se por estabelecer um código alfanumérico composto pela letra A (aluno) e o respectivo número, a letra inicial $\mathrm{F}$ ou $\mathrm{M}$ referente ao sexo da criança (F para feminino e $\mathrm{M}$ para masculino) e, por último, a idade. Então, por exemplo, o código A3M12 significa que é o aluno A3 do sexo masculino, dedoze anos. 
[...] por exemplo, se um animal carnívoro come carne, é porque 'prefere' a carne aos legumes... 'assim como a gente, que o bife ao espinafre; ou seja, a gente pode forçá-lo'. Uma criança falando em 'carnívoro', não necessariamente integrou o conceito de regime alimentar. Essa noção e a concepção antropomórfica que precede podem até seguir caminhos paralelos sem jamais se unirem (GIORDAN; DE VECCHI, 1996, p. 92).

Nos estudos de Vygotsky e Luria sobre a história do comportamento do macaco, do homem e da criança, os autores discutiram uma ideia incorreta sobre o fato de a criança ser considerada como um pequeno adulto e apresentam a seguinte explicação para a atribuição de características antropomórficas:

O fato é que o modo mais simples de julgar os objetos e suas leis é por analogia consigo próprio ('antropomorficamente'); o homem primitivo atribuía seus próprios traços característicos até mesmo a animais e plantas. Ele dotava todo o seu ambiente de seus próprios traços, com sentimentos de alegria e tristeza; achava que as plantas e a natureza inanimada possuíam mente, desejos e vontade; comunicava-se com elas como se fossem com semelhantes seus. Sem dúvida, o homem primitivo sempre tratou a criança como seu duplo, atribuindo-lhes todas as características de adulto que conhecia por experiência pessoal (VYGOTSKY; LURIA, 1996, p. 152).

Esses traços do comportamento do adulto podem ter se estendido ao comportamento da criança ao longo do desenvolvimento histórico-cultural na evolução do homem primitivo ao homem cultural moderno, tanto na evolução biológica quanto no desenvolvimento da espécie humana (filogênese) e no desenvolvimento individual (ontogênese). Esse fato pode constituir-se em uma explicação para as características antropomórficas atribuídas aos seres vivos e apresentadas pelos alunos nesta atividade.

Apesar das questões serem do tipo antropomórfico, de uma maneira geral, as respostas dos alunos ${ }^{110}$ foram coerentes com o habitat, a alimentação e "o modo de vida" do ser vivo em questão, como mostra o trecho da entrevista entre o aluno A1F12 e o aluno A2F11, a seguir:
A1F12: Como é o seu nome?
A2F11: Leão
A1F12: Onde você nasceu?
A2F11: Na África
A1F12: Você gosta de comer o quê?
A2F11: Carne
A1F12: Qual tipo de carne?

\footnotetext{
110 Para a análise dos dados transcritos, foram consideradas somente as perguntas dos alunos participantes porque, até esse momento, os alunos não efetivos ainda não haviam sido eliminados no período inicial da pesquisa.
} 
A2F11: Zebra, de veado, de porco, um monte de carne aí.

A1F12: Você dorme aonde?

A2F11: No chão.

Quanto ao objetivo da atividade, as entrevistas sobre os seres vivos permitiram aos alunos, posteriormente, escutarem a sua voz gravada. Eles chegaram à conclusão de que algumas ficam diferentes, sendo que outros perceberam que a voz "saiu baixa", de acordo com as palavras deles.

\section{(b) Atividades pré-exibição}

\section{(b.1) Atividade 1: Solicitação de desenho e texto}

A palavra ecossistema foi escrita no quadro branco em letras garrafais e foi solicitada aos alunos a elaboração de um desenho para que eles representassem um ecossistema. Após a confecção do desenho, solicitou-se novamente aos alunos que redigissem um texto no verso da folha para explicitar seus conceitos cotidianos sobre o tema ecossistema.

A elaboração tanto do desenho quanto do texto possibilitaria a criação de situações dialógicas durante a atividade posterior, a entrevista individual. Os desenhos elaborados foram coerentes com as definições propostas pelos alunos. Estas primeiras ideias sobre o tema ecossistema apresentaram-se bastante diversas, como: avião perdido (A3M12); máquina de reciclar (A10F10); museu de coisas sobre a terra, o sol e a lua (A2F11); natureza e vida (A1F12, A5M10, A6F11); nuvem cheia de água (A11F12); pessoa gritando (eco) (A8M10); programa para ajudar o meio ambiente (A7F11); tratamento de água (A9F11); e sistema ecológico (A4M11).

O quadro 10, a seguir, apresenta os dados gerados na atividade 1, desenho e texto, respectivamente. 
Quadro 10. Compilação dos dados gerados na Atividade 1.

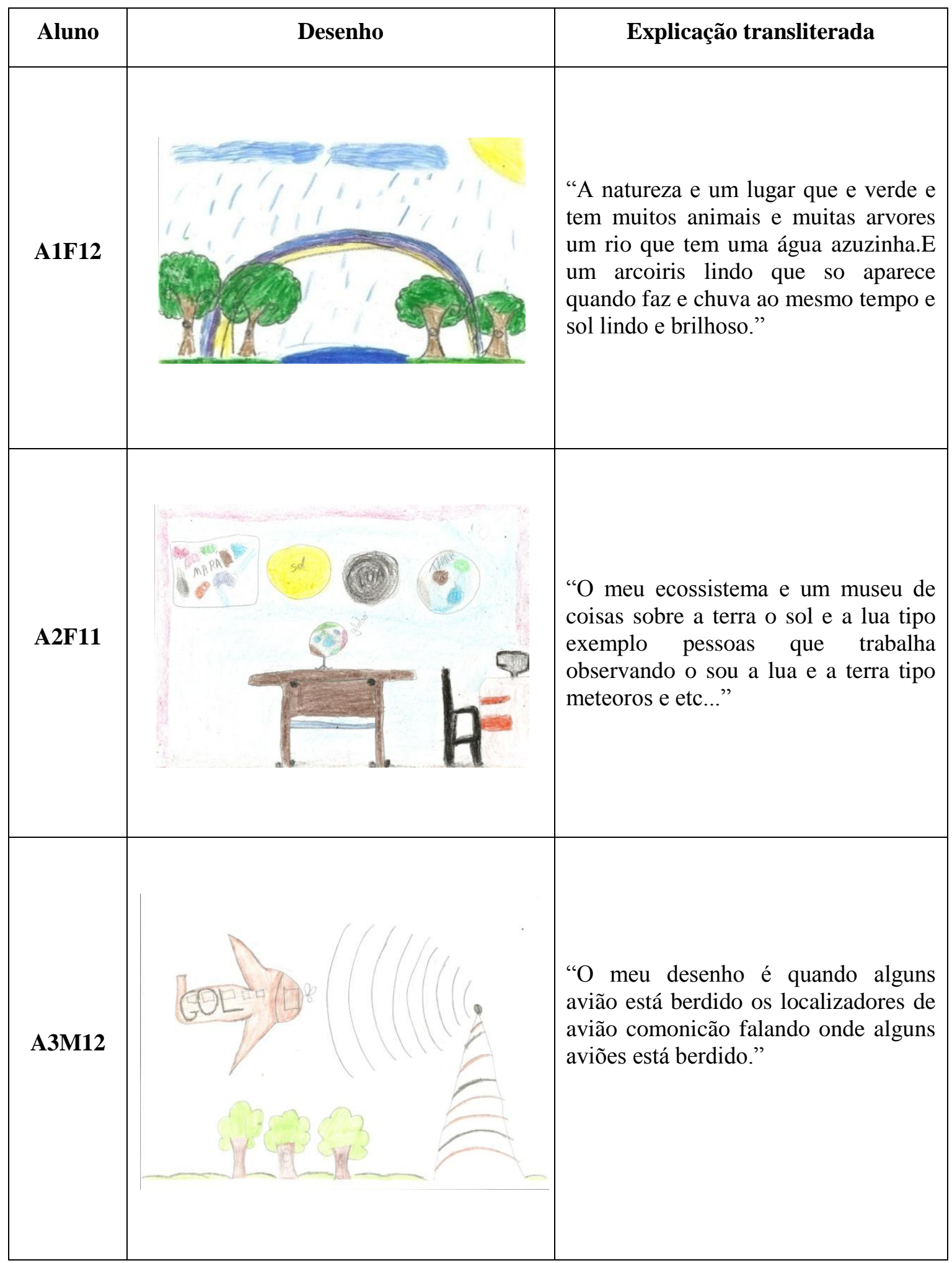




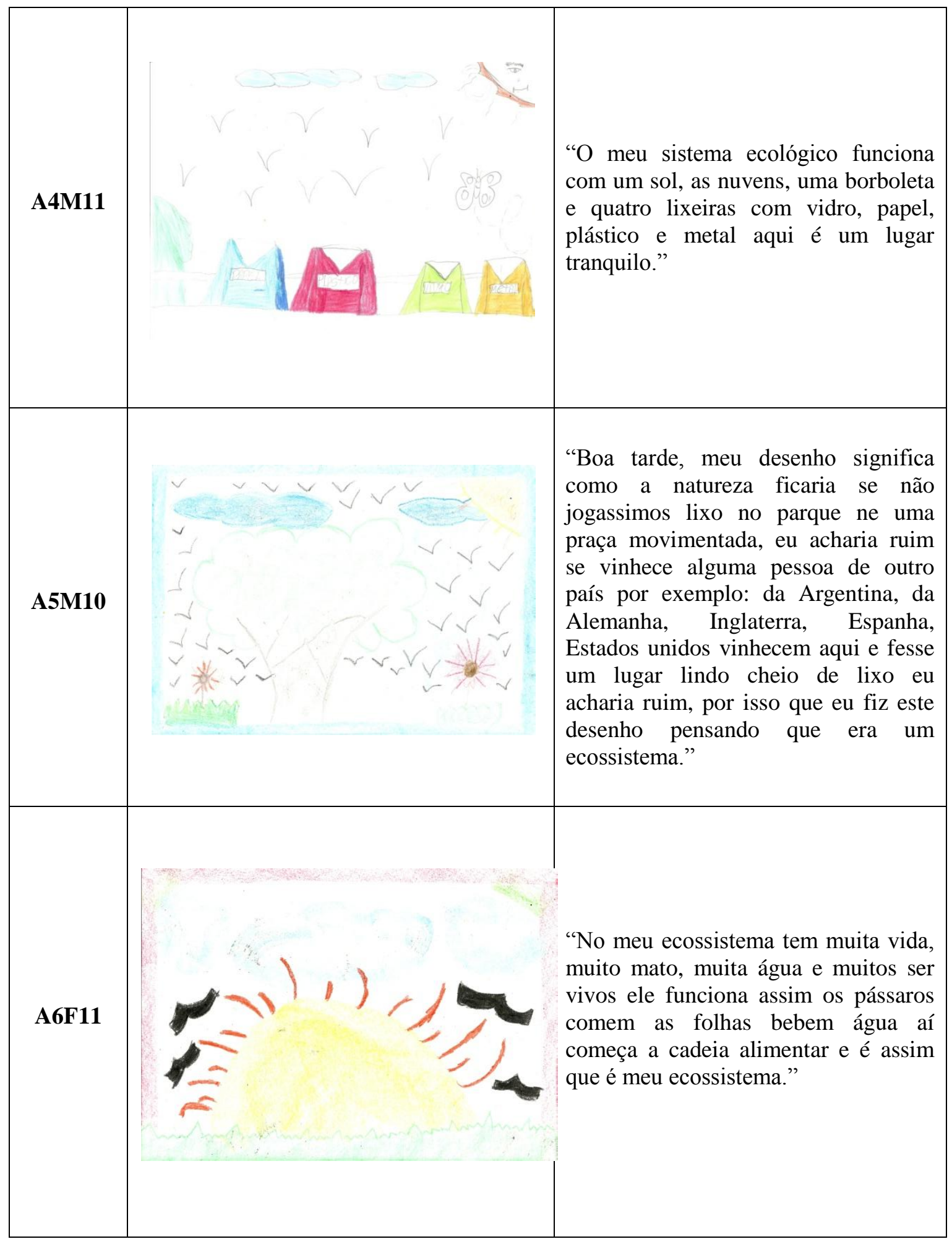




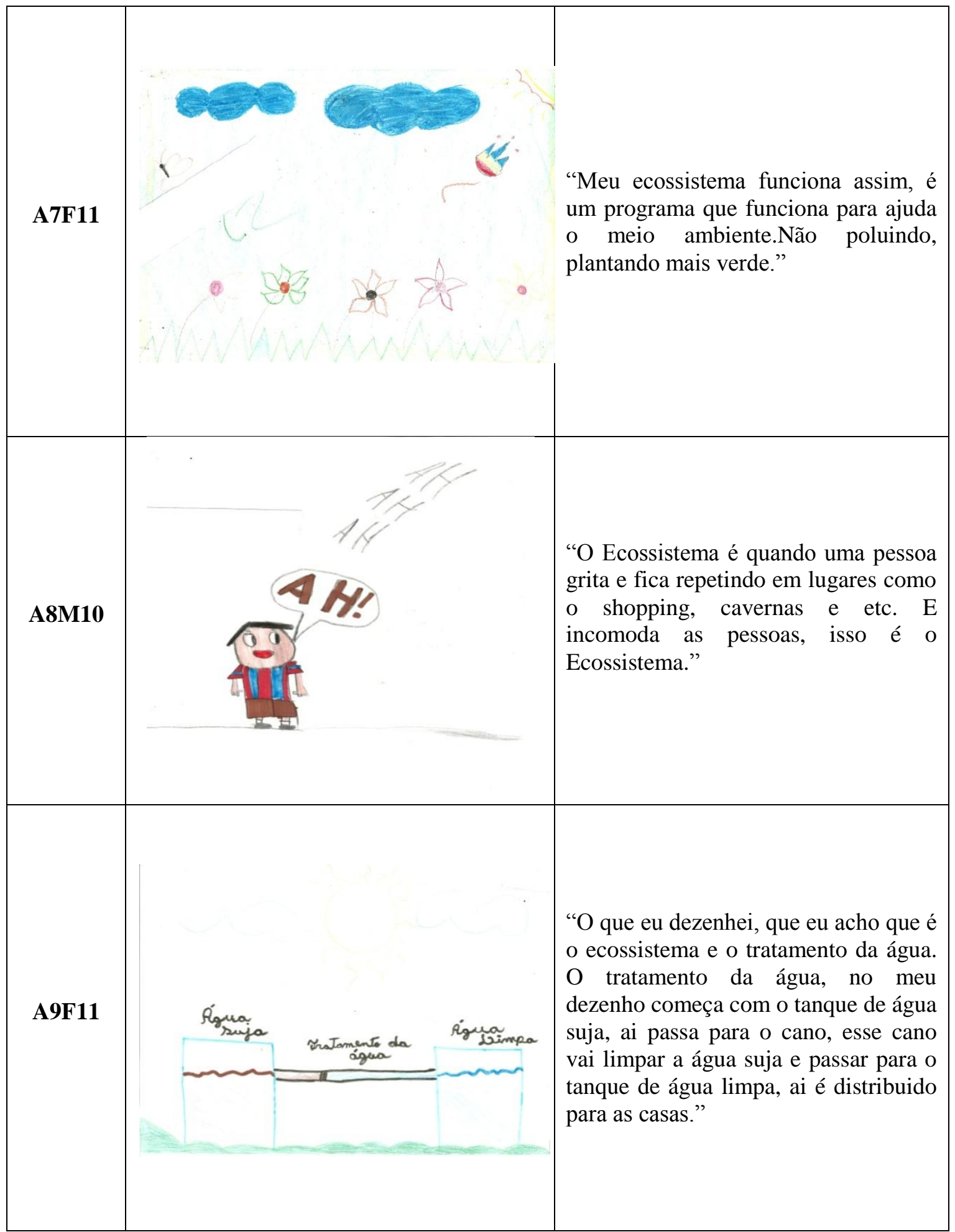




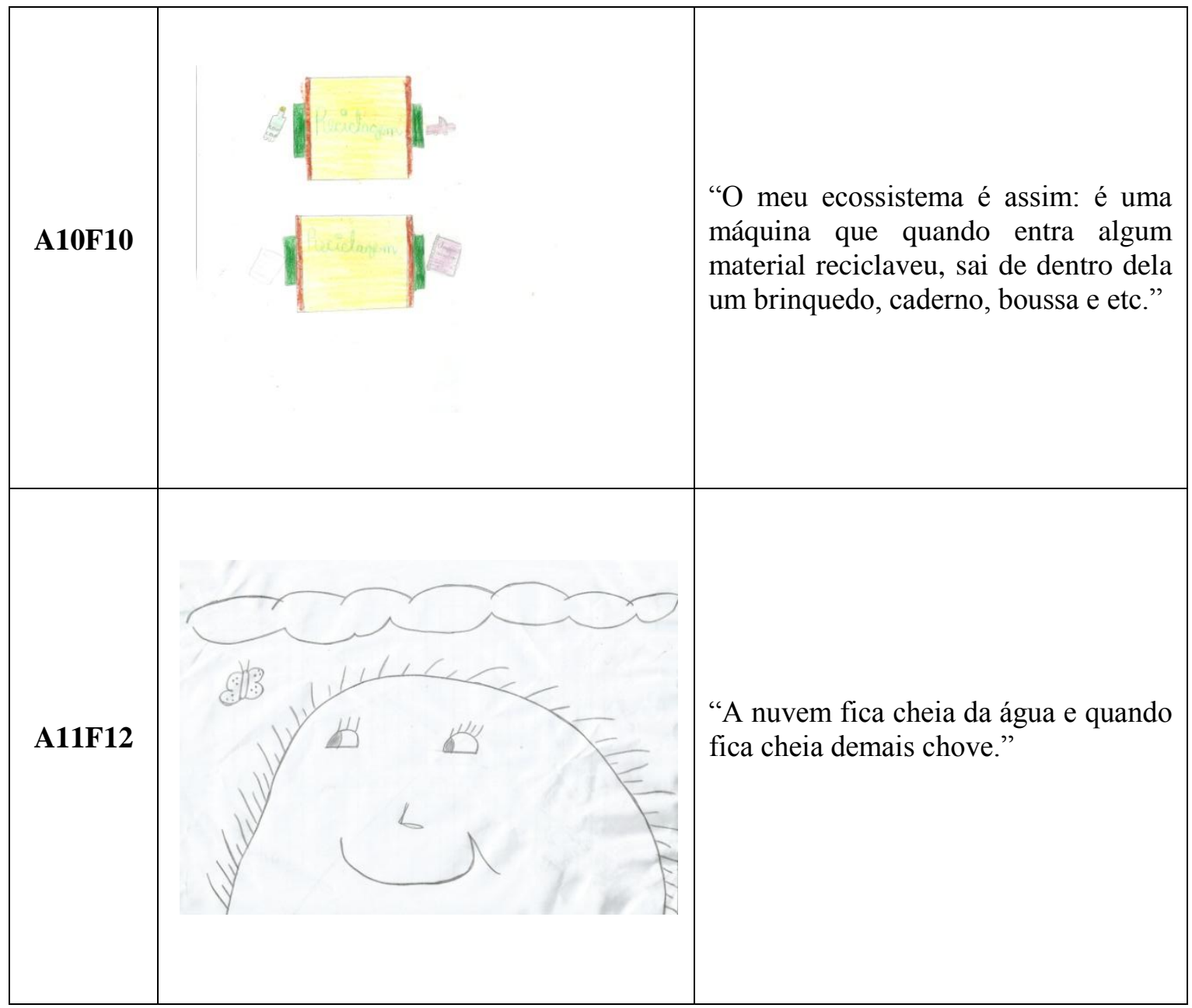

Os textos no verso dos desenhos, transliterados ${ }^{111}$ na íntegra, revelaram inicialmente diferentes conceitos cotidianos acerca da palavra ecossistema, que abarcam os seguintes temas: eco no sentido do som de uma palavra ou frase (reflexão de uma onda sonora por uma superfície ou objeto); ideias relacionadas à reciclagem; lugar de pesquisa; programa para ajudar o meio ambiente; relação com o ambiente, natureza ou paisagem; sistema de radar de avião; sistema ecológico; e tratamento da água.

Em relação ao comando da questão, o que é ecossistema e como ele funciona, dos onze alunos, cinco (A1F12, A2F11, A5M10, A8M10 e A11F12) explicaram o que seria para eles um ecossistema, quatro explicaram somente o funcionamento (A3M12, A4M11, A6F11 e A7F11) do que eles propuseram a ser um ecossistema no desenho, e, por último, dois alunos (A9F11 e A10F10) explicaram o que é um ecossistema e o seu funcionamento. Para o aluno A9F11, o ecossistema se limita ao tratamento da água, ele explica o funcionamento por meio das etapas do processo de tratamento de água "começa com o tanque de água suja, ai passa

${ }^{111}$ De acordo com Houaiss (2009), transliterar é escrever com um sistema de caracteres (algo escrito com outro). 
para o cano, esse cano vai limpar a água suja e passar para o tanque de água limpa, ai é distribuído para as casas" (A9F11).

A maioria dos alunos (oito) optou por elaborar os desenhos em um campo visual integral que apresenta uma paisagem composta de elementos naturais como as flores, as nuvens, os pássaros e o sol. Para Vigotski (1998), a linguagem desempenha um papel "surpreendente" na percepção ao longo do desenvolvimento infantil, "elementos independentes num campo visual são percebidos simultaneamente; nesse sentido, a percepção visual é integral" (p. 23, grifo do autor). A partir do desenvolvimento da percepção, a criança que identificava anteriormente os elementos isolados passa a percebê-los em um campo visual integral:

O que a criança antes percebera como um grande número de fragmentos acidentados, isolados e flutuantes (temos impressão semelhante quando examinamos um mapa desconhecido, quando caminhamos por uma rua de uma cidade estranha ou quando estudamos uma lição desconhecida) começa agora a ser percebido como uma série de quadros completos. Pelo fato de as "imagens visuais" permanecerem na mente da criança, a experiência anterior funde-se com os estímulos atuais e o mundo adquire um caráter integral (VYGOTSKY; LURIA, 1996, p. 159).

Nos outros desenhos, pode-se observar também que eles foram elaborados dentro de um campo visual integral em função dos elementos escolhidos para compor um cenário, demonstrando uma percepção globalizada do ambiente imaginado para a palavra ecossistema.

\section{(b.2) Atividade 2: Entrevista individual sobre os desenhos produzidos}

Os desenhos e os textos produzidos na atividade anterior foram utilizados para a realização da entrevista individual e semiestruturada que tinha como objetivo fornecer pistas sobre o conhecimento dos alunos a respeito do ecossistema. Estas entrevistas individuais duraram em média de dez a vinte minutos. Os questionamentos iniciais caracterizavam-se por perguntas do tipo: O que você pensou quando fez esse desenho? Tenta me explicar? Você pode explicar como ele funciona? Qual é a relação entre os elementos do seu desenho?

De uma maneira geral, os alunos reafirmaram as explicações propostas apresentadas na atividade escrita sobre o tema ecossistema desenvolvido na atividade 1 (ambiente ou natureza, eco, lugar de pesquisa, programa para ajudar o meio ambiente, reciclagem, sistema de radar de avião, sistema ecológico e tratamento de água). Por exemplo, a transcrição do trecho da entrevista individual do aluno A3M12, que citou o eco ao explicar o funcionamento do ecossistema: 
E: Então, o que é sistema para você?

A3M12: Acho que é isso. Não é?

E: Você está me perguntando?

A3M12: É sistema?

E: O sistema do avião pode ser. Então explica para mim, por que você colocou as árvores?

A3M12: Para falar que ele estava em um lugar cheio de árvore. Que ele estava perdido.

E: Então quer dizer que toda vez que um avião está perdido, ele vai utilizar o seu ecossistema?

A3M12: Esse negócio aqui de "Ecooo, ecooo, ecooo". (Nesse momento, o aluno aponta para os traços dos desenho que ele indica ser o eco.)

E: Então isso aqui seria o eco e o avião seria o quê?

A3M12: O que está ouvindo.

E: Mas como ele ouve? Me explica.

A3M12: Acho que dentro deles tem uma coisa assim. Um rádio que, se ele fala aqui, o... Esqueci o nome.

Somente o aluno A6F11 explicou que ecossistema era o sistema ecológico, mas, apesar de a definição se aproximar do conceito científico, o aluno não soube expressar o significado da palavra. Para Luria (1994c, p. 20), o significado da palavra "é a capacidade de analisar o objeto, distinguir nele as propriedades essenciais e relacioná-lo a determinadas categorias".

De acordo com Vigotski (2009, p.265), o contato inicial com a palavra, nesse caso, ecossistema, inicia o processo de formação de conceitos quando "a criança assimila pela primeira vez um significado ou termo novo para ela, que é veículo de conceito científico”. Para o autor, a afirmativa constitui-se na lei geral do desenvolvimento dos significados das palavras tanto para os conceitos cotidianos quanto para os científicos.

Outras observações pertinentes são referentes à tentativa, por parte dos alunos, de explicar os termos citados no decorrer da entrevista sobre os desenhos elaborados e as justificativas apresentadas, por exemplo, uns porque não lembraram o que pensaram (A2F11, A7F11, A11F12), outros porque acharam bonito (A1F12 - "porque eu gosto de fazer umas coisas assim porque fica bonito assim" - e A5M10 - "a nuvem eu fiz só para deixar o desenho mais bonito"), e alguns expressaram dúvida e confusão dos termos e/ou definições referentes à tentativa de explicar as relações de alimentação da borboleta com a sua coloração (A4M11 - "se ela come pedaço da maçã, ervilha, papel, tipo uma folhinha, ela, no outro dia está verde, vermelha”). 


\section{Atividade 3: Seres vivos, seres não vivos e relações ecológicas}

\subsection{Seres vivos e não vivos}

Para a formação do conceito ecossistema, seria necessária a discriminação de três atributos do conceito: o conceito de ser vivo, o conceito de ser não vivo e a interdependência entre eles. Para isso, elaborou-se a atividade com o uso de imagens fixas para identificá-las, separá-las em dois grupos (seres vivos e não vivos) e agrupar as imagens de seres vivos com o intuito de avaliar como os alunos iriam classificá-las, quais os critérios utilizados e as relações estabelecidas entre as imagens. A atividade foi gravada e cada entrevista individual durou em média de dez a vinte minutos.

Nesta atividade, as imagens foram utilizadas como "estímulos de meios externos" assim como nos estudos desenvolvidos por Vigotski e seus colaboradores sobre o domínio da atenção com crianças em situações artificiais. $O$ intuito do autor era intensificar a atenção imediata para uma atenção mediada em que a criança deveria dominar sua atenção interna apoiando-se nesses estímulos. "Quando a criança passa a dominar sua atenção com base nesses estímulos externos ela passa de um processo mediado externo ao mediado interno" (VYGOTSKY, 1997, p.150-151).

A atenção imediata passa a ser uma atenção mediada em função do desenvolvimento cultural. $\mathrm{O}$ desenvolvimento de qualquer função psíquica superior é um tipo de desenvolvimento cultural e, ao mesmo tempo, social. Vigotski define desenvolvimento cultural, especificamente da atenção, por:

O desenvolvimento cultural de qualquer função, incluída a atenção, consiste em que o ser social no processo de sua vida e atividade elabora uma série de estímulos e signos artificiais. Graças a eles se orienta a conduta social da personalidade; os estímulos e signos formados se convêm no meio fundamental que permite ao indivíduo dominar seus próprios processos de comportamento (VYGOTSKY, 1997, p. 149, tradução nossa).

O uso dos estímulos meios externos para uma atenção mediada foi em função do objetivo da atividade, para permitir que o aluno identificasse os seres vivos, as possíveis semelhanças e diferenças entre eles e relacioná-los a fim de agrupá-los em categorias.

De uma maneira geral, os alunos identificaram entre nove (mínimo) e dezoito (máximo) das vinte e cinco imagens utilizadas conforme o Apêndice F. Das dezenove figuras de seres vivos apresentadas aos alunos, sete delas (algas, árvore, anêmona, bactéria, esponja, 
fungo e musgo) ${ }^{112}$ foram classificadas como seres não vivos. Somente um aluno (A3M12) classificou o ser humano como ser não vivo, mas, no decurso da entrevista, ele percebeu o equívoco e voltou a imagem para o grupo dos seres vivos. Dos seis seres não vivos, somente três (água, sol e Shrek) ${ }^{113}$ foram considerados como seres vivos. Apesar de o personagem Shrek apresentar características antropomórficas, neste estudo ele foi considerado um ser não vivo, por ser um personagem fíctício de um filme de animação com o mesmo título do referido personagem.

Os seres vivos que eles tiveram mais dificuldade em reconhecer foram as algas, o musgo e dois animais invertebrados (anêmona e esponja). Alguns alunos identificaram o lagostim como lagosta e isso foi considerado plausível pelas poucas diferenças visíveis entre as espécies, como o tamanho, o habitat e as pinças, que no último animal são bem maiores. Outros alunos o identificaram como camarão, caranguejo, escorpião e inseto, que se assemelham porque possuem patas articuladas, diferindo-se pelo número de patas para cada uma das espécies citadas. A variação de nomes utilizados pelos alunos na identificação das imagens apresenta-se no Apêndice G, essa variação ocorreu principalmente quando eles não reconheceram as figuras, principalmente as dos seres vivos.

Além disso, outros seres vivos como a perereca, o peixe abissal, a libélula e a jaguatirica foram confundidos com sapo, piranha, mosquito da dengue e onça, respectivamente. Em alguns casos, os alunos identificaram as imagens com nomes típicos da sua região de origem (no caso, o estado do Maranhão) ${ }^{114}$, como por exemplo, ganguji (lesma) e cambito (libélula).

Este fato evidencia a influência do meio social no desenvolvimento do pensamento e da linguagem na criança e, consequentemente, a assimilação de palavras com significados socialmente constituídos. Vigotski (2009) explica como isso ocorre e se configura como um pseudoconceito, uma das formas mais frequentes no pensamento, por complexos, caracterizado pela assimilação dos significados das palavras pelas crianças que são estabelecidos no discurso dos adultos.

Ela já recebe em forma pronta a série de objetos concretos generalizados por aquela palavra. A criança não relaciona espontaneamente uma dada palavra a um determinado grupo concreto e transfere o seu significado de um objeto para outro, ampliando o círculo de objetos abrangidos pelo complexo. Ela

\footnotetext{
112 O número entre parênteses indica o número de vezes que os itens a seguir foramconsiderados seres não vivos: árvore (4), musgo (5), esponja (5), fungo (6), anêmona (5), bactéria (6) e algas (7).

${ }^{113} \mathrm{O}$ número entre parênteses indica o número de vezes que os itens a seguir foram consideradosseres vivos: água (3), sol(3)e Shrek (7).

${ }^{114}$ A entrevistadora não encontrou dados que pudessem corroborar essa variação lexical do estado do Maranhão.
} 
apenas segue o discurso dos adultos, assimilando os significados concretos das palavras já estabelecidos e dados a ela em forma pronta. Em termos mais simples, a criança não cria a sua linguagem mas assimila a linguagem pronta dos adultos que a rodeiam (VIGOTSKI, 2009, p. 196).

Com relação aos critérios utilizados para definir os seres vivos, os alunos utilizaram a alimentação, o crescimento, o movimento (andar, correr, mexer, voar), a respiração e a reprodução. Outros critérios como o fato de serem animais e porque são vivos (têm vida) também foram citados na definição de um ser vivo.

Para classificar os seres vivos, os critérios utilizados pelos alunos foram o movimento (andar, mexer, voar), o habitat (terrestres ou aquáticos) e a semelhança entre os seres vivos selecionados. Quanto ao número de vezes em que o grupo dos seres vivos foi dividido, este variou de um a três, ou seja, todos os alunos conseguiram subdividir o grupo inicial de imagens conforme o quadro 11 a seguir, que apresenta os critérios utilizados nas subdivisões do grupo inicial e os respectivos números das imagens de cada agrupamento elaborado pelo aluno.

Quadro 11. Subdivisão realizada pelos alunos, referente ao grupo inicial de seres vivos

\begin{tabular}{|c|c|c|c|c|c|c|}
\hline Aluno & $1^{\text {a Divisão }}$ & $\begin{array}{l}\text { Imagens } \\
\text { (número)* }^{*}\end{array}$ & $2^{\text {a }}$ divisão & $\begin{array}{l}\text { Imagens } \\
\text { (número) }\end{array}$ & $3^{\text {a divisão }}$ & $\begin{array}{c}\text { Imagens(nú } \\
\text { mero) }\end{array}$ \\
\hline \multirow{3}{*}{ A1F12 } & \multirow[b]{2}{*}{ Animal } & \multirow[b]{2}{*}{$\begin{array}{c}7,8,9,10,12,13 \\
14,23,24\end{array}$} & Aquáticos & 11,23 & & \\
\hline & & & \multirow[b]{2}{*}{ Terrestres } & \multirow{2}{*}{$\begin{array}{c}6,7,8,9 \\
10,12,13 \\
14 \text { e } 24\end{array}$} & $\begin{array}{c}\text { Bichos } \\
\text { venenosos }\end{array}$ & $\begin{array}{c}6,7,10,12 \\
14\end{array}$ \\
\hline & Pessoa & 1,18 & & & $\begin{array}{l}\text { Bichos não } \\
\text { venenosos }\end{array}$ & $8,9,13,24$ \\
\hline \multirow{5}{*}{ A2F11 } & Animais & $\begin{array}{c}7,8,9,10,11,12 \\
13,14,23,24\end{array}$ & África & $8,9,24$ & & \\
\hline & Plantas & $2,3,5,25$ & Mar & 11,23 & & \\
\hline & Mar & $4,6,15,22$ & $\begin{array}{l}\text { Pequenos e } \\
\text { folhas }\end{array}$ & $10,12,14$ & & \\
\hline & Mesmo lugar & 17,20 & \multirow{2}{*}{ Outros } & \multirow{2}{*}{7,13} & & \\
\hline & Ser humano & 1 & & & & \\
\hline \multirow{4}{*}{ A3M12 } & Andam & $\begin{array}{c}6,7,8,9,10,11 \\
12,13,14,15,18 \\
23,24\end{array}$ & Voam & 13,14 & & \\
\hline & \multirow{3}{*}{ Não andam } & \multirow{3}{*}{15} & $\begin{array}{c}\text { Caminham } \\
\text { no mato }\end{array}$ & 8,9 & & \\
\hline & & & Perigosos & $6,7,11$ e 24 & & \\
\hline & & & Nadam & $1,10,12,23$ & & \\
\hline \multirow{2}{*}{ A4M11 } & Terrestres & $\begin{array}{c}6,7,8,9,10,12 \\
24\end{array}$ & & & & \\
\hline & $\begin{array}{l}\text { Voam ou ficam } \\
\text { na água }\end{array}$ & $11,13,14,23$ & & & & \\
\hline \multirow{2}{*}{ A5M10 } & Terrestres & $\begin{array}{c}6,8,9,10,12,13 \\
14,22,24\end{array}$ & Insetos & $\begin{array}{c}6,10,12 \\
14,22\end{array}$ & & \\
\hline & Aquáticos & $1,4,7,11,15,23$ & $\begin{array}{l}\text { Animais do } \\
\text { Zoológico }\end{array}$ & $8,9,13,24$ & & \\
\hline \multirow{6}{*}{ A6F11 } & Árvores & $2,3,5$ & & & & \\
\hline & Peixes & 11,23 & & & & \\
\hline & Mar & $4,15,25$ & & & & \\
\hline & Bactérias & 22 & & & & \\
\hline & Monstro & 18 & & & & \\
\hline & Humanos & 1 & & & & \\
\hline
\end{tabular}




\begin{tabular}{|c|c|c|c|c|c|c|}
\hline & Lugar & 17,20 & & & & \\
\hline & \multirow[t]{2}{*}{ Animal } & \multirow{2}{*}{$\begin{array}{c}6,7,8,9,10,12 \\
13,14,24\end{array}$} & Insetos & $\begin{array}{c}6,7,10,12, \\
14\end{array}$ & & \\
\hline & & & Aracnídeos & 7 & & \\
\hline \multirow{4}{*}{ A7F11 } & Animais e insetos & $\begin{array}{c}6,7,8,9,10,11 \\
12,13,14,23,24\end{array}$ & Aquáticos & 11,23 & & \\
\hline & Bactérias & 22 & \multirow{3}{*}{ Terrestres } & \multirow{3}{*}{$\begin{array}{c}6,7,8,9 \\
10,12,13 \\
14\end{array}$} & Voam & 13,14 \\
\hline & Plantas e árvores & 2,3 & & & Maiores & $8,9,24$ \\
\hline & Ser Humano & 1 & & & Menores & $6,7,10,12$ \\
\hline \multirow{5}{*}{ A8M10 } & $\begin{array}{l}\text { Parecem com } \\
\text { cogumelo }\end{array}$ & $\begin{array}{c}5,8,11,12,13, \\
14,24\end{array}$ & & & & \\
\hline & $\begin{array}{l}\text { Parecem com } \\
\text { árvore }\end{array}$ & $2,3,15$ & & & & \\
\hline & Aquáticos & $1,4,10,23$ & & & & \\
\hline & Nojentos & 6,7 & & & & \\
\hline & $\begin{array}{c}\text { Parecem com } \\
\text { células }\end{array}$ & $9,22,25$ & & & & \\
\hline \multirow{4}{*}{ A9F11 } & Não andam & $11,12,13,14,23$ & & & & \\
\hline & Terrestres & $1,6,7,8,9,24$ & & & & \\
\hline & Aquáticos & $10,11,12,23$ & & & & \\
\hline & Voam & 13,14 & & & & \\
\hline \multirow{3}{*}{ A10F10 } & Não se mexem & $2,3,4,5,25$ & & & & \\
\hline & \multirow[t]{2}{*}{ Mexem } & \multirow{2}{*}{$\begin{array}{c}1,6,7,8,9,10 \\
11,12,13,14,23 \\
24\end{array}$} & Terra & $\begin{array}{c}1,7,8,9 \\
10,12,13 \\
14,24\end{array}$ & Ar livre & $\begin{array}{c}1,7,10,12, \\
13,14\end{array}$ \\
\hline & & & Mar & $6,11,23$ & Zoo (presos) & $8,9,24$ \\
\hline \multirow{6}{*}{ A11F12 } & Ser humano & 1 & & & & \\
\hline & Mamíferos & $8,9,24$ & & & & \\
\hline & Terrestre & 10,12 & & & & \\
\hline & Mar & 11,23 & & & & \\
\hline & Parecidos & 6,7 & & & & \\
\hline & Árvore & 2 & & & & \\
\hline
\end{tabular}

*Legenda do número da imagem: (1) crianças; (2) árvore; (3) musgo; (4) esponja; (5) fungo; (6) lagostim; (7) aranha; (8) girafa; (9) anta; (10) perereca; (11) peixe abissal; (12) lesma; (13) tuiuiú; (14) libélula; (15) anêmona; (16) celular; (17) sol; (18) Shrek; (19) Pedra; (20) água; (21) bola; (22) bactéria; (23) pirarucu; (24) jaguatirica; (25) algas.

Os critérios utilizados no primeiro agrupamento foram o habitat (terrestres ou aquáticos), o movimento (andar e voar) e a semelhança. Um dos alunos (A6F11) agrupou as imagens aproximadamente à classificação taxonômica vigente (bactérias, animais e insetos, árvores e plantas).

Deste primeiro agrupamento, sete alunos realizaram uma subdivisão e os critérios utilizados foram o habitat, o comportamento (perigosos) e as aproximações da taxonomia vigente (insetos e aracnídeos). Por último, somente três alunos chegaram a uma terceira subdivisão e os critérios foram o comportamento (bichos venenosos e não venenosos), o habitat (ar livre e zoológico) e o tamanho (maiores e menores).

Neste momento, o modo de pensamento dos alunos se caracterizou pelo pensamento por complexos com base nas impressões concretas identificadas por eles nas imagens utilizadas como estímulos externos. Vigotski (2009) explica o significado das generalizações nesse modo de pensamento: 
[...] as generalizações criadas por intermédio desse modo de pensamento representam, pela estrutura, complexos de objetos particulares concretos, não unificados à base de vínculos subjetivos que acabaram de surgir e foram estabelecidos nas impressões da criança, mas de vínculos objetivos que efetivamente existem entre tais objetos (VIGOTSKI, 2009, p. 178-179).

As generalizações elaboradas pelos alunos nas subdivisões realizadas com o grupo inicial de seres vivos tiveram como base os vínculos objetivos, que se constituem nas impressões concretas observadas nas imagens de seres vivos e utilizadas nas generalizações para a formação dos grupos e subgrupos resultantes das subdivisões.

Com relação ao ser humano, cinco (A1F12, A2F11, A6F11, A7F11 e A11F12) dos onze alunos, classificaram o ser humano à parte, não sendo considerado como um animal ou um mamífero. O trecho a seguir, do aluno A2F11, exemplifica essa observação:

E: Por que você colocou aqui? (apontando para a figura que representa duas crianças)

A2F11: São humanos?

E: Por que você colocou ele sozinho?

A2F11: Eu achei que os animais, nem as plantas, nem o sol, nem o céu, nem os mares combinavam com esse, aí eu botei ele só.

E: Então você acha que o ser humano não é um animal?

A2F11: Não.

E: Por quê?

A2F11: Porque eles é diferente. Dos animais, mais diferentes deles!

Em outro trecho, o aluno A6F11utiliza a expressão "não se deram bem" para justificar a colocação à parte da imagem dos seres humanos:

E: Qual é o grupo?

A6F11: Dos humanos.

E: Dos humanos.

A6F11: Esse é o grupo dos animais.

E: Por que os humanos ficam separados?

A6F11: Porque eu achei que eles não se deram bem nem com os animais, nem com os insetos, nem com os peixes, nem com as paisagens...

E: Por que você acha que ele não é um animal?

A6F11: Porque ele é uma pessoa.

E: Ele não é animal então, o ser humano não é animal. O que é animal para você?

A6F11: É os que comem, se reproduz... Comem, se reproduzem, constroem seu próprio habitat, caça...

E: Nós não fazemos isso?

A6F11: E é predador.

E: Nós não fazemos isso? Nós não comemos, não...?

A6F11: Comemos, mas a gente não é um predador.

E: Todos esses que você colocou aqui são predadores?

A6F11: Sim.

E: Sim? O que é predador?

A6F11: Predador é que você come outro animal. 
O trecho acima apresenta uma noção de ser humano que não é considerado como um animal (A2F11) e nem como predador (A6F11). Para esse aluno, o termo predador está restrito aos animais que se encontram no último nível da cadeia alimentar, principalmente os mamíferos de grande porte como o leão, a onça e o tigre. No caso do ser humano, este termo abrange o sentido de destruição do meio ambiente em função de ações antrópicas.

Para Pinto-Coelho (2000, p. 43), a predação é definida como o "ato de um animal consumir o outro para dele alimentar-se. Esse ato envolve, na maioria dos casos, a morte da presa". O autor apresenta cinco tipos de predação: carnívoros de primeira ordem (consumidores de herbívoros); predadores de carnívoros; herbívoros (consumidores de plantas inteiras ou parte delas); insetos parasitoides (as larvas que se alimentam do hospedeiro) e canibais (consumidores de indivíduos da própria espécie). Com base nesse conceito de predação, o homem também pode ser considerado como predador porque consome outros animais para alimentar-se, sejam eles produzidos em granjas, como os frangos, ou obtidos no ambiente natural, como os peixes.

\section{(b.3.2) Relações ecológicas}

O tempo de execução da atividade anterior foi insuficiente para desenvolver o tema sobre a interdependência entre os seres vivos e não vivos, assim como estabelecer as relações ecológicas por causa da diversidade de seres vivos e habitats que suscitaram dúvidas pelos alunos. A partir desse fato, considerou-se pertinente elaborar esta atividade para que os alunos percebessem essas relações e a interdependência entre os seres (vivos e não vivos), constituindo-se um dos atributos do conceito ecossistema. Esta atividade foi subdividida em duas etapas: o jogo da teia alimentar e a elaboração de uma cadeia alimentar.

\section{O jogo da teia alimentar}

Antes de iniciar a atividade, a entrevistadora questionou os alunos com a seguinte pergunta: Quem é ser vivo aqui? Para possibilitar a retomada dos conceitos de ser vivo e não vivo e as suas respectivas características. Os alunos responderam positivamente a questão, com exceção de um aluno que, em tom de brincadeira, deitou-se e fingiu-se de morto. A segunda questão foi: Por que nós somos seres vivos? Os alunos justificaram com as características relacionadas ao movimento (porque se mexem, andam) e à vida (considerando aqueles seres que possuem intestino e coração). 
A entrevistadora retomou a discussão questionando quais seriam então as outras características dos seres vivos. A respiração, a alimentação, a reprodução, a forma e tamanho definidos foram algumas das características explicitadas para os alunos.

Quanto aos seres não vivos, questionou-se por que eles são seres não vivos. As respostas foram antagônicas às características elencadas para os seres vivos: não respiram, não se reproduzem, não têm coração e não têm vida. Os exemplos listados pelos alunos referem-se a objetos construídos pelo homem, como, por exemplo, quadro, mesa, papel, cadeira, porta, sandália, e que, no caso, faziam parte do seu ambiente (sala de aula).

Quando a entrevistadora perguntou quais seriam os seres não vivos no nosso ambiente natural, os alunos responderam pedra, rio, água, vento, frio, neve, sol e terra. Além desses, a árvore e o mato também foram citados como seres não vivos e a entrevistadora retomou as características destes primeiros justificando a sua classificação como seres vivos.

A entrevistadora iniciou o jogo ${ }^{115}$ sendo a cenoura e, à medida que os alunos respondiam com a escolha de um ser vivo que se alimentava de outro, as discussões eram mediadas. As cadeias eram finalizadas quando atingiam o último nível trófico ${ }^{116}$ ou quando os alunos citavam um predador. A formação de várias cadeias teve o intuito de possibilitar, no decurso da atividade, a representação de uma teia alimentar formada pelo entrelaçamento dos fios de barbante segurados pelos alunos e de eles perceberem a interdependência entre os seres vivos. E ainda contemplar todos os participantes, apesar de alguns alunos terem representado mais de um ser vivo. A seguir, as cinco cadeias que foram elaboradas, iniciadas por um produtor (seres autótrofos) e finalizadas por agentes decompositores ou predadores:

Cadeia 1: cenoura (E); coelho (A11F12), águia (A8M10), urubu (A7F11). Nesse caso, a entrevistadora explicou que o urubu só poderia comer a águia se ela estivesse morta.

Cadeia 2: manga (A3M12), ser humano (A5M10), inseto (A6F11), agentes decompositores (E);

Cadeia 3: insetos (A6F11), sapo (A10F10), cobra (A1F12) e onça (A7F11).

\footnotetext{
${ }^{115}$ Os alunos foram convidados a sentarem em círculo para iniciar a atividade em que o aluno escolhia um ser vivo e amarrava o fio do novelo do barbante e jogava para outro aluno, perguntando qual ser vivo poderia comer aquele que o primeiro aluno havia escolhido. $\mathrm{O}$ aluno que respondia a pergunta pegava novamente o barbante e $\mathrm{o}$ enrolava no dedo, repetindo a pergunta e dando continuidade à atividade.

${ }^{116} \mathrm{O}$ último nível trófico é ocupado pelos organismos decompositores, que se alimentam dos organismos dos níveis subjacentes.
} 
Quando se perguntou aos alunos quem comeria a onça, dois deles responderam o leão. Nesse momento, a entrevistadora questionou onde existiam leões aqui no Brasil e esclareceu sobre o continente de origem (habitat natural) desse animal, conforme o trecho, a seguir.

E: Nós temos leões aqui no Brasil?

Alunos: Têm.

E: Aonde?

Alunos: Na floresta! No zoológico! Na África!

E: Da África, exatamente. Não existe aqui no nosso ambiente natural o leão. Quais os outros animais da África que nós temos somente no Zoo?

Alunos: Girafa, elefante, cobra, macaco, onça.

E: A onça pintada é daqui do?

Alunos: do Brasil!

A8M10: E o guepardo?

E: De onde é o guepardo? Da África também. A gente chama esses animais de animais exóticos.

Cadeia 4: morango (A9F11), pássaro (A6F11), gavião (A2F11), caçador (A0M11 $\left.{ }^{117}\right)$, jacaré (A5M10).

Assim como em trechos citados anteriormente, o aluno não considera o ser humano como um predador, mesmo o reconhecendo como um caçador, ou seja, o conceito de predador fica restrito aos animais e o homem não é incluso como tal.

Em outro momento, a discussão entre os alunos foi sobre quem poderia comer o jacaré, um aluno respondeu o hipopótamo e outro, o tubarão. O trecho, a seguir, apresenta a discussão sobre esse fato:

E: O hipopótamo come o jacaré?

Alunos: Simmm!

E: O hipopótamo não come o jacaré porque ele é um animal herbívoro. Vocês sabem o que é um animal herbívoro?

A7F11: Que come vegetal?

E: Isso! Que come vegetais, que come plantas. Vamos pensar em outros?

A8M10: Tubarão!

E: Vocês falaram tubarão! Tubarão come o jacaré? Vamos pensar? Se não vocês não vão entender. Por que o tubarão não come o jacaré?

Gabriel: Porque o tubarão é de água de sal (mar) e o jacaré de rio.

\footnotetext{
${ }^{117}$ Para a identificação dos alunos que não participaram de todas as atividades individuais, optou-se por estabelecer um código alfanumérico composto pela letra $\mathrm{A}$ (aluno) e o número 0 , a letra inicial $\mathrm{F}$ ou $\mathrm{M}$ referente ao sexo da criança (F para feminino e M para masculino), e, por último, a idade. Então, por exemplo, o código A0M11 significa que é um aluno não participante dos dados gerados na análise individual, do sexo masculino, deonze anos.
} 
Cadeia 5: abacate (A0M13), porco (A2) e serpente (A4).

Após a elaboração da cadeia 5, a entrevistadora questionou os alunos sobre o que havíamos realizado na atividade, eles responderam que era uma cadeia alimentar e perceberam que cada ser vivo se alimenta de outro para sobreviver.

A entrevistadora continuou com os questionamentos, como a dependência de seres vivos e não vivos, e o que ocorre se não houver um desses seres no ambiente, se existe um ambiente totalmente desequilibrado e, ainda, se as cidades são um ambiente natural ou artificial. Ao final das discussões, ressaltou-se a importância da interdependência entre os seres vivos e os seres não vivos e retomaram-se os conceitos de carnívoros, herbívoros e onívoros para explicar a atividade seguinte sobre a montagem de uma cadeia alimentar. $\mathrm{O}$ jogo da teia alimentar teve duração de cinquenta minutos.

\section{Elaboração de uma cadeia alimentar}

Esta atividade individual teve como objetivo reforçar os conceitos discutidos no jogo da teia alimentar, como carnívoros, decompositores, herbívoros, produtores e onívoros, que são importantes para a apreensão de um dos atributos do conceito de ecossistema: a interdependência entre os seres vivos e não vivos.

Para a etapa de ensino e o ano em que foi desenvolvido o estudo, o tema ecossistema contempla os conteúdos referentes aos seres vivos, aos seres não vivos e à relação entre os seres vivos quanto ao nível de cadeia alimentar, conforme o Currículo em Movimento da SEE-DF (DISTRITO FEDERAL, 2014b, p. 126-127).

A partir dos anos subsequentes, o nível de formulação ${ }^{118}$ do conceito de ecossistema integra outros atributos, como a transferência de matéria e o fluxo de energia.

Os alunos foram solicitados a elaborar uma cadeia alimentar com a utilização de imagens ${ }^{119}$ fixas de seres vivos. Além disso, eles foram orientados a desenhar, quando necessário, o ser vivo imaginado, caso este não constasse nas imagens disponíveis para completar a sua cadeia alimentar. Dos onze alunos, seis desenharam e um escreveu o nome do ser vivo para completar a sua cadeia, os quatro restantes utilizaram somente as imagens disponibilizadas para a realização da atividade. O aluno A5M10 montou mais de uma cadeia.

\footnotetext{
118 Giordan e De Vecchi (1996, p. 189) consideram que um nível de formulação "é determinado por uma soma de conhecimentos necessários para construir um enunciado, um estágio de evolução no desenvolvimento psicogenético e uma prática social (vivência constituindo o suporte para a formulação do conceito)."

${ }^{119}$ As imagens fixas utilizadas na atividade 3.1 também foram disponibilizadas para a montagem da cadeia.
} 
Ao total, obtivemos sete cadeias alimentares de ambientes terrestres (representados pelas folhas brancas) e quatro de ambientes aquáticos (representados pelas folhas verdes). A principal dúvida dos alunos gerada nesta atividade refere-se ao fato de quem se alimentava de quem, ou seja, de quais seres vivos. Somente um aluno (A6F11) não incluiu um ser vivo produtor (autótrofo) na sua cadeia alimentar. E dois alunos, A7F11 e A10F10, indicaram que as plantas se "alimentam" do sol.

Os alunos fizeram o uso de setas para indicar quem se alimenta de quem sem que fossem orientados para tal. A maioria de os alunos indicou corretamente o sentido da seta (da esquerda para a direita) de quem se alimenta de quem. Outros alunos, como o A5M10 e o A9F11, utilizaram algumas setas invertidas e outras corretas. O aluno A2F11 utilizou a seta em ambos os sentidos o que indica que o ser vivo tanto come como pode ser comido. A seguir, o quadro 12 apresenta as cadeias alimentares elaboradas pelos alunos.

Giordan e De Vecchi (1996) destacam que a cadeia alimentar é representada de diversas maneiras, mas que podem trazer algumas concepções ${ }^{120}$ induzidas por tais modelos. Entre as citadas pelos autores, destacam-se:

Um animal só se alimenta com uma única espécie de presa. É sempre a maior que come o menor, e o animal colocado no fim da cadeia é o mais forte, o mais poderoso. Um ser vivo é comido em sua totalidade. [...] A transferência de matéria (ou energia) só pode ser linear. Um animal não pode ser ao mesmo tempo, consumidor de primeira e segunda ordem, ele é 'catalogado'. A nutrição concerne a um indivíduo e não é abordada no nível da espécie (o que torna mais delicadas as abordagens ecológicas) (GIORDAN; DE VECCHI, 1996, p. 205).

Os resultados gerados corroboram os estudos de Giordan e De Vecchi (1996), pois se observa que a primeira concepção envolve um aspecto cultural em que, por exemplo, o macaco só se alimenta de banana (neste caso, a presa é substituída pelo primeiro nível de consumo), mas que também pode se alimentar de outras frutas ou sementes disponíveis em seu ambiente natural.

A segunda concepção de que "é sempre a maior que come a menor e o animal colocado no fim da cadeia é o mais forte, o mais poderoso" pode ser observada nas cadeias elaboradas pelos alunos A3M12, A5M10, A7F11 e A11F12, nas quais a onça foi o predador mais utilizado no último nível alimentar, seguida da cobra e do tubarão, respectivamente.

${ }^{120} \mathrm{O}$ termo concepção utilizado por estes autores "ressalta a ideia, [...] de elemento motor que entra na construção de um saber e até permite as transformações necessárias” (GIORDAN; DE VECCHI, 1996, p. 89). 
Além disso, Giordan e De Vecchi (1996) consideram que o uso de setas que indicam "ser comido por" pode criar um obstáculo quando for necessário o aluno utilizar um modelo na direção oposta para entender a transferência de matéria ou energia.

Quadro 12. Cadeia alimentar elaborada pelos alunos na Atividade 3.2.

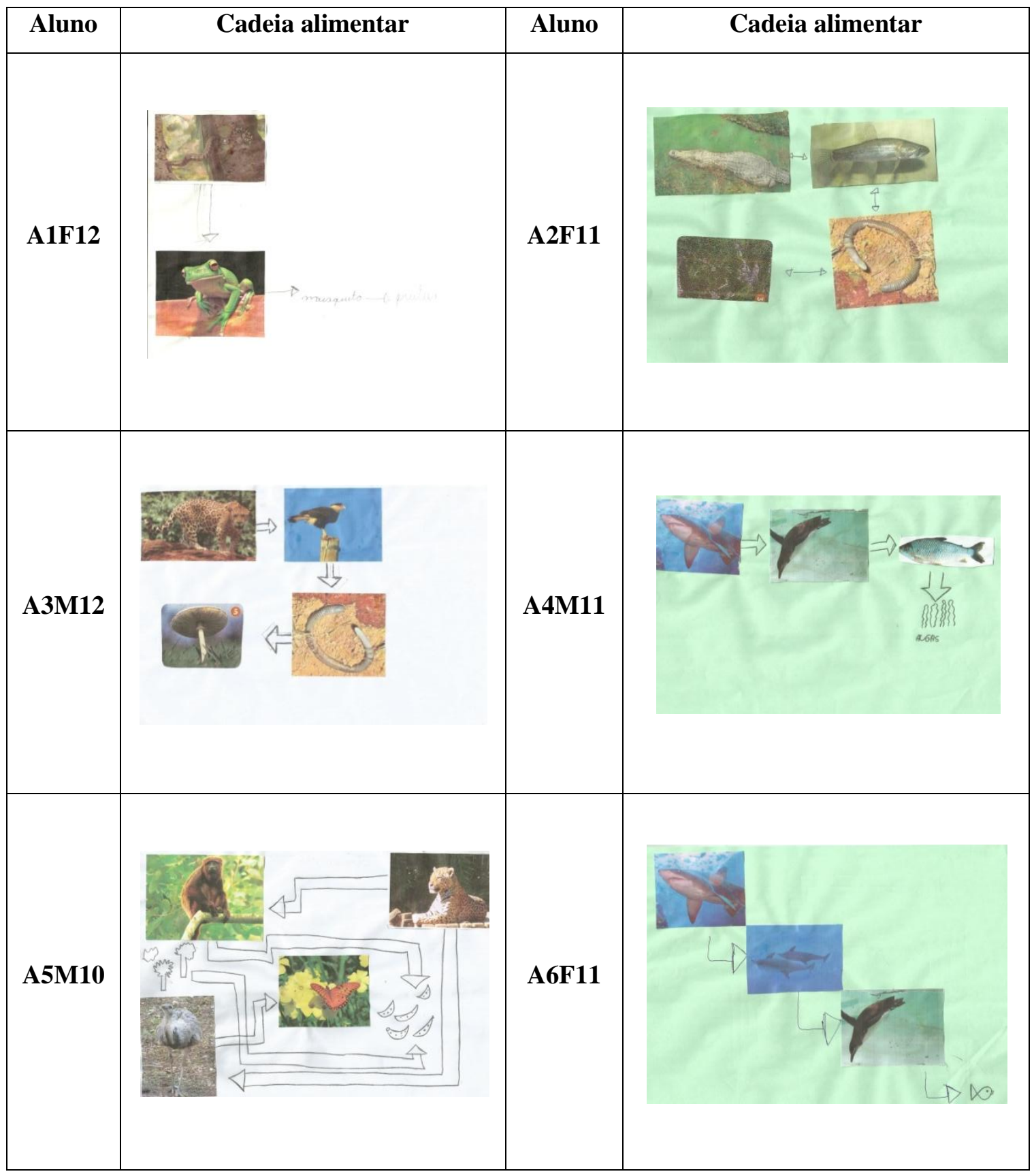




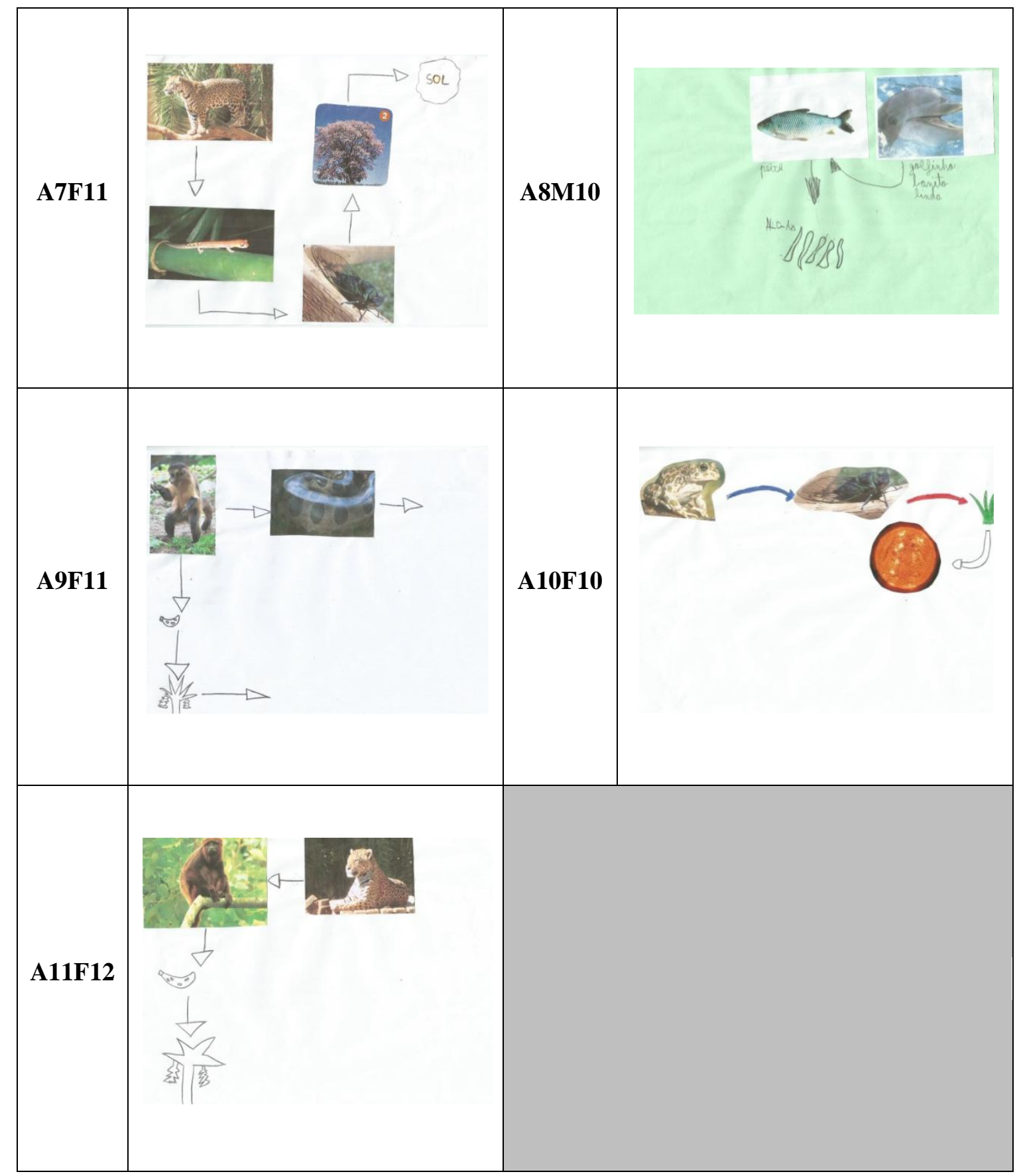

\section{(c) Sessão de desenho animado}

\section{(c.1) Sessão 1}

Antes de iniciar a primeira sessão, retomou-se a aula com questionamentos sobre as preferências dos alunos em relação aos desenhos animados e quais tinham sido utilizados em sala de aula pela professora. As respostas expressadas quanto à preferência foram bastante diversas. A princípio, os alunos disseram que não gostavam, em contrapartida, outros 
informaram que gostavam e alguns, que gostavam mais ou menos. O aluno A7F1 retrucoucom a pergunta "Quem não gosta?". A princípio, os alunos não se lembraram de quais desenhos animados eles haviam assistido em sala. Logo depois, eles começaram a listar, por exemplo, Frozen, uma aventura congelante (EUA, 2013), Madagascar (EUA, 2005), Perdido pra cachorro (EUA, 2008) e Tá chovendo hambúrguer 2 (EUA, 2013). Ao final da conversa, alguns alunos também citaram os seus desenhos preferidos.

Além disso, durante esta conversa retomaram-se os conceitos de ser vivo, de ser não vivo, de cadeia alimentar e de ecossistema. Os seres vivos foram definidos pelos alunos como sendo aqueles que se reproduzem, se alimentam, respiram, nascem, vivem e morrem. Os seres não vivos foram definidos como aqueles que não se mexem, "não têm vida" (A11F12), não têm coração, "não respiram" (A9F11).

A cadeia alimentar foi definida como os animais que se alimentam de outros animais. A última pergunta foi acerca da palavra ecossistema e os alunos responderam em consonância com as definiçõos propostas anteriormente no texto sobre o desenho e nas entrevistas individuais, como ecologia, natureza, reciclagem e sistema ecológico.

Após a conversa, o desenho animado Meu corpo, meu mundo foi projetado no quadro branco na sala de aula do $5^{\circ}$ ano $\mathrm{B}$, utilizando o computador interativo. A exibição completa do desenho durou dezesseis minutos conforme previsto na sinopse da ficha técnica. Os alunos demonstraram interesse durante a exibição e reagiram positivamente diante das cenas com gestos e breves comentários sobre as situações apresentadas pelo Professor Lecré.

\section{Atividade 4: Contação de história}

Após a exibição completa do desenho animado, os alunos foram solicitados a elaborar um texto contando a história. Essa atividade tinha como objetivo verificar se os alunos compreenderam a narrativa do desenho. Ao final do texto, eles poderiam emitir a sua opinião, somente o aluno A8M10 não emitiu a sua opinião sobre o desenho animado.

No Apêndice $\mathrm{H}$, encontram-se os textos transliterados na íntegra, o número entre parênteses refere-se à contagem de palavras de cada um deles para comparação posterior com a atividade 7 , recontar a história.

Quanto à compreensão da narrativa, os alunos identificaram as personagens apresentadas no desenho e abordaram os temas que estavam relacionados ao ecossistema, como o consumo e o gasto de energia, a poluição (do ar, da água e do solo) e a mudança de atitude da família Tal, que poderia contribuir para a preservação do meio ambiente. Os alunos 
A1F12 e A4M11 colocaram-se como se fossem o Prof. Lecré para narrar a história do desenho animado.

Para Vigotski (2009, p. 312), a linguagem escrita não é uma simples tradução da linguagem falada para signos escritos, no caso, as palavras como meio de expressão da história narrada no desenho animado. $\mathrm{O}$ autor considera a escrita como uma função específica de linguagem "que [se] difere da fala não menos como a linguagem interior difere da linguagem exterior pela estrutura e pelo modo de funcionamento".

O desenvolvimento da linguagem escrita demanda um alto grau de abstração porque se constitui em uma linguagem de pensamento que se difere substancialmente da linguagem falada e requer do aluno uma dupla abstração, tanto do aspecto sonoro da linguagem quanto de um interlocutor. Este lado abstrato da escrita constitui-se em uma das dificuldades que o aluno escolar tem diante de si e a outra, a ausência de um interlocutor, como explica o autor:

É natural que a linguagem sem um som real, que é apenas concebível, que requer uma simbolização dos símbolos sonoros, ou melhor, uma simbolização de segunda ordem, deve ser igualmente mais difícil que a linguagem falada (VIGOTSKI, 2009, p.314).

Apesar das investigações de Vigotski se referirem aos alunos no início da aprendizagem escolar sobre esse aspecto teórico, os resultados gerados permitem indicar que a dificuldade da transferência da linguagem falada para a escrita pode ocorrer nos anos subsequentes, especificamente neste estudo, o $5^{\circ}$ ano do Ensino Fundamental.

\section{Atividade 4.1: Descrição das cenas da narrativa do desenho animado}

Em um segundo momento, após a elaboração do texto da contação de história, os alunos foram convidados a escolher uma cena decupada (recortes por minuto do desenho animado) para explicitar o que havia ocorrido nela e, assim, possibilitar verificar a compreensão dos fatos que se sucederam na narrativa do desenho animado. A seguir, o quadro 13 apresenta a cena, a descrição e a sequência enumerada pelos alunos. 
Quadro 13. Compilação dos dados gerados da Atividade 4.1.

\begin{tabular}{|c|c|c|c|}
\hline $\begin{array}{l}\text { Decupagem } \\
\text { por minuto }\end{array}$ & Imagem da Cena & $\begin{array}{l}\text { Descrição elaborada } \\
\text { pelos alunos }\end{array}$ & $\begin{array}{c}\text { Número da sequência } \\
\text { enumerada pelos } \\
\text { alunos }\end{array}$ \\
\hline $1 ’ 00$ & & $\begin{array}{l}\text { "Na hora que o globo caiu } \\
\text { e ele foi buscar" (A2F11) }\end{array}$ & 2 \\
\hline $2^{\prime} 00$ & & $\begin{array}{l}\text { "Ele ta mostrando aqui que } \\
\text { o...esqueci aquela parte } \\
\text { do...do sistema ecológico } \\
\text { que é usado para fazer o } \\
\text { plástico." (A1F12) }\end{array}$ & 3 \\
\hline 3’00 & & $\begin{array}{l}\text { "Na hora que ele tava } \\
\text { barbeando a barba dele, } \\
\text { olhando para o espelho e } \\
\text { deixando o chuveiro } \\
\text { ligado." (A4M11) }\end{array}$ & 5 \\
\hline 4’00 & & $\begin{array}{l}\text { "A parte que ele falou que } \\
\text { quando tudo fica ligado } \\
\text { gasta mais energia." } \\
\text { (A9F11) }\end{array}$ & 7 \\
\hline $5^{\prime} 00$ & & $\begin{array}{l}\text { "No começo quando ele } \\
\text { tava falando aí depois } \\
\text { pun...porque antes do } \\
\text { globo cair, ele estava } \\
\text { falando aí o globo caiu e } \\
\text { ele foi buscar." (A8M10) }\end{array}$ & 1 \\
\hline
\end{tabular}




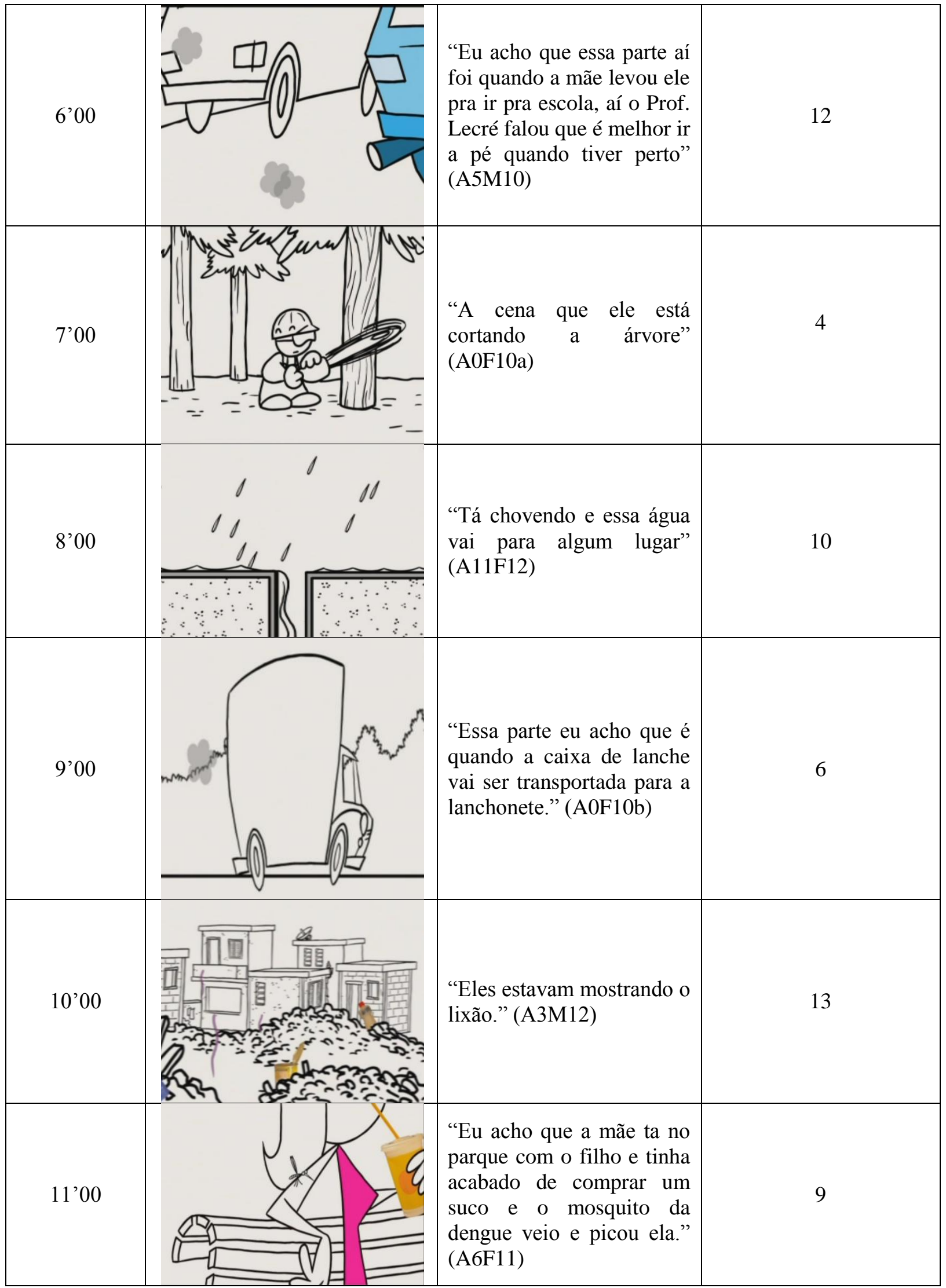




"É quando eles chegam do
trabalho $\mathrm{e}$ o filho dele
tem...bronquite...Aí eles
icaram doentes por causa
da fumaça, do mosquito."
A7F11)

De uma forma geral, pode-se dizer que os alunos compreenderam a proposta e tiveram sucesso na identificação da progressão das cenas do desenho, ainda que tenham ocorrido desvios na ordem criada por eles em relação à original.

Em seguida, os alunos foram convidados a relembrar a história e, juntamente à entrevistadora, as cenas foram renumeradas na sequência em que ocorreram os fatos, corrigindo os desvios anteriormente citados. Neste momento, levantaram-se alguns questionamentos sobre a narrativa para promover as interações dialógicas, realizar as discussões pertinentes nas cenas e relacioná-las umas com as outras e com o que os alunos haviam relatado durante a atividade. O quadro 14 apresenta a disposição das cenas afixadas na lousa branca e o seu respectivo número, antes e depois da mediação da entrevistadora. 
Quadro 14. Sequência da narrativa remontada pelos alunos na lousa branca, referente à Atividade 4 .

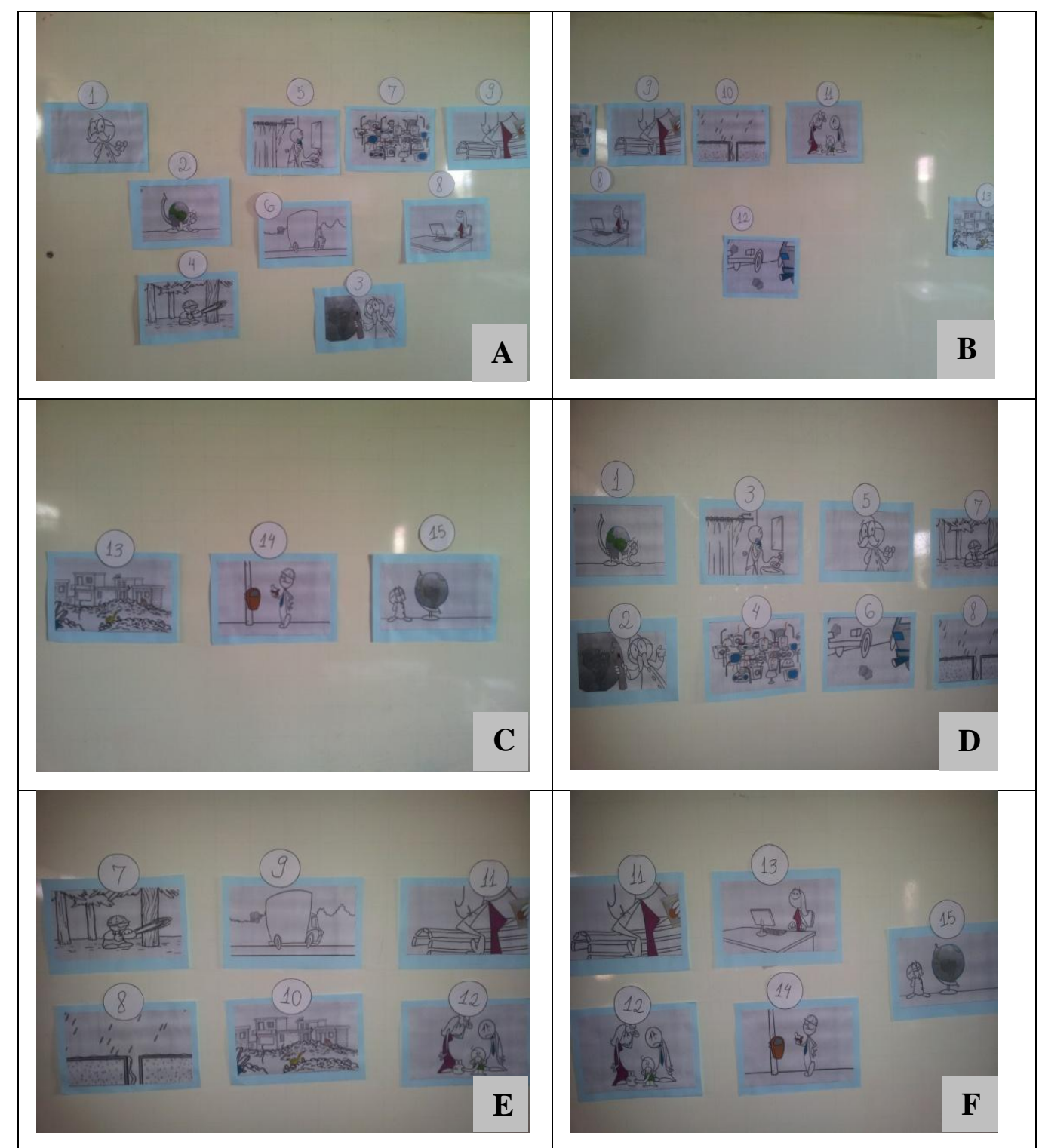

Legenda: Sequência montada pelos alunos (A-C) e sequência reelaborada com a mediação da entrevistadora (DF).

\section{(c.2) Sessão 2}

\section{Atividade 5: Debate 1}

Na sessão 2, o desenho animado foi reexibido com momentos de pausa previamente definidos para a promoção do primeiro debate. Esta atividade teve como objetivo desenvolver o conceito de ecossistema. A turma foi dividida em dois grupos (Grupo A e Grupo B), um dos alunos de cada grupo era escolhido para responder os questionamentos levantados pelo Prof. Lecré, contidos na narrativa do desenho, e aqueles elaborados como complementares. Os 
integrantes de cada grupo foram instruídos a colaborar na resposta do aluno convocado quando julgassem necessário.

Durante a mediação, outros conceitos foram novamente retomados, como carnívoros, herbívoros e onívoros. Depois da resposta do aluno convocado, a entrevistadora dirigia-se para o outro grupo, questionando se ele queria complementar a resposta para realizar a mediação entre os grupos. A entrevistadora complementava as ideias expostas pelos grupos para esclarecer as informações ou os conceitos envolvidos. A seguir, o quadro 15 apresenta os momentos de pausa, os questionamentos, as respostas dos alunos e os complementos dos grupos. Vale observar que as respostas dos alunos se referem às informações transmitidas na narrativa do desenho animado.

De uma maneira geral, tanto as respostas dos alunos quanto os complementos elaborados pelos grupos foram pertinentes às informações apresentadas na narrativa do desenho animado. Na segunda pausa, quando se questionou o que era ecossistema para o Prof. Lecré, o aluno A9F11 respondeu "que se um falhar os outros não conseguem sobreviver, precisa de todo mundo para poder sobreviver" e o aluno A10F10 respondeu como complemento referindo-se à atividade do jogo da teia alimentar, realizada anteriormente, demonstrando a interdependência entre os seres "aquela brincadeira aquela vez tipo a cadeia alimentar, se um não existir, nenhum existe”.

O Cerrado, a Caatinga e a Floresta Amazônica foram os exemplos de ecossistema apresentados pelos Grupos A e B. A partir dessas respostas, pode-se inferir que os argumentos elaborados pelos alunos estejam relacionados a experiências anteriores deles após o contato com o termo na primeira atividade, tendo em vista que não utilizaram esses exemplos na concepção inicial e a narrativa do desenho não cita exemplos de ecossistema.

$\mathrm{Na}$ terceira pausa, percebe-se nas respostas dos alunos que eles identificam as ações humanas que são prejudiciais ao meio ambiente e demonstram saber o que é necessário ser realizado para conservá-lo.

$\mathrm{Na}$ quarta pausa, a fala do alunoA0F10b destaca-se pela quantidade de informações referentes à sua explicação sobre o equilíbrio do ecossistema. A sua concepção inicial é: "Meu ecossistema ele funciona faciumente. O nome é sistema ecológico, ou seja, ele separa o lixo em cinco partes: papel, plástico, metal, vidro e organico. Ele ajuda a natureza e ajuda a reciclar coisas que jogamos fora". 
Quadro 15. Compilação dos dados gerados a partir das manifestações dos Grupos A e B na Atividade 5.

\begin{tabular}{|c|c|c|c|}
\hline Momento de pausa & Questionamentos & "Resposta "do aluno & Complemento do (s) grupo (s) \\
\hline \multirow[t]{2}{*}{$\begin{array}{l}\text { 1' Pausa } \\
(1 \text { '07”) }\end{array}$} & $\begin{array}{l}\text { Pergunta 1: "Uma gota de vida } \\
\text { boiando no universo em perfeita } \\
\text { harmonia. Mas será que é tão } \\
\text { simples assim? Pois é, o planeta } \\
\text { precisa de cuidados! Você já } \\
\text { pensou que tudo que precisa para } \\
\text { viver vem do planeta?" } \\
\text { (transcrição da fala do Prof. } \\
\text { Lecré) }\end{array}$ & $\begin{array}{l}\text { "Não estragar comida...não ficar } \\
\text { matando animais...não ficar } \\
\text { tocando fogo nas coisas" } \\
\text { (A4M11/GA) }\end{array}$ & $\begin{array}{l}\text { "Que a gente tem que poluir menos, usar menos eletricidade } \\
\text { porque senão o ecossistema, é..." (A7F11/GB) }\end{array}$ \\
\hline & $\begin{array}{l}\text { Pergunta 2: Você já pensou que } \\
\text { tudo que precisa para viver vem } \\
\text { do planeta? Dê exemplos. }\end{array}$ & $\begin{array}{l}\text { "Humrum (sinaliza positivamente } \\
\text { com a cabeça) Tipo o pão que } \\
\text { vem do trigo e também o } \\
\text { chocolate que é do cacau...e } \\
\text { jabuticaba...porque tem no pé" } \\
\text { (A8M10/GB) }\end{array}$ & $\begin{array}{l}\text { "O ar" (A6F11/GB) } \\
\text { "A laranja" (A11F12/GB) } \\
\text { "O tomate que a vaca come para dar leite para fazer essas } \\
\text { coisas" (A7F11/GB) }\end{array}$ \\
\hline \multirow[t]{2}{*}{$\begin{array}{l}\text { 2 }^{\text {a }} \text { Pausa } \\
\text { (2'07') }\end{array}$} & $\begin{array}{l}\text { Pergunta 3: O que é ecossistema } \\
\text { para o Prof. Lecré? }\end{array}$ & $\begin{array}{l}\text { "Que se um falhar os outros não } \\
\text { conseguem sobreviver, precisa de } \\
\text { todo mundo para poder } \\
\text { sobreviver" (A9F11/GA) }\end{array}$ & $\begin{array}{l}\text { "é que como a gente tinha fazido aquela brincadeira aquela } \\
\text { vez tipo a cadeia alimentar, se um não existir nenhum existe" } \\
\text { (A10F10/GA) } \\
\text { "Porque se não existisse...tipo, o sol, como ia crescer a } \\
\text { planta, o outro animal ia alimentar da planta" (A7F11/GB) }\end{array}$ \\
\hline & $\begin{array}{l}\text { Pergunta 4: Vocês poderiam me } \\
\text { apresentar } \quad \text { exemplos de } \\
\text { ecossistema? }\end{array}$ & $\begin{array}{l}\text { A aluna A6F11 (GB) não } \\
\text { respondeu }\end{array}$ & $\begin{array}{l}\text { "Cerrado" }(\mathbf{A 1 1 F 1 2 / G B}) \\
\text { "Caatinga" }(\mathbf{A 3 M 1 2 / G A}) \\
\text { "Floresta Amazônica" }(\mathbf{A 2 F 1 2 / G B})\end{array}$ \\
\hline $\begin{array}{l}3^{a} \text { pausa } \\
\left(22^{\prime} \text { ') }\right.\end{array}$ & $\begin{array}{l}\text { Pergunta 5: Como é que nós, } \\
\text { seres humanos, temos colaborado } \\
\text { com os ecossistemas do nosso } \\
\text { planeta? (transcrição da fala do } \\
\text { Prof. Lecré) }\end{array}$ & "Deixando limpo" (A0M13/GA) & $\begin{array}{l}\text { "Reciclando o lixo, não desmatando o meio ambiente e não } \\
\text { jogar o lixo no chão" (A3M12/GA) } \\
\text { "Andando mais de ônibus, se não der andar a pé, andar de } \\
\text { bicicleta, se não der andar de ônibus" (A10F10/GA) }\end{array}$ \\
\hline
\end{tabular}




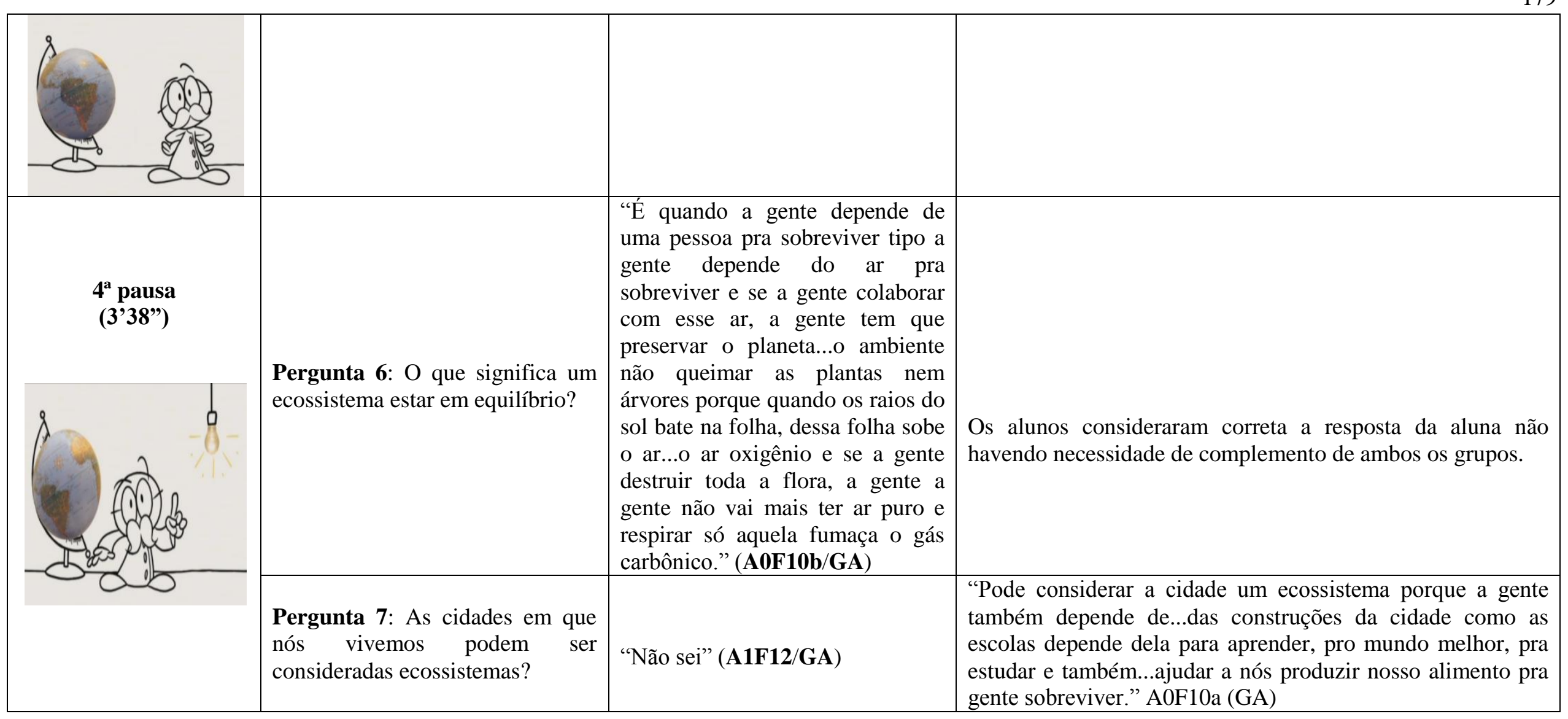


Neste caso, acredita-se que o aluno integrou novos conhecimentos, além daqueles apresentados na narrativa do desenho identificados na resposta do aluno como "quando os raios do sol bate na folha, dessa folha sobe o ar...o ar oxigênio" e "não vai mais ter ar puro e respirar só aquela fumaça o gás carbônico", respectivamente.

\section{(c.3) Sessão 3}

\section{Atividade 6: Debate 2}

Na sessão 3, o desenho foi reexibido desde o começo até a primeira pausa estipulada (2'35").A atividade 6 teve o intuito de dar continuidade às discussões iniciadas na atividade 5, com o enfoque sobre as ações antrópicas provocadas no ecossistema e abordadas na narrativa do desenho animado.

Após a primeira pausa, a formação inicial dos grupos A e B foi mantida e solicitou-se aos alunos que discutissem as causas e as consequências das ações antrópicas no ecossistema. As cinco causas e consequências de cada grupo foram redigidas pelos alunos, sendo as primeiras representadas por folhas azuis e as segundas, por folhas amarelas. As folhas foram compiladas e afixadas na lousa branca por um representante do grupo. Depois, por decisão dos grupos e caso houvesse necessidade, cada um poderia escolher outro representante para explicar para a turma o que havia sido registrado nas folhas.

Posteriormente à segunda pausa (12'00”), os grupos foram solicitados novamente a discutirem as soluções, sendo estas registradas em folhas brancas. A seguir, o quadro 16 apresenta a transliteração e a compilação dos dados gerados pelos Grupos A e B na atividade 6.

Quadro 16. Compilação dos dados gerados pelos grupos A e B na Atividade 6.

\begin{tabular}{|c|c|c|c|c|c|}
\hline \multicolumn{1}{|c|}{ GRUPO A } & \multicolumn{3}{c|}{ GRUPO B } \\
\hline $\begin{array}{c}\text { Poluição na } \\
\text { água }\end{array}$ & Consequência & Solução & Causa & Consequência & Solução \\
\hline Poluição no ar & $\begin{array}{c}\text { Não jogar } \\
\text { lixo na água }\end{array}$ & $\begin{array}{c}\text { Gasto de } \\
\text { energia }\end{array}$ & $\begin{array}{c}\text { Falta de luz e } \\
\text { contas de luz } \\
\text { altas }\end{array}$ & $\begin{array}{c}\text { Economizar } \\
\text { energia e } \\
\text { usar menos } \\
\text { aparelhos } \\
\text { elétricos }\end{array}$ \\
$\begin{array}{c}\text { respiratórias } \\
\text { Não jogar } \\
\text { lixo nas ruas }\end{array}$ & $\begin{array}{c}\text { Queimar } \\
\text { florestas }\end{array}$ & $\begin{array}{c}\text { Não gastar } \\
\text { energia } \\
\text { porque } \\
\text { respiratórias } \\
\text { acontece o } \\
\text { aquecimento } \\
\text { global e }\end{array}$ \\
\hline
\end{tabular}




\begin{tabular}{|c|c|c|c|c|c|}
\hline & & & & $\begin{array}{c}\text { acontece } \\
\text { queimada } \\
\text { por causa do } \\
\text { sol }\end{array}$ \\
\hline $\begin{array}{c}\text { Gasto de } \\
\text { energia }\end{array}$ & $\begin{array}{c}\text { Calor no } \\
\text { planeta }\end{array}$ & $\begin{array}{c}\text { Usar menos } \\
\text { energia }\end{array}$ & $\begin{array}{c}\text { Jogar } \\
\text { lixo na } \\
\text { rua }\end{array}$ & $\begin{array}{c}\text { Entupir bueiros } \\
\text { e causa } \\
\text { enchentes }\end{array}$ & $\begin{array}{c}\text { Reciclar o } \\
\text { lixo e não } \\
\text { jogar lixo na } \\
\text { rua }\end{array}$ \\
\hline $\begin{array}{c}\text { Fumaça dos } \\
\text { carros }\end{array}$ & Respiração & $\begin{array}{c}\text { Andar mais a } \\
\text { pé e bicicleta }\end{array}$ & $\begin{array}{c}\text { Poluição } \\
\text { do ar } \\
\text { com a } \\
\text { fumaça }\end{array}$ & $\begin{array}{c}\text { Doenças } \\
\text { respiratórias }\end{array}$ & $\begin{array}{c}\text { Andar mais } \\
\text { de bicicleta } \\
\text { ou a pé }\end{array}$ \\
\hline Desmatamento & $\begin{array}{c}\text { Falta de } \\
\text { oxigênio }\end{array}$ & $\begin{array}{c}\text { Economizar } \\
\text { papel }\end{array}$ & $\begin{array}{c}\text { Matar } \\
\text { animais }\end{array}$ & $\begin{array}{c}\text { Desequilíbrio } \\
\text { do ecossistema }\end{array}$ & $\begin{array}{c}\text { Não matar } \\
\text { animais }\end{array}$ \\
\hline
\end{tabular}

\section{(d) Atividades pós-exibição}

\section{Atividade 7: Recontar a história}

O recontar da história do desenho animado Меи corpo, meu mundo teve como objetivo identificar na fala dos alunos como eles iriam empregar a palavra ecossistema. Os alunos foram convidados a escolher uma cena decupada e impressa do desenho e que continha no verso três palavras-chaves, conforme os exemplos apresentados no quadro 17.

Após a escolha da cena, os alunos eram solicitados a visualizar o verso da cena, no qual se encontravam as palavras-chaves que seriam utilizadas por eles no recontar da história.

Nesse momento, o aluno deveria empregar as palavras-chaves. Vale ressaltar que em todas as cenas havia sido empregada a palavra ecossistema. A atividade ocorreu uma semana após a exibição da primeira sessão de desenho animado apresentada à turma. Cada momento de recontar a história individualmente durou em média de dez a quinze minutos.

O uso das palavras-chaves teve o intuito de contribuir para a rememoração e a organização do pensamento dos alunos para recontar a história, por esse motivo, a ordem das palavras-chaves que aparecem no verso da cena decupada seriam desconsideradas nas falas dos alunos. 
Quadro 17. Exemplo de cenas decupadas, imagens e palavras-chaves referentes à Atividade 7.

\begin{tabular}{|c|c|c|}
\hline $\begin{array}{c}\text { Cena decupada por } \\
\text { minuto }\end{array}$ & Imagem & Palavras-chaves \\
\hline $1{ }^{\prime} 00$ & 7 & UNIVERSO \\
PLANETA TERRA & \\
\hline & &
\end{tabular}

Além disso, a atividade também tinha como objetivo verificar se os alunos iriam citar outros conceitos ${ }^{121}$ abordados durante a narrativa do desenho, conforme o quadro 2, apresentado no Capítulo 4. As ideias mais citadas, por quatro alunos cada uma, foram o mosquito da dengue e os aterros sanitários, estes últimos designados pelos alunos como lixão. Em menor número, apresentam energia, citada por três alunos, seguida por gás natural, petróleo, enchentes, engarrafamento e gás carbônico, todas citadas por dois alunos cada uma.

Pode-se observar na atividade que os alunos ampliaram o vocabulário e foram mais detalhistas ao recontar da história do que ao elaborar o texto na atividade de contar a história. Este fato baseia-se na comparação do número de palavras (59 - 432), na riqueza de detalhes e na sequência lógica em que aconteceram os fatos na narrativa do desenho. Acredita-se que esse fato pode ter ocorrido em função dos recursos disponibilizados como a imagem impressa e as palavras-chaves e das atividades em que ocorreram a reexibição do desenho animado com momentos de pausa e as interações dialógicas da mediação pedagógica realizada entre a entrevistadora e os alunos.

Ao contrário da linguagem escrita, citada anteriormente, a linguagem falada é mais rica e desenvolvida, além do fato de ambas se diferirem na estrutura e no modo de funcionamento. Vigotski (2009, p. 315) observa que a linguagem falada "cria a cada

\footnotetext{
${ }^{121}$ Caso as palavras-chave coincidissem com os conceitos, estes últimos seriam desconsiderados na análise.
} 
minuto a motivação de cada nova flexão da fala, da conversa, do diálogo" e a compara com a linguagem escrita:

Na linguagem falada não há necessidade de criar motivação para a fala. Neste sentido, a linguagem falada é regulada em seu fluxo por uma situação dinâmica que decorre inteiramente dela e transcorre segundo o tipo de processos motivados pela situação e condicionados pela situação. Na linguagem escrita nós mesmos somos forçados a criar a situação, ou melhor, a representá-la no pensamento. Em certo sentido, o emprego da linguagem escrita pressupõe uma relação com a situação basicamente diversa daquela observada na linguagem falada, requer um tratamento mais independente, mais arbitrário e mais livre dessa situação (VIGOTSKI, 2009, p.315).

Por haver essa diferença entre a linguagem escrita e a falada, foi possível observar mais prolixidade no ato de recontar a história em comparação com a contação da história.

Vigostski (2009, p. 313) reitera que "a linguagem escrita difere da falada da mesma forma que o pensamento abstrato difere do pensamento concreto".

Além disso, a situação dinâmica exigida da criança na linguagem escrita é arbitrária e, na linguagem falada, o pronunciamento da fala é automático. Segundo Vigotski (2009), esta questão é o motivo central da linguagem escrita:

\begin{abstract}
A forma sonora da palavra, que na fala é pronunciada automaticamente, sem decomposição em sons particulares, tem de ser decomposta na escrita. Ao pronunciar qualquer palavra, a criança não se dá conta dos sons que emite e nem realiza nenhuma operação ao pronunciar cada som separadamente. Na escrita, ao contrário, ela deve ter consciência da estrutura sonora da palavra, desmembrá-la e restaurá-la voluntariamente nos sinais escritos (VIGOTSKI, 2009, p. 315-316).
\end{abstract}

Em relação ao emprego do conceito de ecossistema, os alunos não conseguiram explicá-lo, mas a maioria tomou consciência de que a sua definição inicial estava incoerente com a do desenho. Os alunos A2F12, A4M11, A7F11 e A9F11 reconheceram um atributo do conceito (a interdependência entre os seres vivos), conforme apresentado a seguir nos trechos transcritos: 
"Agora eu lembrei, tipo uma torre de baralho que se você tirar uma, ela cai. Igual os animais, se tirar um, não vão ter os outros animais, porque um depende do outro. Eu acho que é isso." (A2F11)

"Quando ele volta, ele fala do ecossistema. Ele mostrou o baralho, que se tirar uma peça, vai desequilibrar, um depende do outro." (A4M11)

"É tudo aquilo que precisa para sustentar o outro. Tipo, preciso do tomate para alimentar a vaca, para a vaca dar o leite, fazer o pão, o pão alimentar a gente. Ecossistema para mim é isso agora." (A7F11)

"Isso ele explica o que é ecossistema, que se um não colaborar, tudo não vai dar certo" (A9F11)

Para Vigotski, a tomada de consciência é um modo de agir motivado por uma ação externa:

A tomada de consciência não surge como um degrau superior e necessário no desenvolvimento a partir de conceitos nãoconscientizados, mas é trazido de fora. Um modo de agir simplesmente desloca o outro. Como a cobra lança fora a pele velha para cobrir-se de outra nova, a criança lança fora e abandona o modo anterior de pensamento porque este dá lugar a um novo (VIGOTSKI, 2009, p. 282).

Nesse caso, pode-se considerar que o modo de agir dos alunos (o seu pensamento) para a tomada de consciência foi motivado por uma ação externa caracterizada pela exibição do desenho e pela mediação pedagógica da entrevistadora.

Aparentemente, o primeiro contato dos alunos com o termo ecossistema ocorreu na sessão 1, na qual o conceito foi apresentado na narrativa, em que eles puderam confrontar os conceitos cotidianos explicitados anteriormente com a definição transmitida pelo desenho. Segundo Vigotski (1997, p. 50), “é consciente o que se transmite a outros sistemas em qualidade de excitante e provoca neles uma resposta. A consciência é sempre um eco, um aparato de resposta" e em outra obra, o autor complementa a definição de consciência que "sempre representa algum fragmento da realidade" (VIGOTSKI, 2009, p. 288).

Então, quais foram os meios para a criança passar de um conceito não conscientizado para um conceito conscientizado? É uma das questões levantadas por Vigotski, a qual cabe discutir neste momento em que os conceitos não conscientizados passaram a ser conscientizados. 
O desenvolvimento da consciência envolve a interdependência das funções psíquicas superiores como a memória, a atenção e a percepção. É um processo integral que depende da mudança do todo e não das funções em separado. A estrutura da consciência se modifica ao longo do processo de desenvolvimento infantil e uma das características da criança na idade escolar é marcada pela transição das funções elementares para as funções superiores:

O centro da atenção na idade escolar é ocupado pela transição das funções inferiores da atenção e de memória para as funções superiores da atenção arbitrária e da memória lógica. Já tivemos oportunidade de esclarecer de modo bastante minucioso que estamos autorizados a falar tanto de atenção arbitrária quanto de pensamento arbitrário; de igual maneira, estamos autorizados a falar de memória lógica e de atenção lógica. Isto se deve ao fato de que a intelectualização das funções e a assimilação destas são dois momentos de um mesmo processo de transição para as funções psicológicas superiores. Dominamos uma função na medida em que ela se intelectualiza (VIGOTSKI, 2009, p.282-283).

Quando a criança intelectualiza essas funções, ela começa a perceber os objetos e fenômenos de um modo diferente e modifica as possibilidades de agir em relação a eles. Segundo Vigotski (2009, p. 289-290), “ao generalizar meu próprio processo de atividade, ganho a possibilidade de outra relação com ele". Quando ocorre a tomada de consciência, aparece a discriminação e, consequentemente, a generalização que conduz à apreensão do conceito:

Desse modo, a tomada de consciência se baseia na generalização dos próprios processos psíquicos, que redunda em sua apreensão. Nesse processo manifesta-se em primeiro lugar o papel decisivo do ensino. Os conceitos científicos - com sua relação inteiramente distinta com o objeto -, mediados por outros conceitos - com seu sistema hierárquico interior de inter-relações -, são o campo em que a tomada de consciência dos conceitos, ou melhor, a sua generalização e a sua apreensão parecem surgir antes de qualquer coisa (VIGOTSKI, 2009, p. 290).

O processo manifesta-se em situações de ensino no momento em que o conceito científico é destacado do sistema de relações entre os conceitos e a criança é colocada em uma relação imediata com o objeto. Para Vigotski (2009), o conceito científico faz parte de um sistema de relações entre outros conceitos e apenas neste sistema ele pode tornar-se conscientizado e isso constitui o núcleo da hipótese apresentada a seguir pelo autor: 
[...] só no sistema o conceito pode adquirir as potencialidades de conscientizáveis e a arbitrariedade. A potencialidade de conscientizável e a sistematicidade são, no sentido pleno, sinônimos em relação aos conceitos exatamente como a espontaneidade, a potencialidade de não conscientizável e a não-sistematicidade são três expressões diferentes para designar a mesma coisa na natureza dos conceitos infantis (VIGOTSKI, 2009, p. 291, grifo do autor).

A tomada de consciência sendo considerada generalização, como citada anteriormente, pressupõe a existência de conceitos correlacionados a um conceito superior. Ao mesmo tempo, o conceito superior pressupõe um sistema de hierarquização e os vínculos existentes entre eles dentro do sistema de relações que foi estabelecido. Vigotski (2009) reitera o motivo de a generalização significar tomada de consciência:

Desse modo, a generalização de um conceito leva à localização de dado conceito em um determinado sistema de relações de generalidade, que são os vínculos fundamentais mais importantes e mais naturais entre os conceitos. Assim, generalização significa ao mesmo tempo tomada de consciência e sistematização de conceitos (VIGOTSKI, 2009, p. 292).

Entretanto, a criança só toma consciência daquilo que ela já dispõe, ou seja, os conceitos infantis desenvolvidos (bastante ricos e maduros), para que se tornem objetos tanto do ato consciente quanto da sistematização. Com base nos dados gerados do presente estudo, pode-se supor que a tomada de consciência ocorreu a partir do contato com a definição de ecossistema apresentada na narrativa do desenho animado e a mediação pedagógica, que caracteriza a ação externa explicitada por Vigotski e citada anteriormente.

Quando eles não empregavam a palavra ecossistema ao recontar a história, a entrevistadora os questionava a respeito do que entendiam sobre o que era ecossistema. Alguns alunos admitiram que não sabiam responder, por exemplo: "Que o ecossistema é...Não sei" (A3M12), ou não lembraram, por exemplo, "Eu não lembro...Ele começa a falar... O planeta Terra cai, ele vai buscar o planeta. Eu não lembro, não. E ele fala 'olha o macarrão', e ele falou 'o que?'. Não lembro.”(A11F12).

Porém, somente o aluno A5M10 manteve a sua definição inicial como sendo "A natureza" e reiterou que ecossistema consistia no conceito apresentado pelo aluno A0M10b, mas não soube explicar o que ele afirmava ser um ecossistema. O aluno A5M10 não assimilou o novo conceito e manteve o seu modo de pensamento, ou seja, continuou a operar com os conceitos cotidianos (pensamento sincrético) elaborados a partir da sua experiência e interação social, o que evidencia que, na aprendizagem de conceito científico, não basta uma simples apresentação do conceito vigente. 
Para Vigotski (2009, p. 228), as formas mais antigas convivem com as formas mais recentes do comportamento, assim como o desenvolvimento do pensamento infantil. O autor explica como isso ocorre ao comparar as formas elementares de pensamento (sincretismo) com as formas superiores de pensamento (pensamento conceitual):

[...] mesmo depois de ter aprendido a operar com forma superior de pensamento - os conceitos -, [...] não abandona as formas mais elementares, que durante muito tempo ainda continuam a ser qualitativamente predominantes em muitas áreas do seu pensamento (VIGOTSKI, 2009, p. 228).

De acordo com Vigotski (1997, p. 186), o pensamento infantil possui o caráter sincrético "o pensamento em situações íntegras, por parte inteiras ligadas entre si, estão tão firmes que perdura todavia no escolar na esfera do pensamento verbal”. A criança manifesta uma incapacidade em perceber os objetos separadamente, pois "a percepção e a ideia sobre o mundo depende da situação" (VYGOTSKY, 1997, p. 190, tradução nossa).

No caso do aluno A5M10, a não consciência dos conceitos e a dificuldade de abstração dos atributos do conceito em questão pode ser explicada pelo seu modo de pensamento ainda operar com o sincretismo, ou seja, com base na percepção imediata da criança em relação aos objetos ou elementos da situação em questão.

Acredita-se que algumas cenas do desenho contribuíram para confundir os alunos. As hipóteses para tanto se baseiam especificamente em duas cenas: a primeira cena refere-se ao momento em que Prof. Lecré utiliza a mesma imagem do globo terrestre para mostrar o convívio harmônico entre os seres vivos e para apresentar o gás natural, o petróleo e o conceito de ecossistema. A outra se refere à cena em que o Prof. Lecré mostra a pirâmide de baralho para fazer uma analogia com o que ocorria no ecossistema, caso ocorresse o desequilíbrio. A seguir, os trechos que apresentam esses fatos:

"Falou do gás carbônico, que faz o plástico, que é chamado de ecossistema." (A1F12)

"Que o ecossistema tem a ver com o gás lá. Que é do gás lá em baixo, que eles pegam da terra para levar." (A8M10)

Outra observação durante o ato de recontar a história refere-se às definições utilizadas pelos alunos, que não explicitavam o termo ou a palavra que as designavam de fato. Por exemplo, a expressão "impermeabilização do solo" foi explicada de 
diversas maneiras, no entanto, a expressão em si não foi citada, somente o seu significado. Abaixo, têm-se os trechos transcritos que explicitam esse fato:

"Jogaram o cimento em cima da calçada e fizeram um buraco para a água descer." (A5M10) (Referindo-se aos bueiros construídos para a canalização da água)

"Mostrou o Fulano de Tal, que ele estava fazendo uma obra. E ele estava querendo pegar cimento e colocar sobre a superfície do solo, para formar... Só que ia formar enchentes, um montão de coisa." (A6F11)

"Por causa do cimento que não fez a água descer mais" (A8M10)

"Aí o Fulano de tal, estava chovendo, a água que entrava na terra, ele foi e passou o cimento por dentro e não botou... E a água não entrava mais para a terra, aí tinha que achar um bueiro para poder passar aquela água toda." (A9F11)

Os alunos operaram com o significado da palavra e não com a palavra em sua acepção, no caso, a expressão. Na Linguística Moderna, a palavra é composta por dois componentes que se desdobram em funções: a representação material e o significado da palavra. A primeira função é a representação material, que permite "ao homem evocar arbitrariamente as imagens dos objetos correspondentes" e a segunda, o significado da palavra, que permite "analisar os objetos, distinguir nestes as propriedades essenciais e relacioná-los a determinada categoria” (LURIA, 1994c, p. 19).

Segundo Vigotski (2009, p. 210), as palavras das crianças coincidem com as dos adultos em sua referencialidade concreta (representação material), mas não coincidem em seu significado. $\mathrm{O}$ autor destaca que a coincidência da representação material é uma peculiaridade do pensamento infantil por complexos, mas o modo como a criança concebe é diferente do adulto:

[...] a criança concebe como significado da palavra o mesmo que concebe o adulto, ou seja, concebe aqueles referentes graças aos quais a comunicação se torna possível, mas concebe o próprio conteúdo de modo bem diferente e por intermédio de operações intelectuais bem diferentes(VIGOTSKI, 2009, p. 210).

O emprego da palavra é aplicado de modo diferente se comparado à operação com conceitos (pensamento abstrato). É essa diferença que permite uma análise da evolução do pensamento infantil nos diferentes “estágios” (VIGOTSKI, 2009). 


\section{Atividade 8: Relações ecológicas do Cerrado}

O desenho animado Aventuras com os Kratts (EUA, 2011) - episódio Cadeia Alimentar - foi exibido na sala de aula para criar uma situação de aprendizagem na realização da atividade 9 e para os alunos perceberem o habitat natural dos seres vivos citados (hipopótamos, guepardos e leões) em atividades anteriores.

Após a exibição com a duração de aproximadamente vinte e um minutos, levantaram-se os seguintes questionamentos: Vocês gostaram do desenho? Vocês saberiam me dizer em qual ecossistema nós vivemos? Vocês conhecem os animais do Cerrado? Nas duas primeiras questões, os alunos responderam negativamente e, na terceira questão, eles responderam o lobo-guará, animal-símbolo do Cerrado.

Em seguida, entregou-se aos alunos um esquema colorido, que contextualiza os aspectos geográficos referentes ao relevo como o solo, os rios e a inclusão de seres não vivos como o sol, as nuvens e as pedras, o que possibilitaria representar os ecossistemas aquático e terrestre. Em função de a maioria dos alunos não conhecer os animais do Cerrado, optou-se por utilizar uma lista de figuras ${ }^{122}$ de alguns animais desse ecossistema. Após a entrega do esquema e da lista de espécies, solicitou-se aos alunos que elaborassem as relações ecológicas alimentares dessas espécies em um ou nos dois ambientes (terrestre e aquático), de acordo com a sua preferência.

Os alunos utilizaram entre cinco (mínimo) e dezenove imagens (máximo) das vinte e oito presentes na lista disponibilizada. Dos onze alunos, quatro (A3M12, A4M11, A7F11 e A9F11) colocaram as imagens dos seres vivos em seu ambiente natural (aquático ou terrestre). Outros alunos, a exemplo dos alunos A1F12, A2F11, A6F11, A8M10 e A10F10, relacionaram os seres vivos ligando-os com um traço. O aluno A11F12 não os relacionou desta forma, mas dispôs as figuras uma ao lado da outra, na tentativa de indicar a composição linear da cadeia alimentar tanto no ambiente aquático quanto no terrestre. Somente o aluno A5M10 fez o uso de setas sem que fosse orientado para tal. Ao final da atividade, permitiu-se aos alunos que ficassem com as figuras restantes, não utilizadas por eles na atividade.

Outra observação que se pode inferir a partir das cadeias ou teias elaboradas é o fato de todos os alunos disporem o produtor (no caso, a figura da alga) no ambiente aquático. Acredita-se que esse fato tenha ocorrido em função do uso da imagem na atividade de identificação de seres vivos e não vivos, pois, em atividade posterior, dos

\footnotetext{
${ }^{122}$ A lista de figuras dos animais do Cerrado apresenta-se no Quadro 7, no Capítulo 4. Na montagem da cadeia ou da teia alimentar, os alunos foram orientados a optar por manter o nome do ser vivo na figura ou por cortá-lo.
} 
quatro alunos que optaram pelo ambiente aquático, dois deles incluíram a alga como produtor, e também da mediação da entrevistadora ao esclarecer que a alga é um ser vivo, tendo em vista que alguns alunos inicialmente a incluíram no grupo dos seres não vivos na atividade de identificação (3.1).

De maneira geral, os alunos elaboraram mais de uma cadeia alimentar, sendo uma ou duas no ambiente terrestre e uma no ambiente aquático. Assim como na atividade anterior, a principal dificuldade explicitada pelos alunos durante a elaboração da atividade era saber quem se alimentava de quem quanto às espécies do Cerrado que eles não conheciam. A seguir, o quadro 18 apresenta as cadeias e as teias alimentares elaboradas pelos alunos.

Quadro 18. Cadeias ou teias alimentares elaboradas pelos alunos, referentes à Atividade 8.

Aluno




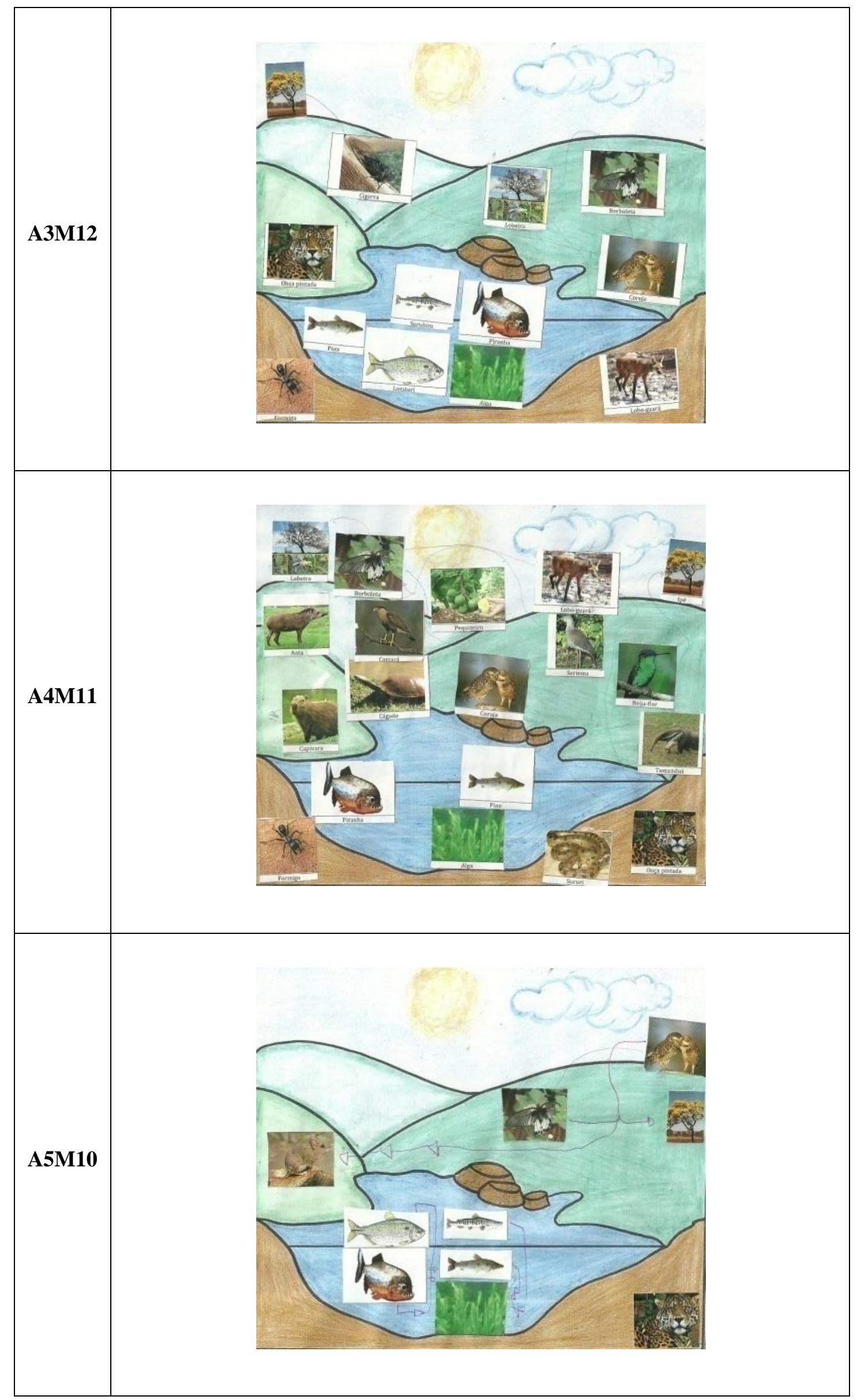




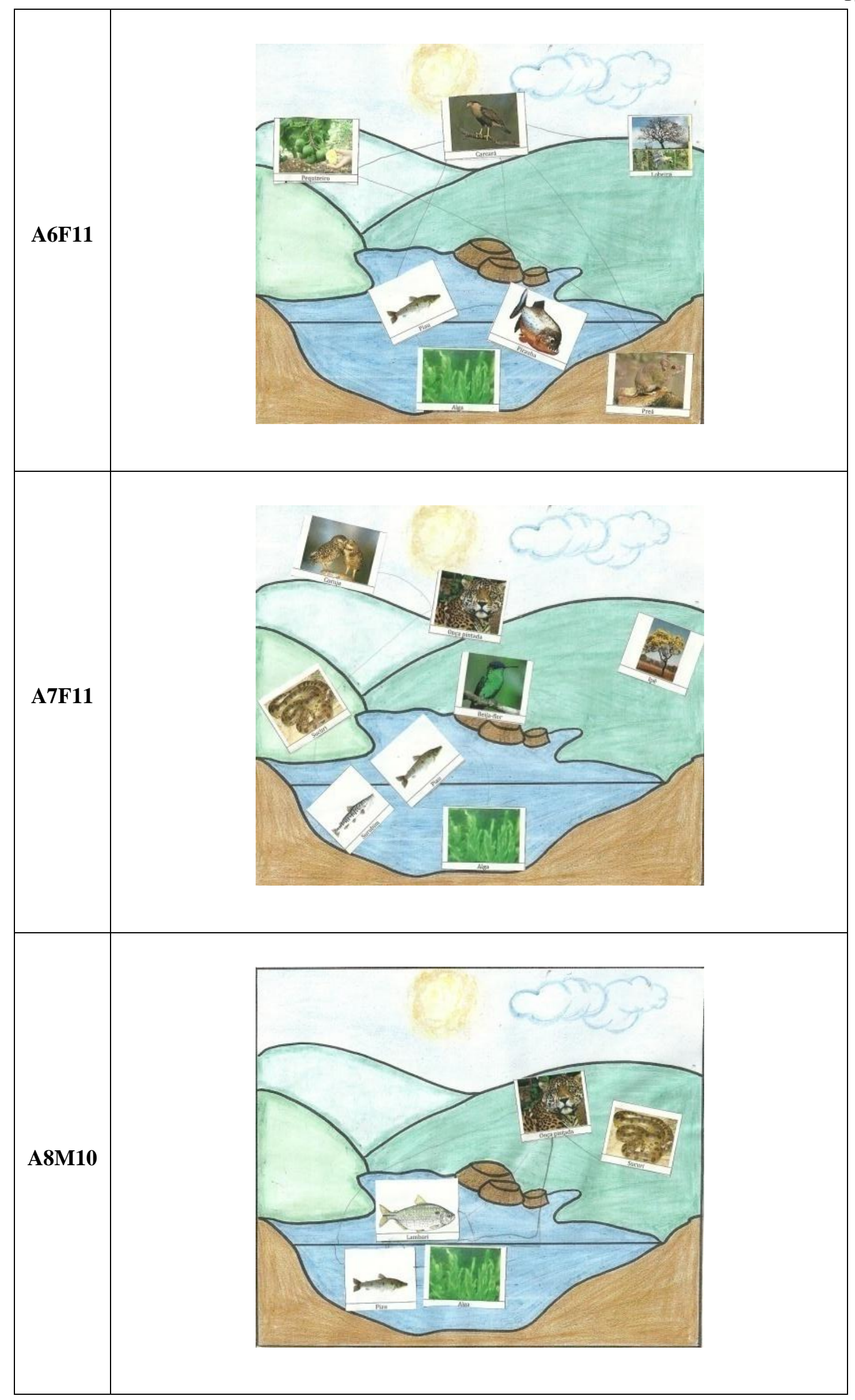




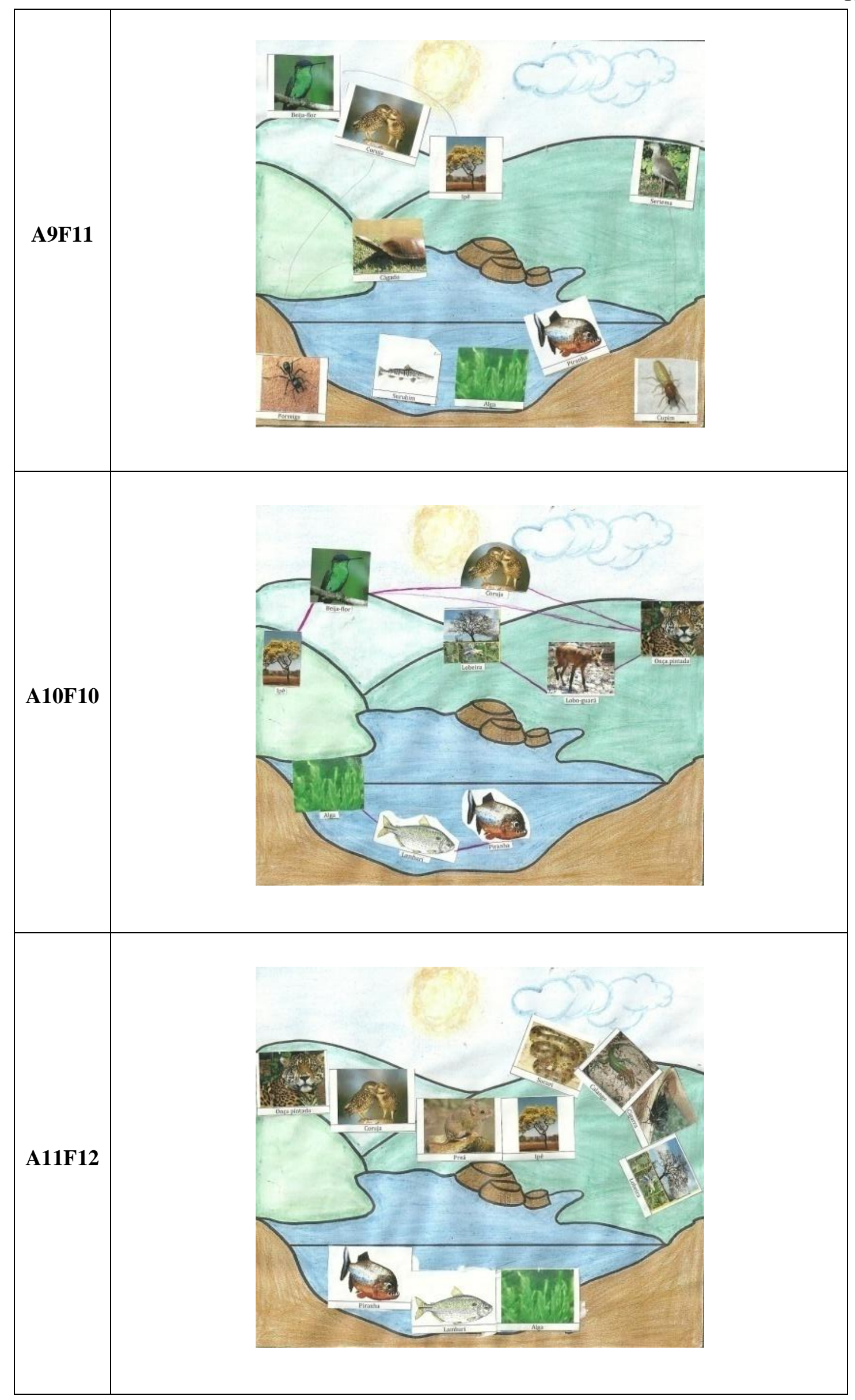




\section{Atividade 9: Entrevista final}

Os esquemas elaborados na atividade anterior foram utilizados na entrevista individual para promover a discussão com base na interação dialógica e investigar como os alunos pensaram para estabelecer as relações ecológicas, além de avaliar a aprendizagem do conceito de ecossistema. A entrevista, semiestruturada, com duração média de quinze a vinte minutos, caracterizada por perguntas abertas, permitiu as interações dialógicas a partir de algumas questões, por exemplo: O que você pensou para montar essas relações entre os seres vivos escolhidos? Você acha que montou uma cadeia alimentar ou uma teia alimentar? Qual a diferença entre elas? Você acha que seu desenho poderia representar um ecossistema? O que você entende por ecossistema? Como nós, seres humanos, interferimos no ecossistema?

As primeiras ideias elaboradas pelos alunos sobre as relações ecológicas referem-se ao habitat dos seres vivos, dispondo as figuras nas imagens que representavam o solo, o subsolo e a água (A1F12, A3M12, A4M11, A7F11, A9F11) ou às relações que se referiam a quem se alimentava de quem em uma cadeia ou teia alimentar (A2F11, A5M10, A6F11, A8M10, A10F10, A11F12).

As questões antropomórficas de cunho afetivo, estético e de preferências quanto a alimentação foram abordadas pelos alunos no decorrer da entrevista em que eles justificaram ou explicitaram a escolha dos seres vivos utilizados na montagem das relações ecológicas. O trecho subsequente, transcrito da fala do aluno A2F11, ao responder a um questionamento da entrevistadora, classifica-se em um bom exemplo:

E: E o preá come o quê?

A2F11: O preá come...ai sei lá, acho que ele come queijo!

E: Você acha que ele come queijo?

A2F11: É!

E: Por quê?

A2F11: É porque todo rato come queijo! Aí ele parece muito com rato, eu acho que é um rato, o preá! Eu acho que é um rato!

E: Sim, já ouviu falar do porquinho-da-índia?

A2F11: Já.

E: Ele é um porquinho-da-índia ou preá!

A2F11: Ah!

E: Tem vários nomes, tá! Então essa ideia que a gente tem dos ratos comerem queijos, ela vem muito de desenhos animados, né?

A2F11: É

E: Na verdade ele come plantas!

A2F11: É

E: Por exemplo, milho, plantas! (Sobre a alimentação do preá)

O trecho acima é um exemplo da influência cultural (disseminação de imagens em movimento, por exemplo, de desenhos animados) e da interação social que 
estabelece determinadas representações (ratos comem queijos). Porém, não se pode esquecer que os animais domesticados mudam os hábitos alimentares, sendo possível uma dieta alimentar bastante variada. No exemplo supracitado, o preá é um animal herbívoro e a sua alimentação é composta por plantas como capim, legumes e frutas.

Novamente, os conceitos relacionados à cadeia alimentar como carnívoro, herbívoro, produtor e onívoro foram discutidos e explicitados durante a entrevista. Alguns alunos, a exemplo do A11F12, operaram com o conceito de carnívoro e herbívoro, outros identificaram as cadeias elaboradas no esquema e conseguiram estabelecer as relações entre os seres vivos quando foram solicitados para tal. O aluno A2F11 apresentou a mesma definição para cadeia alimentar e para ecossistema.

De acordo com a perspectiva da teoria histórico-cultural, o pensamento conceitual é o terceiro estágio de desenvolvimento do pensamento infantil em que são desenvolvidas a decomposição, a análise e a abstração. Nesta atividade, manifestou-se o segundo estágio de desenvolvimento do pensamento conceitual: os conceitos potenciais - a criança destaca um grupo de objetos que depois será generalizado por ela segundo um atributo comum (VIGOTSKI, 2009). A maioria dos alunos identificou um atributo do conceito - a interdependência entre os seres vivos.

Os conceitos potenciais desempenham um papel relevante no desenvolvimento do pensamento infantil, que consiste em:

[...] pela primeira vez, abstraindo determinados atributos, a criança destrói a situação concreta, o vínculo concreto dos atributos e, assim, cria a premissa indispensável para uma nova combinação desses atributos em nova base. Só o domínio do processo da abstração, acompanhado do desenvolvimento do pensamento por complexos, pode levar a criança a formar conceitos de verdade (VIGOTSKI, 2009, p. 226).

A abstração é uma função especial superior necessária ao verdadeiro processo de formação de conceito. Partindo desse pressuposto, somente o domínio dessa função no pensamento infantil permite abstrair os atributos e sintetizá-los, para operar com o conceito em determinada situação. De acordo com Vygotsky e Luria (1996, p. 202), “o processo de abstração só se desenvolve com o crescimento e com o desenvolvimento cultural da criança; o desenvolvimento desta está intimamente ligado ao início do uso de ferramentas externas e à prática de técnicas complexas de comportamento”.

Os conceitos potenciais podem ser confundidos com os pseudoconceitos em função da semelhança e da aparência funcional, mas diferem entre si quanto à sua natureza (VIGOTSKI, 2009, p. 222). O pseudoconceito, por ser um estágio de transição 
entre pensamento por complexos e o pensamento conceitual, é extremamente instável, cede seu lugar a outro atributo e não apresenta, de forma alguma, um atributo privilegiado.

Além dos conceitos supracitados, há os conceitos potenciais, em que "o atributo que serve de base à inclusão do objeto em um grupo comum é um atributo privilegiado, abstraído do grupo concreto de atributos aos quais está efetivamente vinculado" (VIGOTSKI, 2009, p. 225). Por esse motivo, pode-se considerar que os alunos operaram com conceitos potenciais ao definirem ecossistema durante a entrevista final, considerando o fato de terem abstraído um atributo deste conceito.

Além disso, as ações antrópicas foram discutidas durante a entrevista em forma de questionamentos: Como nós, seres humanos, interferimos nesse ecossistema? Qual o impacto para o meio ambiente se eu construísse uma cidade no meio desse ecossistema? Quais seriam os outros impactos?

Segue o trecho da entrevista do aluno A7F11 que apresenta a discussão:

E: E se eu tirasse...tirasse aqui, vamos supor aqui no...no seu esquema, tirasse a onça, o que aconteceria?

A7F11: É, ...ai, ai.

E: Uma vez você me explicou isso muito bem! Acho que você não está lembrando! O que aconteceria se eu tirasse...

A7F11: Ah, haveria um desequilíbrio na cadeia alimentar.

E: Hum, muito bem! E aí poderia...o que poderia acontecer nesse desequilíbrio? sobreviver.

A7F11: Ia acabar morrendo todos aos poucos porque não ia ter mais para os outros

E: Hum, no caso aqui se eu tirasse a onça pintada, por exemplo, os herbívoros que são os animais que a onça pintada se alimenta, eles iam aumentar muito, ia comer muita planta.

A7F11: E não ia ter mais planta, não ia sobrar mais planta para eles comerem. Então vai ter muita pouca planta e eles vão acabar morrendo.

E: Exatamente, ia haver uma competição por essas plantas, não é?

A7F11: Humrum (sinaliza positivamente com a cabeça)

E: Então iria aumentar muito a população e ia acontecer isso que você acabou de falar. Exatamente! E no caso, no nosso caso, seres humanos, como os seres humanos interferem nesse ecossistema?

A7F11: Matando os animais.

E: Matando os animais. Você teria outros exemplos para me explicar?

A7F11: Hum, é, cortando as árvores

E: Cortando as árvores que servem de abrigo. E se eu construísse uma cidade aqui no meio desse ecossistema?

A7F11: A onça não ia ter lugar para ela ficar, a cobra também não, aí elas iam acabar indo pra aquelas aqui e eles iam acabar matando eles.

As respostas dos alunos referentes aos questionamentos supracitados sobre as ações antrópicas se repetiram no que diz respeito ao desequilíbrio, à ocupação dos habitats pelas cidades, às queimadas e à poluição. 
Outros alunos, a exemplo do aluno A6F11, explicitaram ideias equivocadas justificando "porque alguns animais não podem comer a gente", quando questionados pela entrevistadora sobre como os seres humanos interferem no ecossistema.

A seguir, o quadro 18 apresenta um comparativo das definições do termo ecossistema apresentadas pelos alunos nas atividades desenvolvidas no período de préexibição e de pós-exibição do desenho animado Meu corpo, meu mundo.

A antiga psicologia supunha que a formação de conceitos na criança ocorria pelo aumento de vínculos associativos ao longo do desenvolvimento infantil. Na perspectiva da teoria histórico-cultural, o processo de formação de conceitos ocorre com o emprego de signos (palavra) como meio para a realização de operações psicológicas pelas quais o homem domina os processos psíquicos superiores e possibilita a modificação do seu comportamento. A esse respeito, Vigotski (2009) expõe a complexidade do processo:

A formação de conceito ou a aquisição de sentido através da palavra é o resultado de uma atividade intensa e complexa (operação com palavra ou signo), da qual todas as funções intelectuais básicas participam em uma combinação original (VIGOTSKI, 2009, p.168).

Apesar de todas as funções superiores participarem do processo, nenhuma determina o aparecimento de uma nova forma de pensamento (pensamento abstrato ou conceitual). O processo "tem como principal traço distintivo a passagem de processos intelectuais imediatos a operações mediadas por leis" (VIGOTSKI, 2009, p. 173).

O quadro 18 apresenta a maneira como os alunos empregaram a palavra ecossistema desde a primeira atividade, em que tiveram o primeiro contato com o termo, até a última atividade. Ao total, foram realizadas quatro atividades nas quais os alunos foram solicitados a empregar a palavra ecossistema. Estas tarefas foram propostas em uma situação de ensino que motivou os alunos a desenvolverem o pensamento.

É precisamente com o auxílio dos problemas propostos, da necessidade que surge e é estimulada, dos objetivos colocados perante o adolescente que o meio social circundante o motiva e o leva a dar esse passo decisivo no desenvolvimento do seu pensamento (VIGOTSKI, 2009, p. 171).

No caso, a escola é o meio social e desempenha um papel fundamental na proposição de diferentes tarefas para os alunos, estimulando e criando momentos funcionais para desenvolver as formas superiores de pensamento. Por isso, os conceitos 
não podem ser assimilados prontamente e, como afirma Vigotski (2009, p. 247), “o ensino direto de conceitos sempre se mostra impossível e pedagogicamente estéril".

As definições propostas pelos alunos no quadro 19 apresentam um avanço do significado da palavra ecossistema. Antes da exibição do desenho, os alunos explicitam as noções, os conceitos cotidianos que possuem sobre o termo e, após a exibição, eles modificam a relação com a palavra remetendo outro sentido, revelando um dos atributos do conceito.

Neste momento, propõe-se a analisar, a título de exemplo, as definições apresentadas pelo aluno A4M11, que demonstram os diferentes modos de pensamento a partir da suposição do que seria o primeiro contato com a palavra ecossistema e a evolução de seu significado. A concepção inicial definia ecossistema como "O meu ecossistema funciona com um sol, as nuvens, uma borboleta e quatro lixeiras com vidro, papel, plástico e metal aqui é um lugar tranquilo". Esta definição é uma descrição do desenho elaborado pelo aluno sobre o que ele considerou ser um ecossistema. Para Vigotski, o início do processo de formação de conceitos ocorre quando a criança aprende uma palavra nova:

\footnotetext{
Quando uma palavra nova, ligada a um determinado significado, é apreendida pela criança, o seu desenvolvimento está apenas começando; no início ela é uma generalização do tipo elementar que, à medida que a criança se desenvolve, é substituída por generalizações de um tipo cada vez mais elevado, culminando o processo na formação dos verdadeiros conceitos (VIGOTSKI, 2009, p. 246).
}

$\mathrm{Na}$ segunda atividade pré-exibição, a entrevista individual, o aluno A4M11 reafirmou a sua concepção inicial sobre o que era ecossistema, ao afirmar "que era um lugar tranquilo. E os papeis, vidro... Estavam reciclados. E tinha os pássaros voando e as borboletas". Após a apresentação do conceito de ecossistema na narrativa do desenho animado, o aluno A4M11 empregou a palavra ecossistema remetendo-se às cenas do desenho e reelaborou a informação repassada "quando ele volta, ele fala do ecossistema. Ele mostrou o baralho, que se tirar uma peça, vai desequilibrar, um depende do outro". 
Quadro 19. Quadro comparativo das atividades em que o conceito ecossistema foi abordado.

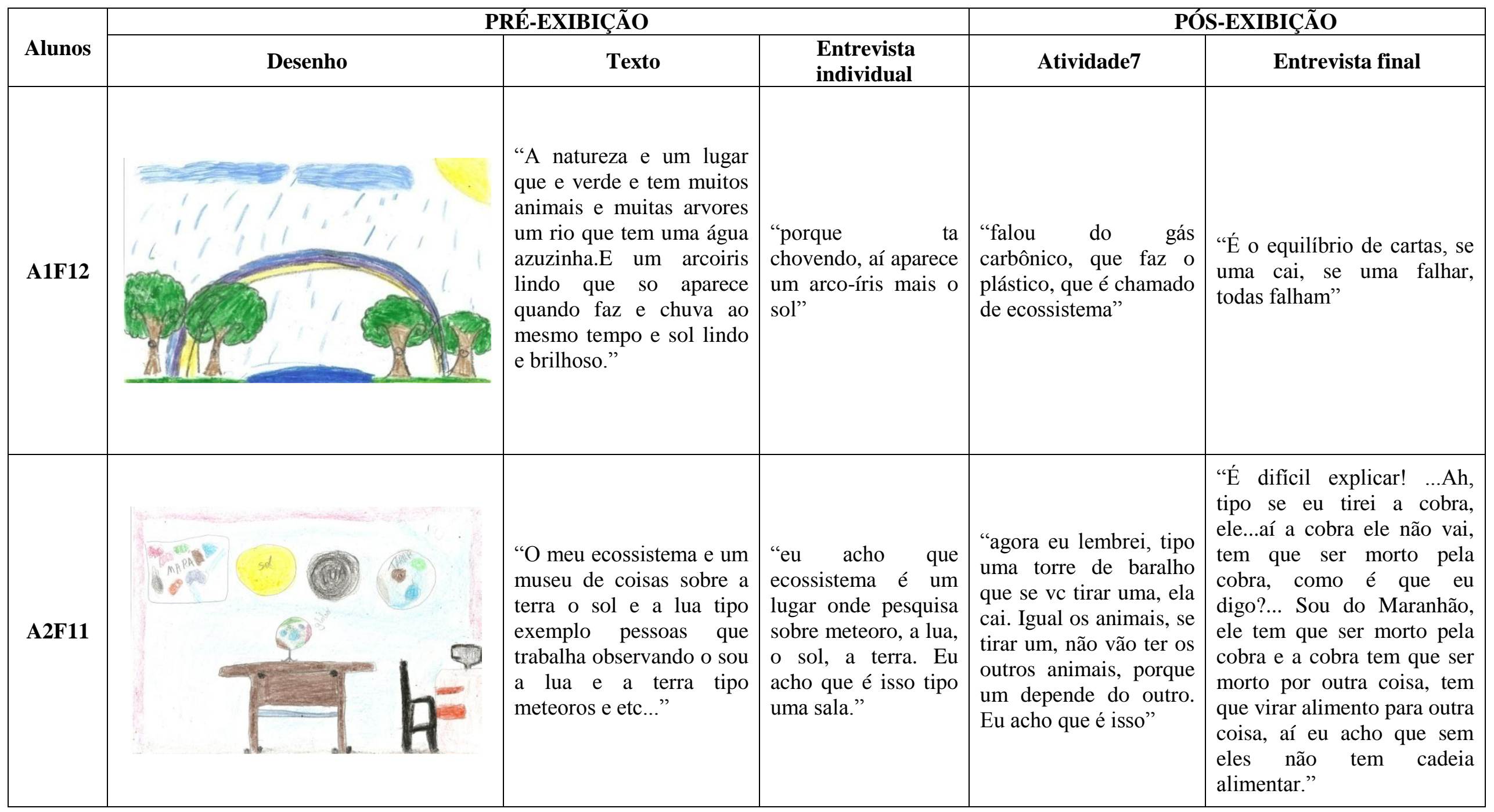




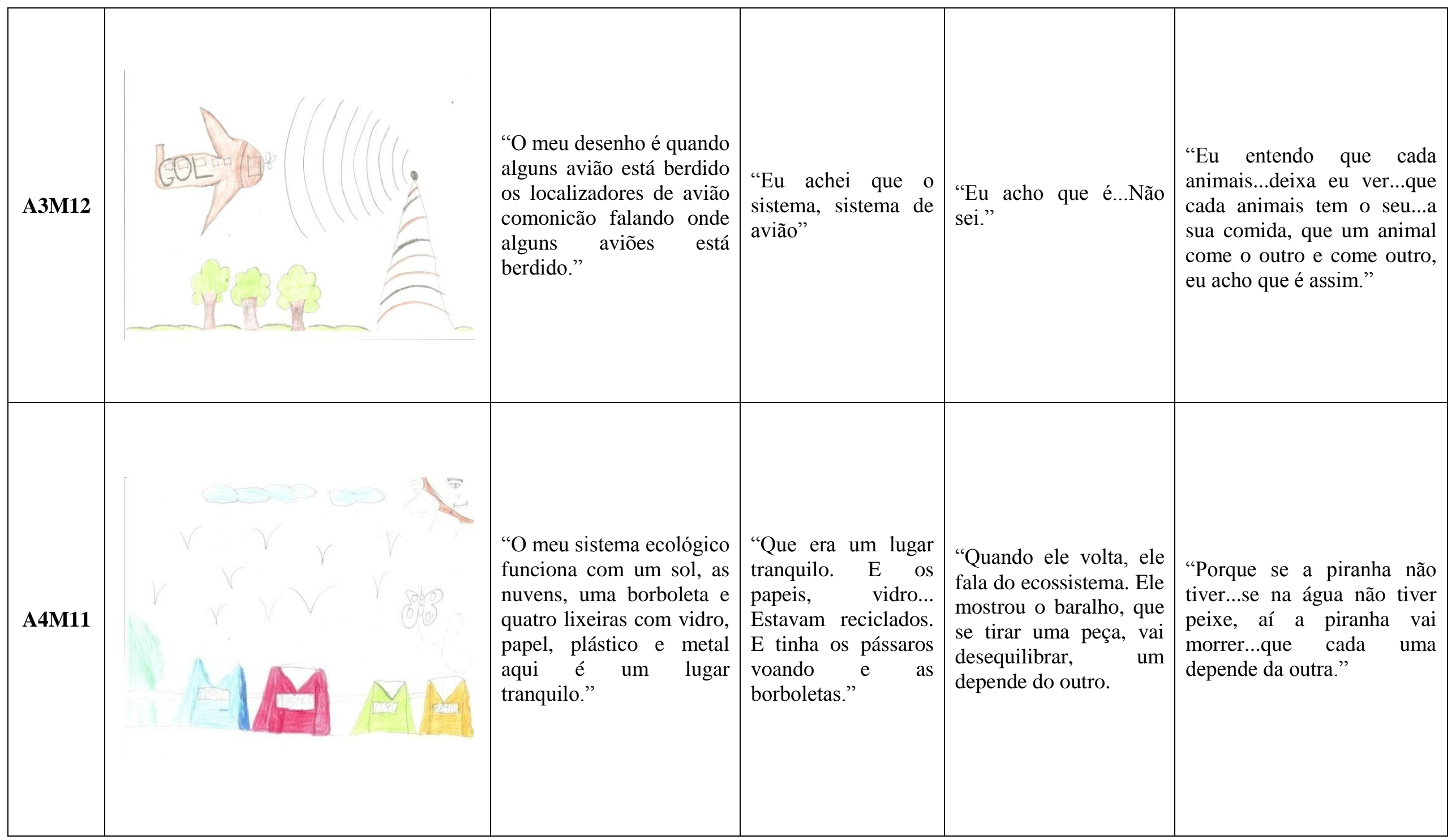




\begin{tabular}{|c|c|c|c|c|c|}
\hline A5M10 & 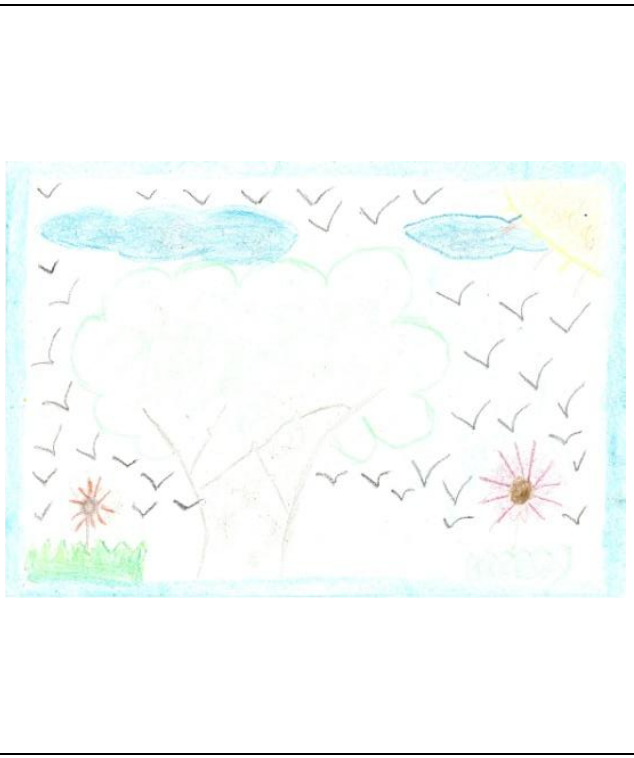 & $\begin{array}{l}\text { "Boa tarde, meu desenho } \\
\text { significa como a natureza } \\
\text { ficaria se não jogassimos } \\
\text { lixo no parque ne uma } \\
\text { praça movimentada, eu } \\
\text { acharia ruim se vinhece } \\
\text { alguma pessoa de outro } \\
\text { país por exemplo: da } \\
\text { Argentina, da Alemanha, } \\
\text { Inglaterra, Espanha, } \\
\text { Estados unidos vinhecem } \\
\text { aqui e fesse um lugar } \\
\text { lindo cheio de lixo eu } \\
\text { acharia ruim, por isso que } \\
\text { eu fiz este desenho } \\
\text { pensando que era um } \\
\text { ecossistema." }\end{array}$ & $\begin{array}{l}\text { "Eu pensei em um } \\
\text { algum lugar que tem } \\
\text { flores, árvores } \\
\text { bonitas, não } \\
\text { estivesse sujo, aí eu } \\
\text { pensei que fosse o } \\
\text { ecossistema", }\end{array}$ & $\begin{array}{l}\text { "A natureza. O que a } \\
\text { Emilly falou, me } \\
\text { esqueci também. Não } \\
\text { lembro não." } \\
\text { (A Emilly afirmou que } \\
\text { ecossistema era sistema } \\
\text { ecológico) }\end{array}$ & $\begin{array}{l}\text { "A lei da natureza igual eu } \\
\text { sempre falo" }\end{array}$ \\
\hline A6F11 & 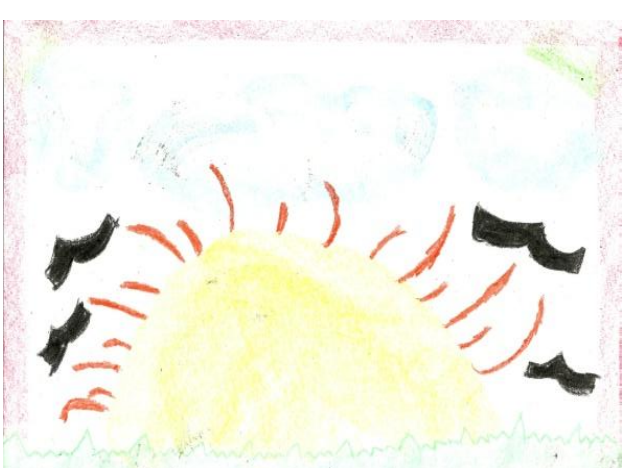 & $\begin{array}{l}\text { "No meu ecossistema tem } \\
\text { muita vida, muito mato, } \\
\text { muita água e muitos ser } \\
\text { vivos ele funciona assim } \\
\text { os pássaros comem as } \\
\text { folhas bebem água aí } \\
\text { começa a cadeia } \\
\text { alimentar e é assim que é } \\
\text { meu ecossistema." }\end{array}$ & $\begin{array}{l}\text { "Eu pensei que esse } \\
\text { era o sistema } \\
\text { ecológico e que eu } \\
\text { pudesse desenhar a } \\
\text { natureza." }\end{array}$ & "Sistema ecológico?" & "Sistema ecológico" \\
\hline
\end{tabular}




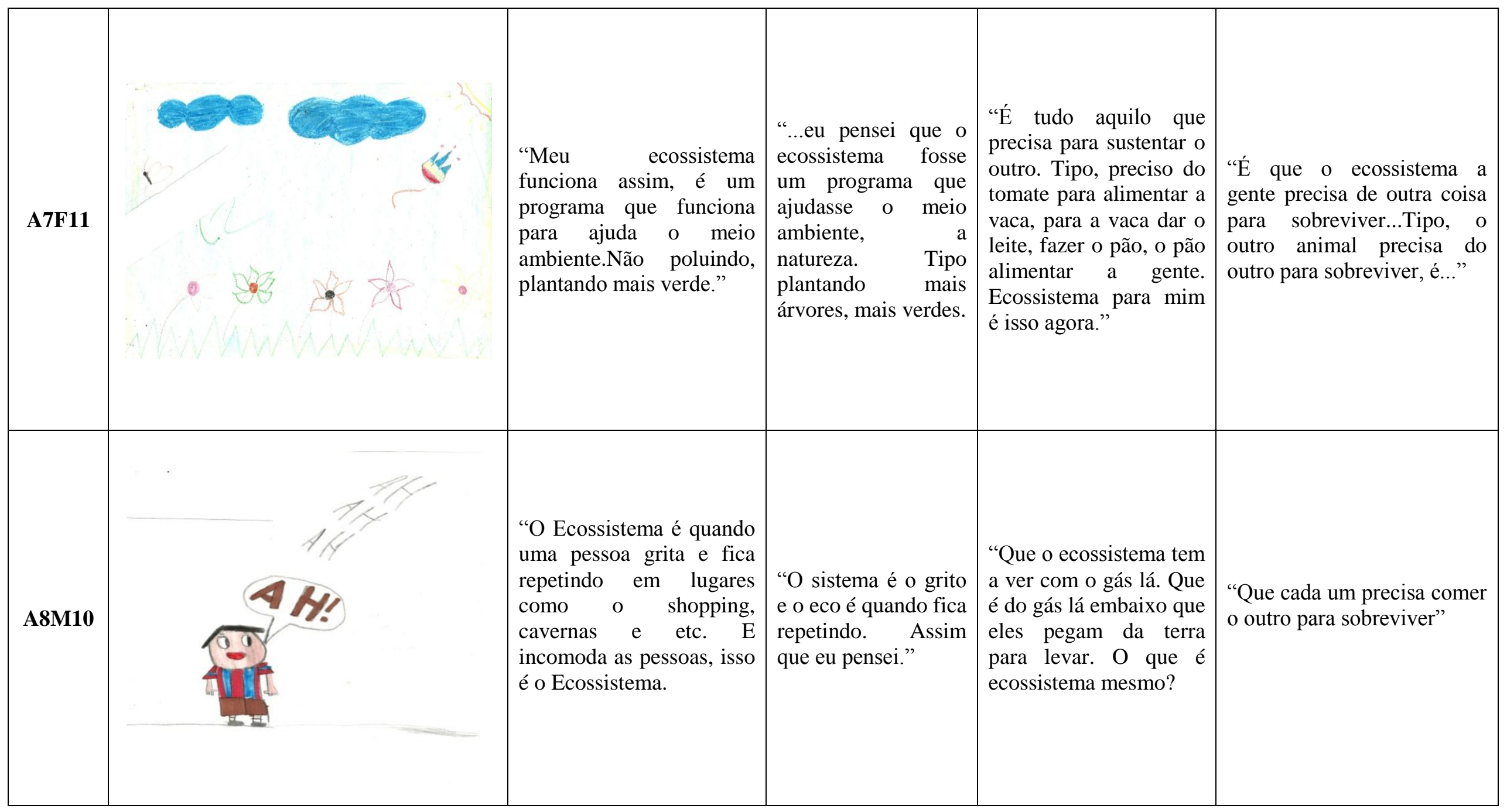




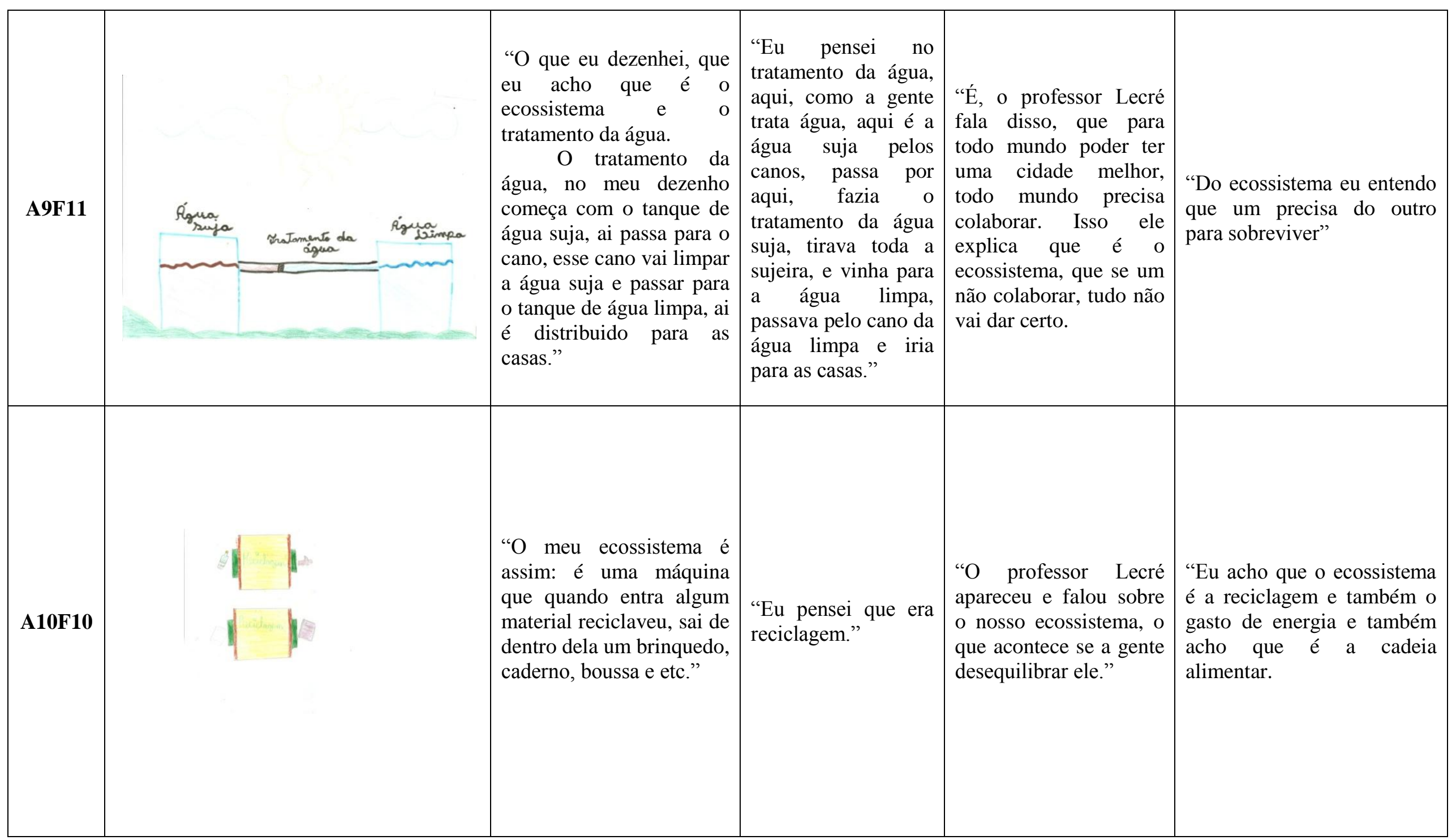




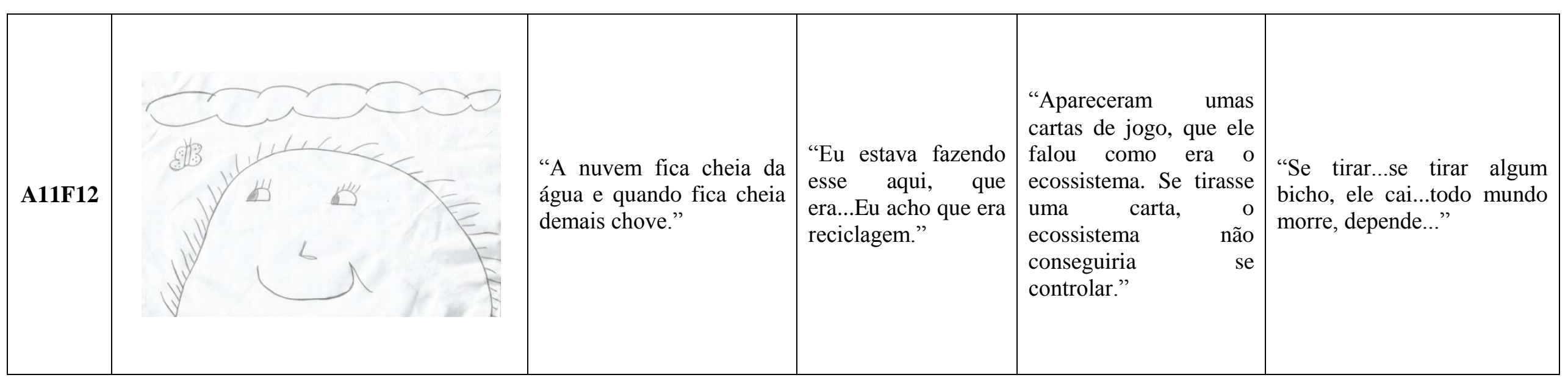


$\mathrm{Na}$ última entrevista, esse aluno conseguiu abstrair um atributo, a interdependência entre os seres, e aplicá-lo em outra situação, como a elaboração das relações ecológicas alimentares em que ele explica o ecossistema utilizando os seres escolhidos na lista de espécies do Cerrado, conforme explicita: "porque se a piranha não tiver...se na água não tiver peixe, aí a piranha vai morrer...que cada uma depende da outra".

A abstração de um atributo denomina-se conceito potencial, ou seja, que se encontra dentro das possibilidades de ainda vir a ser um conceito. Segundo Vigotski (2009, p. 223), “estes são potenciais, em primeiro lugar, por sua referência prática a um determinado círculo de objetos e, em segundo, pelo processo de abstração isoladora que lhe serve de base".

O aluno A4M11, que iniciou o processo explicitando os seus conceitos cotidianos, após o contato com o conceito científico, começou a empregar a palavra com outro sentido e conteúdo, modificando o significado da palavra. Como o processo de formação de conceitos é complexo, os alunos abstraíram um atributo, mas não atingiram a conceptualização.

A esse respeito, cabe salientar que o desenvolvimento do pensamento e a formação de conceitos são mediados pela palavra - signos culturais - que orientam o processo das operações psíquicas decorrentes. Para Vigotski (2009, p. 170), “o conceito é impossível sem palavras", e ainda ressalta que:

[...] o pensamento em conceitos é impossível fora do pensamento verbal; em todo esse processo, o momento central, que tem todos os fundamentos para ser considerado causa decorrente do amadurecimento de conceitos, é o emprego específico da palavra, o emprego funcional do signo como meio de formação de conceitos (VIGOTSKI, 2009, p. 170).

Os resultados gerados no presente estudo demonstram que o emprego da palavra teve um papel fundamental na orientação do processo de formação de conceitos e que o pensamento dos alunos está em pleno desenvolvimento, podendo os tipos de pensamento coexistir durante o desenvolvimento do processo de formação de conceito corroborando os pressupostos teóricos adotados. 


\section{CAPÍTULO 6}

\section{AS TRAJETÓRIAS CONTINUAM ANIMADAS...}

O título faz jus ao complexo processo de formação de conceito, que implica tanto os tipos de conhecimentos quanto as diferentes relações sociais entre alunos e professores no momento de elaboração do conhecimento. Considera-se importante resgatar as trajetórias trilhadas neste estudo, que teve como objetivo geral analisar em que medida os alunos dos Anos Iniciais do Ensino Fundamental ( $5^{\circ}$ ano) se apropriaram das informações científicas apresentadas na narrativa do desenho animado Мeu corpo, Meu mundo e como essas informações são articuladas na formação do conceito de ecossistema.

Assim, pretende-se pontuar os aspectos relevantes para a proposta deste estudo, como o conceito ecossistema, o emprego da palavra e a relação com outros conceitos, a metodologia empregada na pesquisa referente às imagens fixas e ao desenho animado, a mediação pedagógica realizada entre os alunos e a entrevistadora e, por fim, as contribuições e as limitações do trabalho e, assim, apontar outras "trajetórias".

A partir dos conceitos cotidianos sobre o tema ecossistema, foi possível identificar os conhecimentos prévios, desde os alunos que acreditavam que ecossistema fosse o eco até aqueles que o explicaram como sendo o tratamento de água. As entrevistas individuais constituíram-se em momentos importantes para que os alunos pudessem expressar o seu pensamento, mas, ao contrário do que se pensa, entrevistar crianças não é uma tarefa fácil. Pôde-se perceber que, em alguns momentos, a indução das respostas foi inevitável. De uma maneira geral, cada um deles explicou o desenho e o texto elaborado de acordo com a lógica coerente do seu pensamento, a partir dos conhecimentos adquiridos pela experiência de vida.

Sendo assim, as atividades subsequentes também permitiram identificar as noções de seres vivos e não vivos, conceitos importantes para a apreensão do conceito de ecossistema. A análise desses conceitos evidenciou, por exemplo, que muitas crianças ainda usam o movimento e o crescimento como atributos principais para definir os seres vivos.

No primeiro período de interação, caracterizado como o primeiro contato dos alunos com a entrevistadora, desenvolveu-se atividades com o intuito de identificar as noções que os alunos tinham sobre os seres vivos e não vivos. Com base nos dados gerados nessas primeiras atividades, infere-se que o conceito de ser não vivo 
apresentado pelos alunos pode dificultar a compreensão do conceito de ecossistema. Isso se deve ao fato de os alunos relacionarem os seres não vivos com tudo aquilo que não tem vida, centrando em sua grande maioria, em objetos produzidos pelos seres humanos em detrimento dos elementos do nosso ambiente natural, como o ar, a água, sol e temperatura. No entanto, esses elementos são essenciais para a manutenção da vida nos ecossistemas, sejam eles aquáticos, sejam eles terrestres.

Outra observação que pode ser feita é que os conceitos dos alunos sobre ser vivo e não vivo não foram estabelecidos no estudo de Ciências em anos anteriores, o que demonstra a necessidade de eles serem trabalhados e retomados sempre que o professor julgar necessário para, no caso, apreender o conceito de ecossistema. Alguns alunos citaram as plantas e os insetos (animais invertebrados) como sendo seres não vivos. Neste último exemplo, percebe-se a questão cultural apreendida por alguns alunos, que desconsideram os insetos como seres vivos e, quando foi solicitado a eles que escolhessem um ser vivo, optaram por animais vertebrados, mamíferos de grande porte, em sua maioria, como os felinos (onças, leões, tigres). Este fato foi observado na atividade Entrevista sobre os seres vivos, na qual apenas o aluno A8M10 escolheu um caracol (animal invertebrado) em vez de um felino de grande porte.

Quanto ao número de atividades, ao total foram desenvolvidas quinze, desde o início do período de interação até o desenvolvimento das atividades realizadas após a exibição do desenho animado. Além das atividades propostas ou das situações de ensino que foram desenvolvidas de acordo com o delineamento da metodologia, julgou-se necessária a elaboração de outras atividades, como, por exemplo, o jogo da teia alimentar, que teve o intuito de os alunos compreenderem a interdependência entre os seres vivos.

A partir dos resultados gerados, constatou-se, ao contrário do que se pensa, que o uso de diferentes atividades é necessário para o desenvolvimento do complexo processo de formação de conceito realizado pelos alunos e mediado pela entrevistadora, que assumiu a turma como professora. Neste sentido, a apresentação oral não garante a aprendizagem de conceitos, pois esse processo não é linear.

O estabelecimento de diferentes níveis de formulação dos conceitos envolvidos possibilita as generalizações cada vez mais elaboradas até atingir, ou não, a conceptualização. Por isso, Vigotski defendia que o conceito não pode ser assimilado de forma pronta, pois ocorre um processo complexo para a sua formação que se desenvolve somente na adolescência. 
O processo de formação de conceitos pressupõe, como parte fundamental, o domínio do fluxo dos próprios processos psicológicos através do uso funcional da palavra ou do signo. É somente na adolescência que se desenvolve esse domínio dos próprios processos de comportamento com o emprego de meios auxiliares (VIGOTSKI, 2009, p. 172).

Nessa perspectiva, o processo de formação de conceitos caracterizado como uma forma superior de pensamento não pode ser explicada somente pela acumulação de vínculos associativos como supunha a psicologia tradicional, mas por via funcional, principalmente por meio da linguagem, cujo emprego funcional constitui o "meio racionalmente utilizado" (Idem, p. 174).

Os alunos que aparentemente tiveram o primeiro contato com a palavra ecossistema, a exemplo do aluno A8M10, que no início acreditava ter o significado de eco (referente a som), ao final das atividades, conseguiu identificar um dos atributos do conceito: a interdependência entre os seres vivos. A análise das atividades realizadas pelo aluno A8M10 nos permite inferir que houve avanço do significado da palavra, que passou de uma noção vaga, nesse caso sem sentido, para a identificação de um dos atributos do conceito de ecossistema. Sendo assim, foi possível identificar os três tipos de pensamento a partir dos dados gerados: o pensamento sincrético (a imagem formada a partir da percepção imediata), o pensamento por complexos (as primeiras generalizações com base em atributos objetivos) e o pensamento conceitual (a abstração de atributos do conceito). De maneira geral, os alunos não atingiram a conceptualização, mas identificaram um dos atributos caracterizado como o subtipo conceitos potenciais referente ao pensamento conceitual, a interdependência entre os seres vivos.

Quanto ao conceito de ecossistema apresentado na narrativa do desenho animado como o "convívio em harmonia de todas as vidas sobre o planeta, uma dependendo e influindo sobre a outra é o que chamamos de ecossistema" está em consonância com o conceito científico mais aceito, embora seja criticado por muitos autores por não incluir as ações antrópicas, ou seja, as interferências humanas, não podendo considerar que o convívio seja harmonioso. Atualmente, os sistemas ecológicos existentes no planeta sofrem a influência como consequência de desequilíbrios ambientais provocados pelas ações humanas.

Em relação à metodologia empregada, inicialmente foi realizado um estudo prévio, passo importante no desenvolvimento deste projeto, pois permitiu a redefinição do problema de pesquisa e o reajuste do procedimento metodológico. Além disso, entrevistar crianças, conforme comentado anteriormente, não é uma tarefa fácil e esse 
exercício prévio permitiu que eu fizesse uma avaliação da forma como foi conduzida a entrevista no estudo inicial para não cometer os mesmos erros.

Nas primeiras atividades da pré-exibição, referentes à identificação de seres vivos e não vivos, os alunos tiveram dificuldades principalmente na identificação das imagens de seres vivos com as quais nunca tiveram contato, seja por meio real, impresso ou virtual, como, por exemplo: a anêmona, a esponja e o tuiuiú.

Outro aspecto sobre as imagens fixas apresentadas foi a escala referente ao tamanho real dos seres vivos das figuras disponibilizadas. $\mathrm{Na}$ atividade sobre a elaboração da cadeia alimentar, os alunos tiveram dúvidas quanto aos seres vivos que se alimentavam de outros, por exemplo, em uma cadeia elaborada por um aluno, foi possível verificar que inicialmente ele colocou o lambari comendo o piau, embora ocorra justamente o oposto no meio ambiente.

A mesma dúvida foi recorrente na atividade sobre a elaboração das relações ecológicas alimentares do Cerrado. Para abordar os seres vivos em sala de aula, considera-se importante a utilização de diferentes recursos ou materiais, como exemplares taxidermizados ou conservados em laboratórios ou em salas de Ciências, imagens fixas, como as figuras utilizadas ou as imagens em movimento, como os desenhos animados ou filmes, em função da biodiversidade existente.

O jogo da teia alimentar foi outra atividade considerada importante em relação ao desenvolvimento do tema ecossistema, no qual os alunos perceberam a interdependência entre os seres vivos quando se discutiu como ficaria a teia alimentar caso um dos seres vivos fosse extinto ou retirado de seu ambiente natural. Este fato pode ter ocorrido em função do uso do fio de barbante que os alunos seguravam e, quando questionamos o que aconteceria se retirássemos o ser vivo, alguns foram solicitados a soltar o fio e, assim, a rede formada se desfazia. Ao término da brincadeira, os alunos concluíram que havíamos elaborado várias cadeias, formando uma teia alimentar e, ainda, demonstraram compreender a interdependência entre os seres vivos.

Na primeira sessão, o desenho animado começa com a personagem Prof. Lecré, que apresenta um globo terrestre para mostrar como o nosso planeta é fantástico. As imagens em preto e branco são utilizadas como recurso e o que se pretende destacar aparecem em colorido. No momento em que o professor Lecré apresenta o conceito de ecossistema, aparecem em destaque no globo terrestre carros em movimento e pássaros voando e, logo depois, o professor faz uso de analogia para comparar o castelo de cartas com o ecossistema, "se uma não resolver colaborar, o sistema balança até que 
desmorona". Ressalta-se que a escolha do desenho animado Meu corpo, meu mundo justifica-se por apresentar o conceito de ecossistema.

Posteriormente à apresentação do conceito, o Prof. Lecré questiona sobre como nós, seres humanos, temos colaborado com o ecossistema. Para tanto, são evidenciadas as atitudes cotidianas da família Tal, que interferem no equilíbrio do ecossistema, como, por exemplo, o consumo de alimentos (rede fast food ou alimentos industrializados) e de energia elétrica.

Outra interferência no ecossistema destacada pelo Prof. Lecré refere-se ao aquecimento global. Em uma das cenas, o professor abre a janela e o sol fica piscando reforçando a relação entre o aquecimento e este último, deixando de lado os outros fatores responsáveis pelo aquecimento global. Portanto, esse tipo de conhecimento, deve ser analisado em sala de aula com os alunos. Além do conceito de aquecimento global, identificaram-se outros equívocos referentes aos conceitos de gás natural, monóxido de carbono, gás carbônico e leptospirose.

Nas outras sessões, nas quais haviam sido previstos os momentos de pausa, os alunos tiveram a oportunidade de refletir melhor sobre as cenas diante das atividades propostas e interagir com os colegas para discutir as questões tanto apresentadas pelo Prof. Lecré quanto as que foram elaboradas como complementares, e assim expressaram suas opiniões sobre os temas abordados no desenho animado.

As cenas e os temas foram trabalhados minuciosamente em cinco das quinze atividades realizadas durante o estudo, incluindo as do período de observação e de interação. Acredita-se que os momentos de pausa e as interações dialógicas que ocorreram contribuíram para confrontar os conceitos cotidianos dos alunos com os conceitos científicos, permitindo um avanço na direção da formação de conceito, fato que não ocorreu no estudo exploratório.

Quanto ao uso do desenho animado como recurso pedagógico, cabe ao professor planejar e avaliar o uso dessa ferramenta em sala de aula. É importante que o docente analise previamente a narrativa do desenho animado e verifique as possibilidades de uso em sala de aula. O planejamento é de fundamental importância para que o desenho animado não se torne somente um elemento de entretenimento e, sim, que ele faça parte da prática educativa dos professores. Vale ressaltar que o acervo da Videoteca ${ }^{123}$ da

\footnotetext{
123 De acordo com um breve levantamento realizado pela entrevistadora durante esta pesquisa, os professores ainda exploram pouco esse gênero. Apesar de as escolas possuírem salas específicas (salas de vídeo) ou recursos audiovisuais (data show, DVD, televisão) como, por exemplo, o computador interativo, no qual foi disponibilizado para a exibição do desenho animado na escola em que ocorreu a pesquisa.
} 
SEE-DF disponibiliza um número significativo de desenhos animados (ou animações) na área de Ciências Naturais (cinquenta e cinco séries), principalmente para a Educação Infantil e para os Anos Iniciais do Ensino Fundamental da Educação Básica. Além disso, existem também animações e desenhos animados disponibilizados na internet que podem ser utilizados como recurso.

O desenho animado como recurso pedagógico pode ser utilizado como uma ferramenta de ensino-aprendizagem de conceitos, por possibilitar a apresentação do conceito na narrativa, a distinção dos atributos do conceito em questão e a abordagem de temas de uma forma diferente em função das seguintes características: a linguagem própria, a narrativa, as imagens em movimento, a curta duração, adequada ao tempo de aula, e por fazer parte do cotidiano dos alunos. O uso dessa ferramenta deve ser incentivado na sala de aula, pois faz parte do universo infantil, além de contribuir para o desenvolvimento da criticidade e do processo de construção de argumentos.

Neste estudo, a mediação pedagógica foi realizada pela entrevistadora que assumiu o papel de professora nas atividades desenvolvidas. A princípio, acreditava-se que o fato de o aluno assistir a um desenho animado era suficiente para que ele aprendesse um conceito. Entretanto, o aporte teórico e os resultados gerados na primeira etapa da metodologia, o estudo prévio, demonstraram que o desenho por si só não garante a formação de conceitos científicos, sendo necessária a mediação do professor, no caso, a entrevistadora.

$\mathrm{Na}$ primeira etapa da metodologia da tese, a mediação pedagógica não foi contemplada no estudo prévio com momentos de discussão sobre o tema aquecimento global. A redefinição da metodologia buscou inserir esses momentos nas atividades para possibilitar à entrevistadora atuar na zona de desenvolvimento iminente dos alunos, ou seja, colaborar com o aluno na capacidade de realizar ou de desenvolver uma atividade.

Nas entrevistas individuais, ficou evidenciado que a interposição realizada pela entrevistadora com questionamentos sobre o conhecimento empírico dos alunos permitiu que eles refletissem sobre suas concepções. Além disso, a entrevista criou espaços para que ocorressem essas interações dialógicas, o que possibilitou esclarecer as dúvidas apresentadas pelos alunos. A título de exemplo, o aluno A8M10 questiona, na última entrevista, quanto à cena do desenho animado Meu corpo, meu mundo:

A8M10: Eu não sei por que o Prof. Lecré falou que boi vira molho. E: Por causa do molho a bolonhesa.

A8M10: Ah! (Sinalizando com a cabeça que havia compreendido) 
E: Da carne moída, então por isso que precisa do molho de tomate e dos boizinhos que ele falou.

Na cena acima referida, o Prof. Lecré relata que tudo que precisamos para sobreviver vem do nosso planeta e, como exemplo, ele cita a macarronada. Para a preparação da macarronada, o professor apresenta uma fazendinha que tem os boizinhos, os ovos, os tomates e o trigo. Neste caso, houve a necessidade de esclarecer o sentido expresso pela imagem dos boizinhos, realizada por meio da mediação.

Outro aspecto a ser considerado foi o envolvimento dos alunos nas discussões que ocorreram durante as atividades, o que reforçou as interações entre os alunos. Esses momentos foram relevantes para que a entrevistadora pudesse compreender o que os alunos pensavam sobre o tema ecossistema e os conceitos a ele relacionados, confrontando os conhecimentos deles para ajudá-los na reelaboração conceitual, caso necessário.

E ainda, os alunos querem falar e serem ouvidos e, muitas vezes, nas situações escolares, eles são podados. Como saber o que pensam e como pensam sobre determinados assuntos se, no espaço da sala de aula, não são criados esses momentos para que eles possam se expressar? Nesse caso, o fato de o professor observar o comportamento deles diante das situações de aprendizagem colocadas contribuiria para compreender melhor como estão pensando e para poder colaborar para superar essas dificuldades, caso elas existam. Nos Anos Iniciais do Ensino Fundamental, posso dizer que esse fato é possível em função de o professor ter somente uma turma, com uma média de trinta a trinta e cinco alunos. Quanto aos Anos Finais do Ensino Fundamental, se torna mais difícil tal observação, porque o professor de área específica tem em média de sete a oito turmas, com quarenta a quarenta e cinco alunos cada. Embora seja mais difícil, não é uma tarefa impossível.

No entanto, empenho não cabe somente ao professor, os alunos também devem estar dispostos a aprender. Por isso, Vigotski defendia que o aluno se educa e não o professor. Em contrapartida, é o professor que elabora as situações que motivam os alunos à aprendizagem.

A mudança de rotina torna-se uma motivação para a aprendizagem. No estudo desenvolvido, percebeu-se, por exemplo, que o simples fato de mudar a disposição das carteiras (em formato de meia lua, para a primeira exibição do desenho animado (Sessão 1) permitiu maior interação entre os alunos.

A esse respeito, a importância da mediação pedagógica deve-se ao fato de o professor criar as condições para que ocorra o processo de aprendizagem do aluno, o 
seu desenvolvimento intelectual. Planejar a execução das atividades propostas e possibilitar as interações dialógicas para compreender o pensamento dos alunos e atuar na zona de desenvolvimento iminente.

No entanto, no desenvolvimento desse estudo foi possível identificar algumas limitações como: os erros conceituais que não foram discutidos com os alunos em função do foco no conceito de ecossistema, o foco somente na cadeia alimentar para estabelecer as relações ecológicas e a interdependência entre os seres vivos, sem ampliar para os seres não vivos.

Destacam-se como contribuições desse estudo a pesquisa empírica sobre a formação de conceito, o potencial pedagógico do desenho animado para fins educativos, a complexidade do processo de formação de conceito que demandam atividades ou sequências didáticas para que ocorra a distinção de atributos e a apreensão do conceito e, posteriormente, a aplicabilidade em outras situações. Além disso, o estudo permitiu demonstrar que a mediação pedagógica realizada pelo professor é importante para a negociação de sentidos e significados discutidos durante o processo de ensinoaprendizagem de conceitos no desenvolvimento das atividades.

As trajetórias continuam animadas porque seria impossível pontuar uma conclusão fechada ou determinada em função dos dados gerados no estudo, o que instiga a buscar outras formas de compreender o processo de formação de conceito no desenvolvimento intelectual da criança com o uso de outros recursos pedagógicos mediados pelo professor.

Diante das questões levantadas sobre a formação de conceito de ecossistema, com base nos resultados gerados, o presente estudo considera o uso do desenho animado como um recurso pedagógico pertinente no ensino-aprendizagem de conceitos em função da linguagem adequada, do conteúdo da narrativa que possibilita a discussão de diferentes conceitos e temas, desde que seja mediado pelo professor, e, ainda, integrar o cotidiano dos alunos com o uso de novas ferramentas disponíveis em diferentes suportes tecnológicos no ambiente escolar. 


\section{REFERÊNCIAS BIBLIOGRÁFICAS}

AB'SABER, A. N. Relevância e significado da educação científica para o Brasil. In: WHERTEIN, J.; CUNHA, C. (org.) Ensino de Ciências e Desenvolvimento: o que pensam os cientistas. Brasília: UNESCO, Instituto Sangari, 2009.

ANDRADA, L. P. D. O professor na psicologia histórico-cultural: da relação à mediação pedagógica. Dissertação de Mestrado, Universidade de Brasília - Faculdade de Educação : [s.n.], 2006.

APARICI MARINO, R.; GARCÍA MATILLA, A. Lectura de imágenes. Madrid: Ediciones de La Torre, 1998.

AUSUBEL, D. P.; NOVAK, J. D.; HANESIAN, H. Psicologia Educacional. Rio de Janeiro: Interamericana, 1980.

BARBOSA JÚNIOR, A. L. Arte da Animação:técnica e estética através da história. São Paulo: Senac, 2005.

BORTOLETTO, M. Ideologias animadas: a criança e o desenho animado.Dissertação de Mestrado, Programa de Pós-Graduação em Educação, Universidade Estadual de Campinas (UNICAMP-SP), 114 p., 2008.

BRASIL. Ministério da Educação. Secretaria de Educação Básica. Parâmetros Curriculares Nacionais. Brasília-DF, 1998.

BROWNLOW, S.; DURHAM, S. Sex differences in the use of Science and Technology in children's cartoon. Journal of Science Education and Technology, v. 6, n. 2, 1997. 103-110.

BRUZZO, C. As histórias infantis de Disney. BRUZZO, C. (org.) In: Lições com cinema: animação. São Paulo: FDE, 1996.

CALADO, I. A utilização educativa das imagens. Portugal: Porto , 1994.

CARNEIRO, M. H. S. As imagens no livro didático. Atas do I Encontro Nacional de Pesquisa em Ensino de Ciências. São Paulo, Águas de Lindóia: UFSC. 1997. p. 366373.

CARVALHAL, F. C. A. Instituto Nacional de Cinema Educativo: da história escrita à história contada - um novo olhar, 2009. Disponível em: <http://www.mnemocine.com.br>. Acessado em: 15 out. 2012.

COELHO, R. A Arte da Animação. Belo Horizonte: Formato, 2000.

DIAS, B. C. Em busca de uma práxis em Educação Ambiental crítica: contribuições de alguns pesquisadores do Brasil. Dissertação de Mestrado, Instituto Federal de Educação, Ciência e Tecnologia do Rio de Janeiro, Rio de Janeiro - RJ, 2013. 
DISTRITO FEDERAL. Secretaria de Estado de Educação. Currículo em Movimento da Educação Básica:Pressupostos teóricos. Brasília: [s.n.], 2014a.

DISTRITO FEDERAL. Secretaria de Estado de Educação. Currículo em Movimento da Educação Básica:Ensino Fundamental - Anos Iniciais.Brasília - DF: [s.n.], 2014b.

DUARTE, N. Educação escolar, teoria do cotidiano e a escola de Vigotski. Campinas: Autores Associados, 2001.

DUARTE, R. Cinema \& Educação. Belo Horizonte: Autêntica, 2002.

FERREIRA, M. S. Buscando caminhos: uma metodologia para o ensino-aprendizagem de conceitos. Brasília : LiberLivro, 2009.

FONTANA, R. A. C. Mediação pedagógica na sala de aula. Campinas: Autores Associados. Coleção Educação Contemporânea, 1996.

GARCIA, D. G. A política editorial do INC. Filme Cultura, v. 5, jul./ago. 1967. 1-7.

GARCÍA, E. A natureza do conhecimento escolar: transição do cotidiano para o científico ou do simples para o complexo? In: RODRIGO, M. J.; ARNAY, J. Conhecimento cotidiano, escolar e científico:representação e mudança. São Paulo: Ática, 1998. p. 238.

GARCIA, J. F. M. A. A Produção de sentidos no contexto de uma aula de ciências sobre adaptação biológica mediada por um desenho de animação.Dissertação de Mestrado, Faculdade de Educação/UFMG, 2009.

GIORDAN, A.; DE VECCHI, G. As origens do saber:das concepções dos aprendentes aos conceitos científicos. Porto Alegre: Artes Médicas, 1996.

HALAS, J.; MANVELL, R. The thecnique of film animation. New York: Hasting House, 1971.

HILTY, G. Objeto, sonho e imaginação na animação. In: (ORG.), B. C. Movie-se: no tempo da animação. [S.l.]: Barbican Centre, 2012 Disponível em: $<$ http://culturalbancodobrasil.com.br/portal/wpcontent/uploads/2013/05/MovieSe.pdf >.Acesso em: 20 dez. 2014.

HOBAN, G.; NIELSEN, W. Learning Science through Creating a 'Slowmation': A case study of preservice primary teachers. International Journal of Science Education, vol. 35 (1), 2013. 119-146.

HOUAISS, A.; VILLAR, M. S.; FRANCO, M. M. Dicionário Houaiss da língua portuguesa. Rio de Janeiro: Objetiva, 2009.

IVIC, I. Lev Semionovich Vygotsky. Coleção Educadores (MEC). Recife: Fundação Joaquim Nabuco/Massunanga, 2010. 140 p.

KINDEL, E. A. A Natureza no Desenho Animado Ensinando sobre Homem, Mulher, Raça, Etnia e outras coisas mais. Tese de Doutorado, Faculdade de Educação da Universidade Federal do Rio Grande do Sul, Porto Alegre - RS. 195 p., 2003. 
KOSTIUK, G. S. Alguns aspectos da relação recíproca entre educação e desenvolvimento da personalidade. In: LURIA, A. R.; LEONTIEV, A.; VIGOTSKY, L. S. Psicologia e Pedagogia I. 2. ed. Lisboa: Editorial Estampa , 1991.

LEITÃO, A. S. P. Desenhos animados televisivos, Ética e Educação Física nos Anos Iniciais no Ensino Fundamental: diálogos possíveis. Dissertação de Mestrado, Universidade Estadual Paulista (UNESP), Presidente Prudente - SP. 105 p., 2011.

LEONTIEV, A. N. Uma contribuição à teoria do desenvolvimento da psique infantil. In: VIGOTSKII, L. S.; LURIA, A. R.; LEONTIEV, A. N. Linguagem, desenvolvimento e aprendizagem. 5. ed. São Paulo: Ícone: Editora da Universidade de São Paulo, 1994.

LURIA, A. R. Vigotskii. In: VYGOTSKII, L. S.; LURIA, A. R.; LEONTIEV, A. N. Linguagem, desenvolvimento e aprendizagem. São Paulo: Ícone, 1994a. p. 228.

LURIA, A. R. Diferenças culturais de pensamento. In: VYGOTSKII, L. S.; LURIA, A. R.; LEONTIEV, A. N. Linguagem, desenvolvimento e aprendizagem. São Paulo: Ícone, 1994b.

LURIA, A. R. Curso de Psicologia Geral.v. IV- Linguagem e Pensamento. Rio de Janeiro: Civilização Brasileira, 1994c.

MACIEL, M. L. B.; VENTURELLI, S. Imagem interativa. Brasília: Universidade de Brasília, 2008.

MADSEN, R. Animated film: Concepts, methods, uses. New York: Interland Publication, 1969.

MAREUSE, M. A. G. A Representação Infantil da Violência na Mídia: Uma Perspectiva para Repensar a Educação. Tese de Doutorado, Departamento de Comunicações e Artes, Universidade de São Paulo, São Paulo - SP. 329 p., 2007.

MASSARANI, L (org.). Pequeno cientista amador: a divulgação científica e o público infantil. Rio de Janeiro: Casa da Ciência e Universidade Federal do Rio de Janeiro (UFRJ), 2005.

MEDEIROS, R. F. Bob Esponja: Produções de sentidos sobre infâncias e masculinidades.Dissertação de Mestrado, Programa de Pós-Graduação em Educação, Universidade Federal do Rio Grande do Sul, Porto Alegre- RS. 130 p., 2010.

MEDEIROS, S. O Projeto TV Escola. In: Brasília: SEED/MEC e UniRede, 2002. TV na Escola e os desafios de hoje.

MENDONÇA-FILHO, J.; TOMAZELLO, M. G. C. As imagens de ecossistema em livros didáticos de Ciências e suas implicações para a Educação Ambiental. IV Encontro Nacional de Pesquisa em Educação em Ciências. Bauru-SP: [s.n.]. 2003. Disponível em http://fep.if.usp.br/ profis/arquivos/ivenpec/ Arquivos/Painel/ PNL073.pdf. Acessado em 03/04/2014. 
MESQUITA, N. A. S.; SOARES, M. H. F. B. Visões de Ciência em desenhos animados: uma alternativa para o debate sobre a construção do conhecimento científico em sala de aula. Ciência \& Educação, v. 14, n. 3, São Paulo, 2008. 417-429.

MILLIET, J.; MAGALHÃES, M. Anima Escola:10 anos. Rio de Janeiro: Sol Gráfica, 2011.

MIRANDA, A. R. Os desenhos animados infantis e os valores culturais contemporâneos.Dissertação de Mestrado, Universidade São Marcos - São Paulo, 156 p., 2009.

MITTERMEIER, R. A.; MITTERMEIER, C. G.; MYERS, N.; PATRÍCIO, R. G. Hotspots Earth's Biologically Richest and Most Endangered Terrestrial Ecoregions. Cemex S/A, México, 1999.

MONTEIRO, P. C. O que pensam alunos de $9^{\text {a }}$ Série do Ensino Fundamental sobre Ciência e Cientista nos Desenhos de Jimmy Neutron. Dissertação de Mestrado, Universidade Estadual de Maringá, 140 p, 2011.

MORENO, A. A experiência brasileira no cinema de animação. Rio de Janeiro: Arte Nova, 1978.

MORETTIN, E. V. Cinema Educativo: uma abordagem histórica. Comunicação \& Educação, v. 4, São Paulo, 1995.

NAPOLITANO, M. Como usar o cinema em sala de aula. 2. ed. São Paulo: Contexto, 2005.

NATADZE, G. A. A aprendizagem de conceitos científicos na escola. In: LURIA, A. R.; LEONTIEV, A.; VYGOTSKY, L. S. Psicologia e Pedagogia II: Investigações experimentais sobre problemas didáticos específicos. Lisboa: Estampa, 1991.

NESTERIUK, S. Dramaturgia de séries de animação. I Programa de Fomento à Produção e Teledifusão de Séries de Animação Brasileiras - ANIMATV. 1. ed. São Paulo: [s.n.], 2011.

ODUM, E. P.; BARRET, G. W. Fundamentos de Ecologia. São Paulo: Cengage Learning, 2011.

OLIVEIRA, M. B. A tradição Roschiana. In: OLIVEIRA, M. B.; OLIVEIRA, M. K. Investigações Cognitivas: conceitos, linguagem e cultura. Porto Alegre: Artes Médicas, 1999.

OLIVEIRA, M. K. Três questões sobre o desenvolvimento conceitual. OLIVEIRA, M. B. D.; OLIVEIRA, M. K. D. Investigações Cognitivas: Conceitos, Linguagem e Cultura. Porto Alegre: Artes Médicas , 1999.

OLIVEIRA, M. K. Vygotsky: Aprendizado e desenvolvimento - Um processo sóciohistórico. São Paulo: Scipione: Scipione, 1997. 105 p.

PACHECO, E. D. Televisão, criança, imaginário e educação: dilemas e diálogos. Campinas: Papirus, 1998. 
PERALES-PALACIOS, F. J.; VÍLCHEZ-GONZÁLEZ, J. M. The Teaching of Physics and Cartoons: Can they be interrelated in secondary education? International Journal of Science Education, v. 27, n. 14, 2005. 1647-1670.

PEREIRA, P. G. Animaq: almanaque dos desenhos animados. São Paulo: Matrix, 2010.

PERISIC, Z. Guia prático do Cinema de Animação. São Paulo: Martins Fontes, 1979.

PILIOURAS, P.; SIAKAS, S.; SEROGLOU, F. Pupils produce their own narratives inspired by the History of Science: animation movies concerning the GeocentricHeliocentric debate. Science \& Education, v. 20, 2011. 761-795.

PINTO-COELHO, R. M. Fundamentos em Ecologia. Porto Alegre: ArtMed, 2000.

PONCET, M.-T. O desenho animado. Lisboa: Editorial Estúdios Cor. Diagramas 59, s.d.

PRESTES, Z. R. Quando não é quase a mesma coisa: Análise de traduções de Lev Seminiovitch Vigotski - Repercussões no campo educacional. Tese de Doutorado, Faculdade de Educação, Universidade de Brasília (UnB) - DF, 2010.

QUEIROZ, A. Anima Mundi: Mostra Internacional de Animação: filmes, vídeos, palestras, workshop. Brasília: Centro Cultural Banco do Brasil, 1993.

QUEIROZ, N. Imagem e Pensamento: da atração do olhar à significação do conceito. Dissertação de Mestrado, Faculdade de Educação, Universidade de Brasília (UnB) - DF. 190 p., 2007.

REGO, T. C. Vygotsky: uma perspectiva histórico-cultural da educação. Petrópolis: Vozes, 1995.

RIBEIRO, R. J.; SILVA, S. C. R.; KOSCIANSKI, A. Organizadores prévios para aprendizagem significativa em Física: o formato curta de animação. ENSAIO, v. 14, Belo Horizonte, 2012. 167-183.

RICKLEFS, R. E. A Economia da Natureza. Rio de Janeiro: Guanabara Koogan, 2010.

ROCHA, M. S. P. M. L. Crianças, televisão e animes: intertextos.Tese de Doutorado, Faculdade de Educação, Universidade Estadual de Campinas, Campinas- SP. 212 p. , 2005 .

ROGOFF, B. Observando a atividade sociocultural em três planos: apropriação participatória, participação guiada e aprendizado. In: WERTSCH, J. V.; RÍO, P. D.; ALVAREZ, A. Estudos socioculturais da mente. Porto Alegre: ArtMed, 1998.

SABAT, R. Filmes infantis e a produção performática da heterossexualidade.Tese de Doutorado, Faculdade de Educação da Universidade Federal do Rio Grande do Sul, Porto Alegre - RS. 185 p., 2003.

SACRISTÁN, G. Currículo: uma reflexão sobre a prática. Porto Alegre: Artes Médicas, 2000. 
SAKHAROV, L. Methods for investigating concepts. In: VEER, V. D.; VALSINER, J. The Vygotsky Reader. Oxford (UK) and Cambridge (USA): Blackwell Publishers, 1994.

SANGARI BRASIL. Seres Vivos: livro do professor. São Paulo: Sangrai do Brasil, 2007. (CTC: Ciência e Tecnologia com Criatividade)

SANTOS, J. L. O que é Cultura. São Paulo: Brasiliense (Coleção Primeiro Passos), 2007.

SANTOS, S. O. R. Representações de gênero, transgressão e humor nas figuras infantis dos desenhos animados contemporâneos.Tese de Doutorado, Universidade Federal do Rio Grande do Sul, Porto Alegre - RS. 222 p. , 2010.

SERRANO, J.; VEnÂNCIO-FILHO, F. Cinema e Educação. São Paulo: Melhoramentos, 1930.

SEVERINO, A. J. Metodologia do trabalho científico. 23. ed. São Paulo: Cortez, 2007.

SFORNI, M. S. D. F. Aprendizagem conceitual e organização do ensino: contribuições da Teoria da Atividade. Araraquara: JM Editora, 2004.

SILVA, M. S. M. M. D. Desenho Animado e Educação: Calça quadrada, cabeça redonda? Tese de Doutorado, Universidade Federal de João Pessoa - João Pessoa - PB. 167 p., 2010.

SILVA, S. A. Os animes e o Ensino de Ciências. Dissertação de Mestrado, Mestrado Profissionalizante em Ensino de Ciências - Instituto de Química, Universidade de Brasília, 2011.

SIQUEIRA, D. C. O. O cientista na animação televisiva. Em Questão. Porto Alegre, jan/jun., 2006, 131-140.

STRICKLAND, C.; BOSWELL, J. Arte Comentada:da Pré-história ao Pós-Moderno. Rio de Janeiro: Ediouro, 1999.

TACCA, M. C. V. R. Estratégias Pedagógicas: conceituação e desdobramentos com o foco nas relações professor-aluno. In: TACCA, M. C. V. R. (org.)Aprendizagem e Trabalho Pedagógico. Campinas: Alínea, 2006. Cap. 3.

TELLES, M. Q. et al.Vivências Integradas com o Meio Ambiente. São Paulo: Ed. Sá, 2002.

TOMAZI, A. L. et al. O que é e quem faz Ciência? Imagens sobre a atividade científica divulgadas em filmes de animação infantil. Revista Ensaio, Belo Horizonte, 11 (2), 2009.

TRIVELATO, S. F.; SILVA, R. L. F. Ensino de Ciências. São Paulo: Cengage, 2011. 
TRIVIÑOS, A. N. S. Introdução à pesquisa em Ciências Sociais - a pesquisa qualitativa em educação: o positivismo, a fenomenologia, o marxismo. São Paulo: Atlas, 1987.

TUNES, E. Os conceitos científicos e o desenvolvimento do pensamento verbal. In: Caderno Cedes, n. 35. Implicações pedagógicas do modelo histórico-cultural. Campinas: Papirus, 1995, p. 29-39.

TUNES, E.; TACCA, M. C. V. R.; BARTHOLO JÚNIOR, R. S. O professor e o ato de ensinar. Cadernos de pesquisa, v. 35, n. 126. São Paulo, set/dez 2005. 689-698.

TUNES, E.; TACCA, M. C. V. R.; MARTÍNEZ, A. M. Uma crítica às teorias clássicas e à sua expressão no campo educativo. Linhas Críticas, Brasília, v.12. n. 22 , jan./jun. 2006. 109-130.

VAN DER VEER, R.; VALSINER, J. Vygotsky: uma síntese. São Paulo: Loyola, 1999. $478 \mathrm{p}$.

VIGOTSKI, L. S. A formação social da mente: o desenvolvimento dos processos psicológicos superiores. São Paulo: Martins Fontes, 1998.

VIGOTSKI, L. S. A construção do pensamento e da linguagem. 2. ed. São Paulo: Martins Fontes, 2009.

VIGOTSKII, L. S. Aprendizagem e desenvolvimento intelectual na idade escolar. In: VYGOTSKII, L. S.; LURIA, A. R.; LEONTIEV, A. N. Linguagem, desenvolvimento e aprendizagem. São Paulo: Ícone, 1994. p. 228.

VÍLCHEZ-GONZÁLEZ, J. M. Fisica y dibujos animados. Una estrategia de alfabetización científica y audiovisual em La Educación Secundária. Tese de Doutorado, Departamento de Didáctica de Las Ciencias Experimentales, Universidade de Granada - Espanha, 388 p., 2004.

VÍLCHEZ-GONZÁLEZ, J. M.; PERALES-PALACIOS, F. J. Enseñando Física com Dibujos Animados. Enseñanza de Las Ciências, número extra VII Congresso, 2005.

VYGOTSKY, L. S. Obras Escogidas:Historia del desarrollo de las funciones psíquicas superiores.Tomo III. Madri: Visor, 1997.

VYGOTSKY, L. S.; LURIA, A. R. A história do comportamento:o macaco, o primitivo e a criança. Porto Alegre: Artes Médicas , 1996.

WENZEL, M. C. R. O desenho animado:o discurso-imagem. Dissertação de Mestrado, Faculdade de Educação. Universidade Estadual de Campinas. Campinas-SP. 152 p., 2002.

WERTSCH, J. V.; RÍO, P. D.; ALVAREZ, A. Estudos socioculturais: história, ação e mediação. In: WERTSCH, J. V.; RÍO, P. D.; ALVAREZ, A. Estudos socioculturais da mente. Porto Alegre: ArtMed, 1998. 
XAVIER, J. F. P. Uso do desenho animado ambiental como estratégia metodológica para Educação Ambiental. Dissertação de Mestrado, Programa de Mestrado Acadêmico em Educação - Universidade do Vale Itajaí (UNIVALI-SC), 135p., 2008. 


\section{APÊNDICE A}

\section{Transcrição do desenho animado Meu Corpo, Meu Mundo}

Prof. Lecré: Lindo, não? Nosso planeta é mesmo fantástico! Uma gota de vida boiando no universo em perfeita harmonia!

Hum, mas será que é tão simples assim? Ouohhh! Ouhoh, uhhh! Uh, hahaha, uh!

Pois é, o planeta Terra também precisa de cuidados! Você já pensou que tudo que precisa para viver vem do planeta? Observe, essa macarronada...oh, eih, quero dizer, essa fazendinha aqui! Com o trigo e os ovos a gente faz a massa! Os tomates, pobrezinhos, esses boizinhos vão virar o molho! E aqui está um bom suco de laranja! Então pra gente desfrutar da macarronada, essa fazendinha precisa sobreviver! Precisa do calor do sol, de ar puro, de água da chuva! Mas de onde será que vem o gás que faz o fogo que nasce do nosso fogão?

Olha ele aí, o gás natural! Que é retirado lá do fundo da terra, e é ali perto que às vezes encontramos também o famoso petróleo, que gera vários tipos de materiais como o plástico e de combustíveis como a gasolina!

O convívio em harmonia de todas as vidas sobre o planeta, uma dependendo da outra é o que chamamos de ecossistema! É como esse castelo, onde cada carta depende uma da outra para manter o equilíbrio e se uma resolver não colaborar, o sistema balança, balança, até que desmorona! E como é que nós, seres humanos, temos colaborado com o ecossistema do nosso planeta?

Vejamos aqui, essa família comum! Psiiiuuu, ainda estão dormindo!

Áudio: som de ronco

Áudio: som de despertador tocando

Prof. Lecré: Agora sim, hahaha, vai começar mais um doce dia tal da família Tal! O senhor Fulano de Tal, muito asseado, acorda e vai logo tomar seu banho, quente, naturalmente! Antes vai fazer a barba, ham, ah, mas se antes vai fazer a barba porque ligou o chuveiro, afinal?

E essa é a digníssima Sicrana de Tal! Sempre na correria, Dona Sicrana de Tal passando seu uniforme na última hora! Eih, a torrada subiu! E a conta de energia, rororó (ou hohoho)!

E não é que o consumo de energia interfere no equilíbrio do ecossistema! Como? Oras, vejam o que acontece nos arredores de uma usina hidroelétrica, por exemplo! Então, quanto mais aparelho a gente liga, mais energia precisa ser produzida, mais 
usinas construídas, mais áreas devastadas e gases emitidos aumentando mais e mais a temperatura da Terra!

Ah, ah, ufa, que calor, ahm! Assim, nossos aparelhos elétricos são também uma contribuição para o tão afamado, aquecimento global! E esse o aquecimento global pode ser o responsável pelas mais diversas maluquices climáticas!

Áreas férteis podem passar por longas secas e até se tornar desérticas! Chuvas fortes e trovoadas podem surgir de repente e lá vem enchente! Doenças tropicais como a malária e a dengue que precisam de calor e umidade para se desenvolver podem permanecer por períodos bem mais longos, se espalhar por regiões bem maiores e atingir bem mais gente!

Mas não é só desperdiçando energia que a gente fortalece o aquecimento global! Voltemos à família Tal! Olha, que bonitinho, Beltraninho já vai para a escola e vai de Van porque mamãe Sicrana não tem tempo de levá-lo, é justo!

Fulano e Sicrana gostam de ir para o trabalho cada um no seu carro pra chegar até a porta, vocês sabem! E lá vão eles! Mas ela ficou logo ali?

Ixi, ah lá, engarrafamento! É justamente o que ocorre quando todas as pessoas querem usar cada um o seu próprio carro! E a fumaça, ahm? O médico disse que os pulmões do seu Fulano vão de mal a pior, ele está preocupado com isso! Mas preocupante mesmo é a saúde do seu filhinho, Beltraninho, tão pequenininho e já sofrendo com a bronquite!

Veja a fumaça dos automóveis vai para a atmosfera contendo monóxido de carbono que faz um mal danado para a nossa saúde e o gás carbônico que é um dos grandes vilões do aquecimento global! Muitas das atividades do homem e até da natureza produzem gás carbônico, mas poucas podem consumi-lo! A fotossíntese das árvores é uma delas, mas é preciso muita árvore para consumir tanto gás carbônico!

A família Tal bem que gostaria de fazer alguma coisa, mas como poderiam plantar uma árvore? Pois bem, olha a nossa velha conhecida no escritório, parece um dia atribulado! E aí, ficou bom? Nãooo, e erraram de novo e de novo e de novo, oh, ró! A gente não está cansado de saber que é da árvore que se faz o papel? Então, quanto mais papel a gente usa, não é mais árvore que a gente corta e menos gás carbônico que ela consome? Além de árvores, você sabe que para fabricar papel, se gasta uma enorme quantidade de água limpa? E tanta gente precisa de água limpa, não? No Brasil mesmo, tanta criança doente por causa de ingestão de água não tratada! E tanta gente desperdiça o que tem, é triste! 
Opaaa, olha quem nós encontramos aqui! Senhor Fulano é engenheiro de uma grande construção! Parece que eles vão cobrir esse jardim e fazer um pátio! Em outras palavras, vão impermeabilizar esse pequeno pedaço de terra, que até então mesmo dentro da cidade conseguia respirar e beber água direto da chuva! Daqui pra frente toda a água que penetrava nessa área espalhava-se naturalmente pela terra vai escorrer sobre o cimento, procurar um bueiro e correr direto para um dos poluídos rios da cidade, ou seja, é mais um pouquinho de água suja, sem falar nas enchentes que virão!

Áudio: som de sirene

\section{Prof. Lecré:}

Ehreh, hora do almoço, rorô! E porque não vai à pé? Sabia que um pouquinho de caminhada é sempre bom para a sua postura, para a sua circulação, pro seu coração? É claro que sabia! Mas então, porque tá indo de carro? E lá se vai mais gás carbônico!

Viu só, olha a tosse! A coluna, hahahãm! Se tá abatidinho, hein? O bom aqui é que a comida chega rapidinho, não é? Hehehe! Agora rapidinha mesmo é a vida útil dessa caixinha, hein? Já pensou? Derruba a árvore, suja a água, corta, dobra, pinta, embala e vai viajar! Primeiro, num caminhãozão, depois em um caminhãozinho e chega à lanchonete! Só aqui começa a vida útil da nossa gloriosa caixinha! O funcionário coloca o sanduíche na caixinha, a caixinha na prateleira, seu Fulano pega a caixinha, leva a caixinha pra mesa, tira o sanduíche e joga a caixinha no lixo! Aproximadamente, cinco minutos depois que ganhou o primeiro e único sanduíche de sua nobre carreira de caixinha de lanchonete, e agora, a nossa caixinha de papel misturada à outros resíduos plásticos, metálicos, orgânicos e até alguns resíduos tóxicos vai parar em aterros sanitários lotados, ou mesmo, dependendo da administração da sua cidade, em lixões a céu aberto onde proliferam animais e bactérias que transmitem diversas doenças para a população dos arredores, além de liberar mais gases para o meio ambiente!

E, já como não bastasse, esse lixo todo misturado produz um líquido altamente tóxico, que se penetrar no solo pode contaminar inclusive os lençóis freáticos da região! Para quem não sabe, os lençóis freáticos são canais de água subterrâneos, essa água espalha-se por uma grande extensão de terra podendo servir para o consumo direto ou para aguar plantações! Resultado: o líquido tóxico dos enormes amontoados de lixo que geramos acaba contaminando alimento e água que nós mesmos poderemos consumir!

Beltraninho: Hahaha!

Prof. Lecré: Opaaa, esse aí a gente já conhece, o mosquito da dengue, lembra? Que gosta de calor e água parada! Pois é, Sicrana de Tal acaba de ficar doente! Bonito, né! Além de enfeiar as ruas, o seu copo ajuda a entupir os bueiros prejudicando o 
escoamento da água da chuva e influenciando diretamente as enchentes nas sua cidade! As águas sujas das enchentes espalham doenças gravíssimas como a leptospirose, uma doença que pode até matar! Mas não pensemos no pior, também só faltava essa! Depois desse dia de cão, Fulano de Tal está acabado! Ixiii, Sicrana também está péssima com uma dor de cabeça! E o Beltraninho, tadinho, crise de bronquite, oh que dó! Se vocês pudessem acordar de novo, aham? Vejamos o que eu posso fazer por vocês! Tipo: super-homem, mas vocês vão ter que colaborar!

Áudio: som de "rebobinamento"

Áudio: Despertador tocando

Prof. Lecré: Só ligue o chuveiro na hora de entrar no banho, Fulano, meu caro! E você, Sicrana, se passar todas as roupas de uma só vez vai economizar bastante energia na conta e no planeta! Evite usar excessivamente aparelhos elétricos, prefira alimentos frescos, por exemplo! Podendo, utilize o transporte público, se realmente não der, não é ótimo ficar mais um pouquinho com a família! Dê carona, inclusive para os vizinhos, o trânsito da cidade e os seus pulmões vão agradecer! Não imprima papéis desnecessariamente, sempre que puder, leia os documentos no próprio computador! Os documentos impressos que não te interessam mais, geralmente, têm um lado branco que você pode reutilizá-lo como rascunho! E quando não tiver mais uso mande para a reciclagem sem enrolar! Ah, sim, esse prédio vai ficar bem mais bonito com um belo jardim!

Áudio: som de sirene

Prof. Lecré: Se for pertinho, vá andando Fulano! Nada como o velho e bom feijão com arroz, eh! Vai super bem e não vem com aquele monte de embalagem! Recuse sempre o que for desnecessário, nunca suje as ruas de sua cidade, logo você encontra uma lixeira! Ora, troque os descartáveis por utensílios mais duráveis como os copos de vidro! Hehe, reunião familiar! Agora sim, um fim de tarde feliz, não é? Foi difícil?

Família Tal: sinalizam não com a cabeça

Prof. Lecré: Pois é, é só refletir um pouco antes de tomar cada atitude ponderando sempre as decisões que no final fica melhor para todo mundo

Família Tal: sinalizam sim com a cabeça

Prof. Lecré: Querem saber o que vai acontecer depois?

Família Tal: sinalizam sim com a cabeça 
Prof. Lecré: O que será que eu vejo aqui? Vou só dar uma dica, tá bom? Sim, estou vendo! O jovem Beltraninho está andando de bicicleta! Parece que está indo pra escola? Haha, e não está sozinho, não!

Ai, ai! 


\section{APÊNDICE B}

\section{Análise Crítica do desenho animado Meu corpo, meu mundo}

A animação Meu corpo, meu mundo, produzida pela cineasta Érica Martins Valle, foi um dos projetos vencedores do primeiro concurso lançado pela FIOCRUZ Vídeo, realizado em 2008, com o objetivo de financiar as produções audiovisuais sobre o tema saúde. De um total de cento e cinquenta e cinco inscritos, sete projetos de filmes de curta ou média-metragem foram premiados em diferentes gêneros ou modalidades (animação, documentários e ficção). O DVD Anima Saúde é resultante do primeiro concurso lançado pela FIOCRUZ e composto por três animações: Rattus Rattus; Meu corpo, meu mundo e A peleja dos guerreiros Sá\&Úde contra os monstros Dó\&Ença no país dos Tropic\&Ais.

As principais personagens são o Professor Lecré e a Família Tal, representada pelo pai Fulano de Tal, pela mãe Dona Sicrana de Tal e o filho único Beltraninho. Os nomes Fulano, Sicrana e Beltraninho (diminutivo de Beltrano) são expressões do idioma português que fazem referência a uma pessoa qualquer ou desconhecida, compreendida e compartilhada na linguagem popular presente na cultura brasileira.

A história do desenho animado Meи соrpo, meu mundo é narrada pelo Prof. Lecré, que a inicia destacando como o nosso planeta é fantástico (lindo) e emprega como recurso um globo terrestre.

O desenho chama a atenção pelos traços simples e as imagens se apresentam em branco, preto e tons de cinza e o que se pretende destacar é apresentado de forma colorida como, por exemplo, a cor da blusa do senhor Fulano de Tal que é azul, uma referência ao gênero masculino, assim como a cor do vestido da mãe que é rosa, ao gênero feminino.

Acredita-se que a autora da animação optou pela composição de personagens e de cenário com traços simples, apresentando os desenhos em duas dimensões (2D), mas que possivelmente utilizou a animação digital, ou seja, o computador como suporte para a produção das imagens digitais.

A narrativa apresenta uma situação inicial colocada pelo Prof. Lecré, que aborda a respeito dos cuidados que o planeta Terra precisa e o que nós, seres humanos, necessitamos para sobreviver. O Prof. Lecré apresenta o conceito de ecossistema como "o convívio em harmonia de todas as formas de vida sobre o planeta, uma influindo e 
dependendo da outra". Nesse momento, na imagem exibida, aparece o globo terrestre e, em destaque nele, os carros em movimento e pássaros voando e, logo depois, o professor faz uso de analogia para comparar o castelo de cartas ao que ocorre no ecossistema: "se uma não resolver colaborar, o sistema balança até que desmorona".

Apesar de o conceito apresentado ser amplamente aceito, existem críticas relativas à ideia de equilíbrio. Alguns estudos inferem que este conceito atualmente não se sustenta em função do nível de degradação devido à interferência das ações antrópicas que resultam em alterações no ecossistema.

Por outra perspectiva, o homem considerado como o principal agente modificador desse ambiente também possui a capacidade e a criatividade para restabelecer o ambiente.

O Prof. Lecré aborda a rotina da família Tal para explicitar as atividades diárias que podem impactar no equilíbrio do ecossistema e, consequentemente, contribuir para as mudanças climáticas, por exemplo, o aquecimento global. Em um momento do desenho, o Prof. Lecré abre a janela e o sol fica piscando, fazendo referência ao aquecimento global e reforçando essa relação. Este tema apresenta uma relação entre três fatores: os raios solares, os gases poluentes e o efeito estufa. A cena apresentada pode reforçar a relação direta do sol com o aquecimento global e não com os fatores supracitados.

As atitudes humanas, como a produção de gases poluentes, o desperdício de água e papel, o desmatamento, a impermeabilização do solo, assim como os resíduos sólidos que são destacados de forma colorida, para mostrar a presença desses objetos nos aterros sanitários, são retratados como exemplos que fortalecem o aquecimento global. Além disso, as consequências do aquecimento global podem provocar "maluquices climáticas", nas palavras do Prof. Lecré, que são abordadas na narrativa como as secas, as enchentes e as doenças tropicais, como a malária e a dengue.

O mosquito transmissor da dengue Aedes Aegypti é apresentado com quatro patas em vez de seis e sem antenas. Esse tipo de equívoco é também encontrado em outros veículos de comunicação, como livros e materiais de divulgação científica. Esse tipo de erro pode ser um obstáculo à compreensão das características gerais que são usadas para classificar os insetos. Entende-se que o autor tenha liberdade na elaboração de uma obra, mas tratando-se de um vídeo educativo, isso não é aceitável.

Além da analogia da pirâmide de baralho, a rede de lanchonete frequentada pelo senhor Fulano de Tal é uma analogia a uma das maiores redes internacionais de fast 
food ao fazer alusão às cores e à logomarca (propositadamente colocada de forma inversa).

Outros exemplos que, a princípio, não tem um caráter negativo como a produção de alimentos (frutas, criação de gado ou frango) também é danosa ao meio ambiente. No entanto, tal fato não fica evidenciado.

Ao final do desenho, os membros da família Tal aparecem doentes e o Prof. Lecré apresenta soluções que contribuem para melhorar o ambiente e a própria saúde da família.

O título do desenho animado Меи соrрo, теи mundo relaciona a preservação do ecossistema às atitudes humanas, sendo estas determinantes para o cuidado não só com o meio ambiente, mas com a prevenção de doenças, demonstrando como as ações antrópicas influenciam no sistema ecológico como um todo, ou seja, nos ambientes naturais ou ambientes construídos.

Os exemplos didáticos retratados no cotidiano da família Tal referentes às atitudes humanas são identificados pelos alunos, por ocorrerem nas famílias brasileiras e serem comuns na vida real.

Vale ressaltar que a situação inicial colocada pelo Prof. Lecré das atitudes negativas da família Tal e, posteriormente, as sugestões apresentadas por ele são de conhecimento da população e que poderiam minimizar o problema, mas não alteram o âmago da questão, ou seja, para minimizar os danos provocados no meio ambiente são necessárias ações mais rigorosas e efetivas. O problema não estaria resolvido somente com as sugestões apresentadas pelo Prof. Lecré.

Vale lembrar que esses equívocos citados não inviabilizam o uso do referido desenho animado, desde que o professor tenha clareza e aproveite o erro para discutir o assunto com os alunos. 


\section{APÊNDICE C}

\section{TERMO DE CONSENTIMENTO LIVRE E ESCLARECIDO (Orientação para alunos)}

Meu nome é Luciana Carvalho Carrilho, sou licenciada em Biologia, professora da Secretaria de Educação do Distrito Federal e doutoranda do Programa de Pós Graduação em Educação da Universidade de Brasília onde desenvolvo a pesquisa: Trajetórias animadas na formação do pensamento conceitual no Ensino de Ciências, sob a orientação da professora doutora Maria Helena da Silva Carneiro. O principal objetivo dessa pesquisa é investigar o papel do desenho animado no processo de formação de conceito de um referido tema com os alunos do $5^{\circ}$ ano do Ensino Fundamental de uma escola pública do Distrito Federal. O estudo visa contribuir com as discussões sobre o processo de ensino e aprendizagem de conceito mediado pelo desenho animado. Os instrumentos utilizados envolvem o registro de dados por meio de gravação de voz (conversas individuais e coletivas) e registro de imagens (fotografia e filmagem) das atividades das aulas planejadas para a realização da pesquisa. Caso, os senhores pais ou responsáveis legais, estejam de acordo com a participação do(a) seu(a) filho(a), posso garantir que o nome do aluno será mantido em sigilo, assim como, as suas imagens, para efeito de futuras publicações dos resultados da pesquisa em eventos da área de Educação e Ensino de Ciências (congressos e/ou seminários) e para a publicação em revistas de caráter científico. As imagens produzidas, fotografias e filmagens, não serão utilizadas para fins comerciais ou publicitários. Coloco-me à disposição para qualquer dúvida ou esclarecimento que considere necessário em qualquer etapa da pesquisa. (Celular: (61) 9972-5964)

Diante do exposto, declaro que fui devidamente esclarecido (a) e concordo com a $\begin{array}{lllll}\text { participação do meu } & \text { (a) } & \text { (minha) }\end{array}$ (a): na

condição de aluno do $5^{\circ}$ ano na pesquisa no período compreendido entre 05/11/2014 à 20/12/2014 e para a publicação dos resultados.

Nome completo do pai/mãe ou responsável:

Brasília- DF, 03 de novembro de 2014

Assinatura dos pais ou responsável legal 


\section{APÊNDICE D}

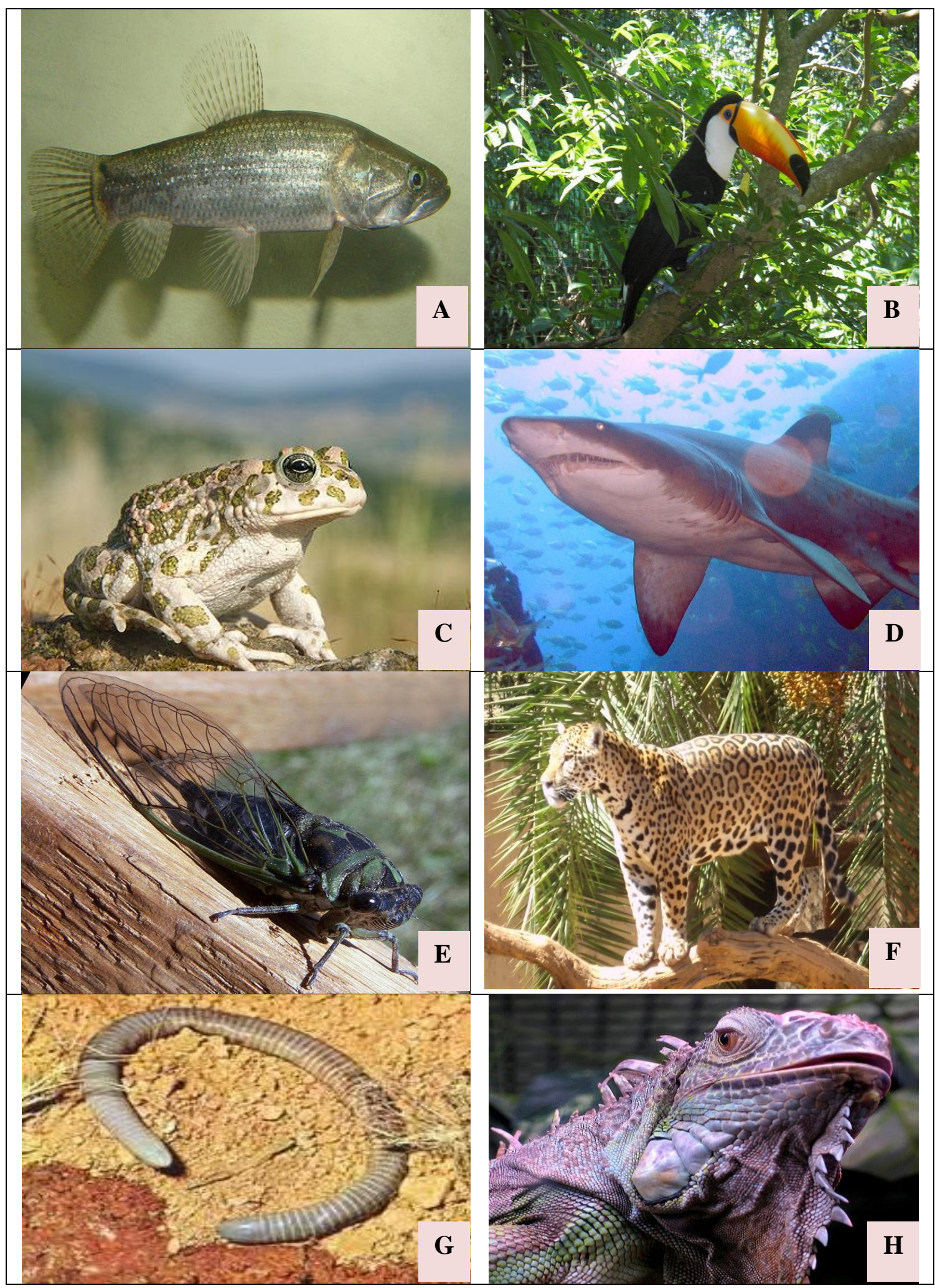

Fonte:http://commons. wikimedia.org. Acesso em: 30 out. 2014.

Legenda: A -Peixes; B - Aves; C -Anfíbios; D -Peixes; E - Insetos; F - Mamíferos; G-Anelídeos; e H Répteis. 


\section{APÊNDICE E - TRANSCRIÇÃO DO DESENHO ANIMADO AVENTURAS COM OS KRATTS}

Chamada (Música de abertura)

Com os animais incríveis eles vão se aventurar, A natureza e os seus mistérios, os kratts vão explorar, Com os seus amigos, os animais vão conhecer, Para salvá-los do perigo eles vão usar o seu poder, Seu poder animal é hora da aventura (2x), Aventuras com os Kratts, Velocidade, agilidade, voô de falcão, rugido de leão, Seu poder animal é hora da aventura, com os Kratts (2x) Aventura com os Kratts.

\section{Episódio: A cadeia alimentar (Parte 1 - 10'33”)}

Chris: Uhuh! Essas asas de falcão são incríveis para localizar animais na savana africana!

Martin: Com elas temos a visão dos pássaros!

Chris: Eih, olha uma raposa orelha de morcego!

Martin: Caramba, que orelhas grandes por isso se chama raposa orelha de morcego! A orelha é maior que a cara dela! Como um morcego!

Chris: É, elas se movem como radares! Hum, o que será que ela está ouvindo?

Áudio: som de radar

Martin: Hahaha! Duvido que seja isso!

Chris: É uma mensagem da Aviva! Ela diz: meninos, voltem para a tartaruga imediatamente, rápido! É urgente!

Martin: Hum, tudo bem Chris, mas só depois que eu ver o que essa raposinha vai aprontar!

Chris: Martin, ela diz que é urgente, quer dizer que é importante! Deve haver algum animal em perigo ou eles se miniaturizaram de novo, sem querer!

Martin: Ou o Jimmy perdeu o joystick (controle de vídeogame ou computador) de novo!

Chris: Haha! Temos que voltar logo pra lá! 
Martin: Vemos você depois raposa orelha de morcego! Uhuh para a tartaruga em velocidade máxima!

Chris e Martin: Uhuhuh!

Martin: Tem algum animal em perigo?

Chris: Algum mistério para desvendar?

Martin: Manda ver!

Chris e Martin: Ahm!

Aviva: Viu eu disse que chegariam aqui em menos de dois minutos!

Koki: Impressionante!

Chris: Muito bem! Qual é a emergência?

Aviva: A emergência é que vocês estão atrasados para o início do meu jogo!

Chris e Martin: Jogo?

Aviva: Também podem chamar de desafio! Eu estou montando uma teia alimentar para ver como a energia se move através do ecossistema africano! Eu sabia que vocês podiam me ajudar eu fiz um jogo com isso!

Martin: Ah, legal, adoramos jogos!

Chris: E desafios! Como se joga?

Aviva: Bom, ele se chama, encontre a teia alimentar!

Chris: Está em branco, Aviva!

Aviva: Por enquanto! Eu montarei aqui enquanto vocês a descobrem lá fora!

Martin: Teia alimentar é bem legal! Eu adoro teias alimentares!

Chris: É quem devora quem no ecossistema! Um animal devora uma coisa, então ele é devorado por outro, que é devorado por outro animal e vai subindo até chegar no animal que não serve de comida para ninguém!

Aviva: Exatamente! O jogo funciona assim: vocês precisam do traje dos animais e de todos os discos dos animais africanos, começam na base da cadeia alimentar e devem chegar ao topo o mais rápido possível!

Todos: Legal!

Aviva: Então vocês dois vão começar como...

Chris e Martin: Ahmmm!

Aviva: Folha de grama!

Chris e Martin: Ahh!

Aviva: Primeiro, vocês precisam achar um animal que come folha de grama!

Chris e Martin: Ehh! 
Aviva: E quando acharem, aí podem subirem na cadeia alimentar! Usem o super traje animais para se tornarem o animal que encontrarem!

Chris: Tá bem, quem é que vai primeiro?

Martin: Ah, eu já tô a caminho do topo, cara!

Aviva: Ah, mais uma coisa, só podem usar os animais para os quais eu já criei discos de poder!

Chris e Martin: Tudo bem, beleza!

Aviva: E enquanto fazem isso, vamos montar uma enorme teia alimentar no que encontrarem na savana! Estão prontos? Meninos? Meninos!

Koki: Acho que eles estão prontos!

Aviva: Ei esperem eu ... (não deu para entender o que ela disse)

Aviva: Pronto Chris?

Chris: Eu já nasci pronto!

Aviva: Pronto Martin?

Martin: Eu tô sim! Tô indo nessa! Boa sorte!

Aviva: Preparar, agoraaa!

Chris: Ahm, ah, eu nem consegui correr!

Martin: Presos no chão? Uma corrida de grama! Podemos esperar sentados!

Aviva: Divirtam-se meninos!

Jimmy Z: Pobre grama, a primeira da cadeia alimentar!

Koki: Pobre grama?

Jimmy Z: Aiii!

Koki: Desculpe Jimmy, mas não devia ter pena da grama! A base da cadeia alimentar é o lugar mais importante de todos!... É onde as plantas ficam, as produtoras fabricam sua própria comida a partir da energia do sol! É mais ou menos como os painéis captam a energia do sol para mover a tartaruga! Os animais não conseguem fazer isso, só as plantas!

Aviva: Muito bem! Primeiro nível da teia alimentar: plantas!

Jimmy Z: Mandem pra cá meninas!

Aviva: Toma a lichia!

Jimmy Z: Peguei!

Koki: Batata selvagem!

Aviva: Capim de rosa!

Koki: Junco!

Aviva: Flor de quiabo! 
Jimmy Z: Ehh!

Aviva: Acácia!

Jimmy Z: Ouuohh! Ahhh!

Koki: Ahm!

Jimmy Z: Bem, de uma coisa a gente sabe: existem muitos produtores!

Meninas: Hahaha!

Chris: Um monte de produtores vivem na savana africana! O problema é que eu preciso esperar que eles venham até mim!

Martin: Ah, não! Quem é que vai querer comer uma folha azul de grama? Ahm! Talvez eu precise ser um pouquinho menos óbvio! Venham herbívoros, tem uma grama verde bem apetitosa!

Chris: Folhas verdes! Como serei notado no meio de tudo isso? Ouh, agora sim! Lá vem os herbívoros! E que o jogo comece! Por aqui, por aqui! Calma, calma, esperem! Não, não vão embora! Elefantes, ah, eu acho que eles comem capim, não é? Eles usam a tromba como mãos para arrancarem um bocado de comida!

Áudio: som dos elefantes se alimentando

Chris: Ei trombinha! Sou eu, Chris! Vem cá só preciso tocar em você para passar para o próximo nível da teia alimentar! Eu sou uma...

Áudio: som de pisada

Chris: ...panqueca! Ahh, amassado por uma pata de elefante! Tudo bem que a grama está acostumada a ser pisada, mas eu nem consegui tocar neles! Herbívoros, voltem aqui!

Jimmy Z: Tá tudo pronto, Aviva!

Aviva: Certo, então os herbívoros comem as plantas?

Koki: Bichos como os rinocerontes, zebras, elefantes, galinhas da angola, girafas! E até mesmo as abelhas que comem os néctares das plantas! São todos herbívoros!

Jimmy: Uau, as plantas são incríveis! Elas alimentam todo mundo!

Aviva: É, muitos animais comem plantas e temos que colocar alguns deles na nossa teia alimentar! Jimmy!

Jimmy Z: Deixa comigo! Aiii, esse martelo continua me atacando!

Aviva: Continue se esforçando Jimmy porque temos que conectá-los! Então, os elefantes comem as gramas, as acácias e até as raízes!

Koki: Os elefantes também comem essas lichias selvagens!

Jimmy Z: Koki, o que está fazendo? 
Koki: O quê? Eu também gosto de lichias! Não só são os animais que gostam de frutas e vegetais, a gente também come!

Aviva, Jimmy e Koki: Ahm!

Koki: Eih, seu ladrão de lichias volte aqui! Bom, parece que tem outro animal que gosta dela!

Martin: Ah não, porque todos os herbívoros estão daquele outro lado da savana hoje? Ah, eu nunca vou chegar ao nível dos herbívoros se não tem nenhum ao meu alcance! Ai, hahaha, alguma coisa me mordeu! Ai, nossa, essas mandíbulas são muito fortes! Peraí, eu tô muito feliz em ver você! Um cupim serrador, ai! Legal, eu fui para o próximo nível, eu sou um herbívoro! Nossa que mandíbulas afiadas! Olha vamos fazer o que os herbívoros fazem!

Chris: Legal, o Martin passou para o próximo nível! Eu ainda tô preso! Ahm, entre os lábios de uma gazela de Thompson! Ah, eu ainda estou no jogo!

\section{Áudio:}

Chris: Uhruh, posso me mexer, posso correr! É, obrigada gazela, graças a você eu avancei na teia alimentar! Isso é ótimo, as gazelas são um dos herbívoros mais velozes da savana!Conseguimos alcançar uma velocidade de $80 \mathrm{~km}$ por hora a longas distâncias! Isso dá sede e as gazelas... das plantas e do capim! Hum, isso aqui tá seco demais! Ahm, perfeito, as gazelas gostam de capim baixo! Então, esperam que outros herbívoros comam a parte alta do capim para poder comer o mais gostoso! Hum, hum, ehhhr, ahhr! Será que eles acham isso aqui gostoso? Mas não estou mais com sede, estou pronto para subir na teia alimentar! Aha, eu sei exatamente quem eu preciso encontrar agora!

Aviva: Conseguiram, cada um num caminho diferente!

\section{Episódio - A cadeia alimentar (Parte 2 - 10'40")}

Aviva: De um caminho através da teia é uma cadeia alimentar! A cadeia alimentar do Martin vai do capim para o cupim!

Koki: E agora, o que acontece? Temos um pequeno herbívoro e um grande? Quem devora quem?

Aviva: Veremos! Vamos ficar de olho no pequeno Martin!

Koki: Você quis dizer cupim!

Aviva: Não, Martin! Lá está ele! 
Martin: Descendo! Ah, que bela casa você tem! Então, ele é diferente daqueles cupins que fazem aqueles montes! Vocês constroem túneis de ninhos subterrâneos! Ah, entendi, é aqui que guardam a comida, dentro dessas despensas de cupim! Legal, bom apetite, e se sobrar alguma coisa pode me chamar! Nossa, agora eu sei porque os cupins são os maiores herbívoros pequenos da África! Existem tantos que eles comem mais capim do que elefantes, zebras, gnus e todos os outros comedores de gramíneas juntos!

Chris: Como vão as coisas, mano?

Martin: Ah, tudo ótimo, Chris! Eu sou um cupim, eu ... a grama, construo ninhos, sou o herbívoro mais poderoso da savana!

Chris: Legal, agora precisa achar quem come cupins! Eu sou uma gazela e você se lembra da nossa amiga mancha? Que me perseguiu por toda a savana da última vez que viu uma gazela?

Martin: Ah, claro, como eu poderia esquecer!

Chris: Bem, ela vai me ajudar a avançar na teia alimentar! Deseje-me sorte!

Martin: Boa sorte!

Chris: Vem mancha! Que foi? Agora você não quer me perseguir? Vamos lá, guepardos adoram gazelas! Você pode me ajudar a chegar no próximo nível da teia alimentar! Aposto que não pega! Me mostra toda aquela velocidade que você usa para agarrar as gazelas da savana!

\section{Áudio: Guepardo se espreguiçando!}

Chris: Ah, você tá brincando! Logo agora você resolve tirar uma soneca!

Martin: Muito bem, agora eu estou procurando um animal que coma inseto! Muitos animais fazem isso, temos os ..., os javalis, os protelos, e...ahm, raposas orelhas de morcego! Ela ouviu alguma coisa! Então era isso desde o início! Cupins! Ah eu não acredito que ela consegue ouvir os cupins debaixo da terra! Pix ... ela ouve vocês mastigando! Ah, achei! Eu não disse que a gente ia se ver depois! Eu sou uma raposa orelha de morcego, tchu, tchu, tchá, tchá, ehh!

Aviva: Muito bem, Martin passou para a segunda ordem dos consumidores! Os animais que comem outros animais!

Koki: Ah, sim! Os predadores como raposas, cães selvagens, guepardos e leões!

Aviva: Tuinhas (não entendi a palavra) e até aranhas que comem outros insetos! Para resumir: se come um animal ele fica aqui em cima na teia alimentar!

Koki: Essa é a parte triste da teia alimentar! 
Aviva: Mas veja dessa forma, Koki! É como a natureza funciona: se os predadores desaparecessem, em pouco tempo haveria herbívoro demais! E logo não sobraria nenhuma planta, e aí ninguém sobreviveria! Tudo está em equilíbrio!

Koki: Acho que é por isso que a teia alimentar funciona bem, mas ainda é triste! Jimmy Z: Aiii!

Aviva e Koki: Hahaha!

Jimmy Z: Isso que é triste!

Chris: Ah, ah, eih Martin, saca só! Ai, ai, eu tô ferido, eu não consigo mais correr! Espero que um predador não me veja! Isso, meu truque está funcionando, predadores costumam atacar presas fracas ou feridas, são mais fáceis de pegar! Ah, estou tão ferido! Oh, ouh, funcionou mais com um predador diferente, um píton enorme se enroscou em mim! Píton são cobras constritoras, isso quer dizer que apertam as presas até elas não conseguirem mais respirar! Esse não era exatamente o plano! Mais vou aproveitar, dá pra apertar esse botãozinho pra mim, esse mesmo! Uhhuhh! Oba, sou um píton! Espera um pouquinho, nenhum animal come pítons adultos! Estou no topo da teia alimentar, uhuhu!

Aviva: Não tão rápido, Chris! Estamos checando uma coisa!

Chris: O quê?

Koki: Sim, está bem aqui, quase nunca acontece, mas grandes pítons adultos as vezes são caçados por leões e leopardos!

Chris: Tipo um daqueles ali?

Áudio: som de "chocalho" de cobra

Chris: Uau, tem que estar com muita fome para encarar uma píton! Bem, não foi dessa vez! Conseguir alimento pode ser uma tarefa perigosa para os predadores também! As presas se defendem e nem sempre conseguir uma refeição é fácil!

Aviva: Então é oficial, é raro, mas leões e leopardos podem caçar pítons quando estão desesperados!

Chris: Bem, é melhor eu me mandar e seguir a leoa! Preciso ir! Tchau aí, mancha!

Martin: É, eu sei que um leão comeria uma raposa orelha de morcego! Seria muito bom ficar de olho nas hienas malhadas também! Ah, se eu conseguisse achar uma delas! Hahaha, eu sei que você não tem nada com isso, mas tem que terminar minha cadeia alimentar!

Áudio: Som de águia 
Martin: Ahm? Águia marcial! Uh, essa foi boa, a velha virada de costas, a defesa do chute e da mordida, um clássico dessa raposa! É, não é fácil ser um animal com tantos predadores querendo te pegar! Ah, não! Um píton!

Chris: Oi Martin! Te peguei!

Martin: O quê? Chris! Hahaha, você é um píton, é?

Chris: Sou e sorte sua que não estou com fome porque nós pítons comemos raposas orelha de morcego!

Martin: Ufa! É bem cruel aqui fora!

Chris: Eu sei! Os animais precisam sempre ficar de olho nos predadores que estão tentando pegá-los!

Martin: Imagine se os humanos tivessem que viver assim todo dia!

Chris: Estamos quase lá, só falta achar mais um animal!

Martin: Vejo você lá no topo!

Chris: Te espero lá, mano!

Aviva: Tá quase acabando!

Koki: Uau, agora falta pouco!

Aviva: É, só sobraram poucos predadores como leões, leopardos, crocodilos, águias marciais!

Jimmy Z: Nossa dá até para se confundir com tantas teias!

Koki:É! Veja o Babuíno: ele come coisas daqui debaixo como capim, raízes e frutas e é devorado por animais lá de cima como leopardos, guepardos e pítons!

Aviva: É só seguir as linhas para ver quem devora quem!

Jimmy Z: Não, essas linhas me deixam tonto!

Aviva: Por isso que se chama teia alimentar! É incrível como todos esses animais estão conectados pelo que comem!

Koki: O Chris e o Martin estão quase conseguindo chegar ao topo!

Martin: Uhm, que animal comeria uma raposa? Uhm, eu conheço esse som e está vindo de lá! Leões!

Chris: Ahm, leões? Hahaha, filhotes brincalhões agora, grandes predadores depois! Ahra, um corpo esguio veio bem a calhar nesse jogo! Se eu conseguir encostar...

Martin: Tchu, tchá...

Chris: Ahm, Martin?

Martin: Tchu, tchá...Oba, eles me viram! Uh, ai, puxa eu tô quase alcançando! Zebras? 
Chris: Eles vão atacar a manada de zebras? Ei, esperem, aiihh! Aha, ouh, eih, vocês são bem fortinhos! Eu preciso apertar...au, cadê o botão? Haha, parem com isso, uhuh!

Martin: Uhuh, devagar, devagar! Uh, olá! Ahhh, ainda bem que eu posso contar com o poder de fuga das raposas! Chris, cadê você?

Chris: Eu virei brinquedinho de filhote de leão!

Martin: Eu tô fugindo de uma leoa!

Chris e Martin: Ativar poder do leão!

Aviva: Parabéns, meninos! Parece que os leões ganharam!

Koki: E não são aqueles que esão com traje de leão!

Chris: Ahra, opa, conseguimos!

Martin: Nós estamos no topo da teia alimentar!

Chris: A mamãe tá chamando! Tá na hora do jantar dos predadores do topo da teia alimentar e é assim a vida na natureza!

Aviva: Montamos a teia alimentar da savana africana!

Koki: Dos produtores!

Jimmy Z: Até chegar nos predadores do topo!

Koki: E olha que eu achava que os leões eram cruéis, mas na verdade estão só sobrevivendo e alimentando seus filhotes!

Chris: Isso mesmo, é assim que cada um desses animais desse quadro faz, criaturas comem outras criaturas! É como a natureza funciona! O leão que come a zebra não é mais cruel que uma zebra ou um cupim que come uma folha viva de capim! Todos são importantes para um ecossistema saudável! Aonde vocês vão?

Martin: Nós vamos fazer uma outra teia alimentar!

Chris: A gente se vê na América do Norte! Martin, vou começar como uma alga verde dos lagos!

Martin: Legal! Hahaha, e eu vou ser uma amora bem suculenta!

Aviva: Hahaha!

Chris: Como uma alga verde eu serei a base de ecossitema de um lago, cheio de animais interessantes!

Martin: E eu serei a amora mais incrível que já esteve na base de uma teia alimentar!

Chris e Martin: Hahahaha! 
APÊNDICE F

\begin{tabular}{|c|c|c|c|c|c|c|c|c|c|c|c|}
\hline $\begin{array}{l}\text { Seres vivos e não } \\
\text { vivos }\end{array}$ & AA1 & A2 & A3 & A4 & A5 & A6 & A7 & A8 & A9 & $\mathbf{A 1 0}$ & A11 \\
\hline 1.Ser humano & $\mathrm{I}$ & I & I & I & I & I & I & I & $\mathrm{I}$ & I & I \\
\hline 2.Árvore & $\mathrm{I}$ & $\mathrm{I}$ & $\mathrm{I}$ & $\mathrm{I}$ & $\mathrm{I}$ & $\mathrm{I}$ & $\mathrm{I}$ & $\mathrm{I}$ & $\mathrm{I}$ & $\mathrm{I}$ & $\mathrm{I}$ \\
\hline 3.Musgo & NI & $\mathrm{NI}$ & $\mathrm{NI}$ & NI & NI & $\mathrm{NI}$ & $\mathrm{NI}$ & NI & $\mathrm{NI}$ & NI & NI \\
\hline 4.Esponja & $\mathrm{NI}$ & $\mathrm{NI}$ & $\mathrm{NI}$ & $\mathrm{NI}$ & $\mathrm{NI}$ & $\mathrm{I}$ & $\mathrm{NI}$ & $\mathrm{I}$ & $\mathrm{NI}$ & $\mathrm{NI}$ & $\mathrm{NI}$ \\
\hline 5.Fungo (Cogumelo) & $\mathrm{I}$ & $\mathrm{I}$ & $\mathrm{I}$ & $\mathrm{I}$ & $\mathrm{I}$ & $\mathrm{I}$ & $\mathrm{I}$ & $\mathrm{I}$ & $\mathrm{I}$ & $\mathrm{I}$ & $\mathrm{NI}$ \\
\hline 6.Lagostim & $\mathrm{I}$ & $\mathrm{NI}$ & $\mathrm{NI}$ & $\mathrm{NI}$ & NI & $\mathrm{I}$ & $\mathrm{NI}$ & I & $\mathrm{NI}$ & NI & NI \\
\hline 7.Aranha & I & I & I & I & $\mathrm{I}$ & $\mathrm{I}$ & $\mathrm{I}$ & $\mathrm{I}$ & $\mathrm{I}$ & $\mathrm{I}$ & $\mathrm{I}$ \\
\hline 8.Girafas & $\mathrm{I}$ & $\mathrm{I}$ & $\mathrm{I}$ & $\mathrm{I}$ & $\mathrm{I}$ & $\mathrm{I}$ & $\mathrm{I}$ & $\mathrm{I}$ & $\mathrm{I}$ & $\mathrm{I}$ & $\mathrm{I}$ \\
\hline 9.Anta & $\mathrm{NI}$ & $\mathrm{NI}$ & $\mathrm{NI}$ & $\mathrm{NI}$ & $\mathrm{NI}$ & $\mathrm{I}$ & $\mathrm{NI}$ & $\mathrm{NI}$ & $\mathrm{NI}$ & $\mathrm{NI}$ & $\mathrm{NI}$ \\
\hline 10.Perereca & $\mathrm{NI}$ & $\mathrm{NI}$ & $\mathrm{NI}$ & NI & I & $\mathrm{NI}$ & $\mathrm{NI}$ & NI & $\mathrm{NI}$ & $\mathrm{I}$ & $\mathrm{NI}$ \\
\hline 11.Peixe abissal & $\mathrm{I}$ & $\mathrm{NI}$ & $\mathrm{NI}$ & $\mathrm{NI}$ & $\mathrm{NI}$ & $\mathrm{NI}$ & $\mathrm{I}$ & $\mathrm{I}$ & $\mathrm{I}$ & $\mathrm{I}$ & $\mathrm{NI}$ \\
\hline 12.Lesma & I & I & $\mathrm{I}$ & $\mathrm{NI}$ & I & $\mathrm{I}$ & $\mathrm{I}$ & $\mathrm{NI}$ & $\mathrm{NI}$ & $\mathrm{I}$ & $\mathrm{NI}$ \\
\hline 13.Tuiuiú & NI & $\mathrm{NI}$ & $\mathrm{NI}$ & NI & NI & $\mathrm{NI}$ & NI & NI & $\mathrm{NI}$ & $\mathrm{NI}$ & NI \\
\hline 14.Libélula & $\mathrm{NI}$ & $\mathrm{I}$ & $\mathrm{NI}$ & $\mathrm{NI}$ & $\mathrm{NI}$ & $\mathrm{I}$ & $\mathrm{I}$ & $\mathrm{NI}$ & $\mathrm{NI}$ & $\mathrm{NI}$ & $\mathrm{NI}$ \\
\hline 15.Anêmona & NI & $\mathrm{NI}$ & $\mathrm{NI}$ & NI & $\mathrm{NI}$ & $\mathrm{NI}$ & NI & NI & $\mathrm{NI}$ & NI & $\mathrm{NI}$ \\
\hline 16. Celular & I & I & I & I & I & I & I & I & I & I & I \\
\hline 17. Sol & $\mathrm{I}$ & $\mathrm{I}$ & $\mathrm{I}$ & $\mathrm{I}$ & $\mathrm{I}$ & $\mathrm{I}$ & $\mathrm{NI}$ & $\mathrm{I}$ & $\mathrm{NI}$ & $\mathrm{I}$ & $\mathrm{NI}$ \\
\hline 18. Shrek & $\mathrm{I}$ & $\mathrm{I}$ & $\mathrm{I}$ & $\mathrm{I}$ & $\mathrm{I}$ & $\mathrm{I}$ & $\mathrm{I}$ & $\mathrm{I}$ & $\mathrm{I}$ & $\mathrm{I}$ & $\mathrm{I}$ \\
\hline 19. Pedra & $\mathrm{I}$ & $\mathrm{I}$ & $\mathrm{I}$ & $\mathrm{NI}$ & $\mathrm{I}$ & $\mathrm{I}$ & $\mathrm{I}$ & $\mathrm{I}$ & $\mathrm{I}$ & $\mathrm{I}$ & $\mathrm{I}$ \\
\hline 20. água & $\mathrm{NI}$ & $\mathrm{NI}$ & $\mathrm{NI}$ & $\mathrm{NI}$ & $\mathrm{NI}$ & $\mathrm{NI}$ & $\mathrm{NI}$ & $\mathrm{NI}$ & $\mathrm{NI}$ & $\mathrm{NI}$ & $\mathrm{NI}$ \\
\hline 21. Bola & $\mathrm{I}$ & $\mathrm{I}$ & $\mathrm{I}$ & NI & I & $\mathrm{I}$ & $\mathrm{I}$ & $\mathrm{I}$ & $\mathrm{I}$ & $\mathrm{I}$ & $\mathrm{I}$ \\
\hline 22. Bactéria & NI & $\mathrm{NI}$ & $\mathrm{NI}$ & NI & NI & I & I & I & $\mathrm{NI}$ & NI & I \\
\hline 23. Pirarucu & $\mathrm{NI}$ & $\mathrm{NI}$ & $\mathrm{I}$ & $\mathrm{I}$ & $\mathrm{NI}$ & $\mathrm{I}$ & $\mathrm{I}$ & $\mathrm{I}$ & $\mathrm{I}$ & $\mathrm{I}$ & NI \\
\hline 24. Jaguatirica & $\mathrm{NI}$ & $\mathrm{NI}$ & $\mathrm{NI}$ & $\mathrm{NI}$ & $\mathrm{NI}$ & $\mathrm{NI}$ & $\mathrm{NI}$ & $\mathrm{NI}$ & $\mathrm{NI}$ & $\mathrm{NI}$ & $\mathrm{NI}$ \\
\hline 25.Algas & NI & $\mathrm{I}$ & $\mathrm{NI}$ & NI & $\mathrm{NI}$ & $\mathrm{I}$ & NI & NI & $\mathrm{I}$ & $\mathrm{NI}$ & NI \\
\hline $\begin{array}{l}\text { Total de seres } \\
\text { identificados por } \\
\text { aluno }\end{array}$ & 13 & 13 & 12 & 9 & 12 & 18 & 14 & 15 & 12 & 14 & 9 \\
\hline
\end{tabular}

*As células sombreadas do quadro significam que os alunos classificaram as imagens como seres não vivos. 
APÊNDICE G

\begin{tabular}{|c|c|c|c|c|c|c|c|c|c|c|c|}
\hline Seres vivos & A1 & A2 & A3 & A4 & A5 & A6 & A7 & A8 & A9 & A10 & A11 \\
\hline 1.Ser humano & criança & criança & garoto & meninos & pessoa & Menino & humano & pessoas & criança & menino & criança \\
\hline 2.Árvore & $\mathrm{I}$ & $\mathrm{I}$ & $\mathrm{I}$ & $\mathrm{I}$ & $\mathrm{I}$ & $\mathrm{I}$ & $\mathrm{I}$ & $\mathrm{I}$ & $\mathrm{I}$ & $\mathrm{I}$ & $\mathrm{I}$ \\
\hline 3.Musgo & árvore & NI & cachoeira & flor & floresta & NI & árvore & $\mathrm{NI}$ & mato & árvore & NI \\
\hline 4.Esponja & Coral & NI & $\mathrm{NI}$ & $\mathrm{NI}$ & estrela do mar & I & NI & I & NI & NI & NI \\
\hline 5.Fungo & cogumelo & cogumelo & cogumelo & cogumelo & cogumelo & cogumelo & cogumelo & cogumelo & cogumelo & cogumelo & $\mathrm{NI}$ \\
\hline 6.Lagostim & lagosta & camarão & camarão & escorpião & escorpião & lagosta & $\mathrm{NI}$ & inseto & escorpião & caranguejo & $\mathrm{NI}$ \\
\hline 7.Aranha & I & I & I & $\mathrm{I}$ & $\mathrm{I}$ & I & I & I & $\mathrm{I}$ & I & I \\
\hline 8.Girafas & $\mathrm{I}$ & $\mathrm{I}$ & $\mathrm{I}$ & $\mathrm{I}$ & $\mathrm{I}$ & $\mathrm{I}$ & $\mathrm{I}$ & $\mathrm{I}$ & $\mathrm{I}$ & $\mathrm{I}$ & $\mathrm{I}$ \\
\hline 9.Anta & hipopótamo & $\mathrm{NI}$ & $\mathrm{NI}$ & $\mathrm{NI}$ & $\mathrm{NI}$ & $\mathrm{I}$ & $\mathrm{NI}$ & coala & $\mathrm{NI}$ & $\mathrm{NI}$ & $\mathrm{NI}$ \\
\hline 10.Perereca & sapo & sapo & sapo & sapo & $\mathrm{I}$ & sapo & sapo & sapo & sapo & $\mathrm{I}$ & rã \\
\hline 11.Peixe abissal & $\mathrm{I}$ & piranha & piranha & piranha & piranha & piranha & peixe & peixe & peixe & peixe & piranha \\
\hline 12.Lesma & $\mathrm{I}$ & ganguji & $\mathrm{I}$ & caracol & $\mathrm{I}$ & $\mathrm{I}$ & $\mathrm{I}$ & caracol & $\mathrm{NI}$ & $\mathrm{I}$ & borboleta \\
\hline 13.Tuiuiú & ave & ganso & pássaro & $\mathrm{NI}$ & avião & garça & ave & pássaro & pássaro & pássaro & urubu \\
\hline 14.Libélula & $\begin{array}{l}\text { mosquito } \\
\text { da dengue }\end{array}$ & cambito & NI & $\begin{array}{c}\text { mosquitoda } \\
\text { dengue }\end{array}$ & NI & I & I & $\begin{array}{l}\text { mosquito } \\
\text { dadengue }\end{array}$ & NI & mosquito & NI \\
\hline 15.Anêmona & $\mathrm{NI}$ & $\begin{array}{c}\text { planta do } \\
\text { mar }\end{array}$ & $\begin{array}{c}\text { estrela do } \\
\text { mar }\end{array}$ & NI & $\begin{array}{c}\text { espinho do } \\
\text { mar }\end{array}$ & NI & $\mathrm{NI}$ & ouriço & NI & NI & $\mathrm{NI}$ \\
\hline 16. Celular & $\mathrm{I}$ & I & I & I & I & I & I & I & I & I & I \\
\hline 17. Sol & $\mathrm{I}$ & $\mathrm{I}$ & $\mathrm{I}$ & $\mathrm{I}$ & $\mathrm{I}$ & $\mathrm{I}$ & Lua & $\mathrm{I}$ & planeta & $\mathrm{I}$ & planeta \\
\hline 18. Shrek & $\mathrm{I}$ & $\mathrm{I}$ & $\mathrm{I}$ & $\mathrm{I}$ & $\mathrm{I}$ & $\mathrm{I}$ & $\mathrm{I}$ & $\mathrm{I}$ & $\mathrm{I}$ & $\mathrm{I}$ & $\mathrm{I}$ \\
\hline 19. Pedra & I & $\mathrm{I}$ & $\mathrm{I}$ & sol & $\mathrm{I}$ & rochas & $\mathrm{I}$ & $\mathrm{I}$ & $\mathrm{I}$ & $\mathrm{I}$ & $\mathrm{I}$ \\
\hline 20. água & céu & céu & céu & ar & parede & céu & céu & nada & papel & papel & linha \\
\hline 21. Bola & $\mathrm{I}$ & $\mathrm{I}$ & $\mathrm{I}$ & NI & $\mathrm{I}$ & $\mathrm{I}$ & $\mathrm{I}$ & $\mathrm{I}$ & $\mathrm{I}$ & $\mathrm{I}$ & $\mathrm{I}$ \\
\hline 22. Bactéria & $\mathrm{NI}$ & célula & célula & $\mathrm{NI}$ & $\mathrm{NI}$ & $\mathrm{I}$ & $\mathrm{I}$ & germe & NI & $\mathrm{NI}$ & micróbio \\
\hline 23. Pirarucu & baleia & peixe boi & $\mathrm{I}$ & $\mathrm{I}$ & baleia & $\mathrm{I}$ & I & $\mathrm{I}$ & I & I & baleia \\
\hline 24. Jaguatirica & onça & $\begin{array}{c}\text { filhote de } \\
\text { tigre }\end{array}$ & onça & onça & onça pequena & Onça & NI & $\begin{array}{l}\text { guepardo } \\
\text { filhote }\end{array}$ & gato & gato & gato \\
\hline 25.Algas & corais & I & flor & NI & NI & I & NI & $\begin{array}{l}\text { bicho do } \\
\text { mar }\end{array}$ & I & $\begin{array}{c}\text { planta do } \\
\text { mar }\end{array}$ & NI \\
\hline
\end{tabular}




\title{
APÊNDICE H
}

\section{Atividade 4 - Contação de história}

\begin{abstract}
Aluno A1
"Oi eu sou o professor Lecre eu vou contar para você o que acontece com o nosso mundo vamo começar por essa tal tal família ta dormindo o relógio toca e mais um dia de seviso o fulano que o pai liga o chuve e vai fazer a barba e ciclana que a mãe deixa o ferro ligado e vai procura o vestido e quando acha o vestido queima o dedo no ferro vai deixa o filho no carro e vai por seviso ciclano vai num carro fulana vai em outro carro a mãe vai pulado e pai vai pro outro lado que pega um trasito e solta muita fumaça e pului nosso mundo e a mãe vai vai escrevendo e nudar serto e vai ino e ate comular papel mais ela não sabe que o papel vei da arvore e as arvore que dar o nosso água lipa e depois e despeja a água suja que polui o meio ambiente o os lixo que eles jogam pode causa intupimento e pode causa inxente e o mosquito da dengue isso chama ecossistema Eu gostei muito por mostra o nosso mundo seno poluído" (192 palavras)
\end{abstract}

\section{Aluno A2}

"O professor Lecré contou uma historia de uma familia a família estava dormindo e acordou e ele contou a historia todos acordou para mais um dia e o seu ciclano foi toma banho e ligou o chuveiro e resoveu fazer a barba a ciclana foi passa roupa com cada um tem o seu carro e resoveu cada um sai para o serviso no seu carro e causou o ingarrafamento e a poluição da atismofera todos faziam tudo errado e o professo voutou o mundo para encinado como fazer tudo serto.

A minha opinião sobre o filme e uma lição de vida e insina a fazer tudo serto. (107)

\begin{abstract}
Aluno A3
"Era um homem com sua família qui fazia tudo errado gastava inergia quando era o almoço ele ia de carro para uma lanchonete era perto era so para puluir o mundo a mãe jogava lixo no chão o filho tinha bronquite quando a mãe dele levava para brinca ele brincava de terra e a mãe gulia suco de laranja um dia eles tiveram consciensia que estava fazendo tudo errado i nesse dia adiante comesaram fazer tudi certo i nunca mais eles fizeram isso.
\end{abstract}

Opinião: Eu ajei muito interessante ele esplica mundo" (91)

\section{Aluno A4}

"Meu nome é professor Lecré eu vou mostrar o mundo o que é ECO? Eco é Ecossistema eu vou mostrar a família de tal.

O pai e a mãe acordaro de manhã o pai barbeava a barba e deixava o chuveiro ligado, a mãe passava roupa e dobrava.

Ela feliz levava o filho no ônibus.

O pai ia em um carro e a mãe em outro. Na hora do lanche eles iam de carro.

Eles dois compraram só besteiras e jogaram no lugar que não era reciclável.

Opinião: Eu achei muito interessante porque fala sobre o meio ambiente é muito importante" (101)

\footnotetext{
Aluno A5

"Era uma vez uma família tudo começa quando o pai Fulano de Tal e a mãe Sicrana de Tal dormiam e o dispertador tocou e eles acordaram o pai tomava banho e fazia a barba e a mãe passava uma roupa só.
} 
A mãe levou uma picada de dengue o pai levou chuva e o bebê bronquite depois o Lecré voltou tudo e fez sair o tempo melhor.

Opinião: legal e interessante bem divertido.” (74)

\begin{abstract}
Aluno A6
"Hoje tive uma aula diferente, assistimos há um vídeo que se chama meu corpo meu mundo que fala sobre o gasto da energia e sobre a poluição mostrou isso em desenho animado.

Mostrou primeiro sobre o gasto da água que quando você vai tomar banho só pode ligar o chuveiro quando você foi entrar no chuveiro, e o gasto de energia e a fumaça dos carros. e

Eu acho que nós devemos andar mais a pé gastar menos gasolina, gastar menos água e energia." (84)
\end{abstract}

\begin{abstract}
Aluno A7
"Eu assisti um vídeo sobre o ecossistema, o vídeo mostra o que é ecossistema, é hoje eu aprendi que ecossistema é um sistema ecológico, sistema de enérgia, fala que tudo que fazemos, nós dependemos da enérgia.

E devemos andar menos de carro, usar mais transporte público, andar mais de pé, ou de bicicleta, evitar utilizar caixinhas de lanche e etc...

Gostei do vídeo porque tirou a dúvida da minha sala sobre o que é ecossistema.

É e mais engraçado do vídeo foi o professor Lecré." (85)
\end{abstract}

\title{
Aluno A8
} ira acabar.

"O mundo é um ser vivo que faz as pessoas viverem, nos temos que valorizar o mundo

Todo temos que colaborar, e como uma carta de baralio cair o castelo cai.

Todos nos conseguimos viver graças ao nosso planeta, claro que temos que pegar coisas da natureza para sobreviver mas temos que pegar e tomar cuidado." (58)

\begin{abstract}
AlunoA9
"Hoje eu comecei com uma aula diferente, a professora Luciana colocou um vídeo sobre a poluição do nosso mundo.

Tinha um personagem, o nome dele era Professor Lecré, e os outros personagens se chamava: fulano de tal, cicrana de tal, Beltraninho de tal, eles todo dia ião para o trabalho de carro, cada um no seu carro, isso só fazia fumaça e poluia a cidade, só calsando transito na cidade.

Ai o professor encinou como economiza energia e gasolina para uma melhoria na cidade.
\end{abstract}

Opinião: o filme e lega ele foi muito bom." (93)

\section{Aluno A10}

"Vimos um vídeo do mundo do Ecossistema. O vídeo se chamava meu corpo meu mundo, no comeso do vídeo apareceu um globo do planeta terra e de um homem, ele mostrou o dia a dia de uma família cujo o sobre nome era Tal. Papai: Fulano de Tal, Mãe: Siclana de Tal, Filhinho: Beutraninho de Tal. Eles disperdisão muta folha, lus, e etc. Mas depois o homem voutou o dia deles e pararam de desperdisa e foram uma familia feliz.

Gostei muito, mim ensinou muito a não desperdisar" (88)

\section{AlunoA11}

"Hoje eu assisti um filme bem legal e o nome dele é meu corpo meu mundo 
É o professor Lecré explicou o filme todim tipo que o pai não fosse no carro dele fosse com a mãe Sicrana de Tal pra que a mãe gastace menos gasolina e também pra não solta gás carbônico.

E a mãe tem que passar as roupas tudim de uma vez." (66) 
ANEXO
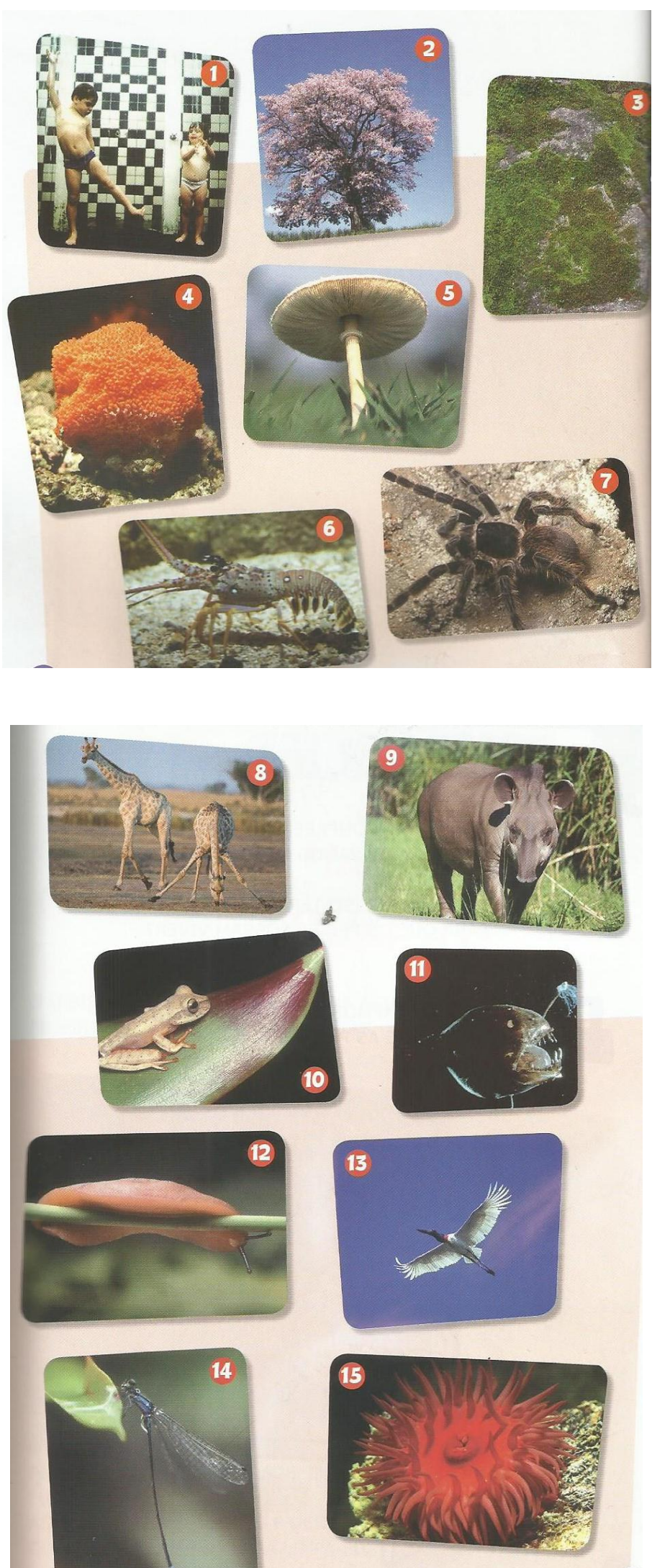